\title{
What the Shepherds Sing: \\ Local Identity in the Bucolic Idylls of Theocritus
}

\author{
Benjamin Beardsley Jasnow \\ Charlottesville, VA
}

MA University of Virginia, 2009

BA St. John's College, Annapolis, 2004

A Dissertation presented to the Graduate Faculty

of the University of Virginia in Candidacy for the Degree of

Doctor of Philosophy

Department of Classics

University of Virginia

August, 2014 


\section{Acknowledgements}

It is my great pleasure to thank those who have made this project possible. First and foremost, I owe an enormous and heartfelt debt of gratitude to my advisor, Jenny Strauss Clay. She has been a constant mentor and inspiration to me from my first days in graduate school, and I have benefited enormously from her depth of knowledge and literary sensibility in countless dissertation meetings, seminars and conversations over the years. Her wisdom, aid and encouragement have made my time at the University of Virginia a profoundly fulfilling experience. She has shown me what it means to be a scholar of literature. Coulter George has been a wonderful guide from the beginning of this project, not only for my chapter on dialect, for which his help was essential, but for the dissertation as a whole. He has been a constant fount of sound advice and insight, and his always perceptive feedback has shaped every page. I am extremely grateful to Tyler Jo Smith, who has been invaluable throughout. This dissertation is much better for her constant help and advice. Although she was technically the "outside reader" on this dissertation, that title is hardly sufficient. My great thanks as well to Jon Mikalson, who kindly joined my committee on short notice, and has always been a source of insight and a role model. It was for Jon Mikalson that I wrote my first seminar paper, on Pan in Theocritus. It seems fitting that the guide who led me through that first graduate project is also there at the finish.

A number of people have been generous enough to read portions of this dissertation as it developed. I am very grateful to Alexander Sens, not only for his very useful comments on an early draft of Chapter 1, but for introducing me to Theocritus in the first place. It was my great good fortune to attend his seminar on Hellenistic poetry at Georgetown. My great thanks to Richard Hunter for his helpful comments on an early draft of Chapter 1. My thanks as well to John Dillery, who read an early version of Chapter 1 and who has always been an inspiration. I am grateful to all the members of the Classics Dissertation Working Group for their feedback on an early draft of Chapter 1.

My time in the Department of Classics at the University of Virginia has been so enjoyable in large part because of my wonderful colleagues. I feel lucky to know everybody here, and I would like especially to thank Courtney Evans, Daniel Moore, Chris Caterine and Georgia Sermamoglou-Soulmaidi.

I am so thankful for my family. One of the great benefits of being in Charlottesville has been the chance to stay close to home. I will never be able to repay the kindness, encouragement and support of my parents, to whom I owe everything. I have loved living close enough to my brother Daniel to see him with some frequency, and I cherish our conversations. My uncle Richard has been a role model from the beginning, and it is in large part because of him that I wanted to become a scholar. I will always be grateful to you all.

The best thing about my time at the University of Virginia was meeting my wife, Gwen Nally. I am so grateful to you, Gwen, for being my friend, my inspiration, my constant conversational sparring partner, and the source of all my hope. I'll see you at home. 


\section{Table of Contents}

$\begin{array}{ll}\text { Introduction } & 1\end{array}$

$\begin{array}{ll}\text { Overview of Chapters } & 14\end{array}$

Chapter 1:

The Near East, Nearby: Daphnis and the Origin of Greek Bucolic Poetry

Chapter 2:

Idyll 1: Daphnis and the Poetics of Locale

Chapter 3:

Great Books / Wives' Tales: Polyphemus, the Idylls and Local Identity

Chapter 4:

Kunstsprache for the Common Man: Language and Identity in the Doric Idylls

Conclusion

Works Cited 


\section{Introduction}

The physical setting of the bucolic Idylls is about as different as could be from the Alexandrian cityscape to which much of Theocritus' audience must have been accustomed. Hellenistic Alexandria was a bustling port, a city full of people but home to none-everybody was from somewhere else, and there were lots of them; in Idyll 15 Gorgo and Praxinoa barely avoid being trodden underfoot by strangers. If Alexandria is the place where everyone has gone, the world of the bucolics feels like the place that everyone has left. But if you do come across one of the few others who are out in the pastures, they belong there, because their work ties them to the land. As often as not, you know their name: they may be strange, but they are not often strangers.

The dissonance between the realities of cosmopolitan existence and a remote, idealized countryside is one of the pervading features of the bucolic Idylls, which allows Theocritus to focus on a new narrative space: a local, popular point of view that is far removed from the urbane culture of the day, but at the center of its own sphere. This study investigates the techniques that Theocritus uses to create this local, popular vantage and endow it with cultural meaning, with a special focus on the Idylls that feature the landscape and mythology of Sicily (1, $6,11)$. But I would like to begin by discussing Idyll 7, which acts as a guide to Theocritus' literary audience, since it is about a self-professedly urbane, cosmopolitan man venturing into bucolic territory. The reader follows the poet-narrator of the Idyll, Simichidas, as he leaves the thriving Hellenistic port of Cos and goes beyond the city wall and into a rustic world, with its herders and agricultural festivals, and its way of life that persists more or less as it always has done, even as the nearby city becomes increasingly diverse and globalized, closely linked to the 
hub of Alexandria not only by trade, but by the personal affection of Ptolemy Philadelphus, who was born there.

Idyll 7 begins with our narrator Simichidas setting the scene for the story he is about to tell us (1-9):

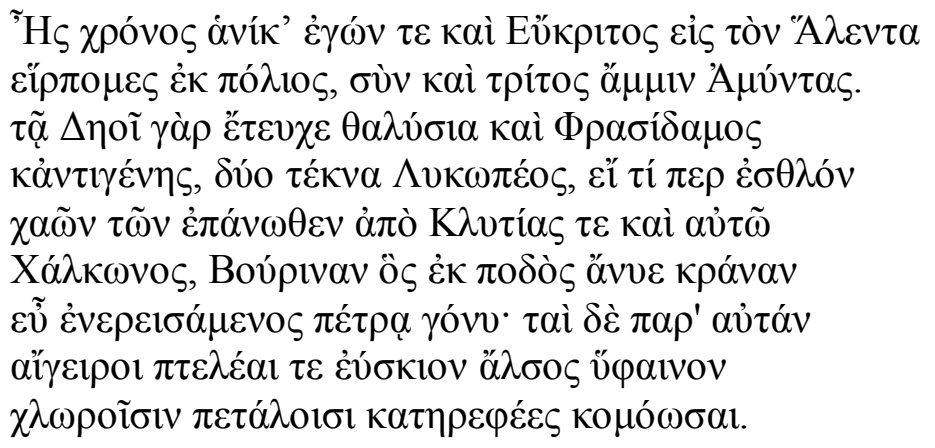

Once long ago, I and Eucritus strolled out from the city, down to Haleis; and Amuntas came too, our third. For they were giving first fruits to Deo [Demeter], Phrasidamus and Antigenes, Lycopeus' two boys, if aught noble remains of the good men of old, stock of Clytia and Chalcon himself, Chalcon who set the spring Bourina flowing with his foot, having thrust his knee well upon the rock. There poplars and elms wove a shrouded grove, bowing together with flourishing green leaves. ${ }^{1}$

Simichidas' journey away from the city ( $\left.\dot{\varepsilon} \kappa \pi \hat{\lambda} \lambda \iota_{0}, 2\right)$ to the private harvest festival is also a journey into the bucolic world, as Theocritus indicates by placing the special emphasis upon the the ancestors of Phrasidamus and Antigenes, the brothers who will host the celebration. Not only were Clytia and Chalcon members of the royal family that founded Cos, but Theocritus also appears to connect them to bucolic poetry. It was Chalcon who created the Bourina, a spring that serves as a metaphor for bucolic inspiration, as is clear not only from its etymology

(Bourina/boucolicos), but also by the similarity of its aition to that of Hippocrene, said to have been created when Pegasus struck the earth with his hoof. It is near Hippocrene that Callimachus situated Hesiod's meeting with the Muses. ${ }^{2}$ The setting of Bourina, as Simichidas describes it,

\footnotetext{
${ }^{1}$ Translations are my own unless marked otherwise.

${ }^{2}$ Call. fr. 2 Harder=4 Massimilla; Hunter (1999) 154. Cf. [Asclepiades] Anth. Pal. 9.64.
} 
sounds very much like a locus amoenus: a luxuriant grove of flourishing elms and poplars cast their shade upon the new spring. By emphasizing that the family of his hosts was connected from an early date to the bucolic world, Simichidas also implicitly connects the destination of his country walk with bucolic poetry. The narrator's journey away from the city, through the countryside to the Thalysia is a passage into an old pastoral world. ${ }^{3}$

What happens next very much fulfils these bucolic expectations. As Simichidas and his friends make their way through the deserted backcountry of Cos, they encounter a goatherd named Lycidas, whose reputation for skill at the syrinx is already known to Simichidas (27-29). Yet our city-dwelling narrator is strangely unintimidated. After all, Simichidas is himself a poet, as he proves by dropping the names of two fashionable Hellenistic luminaries, Asclepiades and Philitas and bragging about his own poetic skill (37-41). What follows is a familiar scene from elsewhere in the bucolic Idylls, in which the two men exchange songs of a suitably (though not purely) pastoral character (52-127). After the singing is done, Lycidas bestows his staff upon Simichidas, in a scene that reimagines the Hesiodic Dichterweihe for a bucolic context (128$129){ }^{4}$

Now the two bucolic singers, the one of longstanding repute, the other just now confirmed as such, part ways. Simichidas heads to the home of Phrasidamus and Antigenes to celebrate the Thalysia. It is here, at the home of these men of the old Coan line with their familial connection to the world of bucolic, that Idyll 7 reaches its climax. Simichidas finds himself immersed in a dizzying world of rustic pleasures (128-147):

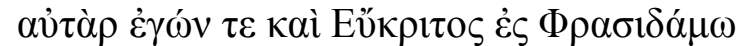

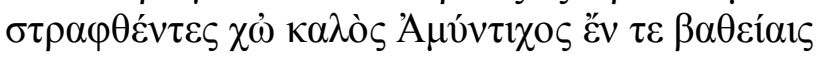

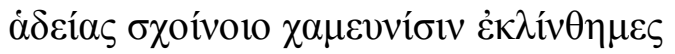

\footnotetext{
${ }^{3}$ On the connection of Phrasidamus and Antigenes to early Coan royalty, see Hunter (1999) 153 and Sherwin-White (1978) 49. On the bucolic connotations of the name Bourina, see Hunter (1999) 154 and Segal (1981) 127.

${ }^{4}$ On the reworking of the Hesiodic scene, see Hunter (1999) 149.
} 


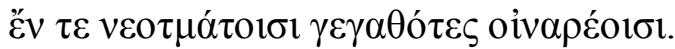

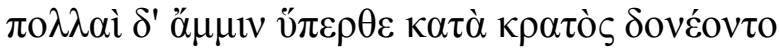

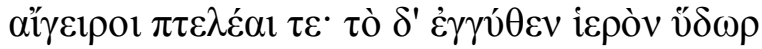

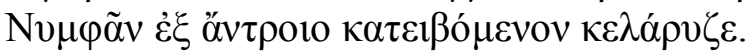

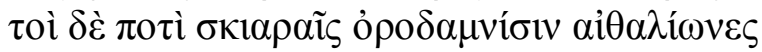

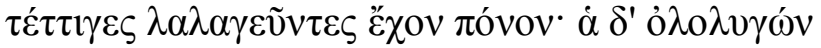

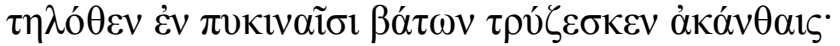

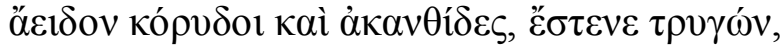

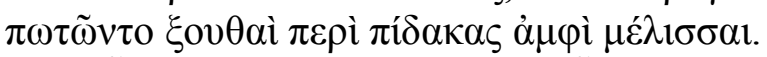

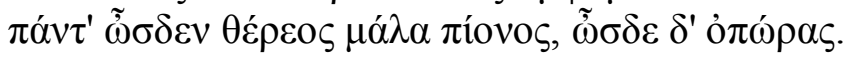

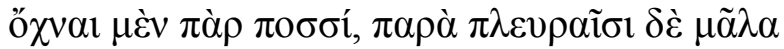

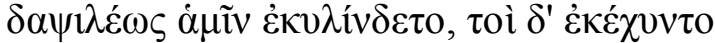

о̋

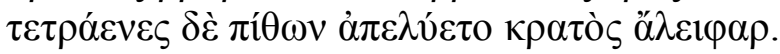

But I and Eucritus turned to the house of Phrasidamus, we and lovely Amyntas, and we reclined deep in pallets of fragrant rush, rejoicing in leaves fresh cut from the vine. The elms and poplars were shaking, bowing down above our heads; for there murmured, close at hand, sacred water, gushing from the cave of the Nymphs. The dusky cicadas, there, in the shade of the saplings, chirped their suffering. And afar the nightingale cried from the berry-bramble thicket. The lark and the gold-finch were singing, a dove was groaning, tawny bees went buzzing round the fountains. All smelled deeply of the harvest season. It smelled of the fruiting. Pears by our feet, by our sides were the apples. They rolled in abundance beside us. Young sprays strained down to earth, streaming with plums. And the four year seal was cracked from the mouth of the cask.

Just a few moments prior to this dazzling description of the natural and agricultural world, Lycidas had imagined in his song a rustic celebration in a locus amoenus very much like the one that now takes place (63-89). Simichidas' experience in the real world of Idyll 7 is the fulfilment of Lycidas' bucolic fantasy.

What I want to emphasize in this brief treatment of the seventh Idyll is the significance of Simichidas' journey into the countryside as a symbol for the new poetic mode of bucolic. The narrator's movement away from town and into the countryside situates the world of bucolic at a physical distance from the more urban world of Cos. While this programmatic journey clearly symbolizes the tension between town and country that is ever-present in Theocritus' pastoral world, this study will contend that another opposition is fundamental to the interpretation of the 
bucolic Idylls: that between an elite, globalized cosmopolitan culture and a local identity rooted in popular culture.

That the physical distance between Simichidas and the city in Idyll 7 embodies these themes becomes clear when we consider the social context of Hellenistic Cos. The population of the island had been spread out among several centers until the foundation of Cos city in 366 BC concentrated the population anew at a harbor on the north-eastern shore. ${ }^{5}$ Whereas the chief drivers of the island economy had been fishing and agriculture until this point, the new settlement facilitated the development of a thriving Coan trade. What had been a primarily agricultural community now exported its goods, such as wine, amphorae and perfume, to a wide array of places around the Mediterranean. The city grew wealthy from this trade and the accompanying harbor fees during relative stability of the third and second centuries $\mathrm{BC} .{ }^{6}$ Most importantly, Cos had especially close ties to Alexandria. This relatoinship was fostered not only by the ease of trade and communication between the two ports, but by the special favor bestowed upon the island by Ptolemy Philadelphus, who was born there. ${ }^{7}$ The close relationship between Cos and Alexandria was more than economic; it was cultural. The Coan poet Philetas was the tutor of Ptolemy Philadelphus; doctors and literary figures from Cos were drawn to Alexandria with great regularity, so much so that Coan medical men are hardly attested in the service of any other Hellenistic court. Sherwin-White has noted "the Ptolemies' effective monopolization of Coan talent in the third century." ${ }^{8}$ In short, Cos was a busy and well-connected port town, with strong trade and cultural connections to other cities around the increasingly globalized Mediterranean, especially Alexandria.

\footnotetext{
${ }^{5}$ Sherwin-White (1978) 63, 225. Sherwin-White remains the most important source on the history of Cos. See also Höghammar (2004).

${ }^{6}$ Sherwin-White (1978) 224-245, esp. 226-227.

${ }^{7}$ Hunter (2003) ad 58-76; Sherwin-White (1978) 90-108, 226.

${ }^{8}$ Sherwin-White (1978) 102-105, quote from 104.
} 
The city of Cos, however, is not the subject of Idyll 7. Although Simichidas sets out from this bustling port on his way to the Thalysia, the poem depicts a culture at a remove from the cosmopolitanism of the town. In fact, the dramatization of the physical voyage from the city of Cos is itself one of the most prominent features of the poem. The unexpected countrified taste of the city-dweller Simichidas is a source of humor as he simultaneously professes his cosmopolitan literary tastes and proclaims to be a real bucolic poet, who crafted his song up in the mountains (7.92). The duality of Simichidas is an emblem of the double nature at the heart of bucolic poetry, which professes to draw upon a rustic cultural sub-stratum even as it inaugurates an urbane new poetic mode. ${ }^{9}$

This poetic duality mirrors the real cultural transitions of the Alexandrian era in which Idyll 7 takes place. Even as Cos was enriched by its newfound interconnectivity with the rest of the Hellenistic world, the old mode of agricultural existence continued on the island much as it had before. ${ }^{10}$ Simichidas' trip away from the polis of Cos is a trip into this older mode of existence. The depiction of the physical journey enacts a poetic voyage away from the contemporary cosmopolitan culture, and into a local, rustic world that persists in relative isolation, engaging in traditions of local significance, far from the well-connected world of the city. The harvest-festival to which Simichidas travels is a private affair, on the land of a family connected to the earliest foundations of Cos. The goddess Demeter, whom the festival honors, was of great local importance, the subject of local folklore and literary activity (the Demeter of Philitas). ${ }^{11}$ On the way to this festival Simichidas engages in an artistic exchange, but not in a

\footnotetext{
${ }^{9}$ On the irony of Simichidas' pose, see Fantuzzi and Hunter (2004) 134-138; Hunter (1999) 148.

${ }^{10}$ Sherwin-White (1978) 64, 227.

${ }^{11}$ Sherwin-White (1978) 305-312. The Demeter of the Coan Philitas was prominent enough to have made it into the prologue to Callimachus' Aetia (fr. 1 Harder). On the Demeter see Spanoudakis (2002) 87-92, with Sens (2003).
} 
royal court or at a public festival; it is, instead, an ostensibly private interaction between two men in the middle of the countryside, one of whom is a goatherd with a gift for music.

These divisions that $I d y l l 7$ enacts — cosmopolitan port vs. rustic isolation, literary poet vs. popular singer - are not without difficulties. The very act of traveling from the city into the agricultural backcountry of Cos demonstrates that the two realms can be mediated. Moreover, the songs exchanged in Idyll 7 are not naively rustic or slavish imitations of actual pastoral worksongs, as we might have expected them to be. The performances of both Simichidas and Lycidas are replete with complex literary references. ${ }^{12}$ But even taking these complicating features of the poem into account, Idyll 7 clearly dramatizes the cultural divisions between cosmopolitan and local, literary and sub-literary.

From the point of view of an Alexandrian literary audience, Simichidas is every reader. Almost everyone who sets out to read the bucolic Idylls will be struck by the cultural divide between the rapidly globalizing Alexandrian culture of their daily life, and the idealized rustic isolation of the Idylls. But it is also Idyll 7 that most strikingly dramatizes the bridging of this gulf: Simichidas' journey from cosmopolitan port into the bucolic world of Lycidas and the locus amoenus of the Thalysia is emblematic not only of the creation of the bucolic mode by Theocritus, himself a cosmopolitan poet, but the imagined access into that world by Theocritus' cosmopolitan audience.

As this contextualized reading of Idyll 7 illustrates, and as this dissertation will demonstrate in fuller detail, Theocritus' opposition of cosmopolitanism to local and popular culture is a response to the historical conditions in which the bucolic Idylls were composed. To be more precise, the interest in depicting a local culture at odds with a broader, cosmopolitan culture is characteristic of periods of globalization, as Tim Whitmarsh has noted:

\footnotetext{
${ }^{12}$ For a survey of the allusions in the songs of Lycidas and Simichidas, see Hunter (1996) 22-28.
} 
The idea of the local is, after all, obviously created by supralocal perspectives. A people living in isolation on an island would not think of themselves as 'local' in fact, they would be much more likely to think of themselves as the blessed possessors of the cosmos. It is only when the missionary, anthropologist or oil company arrived that they would begin to view themselves, through the eyes of the outside world, as local. It follows, at least as a working hypothesis, that a phase of rapid globalization will also see an intensification of consciousness of localism; and perhaps also an increased awareness of, even questioning of, the power dynamics between the local and non-local. ${ }^{13}$

Although Whitmarsh makes this remark in a volume of studies on Greek microidentities during the Roman Imperial period, it applies just as well to the Hellenistic age, which was also an era of rapid globalization, witness to increasingly ecumenical, Pan-Hellenic culture. ${ }^{14}$ The koineizing tendencies of the late classical and Hellenistic age may be seen for instance in the transformation of tragedy from a type of play produced in the narrow context of the Athenian Dionysia to a genre embraced by the Greek world at large. By a similar process Old Comedy, with its local injokes and political jabs, is transformed into the broadly applicable comedy of manners familiar from Menander. "Finding what is koinon becomes a broadly shared intellectual project through the fourth century into the Hellenistic period, and thus the very sense of the koinon changes fundamentally.",15

It is in this context of cultural koineization, when the traditional genres are part of a cultural fabric knitting together a now expansive Greek world by means of a shared literary heritage, that Theocritus invents bucolic as a totally new poetic mode, one that ostentatiously links itself to local and popular culture. This invention is not without irony: Theocritus is a literary poet, as scholarly and clever as any in Alexandria, and yet bucolic makes much of its ties to isolated back-country locales and sub-literary characters. It would be a mistake, however, to

\footnotetext{
${ }^{13}$ Whitmarsh (2010) 2, who cites Appadurai (1990); Hannerz (1990).

${ }^{14}$ Whitmarsh (2010) 8-9.

${ }^{15}$ Goldhill (2010) 48-49, quote from 49. Goldhill also cites Gruen (1984); Green (1990) ; Green (1993); Clarke (2008) 245-251.
} 
deny that local and popular cultures are a central focus of the bucolic Idylls simply because they also betray a knowing awareness of more cosmopolitan, translocal culture. Such ironies are inherent to any profession of local identity: the "local" can only be defined in contrast to a larger culture in opposition to it. ${ }^{16}$ This local vs. supralocal opposition is quite clearly at work in Idyll 7, where the city of Cos, with its ties to the larger Hellenistic sphere, is opposed to an encounter with a singing goatherd and an isolated, private, local festival in the Coan countryside. The seventh Idyll puts local identity and popular culture into sharp relief by consciously opposing these categories to Simichidas' self-professed cosmopolitanism. The same opposition is at work in the bucolic Idylls as a whole, which seek to create and preserve a sense of Doric Sicilian and Magna Graecian identity in response to the increasing pressures of Alexandrian cosmopolitanism and the koineization of the Greek language.

This dissertation will focus in particular on Theocritus' engagement with Doric Sicilian local and popular identity. There are good reasons for this. First of all, the main mythological figures of the bucolic Idylls are Daphnis and the Cyclops Polyphemus, both of whom have strong ties to Sicily. An investigation of the main mythological motifs of the bucolic Idylls, therefore, is also an investigation of Sicilian local identity. More importantly, the programmatic first Idyll, which depicts the death of Daphnis, who was simultaneously the legendary first singer and first subject of Greek bucolic poetry, takes place on Sicily and repeatedly proclaims its connection to the island. This is so much the case that poets subsequent to Theocritus would come to identity Greek bucolic with Sicily itself. ${ }^{17}$ In addition, Sicily was the most important locus of Doric

\footnotetext{
${ }^{16}$ Whitmarsh (2010) 2-4; Goldhill (2010) 48.

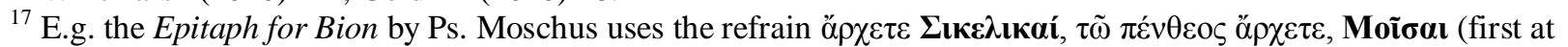

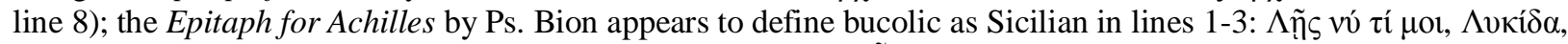

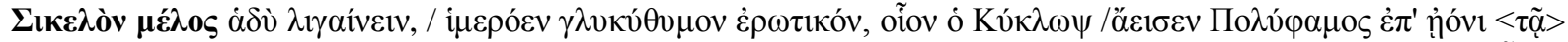

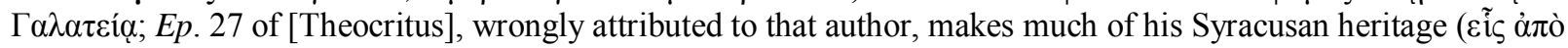

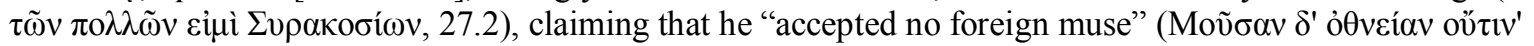
$\dot{\varepsilon} \varphi \varepsilon \lambda \kappa v \sigma \alpha ́ \alpha \alpha \nu)$.
} 
Magna Graecian culture. It thus acts as the pre-eminent representative of Doric Magna Graecia as a whole. ${ }^{18}$

Since this dissertation argues that Theocritus uses the bucolic Idylls to create and preserve aspects of Doric Sicilian local identity, frequently rooted in popular culture, and that he draws attention to this process, it will be useful to briefly define each of these terms, before summarizing the arguments of each chapter. Let us begin with the extremely difficult question of popular culture. It is not possible to read the bucolic Idylls without noting the radical combination of dactylic hexameter, the most stately of poetic meters, with themes and characters from the pastoral world. Theocritus' foregrounding of pastoral characters, not merely in the service of comedy or to mention them in passing, but to make them the centerpiece of an elaborate literary world, is a novel departure from previous literature. ${ }^{19}$ Of course, this shift of authorial focus does not make the bucolic Idylls 'popular literature.' Theocritus was a literary poet and any depiction of popular culture or people of low social status in his work are necessarily filtered through an elite perspective: popular culture in the Idylls is a construct of the author. And yet even the effort to construct a fictional, idealized 'everyday' bucolic world is to valorize to some extent the concept of the popular: to depict a shepherd working and singing in dactylic hexameter is to equate the subject matter of the bucolic world and the subject matter of epic, even if that equation is sometimes ironic.

Although the pastoral world of the Idylls is a literary construct, it is nonetheless appropriate to wonder to what extent the bucolics draw upon actual popular material. Indeed, a number of scholars have catalogued the sub-literary elements, drawn from reality, that help

\footnotetext{
${ }^{18}$ Cf. Willi (2012) 283.

${ }^{19}$ The arguments in this paragraph largely follow Fantuzzi and Hunter (2004) 133-148.
} 
create the quasi-realistic texture of the bucolics. ${ }^{20}$ This dissertation will not catalogue every proverb, superstition or folk custom that Theocritus seems to utilize (although attention to such details is certainly important to the interpretation of his poetry); rather, it aims to demonstrate that some of the most central and programmatic features of Greek bucolic poetry are meaningfully connected to Doric, especially Sicilian, popular culture: namely Daphnis, the Cyclops Polyphemus and the dialect of the bucolic Idylls. The creation of a completely fictional world is a very different act than the fictionalization of subjects drawn from the real world, with special connections to a specific locale. While we must regard Theocritus' use of popular culture as part of a literary construct, mediated by an elite point of view, it is of the utmost importance to discover whether the popular subjects he chooses were connected to the real world.

In determining what constitutes popular culture, I follow Leslie Kurke and Pavlos Avlamis, who have embraced the notion of "great" and "little" traditions, borrowed from scholarship on early modern Europe ${ }^{21}$ By this account "great" traditions are those accessible only to a narrow swath of educated elites. The majority of people are excluded from the great tradition, either due to illiteracy or to a lack of access to institutions in which perpetuate that tradition. The little tradition, transmitted by more informal means, is open to all, including those with access to the great tradition. The definition of these categories should not be taken to mean that the great and little traditions are mutually exclusive. For example, Charles Perrault recorded a collection of fairy tales from the nurse of his son, which he adapted in a sophisticated tone for the court of Louis XIV. 'Mother Goose' thus went to court, even as the stories continued to circulate as part of the little tradition. Perrault's version of the tales, moreover, was later adapted

\footnotetext{
${ }^{20}$ Examples include Cipolla (1979); Horowski (1973); Petropoulos (1959); Merkelbach (1956); Caberghs (1944); Di Mino (1931).

${ }^{21}$ Kurke (2011) 7-8 and Avlamis (2010) 16-21, building on the work of Burke (1978) and Redfield (1956).
} 
into simplified prose for the purpose of distribution to the peasantry. ${ }^{22}$ As Leslie Kurke has noted, Hellenistic Alexandria appears to have produced a number of elite authors especially interested in investigating the little tradition, Theocritus among them. ${ }^{23}$ To avoid the pejorative overtones associated with those terms, however, I propose replacing "great" and "little" with "closed" and "open" respectively. Popular culture in this dissertation will refer to the open tradition.

It is clear from this discussion of closed and open traditions that the concept of popular culture in this dissertation overlaps to a great extent with that of local identity, since the topics to be investigated (Daphnis and the origins of bucolic poetry, Polyphemus, dialect) each have a close connection to Doric Magna Graecia, especially Sicily. Beyond this similarity of topics, popular culture and local identity are to a large extent inseparable in the bucolic Idylls. Any instance in which Theocritus broaches the idea of local identity is likely also to address issues related to popular culture, since the setting, characters, dialect and many of the themes of the bucolics belong to the open tradition or are intended to be perceived as such. More importantly, perhaps, the open tradition is a useful vehicle for the poet interested in local culture, because it projects the image of inclusivity. Since all are capable of participating in the open tradition, a poet who treats the popular culture of a particular region or ethnic identity may be perceived as treating the totality of that region. Although the study of the vernacular has at times been distorted in the service of romantic nationalism or biased social agendas, ${ }^{24}$ the portrayal of popular culture characteristic of a geographic area may nonetheless be one way of addressing regional identity.

\footnotetext{
${ }^{22}$ Kurke (2011) 9.

${ }^{23}$ Kurke (2011) 8 n.18.

${ }^{24}$ See Storey (2003) 1-15.
} 
Since this study concerns itself mainly with Doric and Sicilian Greek identity, it will be useful to briefly mention some recent scholarship that argues for the existence of such regional categories. Jonathan Hall has demonstrated the existence of a perceived Doric Greek ethnic identity, beginning in the archaic age and extending into the Roman era, based in myths of shared genealogy and common place of origin. One of Hall's central tenets is that identity is discursive, that is, it is something enacted by talking or writing about it. As such, Hall focuses mostly on myth, and avoids relying upon other elements that might be considered to contribute to a collective sense of identity, such as common dialect or styles of pottery. ${ }^{25}$ While Hall's demonstration of the existence of a Doric Greek identity is certainly convincing, the present study follows Carla Antonaccio and Andreas Willi in asserting that a wider range of cultural artifacts may allow us to reconstruct ancient identities, including dialect, which I will deal with in Chapter $4 .^{26}$

Although Sicily was colonized by groups of various Greek ethnicities, a particularly Sicilian identity also emerged on the island. Sicilian identity coexisted, on the one hand, with previously existing categories of Greek identity (like Doric), but was also defined in opposition to them. A sense of collective identity could serve to unite the diverse population of the island in times of crisis, as Hermocrates' speeches to the Sicilians in Thucydides demonstrate. The Sicilian identity emerged partly from a sense of shared geography, but also as a result of colonial Greek self-definition in response to encounters with native Sicilian peoples. At the same time that the new Sikelote identity was defined in opposition to native Siclian culture, it was also being influenced by it, resulting in what Antonaccio has called a "hybrid" identity. In addition,

\footnotetext{
${ }^{25}$ Hall (1997) 34-66.

${ }^{26}$ Antonaccio (2001) 115-116; Willi (2008) 1.1-1.4; cf. Willi (2012).
} 
Sicilians could define themselves in relation to mainland Greece, leading to an identity in opposition to non-colonial, mainland Greek culture. ${ }^{27}$

\section{Overview}

To demonstrate that Theocritus uses the bucolic Idylls to reflect upon and preserve regional Doric identity in the face of the literary canon and Alexandria's rising cultural domination and internationalization, I examine the historical, literary and linguistic underpinnings of Doric Sicilian identity in the bucolic Idylls.

Chapter 1 proposes that Greek bucolic poetry first arises in a Doric adaptation of Near Eastern cult. The most plausible origin theories have detected foreign influence in the bucolic Idylls, comparing Daphnis to a Near Eastern paredros, the male companion of a fertility goddess. But such theories fail to account for the insistence of the Idylls that Daphnis and bucolic are of Sicilian origin; nor has an adequate historical account been offered to explain how Near Eastern myth and cult may have influenced Doric Sicily. Drawing on archeological and mythological evidence, I show that 1) Daphnis originates in Sicilian popular festivals to Artemis, ultimately stemming from the cult of Artemis Ortheia at Sparta, which was influenced at an early date by myths about a Near Eastern paredros, and that 2) Ortheia's cult most likely travelled to Sicily with colonists from the vicinity of Sparta. This theory therefore places the genesis of bucolic in Sicilian local and popular culture: Daphnis is a figure of local significance, drawn from a popular religious context, and Idyll 1 is a statement of regional identity.

Chapter 2 investigates the interpretive value of this origin theory for the programmatic first $I d y l l$, from both a Near Eastern and a local perspective. Near Eastern parallels help explain

\footnotetext{
${ }^{27}$ On hybridity, see Antonaccio (2003). On Sicilian identity see Antonaccio (2001) and Willi (2008) 1.1-1.5 and passim.
} 
some puzzles of Idyll 1, like the pursuit of Daphnis by a female, his hostile exchange with Aphrodite, his death and subsequent lamentation. On the other hand, Daphnis' connection to popular Sicilian cult is the most important feature of the "poetics of locale" that Theocritus establishes in Idyll 1. While the ecphrasis of the cup, strongly indebted to Homer and Hesiod, is an emblem of Pan-Hellenic epic tradition, the song of Thyrsis takes a radically different perspective, dramatizing a live performance of local oral tradition, rooted in Sicilian popular cult and bearing the hallmarks of festival performance. Theocritus thus validates a local, sub-literary tradition by juxtaposing it to the cup, a symbol of the Pan-Hellenic canon.

Chapter 3 argues that Theocritus' treatment of the Cyclops Polyphemus, best known from Homer's Odyssey, is an occasion for the poet to reimagine the Pan-Hellenic literary canon in more local terms. Theocritus offers a decidedly sympathetic perspective on the monster, emphasizing that he and the Cyclops both come from Sicily (Idyll 11.7). Polyphemus is no longer the gluttonous, stupid, brutal ogre of Homer and previous authors, but a besotted lover, with an interest in poetry and philosophy. In Idyll 11, Theocritus re-appropriates a Pan-Hellenic figure for Sicily by reforming his character and putting him at the narrative and geographic center of his poetry.

Finally, chapter 4 suggests that the dialect of the bucolic Idylls, like Daphnis and the Cyclops, serves as a means of reflecting on local and popular Doric identity. Theocritus constructs an artificial literary language that nonetheless uses historical, unliterary, regional word-forms, often drawn from epichoric Doric dialects. By using such decidedly unliterary features, Theocritus' Doric Kunstsprache is strongly marked against previous and contemporary Doric poetry, as well as epic language and the increasingly standard Attic-Ionic koine. 


\section{Chapter 1: \\ The Near East, Nearby: Daphnis and the Origin of Greek Bucolic Poetry}

\section{INTRODUCTION}

The first Idyll by the Sicilian poet Theocritus presents a Sicilian shepherd named Thyrsis, who sings a song about the legendary Sicilian cow-herder Daphnis, who was supposedly the first singer of the Sicilian mode of bucolic poetry. The landscape and traditions of Sicily are as present and important as any of the characters of the Idyll. Daphnis is the keystone of the first Idyll's local ethic: when Daphnis goes to his death, all of Sicily mourns. To understand what bucolic is, to understand the nature of the poetic mode that Idyll 1 initiates, programmatically dramatizing the first occasion of bucolic song, we must understand Daphnis. Since he is a figure of local importance in a poem that constantly emphasizes its Sicilian character, a clear understanding of Daphnis' origins and his role in Sicilian culture is imperative to understanding not only the first $I d y l l$, but Theocritus' bucolic program as a whole. Yet no satisfactory theory exists of Daphnis' importance to Sicily and his significance to the genesis to bucolic poetry.

This chapter offers a theory of Daphnis' origins, which aims, in turn, to uncover the context in which Sicilian bucolic poetry first developed and to demonstrate that Idyll 1 and Theocritus' new poetic mode are inseparable from issues of Doric and Sicilian local and popular ethnic identity. Specifically, this chapter will reconcile, justify, and redefine two extant theories of bucolic's origins: one that understands Daphnis as a Near Eastern paredros, the other an ancient scholiastic tradition that locates bucolic's origins in popular festivals to the goddess Artemis. The union of these two nodes of scholarship will make it clear that the question of origins is essential to Theocritus' poetic project: only by unearthing the popular, cultic and ethnic background of Daphnis can we understand the extent to which Idyll 1 and the bucolics as a 
whole comment on Sicilian and Doric local and popular identity.

\section{DAPHNIS AND SICILY IN IDYLL 1}

Daphnis has an intimate connection to the landscape of Sicily: as he goes to his death, the Sicilian countryside itself joins in lamenting him. But Daphnis' connection with Sicily does not begin with Theocritus. The Sicilian historian Timaeus, who flourished in the late fourth or early third century B.C., records (via Parthenius Narr. Amat. 29) that Daphnis was Sicilian, as do Nymphodorus (Scholia in Theocritum 1.65-66a), Diodorus (4.84), Servius (ad Ecl. 5.20), and Aelian (VH 10.18). In his recounting of the Daphnis legend, Aelian also mentions that Stesichorus of Himera treated the suffering of Daphnis, and that he "began this type of lyric" 28

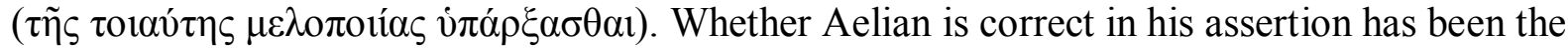
subject of some debate, but Hunter concludes as follows:

Doubts have been expressed about whether the famous Stesichorus of Himera, rather than a fourth-century namesake, really sang (or even mentioned in passing) the story of Daphnis, but there is no compelling reason to reject the traditional interpretation..., and the reference to the River Himeras at 7.75-Himera stands at its mouth on the north coast of Sicily — makes it not implausible that T[heocritus] associated the story with his great Sicilian forebear. ${ }^{29}$

Stesichorus flourished in the $6^{\text {th }}$ century. It is impossible to know what he knew of Daphnis or what type of verse he employed to sing about him. Nonetheless, it is plausible to assume that Stesichorus knew of and treated Daphnis in some way, even if our cowherd may not have been fully developed in the $6^{\text {th }}$ century, for reasons to be discussed later on. ${ }^{30}$

\footnotetext{
28 Trans. Hunter (1999) 65.

${ }^{29}$ Hunter (1999) 65.

${ }^{30}$ The ancient sources are not, however, in universal agreement as to Daphnis' origin. The summaries of Sositheus' satyr play "Daphnis or Lityerses," roughly contemporary with Theocritus, do not say whether that author made Daphnis Sicilian or otherwise. The play is set in Phrygia, but the plot makes clear that Daphnis is not originally from there (Athenaeus 10.415b; Servius ad Ecl. 8.68; Scholia in Theocritum Id. 8 argumentum and 93a, Id. 10 41d-e). Hermesianax, roughly contemporary with Theocritus, makes Daphnis the lover of Menalcas and sets their story on Euboea (Scholia ad Theoc. 8.53d), though the possibly post-Theocritean and spurious Id. 8 puts the same characters
} 
There are a number of anecdotes about Daphnis, most of them late, though several sources are contemporary with or prior to Theocritus. The version of the story which Parthenius recounts (Narr. Ama. 29), for instance, is attributed to the late 4th-early 3rd century Sicilian historian Timaeus. ${ }^{31}$ Nymphodorus is another roughly contemporary Sicilian author who discussed the Daphnis tradition in his Wonders of Sicily, though we find only a scrap of his account in the scholia to Theocritus. ${ }^{32}$ Despite the variety of sources from different periods, "the ancient tradition is fairly consistent." ${ }^{, 33}$ I will provide one account of Daphnis in full and point out certain important details repeated in multiple sources.

Diodorus' version (4.84) contains the largest concentration of relevant details, and his account is also consistent in its major points with the mainstream of tradition:

In the Heraean mountains [SE Sicily, inland from Syracuse], so the story goes, was born Daphnis, a son of Hermes and a nymph, and he, because of the bay ( $\delta \alpha \dot{\varphi} \varphi \eta \varsigma)$ which grew there in profusion, was called Daphnis. He was brought up by the nymphs, and possessed very many herds of cattle which he tended very carefully. For this reason he earned the name 'Boukolos'. He was a naturally

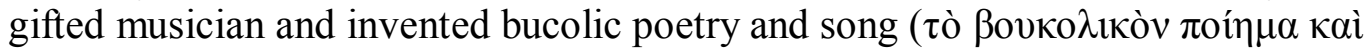
$\mu \varepsilon \dot{\lambda} \mathrm{o})$, which persists throughout Sicily to the present day. The story is that Daphnis hunted with Artemis and found favour with the goddess, and that he delighted her exceedingly with his syrinx playing and bucolic singing ( $\beta о v \kappa о \lambda 1 \kappa \tilde{\varsigma} \mu \varepsilon \lambda \omega \delta i ́ \alpha \varsigma)$. They say that one of the nymphs fell in love with him and warned him that, if he slept with another woman, he would lose his sight. A king's daughter made him drunk and he slept with her, whereupon he was blinded in accordance with the nymph's warning. (translation Hunter [1999] 64-65)

on Sicily (56). Gow himself admits the possibility that Idyll 8 may be an early work of Theocritus, however, which would make the poem an important Sicilian counter-example to the Euboean version of Hermesianax (Gow [1952] 2.171). Hundreds of years after Theocritus, Ovid (Met. 4.276) associates Daphnis with Mount Ida, though this may be a clever reference to the syncretization of Daphnis with figures like Attis and Anchises. Anchises' connection to Mount Ida in the Troad is apparent: he herds his cattle there before his encounter with Aphrodite (HHA 54; cf. Theoc. $I d$. 1.105). But there were two Mount Idas, one in the Troad, and one on Crete. Both were sacred to Cybele/Rhea, Attis' mistress. Longus, writing at a point even further removed from the main stream of the Daphnis tradition, locates Daphnis on Lesbos, perhaps the novelist's home as well. What is clear, despite Daphnis' occasional removal from the isle of Sicily, is that Theocritus and most of the early sources, probably including Stesichorus, make him an explicitly Sicilian character. Even if there were alternate treatments, Daphnis was conventionally Sicilian according to the tradition that Theocritus follows and that predates the poet.

${ }^{31}$ On which see Hunter (1999) 64.

${ }^{32}$ Scholia in Theocritum 1.65-66a (Wendel).

${ }^{33}$ Hunter (1999) 64. 
This version agrees with that of Timaeus/Parthenius (Narr. Ama. 29) and Aelian (VH 10.8) in the following features: Daphnis is a Sicilian cowherd with whom a nymph falls in love. She enjoins him not to sleep with anyone else, but Daphnis, having been made drunk, is seduced by a mortal woman, a Sicilian princess. As a punishment for disobeying the nymph, Daphnis is blinded. All three accounts associate Daphnis with the origin of bucolic song, but only Timaeus/Parthenius and Diodorus make him a musician. Like Diodorus, Aelian etymologizes the name of Daphnis, claiming that he was exposed in a laurel bush. Parthenius/Timaeus and Aelian both highlight Daphnis' beauty. Sositheus, via the scholia to $I d$. 8.93 , reports a similar love-triangle between a nymph, Daphnis, and an unspecified woman. However, in addition to mentioning that Daphnis becomes blind in some accounts, the scholiast claims that Daphnis died of grief for the nymph, who had left him when he slept with the other woman. Of all these accounts, Diodorus alone associates Daphnis with Artemis, a point which will be of great importance later on.

There is also evidence that Daphnis was the object of cult worship on Sicily. Virgil, in his fifth Eclogue, depicts Daphnis as a divinity (5.20ff). Servius, in commenting on the divinity of Daphnis in Eclogue 5, explains (ad 5.20) that Mercury (Hermes) took Daphnis up among the gods, and at the place of his apotheosis a fountain appeared, at which Sicilians sacrificed. The best evidence for the worship of Daphnis on Sicily, however, comes from Nymphodorus, the $3^{\text {rd }}$ century B.C. Syracusan historian. The scholia to Theocritus (1.65-6b-c) paraphrase Nymphodorus' report that Daphnis' dogs died along with him, and that their names were recorded at his tomb. As Jennifer Larson has suggested, these details probably indicate that Daphnis was the object of hero worship on Sicily. ${ }^{34}$

These accounts are not, on the surface, easy to reconcile with the events of Idyll 1, although I hope that this chapter (and especially Chapter 2) will help square Theocritus' portrait

\footnotetext{
${ }^{34}$ Larson (2001) 80.
} 
of Daphnis with the non-Theocritean versions. The differences in detail, however, are telling: they point to a Daphnis tradition independent of Theocritus. It is thus highly unlikely that Theocritus was the first to recount the story of Daphnis. Not only are there pre-Theocritean or near contemporary mentions of Daphnis (Stesichorus, Timaeus, Nymphodorus), but the alternate accounts include some details that are left as implications or excluded altogether from the first Idyll. Thus, for instance, even if it may lurk in the background (as we will see in Chapter 2), Daphnis' status as a hero is not pressed in Idyll 1, in contrast to the report of Nymphodorus, and his dogs are not mentioned at all. Likewise, Theocritus hints at Daphnis' close relationship to the nymphs in his poem, but we must rely upon other sources to inform us of his erotic relationship with one of them. Even if that relationship is the cause of his suffering in Idyll 1, as indeed seems likely, given the evidence of Timaeus/Parthenius, Diodorus and Aelian, this background is left to the reader to decipher. The nature of Daphnis' suffering in Idyll 1 is itself confusing, since Theocritus differs from the anecdotal tradition concerning the end result of the cowherd's pain: the tradition makes blindness his punishment for betraying the nymph, whereas the Idyll depicts his death. These differences in detail, along with the fact that Theocritus seems to be working from a broader narrative than actually appears in the first $I d y l l$, suggest that Daphnis already had a lengthy pre-history on Sicily before Theocritus composed the song of Thyrsis.

The first Idyll does indeed presuppose an existing body of stories on a number of

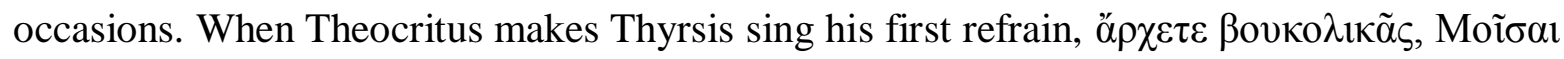
$\varphi\left(i \lambda \alpha 1, \ddot{\alpha} \rho \chi \varepsilon \tau^{\prime} \dot{\alpha} \operatorname{ol} \delta \tilde{\alpha} \varsigma\right.$, he symbolically initiates the new bucolic mode ${ }^{35}$ but even as he draws attention to the novelty of this new type of poetry, the poet treats the content of his composition as highly conventional, part of an ongoing, Sicilian oral tradition. The goatherd that asks Thyrsis to sing is already aware of the latter's reputation for reciting the Sufferings of Daphnis, and

\footnotetext{
${ }^{35}$ Cf. Hunter (1999) 61, 86-87.
} 
suggests that he has done so frequently: $\tau \grave{\alpha} \Delta \alpha \dot{\alpha} \varphi v 1 \delta o \varsigma \alpha \alpha \lambda \gamma \varepsilon \varepsilon^{\prime} \dot{\alpha} \varepsilon i ́ \delta \varepsilon \varsigma$ (19). The present tense ${ }^{36}$ of the verb "to sing" indicates that Thyrsis has sung the Sufferings of Daphnis on numerous occasions, as suggested by Hunter ad loc. and Gow's translation: “wont to sing." ${ }^{37}$ The "Sufferings of Daphnis," then, are not the spontaneous creation of Thyrsis at the moment of

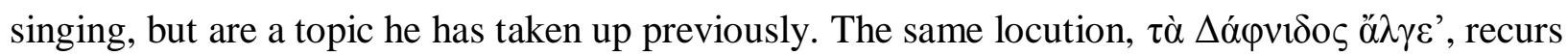
at Idyll 5.20, where, as Hunter notes, "the phrase is used as proverbial for the worst fate which can befall a herdsman." ${ }^{38}$ Once again, Theocritus depicts the story of Daphnis not as a novel creation but as something traditional and well-known to the characters of the Idylls.

Theocritus, moreover, portrays Thyrsis' repeated performance of the Daphnis ballad as part of an ongoing, Sicilian oral tradition. ${ }^{39}$ The poem begins with an exchange between the two herders about the quality of prizes that each would win in imagined competitions with Pan and the Muses. Even if facetious, the dialogue here alludes to an agonistic context, with discussion of

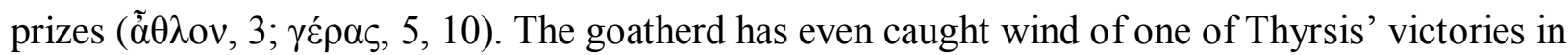
poetic competition with the ballad of Daphnis, in a match against a Libyan named Chromis (24):

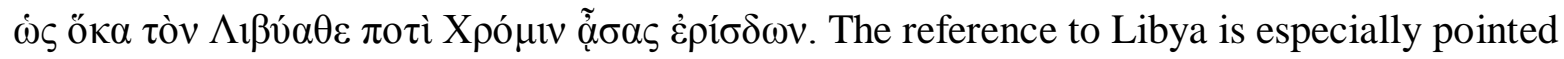
here when considered as a parallel to $I d$. 16.76-9, which depict Libyan Phoenicians as trembling in fear at Syracusan power. As a man from Aetna (65) singing the Sufferings of Daphnis against the Libyan, Thyrsis represented his hometown with a song drawn from its particular lore: Idyll 1 clearly lays claim to Daphnis as a Sicilian character.

Furthermore, Thyrsis' song about Daphnis is rife with mentions of geography. His ballad creates a tension between here and elsewhere, local and foreign; it enacts a dialogue of place.

\footnotetext{
${ }^{36}$ Hunter (1999) 74; Gow (1952) vol. 2 5. On the form, Doric - $\varepsilon \varsigma$ for - $\varepsilon 1 \varsigma$, see Hunter (1999) 71.

${ }^{37}$ See Smyth 1876, "Present of Customary Action."

${ }^{38}$ Hunter (1999) 74.

${ }^{39}$ For public performance in Idyll 1, see Chapter 2, pp. 95-96.
} 
Thyrsis begins by identifying himself as a man from Aetna, and proceeds to chastise the nymphs for being any place other than Sicily during Daphnis' woes, contrasting famous Thessalian locations with famous Sicilian sites (65-69):

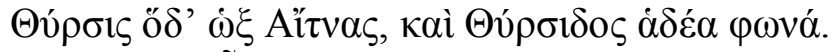

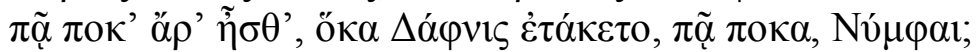

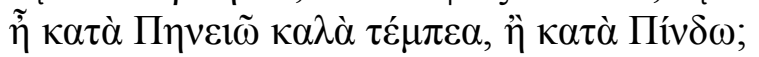

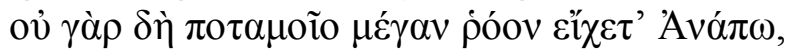

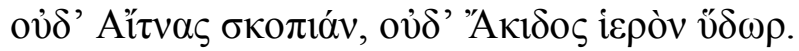

I am Thyrsis of Aetna, and the voice of Thyrsis is sweet. Where were you then, Nymphs, where were you, when Daphnis was wasting away? Were you by the lovely glades of Peneus, or those of Pindus? For you did not haunt the great flood of the Anapus River, nor the peak of Aetna, nor the sacred stream of the Acis.

The Anapus flows into the sea by Syracuse, while the Acis emerges from beneath Aetna. ${ }^{40}$ When Thyrsis mentions Aetna in 69, it is the second time in only five verses; in claiming Aetna not only as his home town, but also as the setting of the poem, Thyrsis draws a link between himself, his native land, and the events of the poem: this is a local singer, singing local lore and celebrating a local place.

From the start, moreover, Thyrsis addresses the nymphs, who are placed emphatically at line end, in a verse full of consonance, assonance and repetition (66). Beginning with a set of rhetorical questions to the nymphs is yet another way to press home the theme of locality. nymphs are local divinities par excellence, inhabiting particular features of the landscape like mountains and rivers (the very features listed by Thyrsis in his reproach of them), and they had the potential to form closer relationships with their human neighbors than was usual for Olympian deities. ${ }^{41}$ Daphnis himself was a favorite of the Nymphs (141); his mother is sometimes reported to have been a nymph (Diod. 4.84; Aelian $V H$ 10.18), and a nymph is said to

\footnotetext{
${ }^{40}$ Hunter (1999) 88.

${ }^{41}$ Larson (2001) 8-11.
} 
have been infatuated with him. ${ }^{42}$ Traditions about and worship of particular nymphs could contribute to the formation of a regional identity. ${ }^{43}$ In invoking the nymphs, together with local geographical landmarks, therefore, Thyrsis evokes a body of beliefs and traditions attached to his native region.

Later in his song, when Thyrsis impersonates the legendary herder from a first-person perspective, he refers several times to Sicily's landscape, but further develops the picture by introducing elements associated with the Near East to provide a contrasting counterpart. Toward the end of Daphnis' lament, the suffering cowherd bids farewell to Arethusa (117), linking himself to Theocritus' home town of Syracuse: the spring Arethusa is located at heart of that city, on the island of Ortygia. In the next line, the cowherd says farewell to the Thybris, another feature of Sicilian geography, probably also near Syracuse. ${ }^{44}$ Moreover, Daphnis offers a short, mocking catalogue of Aphrodite's previous lovers and antagonists (105-113): Anchises, Adonis, and Diomedes. Although the mention of Anchises and Diomedes certainly raises generic issues, contrasting Daphnis and the bucolic world with the realm of epic, the reference to these three figures also serves a geographical purpose. Aphrodite's affairs with Anchises and Adonis both take place in the Near East, as does Diomedes' battle with the goddess. The catalogue is, therefore, yet another way for Theocritus to emphasize Daphnis' Sicilian origins in contrast with figures from elsewhere: the local figure of Daphnis stands in opposition to the three characters familiar to readers from epic and Pan-Hellenic tradition. ${ }^{45}$ The comparison of Anchises, Adonis, and Diomedes with the Sicilian herder is especially noteworthy in light of the similarity of Daphnis to Adonis and Anchises, i.e. the herder-hero who acts as paredros to the eastern fertility

\footnotetext{
${ }^{42}$ Diodorus (4.84), Timaeus in Parthenius (Narr. Ama. 29), Aelian (VH 10.8).

${ }^{43}$ Larson (2001) 213-214; Sourvinou-Inwood (2005) 265-266; below, pages 58-59.

${ }^{44}$ Hunter ad loc.

${ }^{45}$ See Griffin (1992) 201. See also below, 33-34.
} 
goddess. ${ }^{46}$ It is at first difficult to understand why Daphnis links Diomedes with Anchises and Adonis. His relevance to the group becomes clear, however, if we remember that the Argive's confrontation with the goddess in Book 5 of the Iliad occurs in the aftermath of his wounding of Aeneas, Aphrodite's offspring by Anchises. Not only, then, does the mention of Diomedes raise the embarrassing issue of the wrist-wound Aphrodite suffers at his hands, but also the injury he causes to her love-child with Anchises (5.297-351). For our purposes, however, the most important point remains geographical: Theocritus' mocking catalogue draws an analogy between Daphnis' Sicilian travails and the far-off, Near Eastern adventures of Anchises, Adonis, and Diomedes, but simultaneously contrasts those foreign personages with his own local hero. Idyll 1 amply establishes that Daphnis is a figure of local cultural importance by making him the subject of an Aetnan bard and connecting him to the Sicilian landscape. That Thyrsis is a rustic shepherd suggests a connection not only between the ballad of Daphnis and local tradition, but popular tradition as well, which necessitates an investigation into the herder's origins and the cultural context that brought him into being. That inquiry will be the subject of the rest of this chapter, where I will examine Daphnis' origins in cult and popular song competition and his connection to the cultural identity of Sicilian colonists from the Doric Peloponnese. These findings will have consequences for Theocritus' entire bucolic program, which frequently values the local at the expense of the Pan-Hellenic or international and constitutes an effort to craft a coherent Sicilian and Doric cultural identity.

\section{THE ORIGINS OF DAPHNIS}

The evidence about Daphnis and the origins of bucolic poetry is full of apparent

\footnotetext{
${ }^{46}$ This topic will be taken up in greater detail below, pages 26-46. See Berg on Adonis and Anchises and the Near East, as well as Halperin 189-190, and Griffin (1992) who discusses Anchises and Adonis in terms of Near Eastern traditions as they appear in the Iliad. On 210-211 Griffin discusses Idyll 1.100-102.
} 
contradictions. On the one hand, we would expect Daphnis as bucolic's legendary founder to appear in anecdotes about the origins of this poetic mode. But while the scholiastic stories about bucolic's genesis do not mention Daphnis, they do locate bucolic's origins in popular song performances. Yet these anecdotes raise another problem in turn: those popular song performances are reported to take place in the context of the worship of Artemis, who appears, at least in the Idylls, to have little or no relationship to bucolic poetry. Another issue arises when we consider that one of the most plausible lines of thinking about the genesis of bucolic poetry situates Daphnis' origins in the Near East, comparing him to paredros figures like Dumuzi and Tammuz, male consorts to the great female goddesses Inanna and Ishtar. ${ }^{47}$ Such a theory, however, does nothing to explain Daphnis' special connection to Sicily. Thus, while Dumuzi and Tammuz offer striking parallels, the theory of Near Eastern origins does not explain Daphnis’ Sicilian context. How the Near Eastern paredros may be related to a popular figure from Sicily, whether the notion of Near Eastern origins can be reconciled with the connection to popular festivals of Artemis, and what Artemis has to do with bucolic in the first place is the conundrum that will occupy us here. Beginning with an overview of the Near Eastern and scholiastic approaches, I will propose a theory that reconciles these divergent approaches, and helps to clarify the Doric and Siclian cultural context that gave rise to Daphnis and the origins of bucolic poetry.

\section{The Near Eastern Model of Bucolic Origins}

The pairing of Daphnis and Aphrodite in Idyll 1 has long reminded scholars of the male paredros of the great Near Eastern fertility goddess in her many incarnations. William Berg and

\footnotetext{
${ }^{47}$ On paredroi see Burkert (1979) 105-106; Halperin (1983a) 187, 190; Carter (1987) 183 and passim; West (1997) 57. Such paredroi are also known as dying and rising gods, on which see the surveys by Smith (2001) 104-130 and Mettinger (2001).
} 
David Halperin ${ }^{48}$ offer two of the most useful accounts of Daphnis' Greek predecessors and the Near Eastern herder-divinities from which such figures descend. In particular, these two scholars locate Daphnis in a tradition ultimately related to the Sumerian shepherd-god Dumuzi and the fertility goddess Inanna, as well as the many subsequent and related pairs of deities (e.g. the fertility goddesses Ishtar and Aphrodite, along with their male paredroi Tammuz and Adonis). Halperin summarizes Berg's findings concisely:

Berg contends that Theocritus' Daphnis unites elements originally belonging to a variety of pastoral figures in early ritual and legend. Like Dumuzi and Tammuz, Daphnis sings his own lament; like Dumuzi, Tammuz, Adonis, and Attis, he is the subject of ritual mourning; like Dumuzi, Tammuz, Adonis, Attis, and Anchises, he is destroyed by a goddess who represents the generative principle in nature; and like Dumuzi, Tammuz, David, Anchises, Paris, and Orpheus, he is a great musician. Finally, like Dumuzi, Tammuz, David, Adonis, Attis, Anchises, Paris, Orpheus, and the historical Hesiod, Daphnis is a herdsman who encounters divinities in the isolation of a pastoral landscape. ${ }^{49}$

Halperin builds on Berg's theory and searches for similarities between Daphnis and figures of Near Eastern myth and cult to elucidate certain aspects of Daphnis' character and the narrative that surrounds him. ${ }^{50}$

Attempts to identify paredroi from different cultural contexts have been subject to scholarly suspicion. It was James Frazer who first unified figures like Dumuzi, Tammuz, Adonis, Baal, Attis and Osiris under a single title, the so-called "dying and rising god," whose lives and deaths supposedly reflected the annual fertility cycle, symbolized in the myths attached to these

\footnotetext{
${ }^{48}$ Berg (1974) 13, 17-20; Halperin (1983a) 183-200.

${ }^{49}$ Halperin (1983a) 188-189, summarizing Berg (1974) 17-20.

${ }^{50}$ In addition to discussing Daphnis' kinship to the paredros figure of Near Eastern myth and the aura of divinity it lends to Idyll 1, Halperin is especially interested in a set of characteristics that Thorkild Jacobsen attributes to Tammuz/Dumuzzi, namely, "intransitiveness," "ethical neutrality," "youthfulness," "belovedness," "defenselessness and suffering," and "attractiveness to women." See Halperin (1983a) 194 summarizing Thorkild Jacobsen, Toward the Image of Tammuz and other Essays on Mesopotamian History and Culture, 1970, ed. William L. Moran, Harvard Semitic Studies 21 (Cambridge) as well as Jacobsen, 1978, Treasures of Darkness: A History of Mesopotamian Religion (New Haven).
} 
deities and celebrated in seasonal cult. ${ }^{51}$ The concept of the dying and rising god has continued to exert considerable influence in the fields of Near Eastern and Classical studies, despite severe criticism in more recent years of Frazer's methodology and chief assertions. Scholars have objected especially to Frazer's tendency to find similarity between these gods without considering their native contexts and while ignoring the sometimes substantial differences between them. Scholars have doubted that mythology concerning these divinities has a basis in ritual concerning vegetation and have questioned whether they are all dying and rising gods in the first place. ${ }^{52}$ Frazer has also been faulted for paying too little attention to primary sources and depending too heavily on the distorted vision of Near Eastern material reported to us from ancient Classical texts. ${ }^{53}$

Despite these criticisms of Frazer and his category of dying and rising gods, the careful work of T. N. D. Mettinger has recently found evidence from myth and cult that a number of gods from the Near East were believed to die and return to life, including Dumuzi, Baal, Melqart and the Levantine Adonis. These deities were closely linked to yearly plant cycles, and probably historically connected in a number of instances. ${ }^{54}$ Thus, argues Mettinger, traditions about Dumuzi influenced those concerning both Ugaritic Baal and Adonis. ${ }^{55}$ We must be careful not to ignore the differences between these gods and simply view them as a single entity, without regard for their individual traits and cultural contexts. Yet even scholars who eschew the label of dying and rising gods have taken note of similarities and historical connections between them. ${ }^{56}$

\footnotetext{
${ }^{51}$ Smith (2001) 105-108. For a very thorough list of past scholarship on dying and rising gods, see Smith (2001) 253-254, notes 1-2.

${ }^{5}$ Smith (2001) 108-110 for a general overview, 110-120 for arguments pertaining to individual gods.

${ }^{53}$ Smith (2001) 109-110.

${ }_{55}^{54}$ Mettinger (2001) 217-20 and the chapters on individual gods.

${ }^{55}$ Mettinger (2001) 207-212.

${ }^{56}$ See, e.g. Burkert (1979) 105-111; Halperin (1983a) 186-187. Some critics of the category "dying and rising gods" have found a more favorable alternative in the term "Disappearing Gods," a broader but still meaningful way of finding similarities in these deities (Smith [2001] 121; Smith, J.Z. [1987] 521-527). One such scholar, Mark S.
} 
It is in this cautious vein that Halperin proceeds, noting the difficulties with Frazer's

method, but also finding a productive way to discuss the shared traits between Dumuzi,

Tammuz, Adonis and Daphnis. ${ }^{57}$ Despite, however, his interest in foreign religion and literature,

Halperin does not examine in detail the possible avenues of transmission by which Near Eastern, foreign cults might have been assimilated into Greek, especially Sicilian, local cult. Although Halperin is willing to speculate about an almost inexplicable stability in certain aspects of ritual and myth, he does not go further:

There is obviously no question of direct literary influence on the Greek bucolic poets of Mesopotamian religious texts: the intervals of time separating Theocritus from the Sumerian and even from the Akkadian hymnographers are too vast, even if the Phoenicians may have served as intermediaries at certain points. To be sure, one need not claim any familiarity on the part of Theocritus with pre-Hellenic sources: it is doubtless more attractive to posit a vague continuity of religious tradition or a substratal inheritance comprising both ritual and mythology $[\ldots] .{ }^{58}$

Although Halperin is surely right to be cautious in the face of such vast "intervals of time," that caution leaves us only with speculation and discourages a careful investigation of local myth and cult, which may indeed be relevant to bucolic poetry. Thus, while Halperin is quite willing to turn his attention to distant Near Eastern forebears of Daphnis, he is more hesitant to discuss the potential value of such connections for ancient Sicilian culture. Taking an outside-in approach, he does not investigate how Greek or Sicilian incarnations of the Tammuz/Dumuzi/Adonis complex may have developed in their own cultural milieu. Rather, Halperin's default stance gives precedence to the international at the expense of the local. Thus, for him, Daphnis is reduced to a mere imitation of Adonis: it is Theocritus who transforms Daphnis "into the

Smith, in a recent survey of so-called dying and rising gods, rejects a universal connection between these deities and vegetation rites, but does argue for a shared connection between these gods and royal funerary ritual (Smith [2001] 120). Even if he disavows a universal connection, moreover, between these gods and vegetative rituals, he nonetheless notes a shared metaphorical connection between this group of divinities and vegetation (Smith [2001] 121).

${ }^{57}$ See especially Halperin (1983a) 185-187.

${ }^{58}$ Halperin (1983a) 199. 
presiding genius of the Sicilian landscape" ${ }^{59}$ in imitation of Adonis. Yet our review of the sources and of Theocritus' own treatment of Daphnis suggests that the Sicilian cowherd was already part of a vibrant tradition before the composition of Idyll 1 .

\section{Forebears of Daphnis: Greek Literature, Sicily and the Near East}

Indeed, a survey of sources related to Daphnis demonstrates that Theocritus would have had access to stories like that of the Sicilian herder not only from myth and literature, but very possibly from exposure to contemporary cults on Sicily. What lies behind the seemingly mysterious sequence of events constituting the algea Daphnidos is a narrative in which a female deity or her proxy causes a young male to die or harm himself out of erotic jealousy. ${ }^{60}$ The Daphnis story is part of a larger group of narratives in which a female deity or the proxy of that deity seduces or attempts to seduce a mortal male or a dying god; whether the seduction succeeds or fails, the male is then destroyed by this erotic contact; in many instances, the destruction of the male results from his violation of an injunction placed upon him by the goddess. This pattern has roots stretching back to Sumer and exerts its influence even into Hellenistic Greek and Punic spheres. Many of the mythological and cultic figures at the center of these narratives of erotic jealousy are of the same type as Daphnis, namely, paredroi of a major female goddess. I will now survey a number of parallels to the story of Daphnis, drawing on examples from both Greek and Near Eastern sources. Most importantly, this survey will encompass a number of figures who were worshiped on Sicily. ${ }^{61}$ In beginning to investigate the

\footnotetext{
${ }^{59}$ Halperin (1983a) 200.

${ }^{60}$ See also below, 79-80.

${ }^{61}$ Daphnis' appearance of abstinence in Idyll 1, along with his closeness to Artemis and hostility toward Aphrodite, has caused some commentators to see him as a Sicilian Hippolytus, who will not be discussed in detail here (E.g. Gow [1952] 2.2, with n. 1; Lawall [1967] 19-22. Cf. Halperin [1983] 192-193. Larson [2001] 80 and Gutzwiller [1991] 96 and 99). Indeed, the two are very similar in their stories and in certain aspects of their characters. Hippolytus is a young, handsome hunter, close to Artemis, as is Daphnis. Both are openly hostile and disrespectful to Aphrodite, who causes their destruction. Yet there are differences as well: Daphnis is not the prude that
} 
worship of paredroi on Sicily, I hope to demonstrate that the possibility of Near Eastern cults influencing the development of Greek bucolic poetry on the island was a concrete reality. The reconstruction of a context in which a Near Eastern paredros came to be worshiped in a distinctly Doric Greek, Sicilian milieu with close connections to Greek bucolic poetry will be considered in more specific detail during discussion of Daphnis and Ortheia.

\section{Dumuzi}

The main narrative impetus of the algea Daphnidos finds its earliest parallel in the Sumerian Dumuzi-Inanna love songs. In a poem known as “The Women's Oath,” Inanna places an injunction upon her consort, insisting that he take an oath that he will take no other lover. ${ }^{62}$

13-16. "For as long as you live, as long as you live, you shall take an oath for me, brother of the countryside, for as long as you live you shall take an oath for me. You shall take an oath for me that you will not touch another. You shall take an oath for me that you will not ...... your head on anyone else."

17-20. "My one who wears the ..... niglam garment, my beloved, man of my heart! I shall impose an oath ...... on you, my brother of the beautiful eyes. My brother, I shall impose an oath on you, my brother of the beautiful eyes."

21-26. "You are to place your right hand on my genitals while your left hand rests on my head, bringing your mouth close to my mouth, and taking my lips in your mouth: thus you shall take an oath for me. This is the oath of women, my brother of the beautiful eyes." (t.4.08.02 ETCSL).

Several similarities of this passage with the story of Daphnis should be noted. First, the injunction that Inanna places upon Dumuzi is strikingly similar to that which the nymph places

Hippolytus is: unlike Hippolytus, Daphnis is willing to have sex with a woman. Not only does Daphnis sleep with the nymph who is in love with him, as the tradition reports, but he also breaks his oath to this nymph by sleeping with another woman. For Daphnis, his inability to refrain from sleeping with a woman causes his destruction, whereas for Hippolytus, it his desire to refrain from sexual contact with all women that destroys him. Thus, even if the overall narrative structures of the Hippolytus and Daphnis tales are parallel, the motivations of each character differ drastically. Formally, however, it is important to note that it does not really matter whether Daphnis sleeps with a woman or heroically resists a woman. While that difference of detail certainly matters to the character of Daphnis, it does not alter the main narrative of the story of a Daphnis or a Hippolytus, in which a young pastoral figure comes into contact with female sexuality and is destroyed for it as a result. Whether that sexuality is consummated is irrelevant - the contact with sexuality alone is sufficient to destroy these young men. Cf. Halperin (1983a) 192-193 and Burkert (1979) 111.

${ }^{62}$ On this text, see Sefati (1998) 128-131, who also provides the translation and commentary for this text in Hallo and Younger (2003) 540-541. For more extensive commentary, see Sefati (1990) 45-63. The translation provided here is the version labeled t.4.08.02 on ETCSL. 
upon Daphnis, namely, to swear that he will take no other lover. The repeated emphasis upon the "otherness" of Dumuzi's hypothetical lover is also to be noted. In lines 15-16 above, Dumuzi must swear that he "will not touch another" and that he "will not [perform an action with his] head on anyone else." The word used for "another" and "anyone else" in both lines is lú-kúr-ra, the dative of lu-kur, meaning "stranger" (ETCSL transcription), also translated as "alien" by Sefati ${ }^{63}$ It is striking in this light to recall that the name of Daphnis' lover mentioned by Theocritus in Idyll 7 is $\Xi \varepsilon v \varepsilon \dot{\alpha} \alpha$, which is constructed from the Greek word meaning "stranger" or

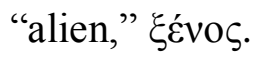

But the love between Inanna and Dumuzi is not always as happy as "The Women's Oath" may suggest. The power of Inanna's love to harm her beloved became a topos in Near Eastern literature. In the Epic of Gilgamesh, the hero cites Dumuzi’s fate as Inanna's lover as a reason not to submit himself to her affections (6.2.42-47):

Which of your lovers [lasted] forever?

Which of your masterful paramours went to heaven?

Come, let me [describe (?)] your lovers to you!...

For Dumuzi the lover of your youth

You decreed that he should keep weeping year after year. (trans. Dalley)

In the Sumerian version of the "Inanna's Descent," the goddess's jealousy appears to cause the death of her beloved consort. The goddess is allowed to leave the netherworld on the condition that she supply a substitute to die in her stead. As she searches for an adequate replacement, she comes upon Dumuzi. Unlike the other characters she meets in her search, Dumuzi is not in mourning garb, but is decked out instead in festive attire. As Jacobsen has pointed out, Dumuzi's inappropriate dress contrasts "so glaringly with the mourning garb he should have been wearing, desolate at the loss of Inanna" that it "understandably triggers Inanna's jealousy in a flash of hot

\footnotetext{
${ }^{63}$ Sefati in Hallo and Younger (2003) 541. See also Sefati’s commentary on the line (1990) 57.
} 
anger." ${ }^{64}$ In her anger, the goddess chooses Dumuzi as her replacement in the underworld. Her jealousy here may be linked to Dumuzi's adulterous behavior, ${ }^{65}$ and several scholars link the episode of jealousy in the "Inanna's Descent" with another poem, "The Guilty Slave Girl," which depicts Inanna's punishment of a girl with whom Dumuzi has had an affair. ${ }^{66}$

In the story of Inanna's jealous love, then, we find already the key components of Daphnis' story: a female divinity places an injunction upon a young, male mortal or dying god that he love no other woman. Her jealous love eventually ends up killing the young male, probably in both cases due to a fit of anger over the young man's adulterous behavior. The motif of Dumuzi's destruction at the hands of Inanna's jealous love had an enormous influence in later literature, including Greek sources. Among other parallels, the relationship between Inanna and Dumuzi appears to have shaped the depiction of Aphrodite and Anchises in the Homeric Hymn to Aphrodite. ${ }^{67}$

$\underline{\text { Anchises }}$

The parallel to Anchises is especially striking since Theocritus mentions the events of the Homeric Hymn in Idyll 1 itself, in a passage that also mentions Adonis (1.105-107, 109-110):

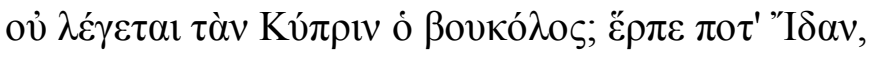

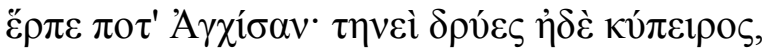

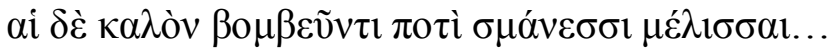

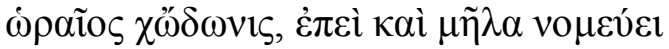

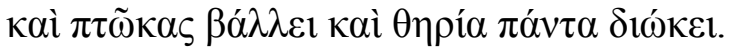

Isn't there a story about Cypris and the neatherd? Go to Ida, go to Anchises. Thither are there oaks and galingale, and the bees buzz prettily about their

\footnotetext{
${ }^{64}$ Jacobsen (1987) 225 n. 24.

${ }^{65}$ Hennie Marsman (2003) 169-170, esp. n. 13, has recently interpreted this passage as punishment for Dumuzi's adulterous behavior. She also discusses another poem in which it is generally assumed that Dumuzi is being adulterous.

${ }^{66}$ Jacobsen (1970) 206 on the adultery of Dumuzi. See also Hennie Marsman (2003) 170 n. 13. See Leick (1994) 213-216 for a different interpretation. On Dumuzi's unfaithfulness to Inanna in the context of the Daphnis narrative, see also Anagnostou-Laoutides and Konstan (2008) 501.

${ }^{67}$ Penglase (1994) 170-172. See also Faulkner (2008) 18-22.
} 
hives...And Adonis is also in his prime, since he pastures his flocks and shoots every hare and chases every beast.

After Aphrodite accosts Daphnis and throws his broken promise to the nymph in his teeth, Daphnis responds by mocking the goddess for her own previous love affairs. The first of Aphrodite's lovers that Daphnis mentions is Anchises.

As in the Dumuzi parallel, the basic outline of the Anchises narrative is strikingly similar to that of Daphnis. The mortal male Anchises comes into erotic contact with Aphrodite, who issues him a stern injunction, that he not inform anybody that the goddess is the mother of Anchises' son Aeneas. ${ }^{68}$ Anchises, however, breaks this injunction; as a result, the mortal herder ends up dead (in the version of Hyginus, Fab. 94), lame (Soph. fr. 373 Radt) or blinded (Theoc. ap. Serv. Verg. Aen. 1.617). Although Aphrodite's injunction to Anchises is not a prohibition of adultery, as in the cases of Dumuzi and Daphnis, the overall structure of the narrative remains consistent. $^{69}$

The parallel to Anchises is especially notable, given that it is one that Theocritus makes himself in Idyll 1. By mentioning Anchises, Daphnis draws Aphrodite's attention to the similarity between the two men: although the goddess may have caused Daphnis to break his oath to the nymph, but her own lover has also broken an injunction that she herself placed upon him. In addition, the mention of Anchises is also meaningful at a meta-narrative level: it indicates that Theocritus thinks of Anchises and Daphnis as similar characters. ${ }^{70}$

\footnotetext{
${ }^{68}$ On the injunction, see Larson (2001) 81 and the article of Graf's article in Brill's New Pauly, s.v. "Anchises."

${ }^{69}$ For parallels between Dumuzi and Anchises in the Hymn, see Penglase (1994) 170-172.

${ }^{70}$ Larson discusses the liaison between Aphrodite and Anchises in terms of the "Daphnis pattern" of a male who breaks a promise to a nymph. That scholar concludes that the most relevant comparanda for the Daphnis narrative are stories about men who consort with nymphs, but then come to harm after breaking an injunction placed upon them by the divinity, either not to sleep with anybody else, or to remain silent about the relationship (Larson [2001] 79-84. See 79-81 for this conclusion.). Thus, Anchises, a mountain herder like many of the other male protagonists of such stories, has sexual relations with Aphrodite (who, in Larson's view, takes the place of the nymph in this incarnation of the narrative pattern). Aphrodite makes Anchises swear an oath that he will never speak of their affair, but the Trojan breaks that vow of silence and is lamed or killed as punishment, according to different
} 
$\underline{\text { Adonis }}$

After Anchises, Daphnis mentions Adonis, yet another lover of Aphrodite who comes to harm following erotic contact with the goddess. Daphnis' recitation of this mini-catalogue of paredros figures is yet another indication that Theocritus is conscious of their similarity. Indeed, Theocritus was correct, from a historical as well as a narrative perspective. Recent arguments by Mettinger have reaffirmed a point of view that had come under criticism recently, namely, that Adonis is ultimately influenced by Dumuzi. ${ }^{71}$ But Theocritus' grouping of Adonis with both Daphnis and Anchises is also warranted from the point of view of narrative. Not only do all three come to harm after sexual contact with a female divinity, but, as with Daphnis and Anchises, there are indications that Adonis' destruction also follows closely upon his breaking of an injunction issued by Aphrodite.

This narrative is most plainly preserved in an admittedly late source, Ovid's

Metamorphoses (10.542-547):

te quoque, ut hos timeas, siquid prodesse monendo possit, Adoni, monet, 'fortis' que 'fugacibus esto' inquit; 'in audaces non est audacia tuta. parce meo, iuvenis, temerarius esse periclo, neve feras, quibus arma dedit natura, lacesse, stet mihi ne magno tua gloria.'

And she warns you too, Adonis, to fear these [fierce animals], if there were any point in warning him: 'Be brave with the timid ones,' she says; 'but it is not safe to be daring against the daring ones. Refrain, young man, from being bold when the risk is mine, and do not bother wild beasts, whom nature has armed, lest your

versions. While Anchises and Daphnis share a common narrative, also found in other stories concerning nymphs and mortal men, Larson plays down the influence of parallels originating in the Near East. In her view, these Near Eastern comparanda follow a slightly different narrative pattern than the stories involving nymphs and mortal men. But the stories about nymphs are ultimately part of a larger narrative group that also encompasses a pattern, attested as early as the Sumerian figure of Dumuzi, in which a male consort, either mortal or a dying and rising god, comes into erotic contact or proposed erotic contact with a female deity, and dies or is maimed as a result; of special note among these narratives are those in which harm comes to the male because he violates an injunction placed upon him by the female deity.

${ }^{71}$ Mettinger (2001) 209-214. 
glory be at great cost to me.'

Here Venus bids her mortal lover not go hunting ferocious game and she goes on to specify that he avoid wild boars in particular (549). Later on Venus repeats her warnings to her young lover (10.705-707):

hos tu, care mihi, cumque his genus omne ferarum, quod non terga fugae, sed pugnae pectora praebet, effuge, ne virtus tua sit damnosa duobus!

Run from such creatures, my dear boy, and every kind of beast that does not turn its back in flight, but holds its chest to the fight, lest your manliness be the downfall of us both.

But Adonis disobeys her and dies for it (709): sed stat monitis contraria virtus. A similar narrative is already implied in Bion's Lament for Adonis, where Aphrodite condemns her lover's

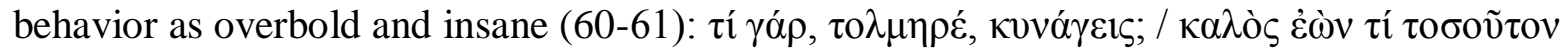

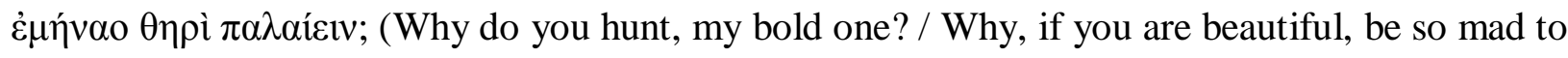
grapple with a wild beast?). Such language fits well with a narrative in which the goddess has begged Adonis not to go hunting.

The figures of Daphnis, Anchises and Adonis, therefore, are all at the center of narratives with similar plots, a plot that may well originate with Dumuzi, who is also the historic precursor of Daphnis, as discussed in Chapter 1. Theocritus calls attention to the similarity of these three figures in Idyll 1, when Daphnis mentions both Anchises and Adonis in his rebuke of Aphrodite.

Whereas Anchises and Adonis certainly would have been familiar to Theocritus from literature, it is important to realize that Adonis is one of a number of figures with narratives similar to that of Daphnis who also had a cultic presence on Sicily itself. The rest of this survey will address figures linked to Sicily, beginning with the evidence for Adonis' Sicilian cult. Like Daphnis, each of the figures about to be discussed has been linked by scholars to Dumuzi, both 
historically or from the point of view of narrative. Since each of these figures appears to have received cult in the relatively confined geographical and temporal region of early Hellenistic Sicily, it is likely that contemporaries of Theocritus would have noted the cultic and mythological echoes between them.

We will begin with the evidence for Sicilian worship of Adonis. An inscription from Nacone in Sicily (probably located between Segesta and Entella) ${ }^{72}$ tentatively dated to 254-241 B.C. preserves the name of the month Adonios (A $\delta \omega v$ viov). ${ }^{73}$ The name of the month is a strong indication that Adonis received cult at Nacone. ${ }^{74}$ In another example with implications for the cult of Adonis on Sicily, Ian Lee has argued that a coin minted from 464-460 or 455, hitherto wrongly attributed to Selinous, was more likely from Eryx. ${ }^{75}$ The image stamped on the coin is that of an anemone, leaf on the obverse and flower on the reverse, "which in mythology is sacred to Adonis, the lover of Aphrodite whose shrine at Eryx was one of the most celebrated in antiquity." 76 These examples from western Sicily demonstrate that Adonis, to whom Daphnis has been compared, was probably the object of cult at certain locations on the island. Eryx was recognized in antiquity as a cultic site of Aphrodite/Astarte which predated the Greek presence there (see, e.g. Diod. Sicul. 4.83.1-4). Cultic activity, including songs, at such multi-cultural sites might well have made its way into the Greek imagination. Although I argue in Chapter 1 that Daphnis emerges in a markedly Doric Greek context, a context that is important to the meaning of Idyll 1 and Theocritean bucolic as a whole, such a theory need not exclude the possibility of influence on that tradition from other cultural spheres.

The presence of Adonis-worship on Sicily indicates that figures similar to Daphnis make

\footnotetext{
72 See Salsano's article in Brill's New Pauly, s.v. "Nacone."

${ }^{73}$ SEG 30, 1119 lines 2, 9; Dubois (1989) 2.259.

${ }^{74}$ Dubois (1989) 259.

${ }^{75}$ Lee (1999) 1-31.

${ }^{76}$ Lee (1999) 2.
} 
up part of the island's mythical and ritual culture. The parallels between Daphnis and Adonis come to light especially by comparing the narratives that developed about each hero. Like Daphnis, whose name supposedly suggests the abundance of laurel at his place of birth, Adonis' birth-story is connected with vegetation. He is said to have burst from the bark of his mother after she had turned into a myrrh tree (Apollodorus 3.14.4; Ovid Met. 10.488ff). At his death, moreover, the blood of Adonis becomes the anemone flower (Ovid Met. 10.735-9). Both Adonis and Daphnis are renowned for beauty (Apollodorus 3.14.4; Ovid Met. 10.547-8). Both therefore were the object of the jealous advances of two females at once (Apollodorus 3.14.4). Both were shepherds (Theoc. 3.46). Both were hunters, and the story of Adonis' death during a boar-hunt is well known (Apollodorus 3.14.4; Ovid Met. 10.708-39). Adonis was famously the subject of ritual lamentations (Sappho 140; Aristophanes Lysistrata 708-39 with scholia; Theocritus 15.100-144; Lucian, de Syria Dea 6-7), and in Idyll 1 Daphnis sings a lament for himself. Adonis and Aphrodite were lovers (e.g. Theocritus 15.128-31), and Daphnis also takes a divine lover, a nymph.

Segal concluded that the Theocritus' treatment of the Adonis myth in Idylls 3 and 15 clearly indicate that Theocritus had come into contact with Adonis worship, though he contends that this must have happened at Alexandria. ${ }^{77}$ But the numismatic and inscriptional evidence discussed above suggests that Theocritus could have encountered the Adonis cult on Sicily as well. Adonis had long been a part of Greek literature by Theocritus' day. He is mentioned by Hesiod (139 MW) and Sappho (140 LP); he first comes to light in Athenian literature in Aristophanes' Lysistrata (708-39). But the possibility of Adonis worship on Sicily suggests an alternate source of Theocritus' familiarity with the Adonis worship: not literary, but cultic, and, moreover, not Alexandrian but local Sicilian cult. Given the similarity of the traditions

\footnotetext{
${ }^{77}$ Segal (1969) 86.
} 
surrounding Daphnis and Adonis, it is not implausible that local, Sicilian incarnations of the Adonis myth might have influenced the development of the Daphnis myth in Theocritus or his predecessors. Unlike Halperin, I do not suggest that the Adonis myth was the primary source of the Daphnis tradition, for reasons that will be made clear later in this chapter ${ }^{78}$ - but the two traditions may well have been mutually influential.

\section{$\underline{\text { Attis }}$}

Attis is another male consort who received cult on Sicily. ${ }^{79}$ The cult of Cybele appears in Syracuse as early as the $4^{\text {th }}$ century B.C. ${ }^{80}$ The most important center of Cybele worship on Sicily, however, was not at Syracuse, but at the great stone complex at Acrae, thirty-five kilometers to the west, a town originally founded by Syracuse and always close to its metropolis. ${ }^{81}$ The stone sanctuary at Acrae, dated to the $3^{\text {rd }}$ century B.C., ${ }^{82}$ illustrates the importance of Attis in Cybele's cult. It has been argued that the second, eighth and twelfth reliefs in Acrae contain statues of Attis, ${ }^{83}$ and such representations suggest that Attis was an object of veneration at the site. $^{84}$

Although not originally a dying and rising god, he is eventually portrayed as such, and the traditions surrounding Attis intersect at a number of points with those of other dying and rising gods. Burkert speculates that details from the narratives of Attis may link him to figures of deep Near Eastern antiquity, including Dumuzi, and Jan Bremmer has recently supported this conclusion. ${ }^{85}$ Details from the story of Attis are found to contaminate the story of the dying and

\footnotetext{
${ }^{78}$ See below, 49-65.

${ }^{79}$ For a recent review of material related to Attis, see Bremmer (2008) 267-302.

${ }^{80}$ Sfameni Gasparro (1973) 121.

${ }^{81}$ Sfameni Gasparro (1973) 126; Guzzetta's article in Brill's New Pauly s.v. “Acrae”; Bell (2011) 198.

${ }^{82}$ Sfameni Gasparro (1973) 141-142.

${ }^{83}$ Sfameni Gasparro (1973) 147, 269-70, 276.

${ }^{84}$ Sfameni Gasparro (1973) 144.

${ }^{85}$ Burkert (1979) 110-111; Bremmer (2008) 279.
} 
rising god Eshmun, as recounted in the $5^{\text {th }}$ century AD author Damascius (Vita Isidori 302). ${ }^{86}$

This overlap indicates that, at least by that late date, Attis was considered a dying and rising god.

More broadly, the overlap indicates a compatibility between the narratives of Attis and other

dying and rising gods, that regardless of the historical origins of the various traditions,

consumers of their respective narratives found enough common characteristics to link the

figures.$^{87}$ Due to a number of shared characteristics Attis and Adonis could have been confused

by Greek worshipers of these two Near Eastern imports; Greek authors may also have played a

role in blurring the lines between the two figures. Certainly the shared characteristics between

Attis and Daphnis have been sufficient to invite comparison in the past. ${ }^{88}$

Like Adonis and Daphnis, Attis plays the role of a paredros, in his case of Cybele. Like Adonis and Daphnis, the story of his birth is closely associated with vegetation: in one account, Attis is born from an almond tree (Pausanias 7.17.11). The death of Attis, like that of Adonis, is also associated with vegetation: he dies beneath a pine tree, and his blood turns into violets (Timotheus in Arnobius 5.7). Attis is a hunter, and one branch of his tradition merges with that of Adonis: by some accounts Attis dies after being gored by a boar (Hermesianax in Paus.

7.17.10; Herodotus 1.43). Like Adonis and Daphnis, Attis is a pastoral character: from his earliest appearance in Greek art ( $4^{\text {th }} \mathrm{c}$. Athens), he is dressed like a shepherd. ${ }^{89}$ Like Daphnis, Attis was a musician, and, in particular, seems to have used his musical skills to please the goddess, playing instruments employed in the worship of Cybele. ${ }^{90}$ Daphnis, too, is said to have employed his musical skill for the particular enjoyment of a goddess (Diod. 4.84). Like both

\footnotetext{
${ }^{86}$ Mettinger (2001) 157-159. See also Lipinski (1995) 160, 165.

${ }^{87}$ For the resemblance of the Attis myth to those of other figures, including dying and rising gods, see Burkert (1979) 111.

${ }^{88}$ E.g. Halperin (1983a) 188-189; Berg (1974) 17-20.

${ }^{89}$ Roller (1999) 180.

${ }^{90}$ Roller (1999)181-182.
} 
Adonis and Daphnis, Attis is the object of jealousy for female divinities, a point we will take up in more detail in a moment. Moreover, after initially becoming jealously enraged with Attis, and even causing his death, the female divinities end up lamenting him (Timotheus in Arnobius 5.7; Paus. 7.17.12), and their lamentation is echoed by traditions of ritual mourning (Diod. 3.59.7). Adonis, of course, was also the subject of ritual laments, and Daphnis sings his own lament in Idyll 1, while the story of his suffering takes on a proverbial status (Theoc. 1.19, 5.20).

The story of Attis as reported by Timotheus (via Arnobius 5.5-7) and Pausanias (7.17.1012) is remarkably similar to the tale of Daphnis' destruction by a nymph. It will be important to note, however, that the narratives about Cybele sometimes split her persona into multiple figures. In particular, these stories frequently feature the hermaphrodite Agdistis. However, "A[gdistis] was an epithet of Cybele (Strabo 10,3,12) and is identified with her [...]." ${ }^{\text {91 }}$ So Cybele and Agdistis should be considered separate aspects of a single personage.

Timotheus (via Arnobius 5.5-7) and Pausanias report roughly the same tradition. The demon Agdistis, having been born with the genitalia of both sexes, is castrated. From the resulting blood, a tree springs up. That tree impregnates the daughter of a local river, and Attis is born. Thus, for all practical purposes, Agdistis is the mother of Attis, if the term 'mother' may be used of a castrated hermaphrodite. Attis is then exposed, and raised either by a goat (Pausanias) or by a shepherd but with goat's milk (Timotheus/Arnobius). Here is our first correspondence with the tradition of Daphnis: the Sicilian shepherd was said to have been exposed by his divine mother (Aelian). Attis is beautiful, and Agdistis falls in love with him and is a rival with Cybele for his affections. ${ }^{92}$ Though it is not highlighted in our sources, the passion of Agdistis for Attis is tantamount to incest, since Attis is spawned by a tree descended from Agdistis.

\footnotetext{
${ }_{92}^{91}$ Baudy's article in Brill's New Pauly s.v. “Agdistis.” See also Roller (1999) 180, 245.

${ }^{92}$ Roller (1999) 245.
} 
Timotheus/Arnobius reports that Agdistis demonstrated her love for Attis by taking the boy hunting, and giving him the animals she kills. The boy claims to have captured the game himself, until, under the compulsion of wine, he admits that the slain animals were gifts from Agdistis (5.6). Thus, Attis, like Daphnis, breaks a confidence under the influence of wine, though the confidence is not the same in each case. At this point, both Pausanias and Timotheus/Arnobius report that Attis goes off to marry the daughter of the king of Pessinus, a mortal princess. Agdistis, and, in Timotheus/Arnobius, Cybele as well, are enraged with jealousy, for they love Attis. They appear at his wedding and inflict damage upon the city of Pessinus, at which point Attis castrates himself and dies.

Thus, a narrative dynamic is at work here very similar to that in the Daphnis story. The paredros figure, beloved of an immortal (nymph/Agdistis/Cybele) has intercourse with or marries a mortal princess. As a result of the immortal female's jealous rage, the paredros suffers harm, blindness in one case, castration in the other (Pausanias and Timotheus/Arnobius make it clear that the castration is the fault of the jealous divine lover). Agdistis repents of what she has done, and begs Zeus to make Attis immortal or bring him back to life. This is refused, but it is granted that the body of Attis never decay. A similar pattern of jealous rage followed by regret is in evidence in Idyll 1, where Aphrodite at first mocks Daphnis, but, after he is destroyed, tries to revive him. ${ }^{93}$

The story of Attis as it appears in Diodorus (3.58-9) also shares some of these characteristics, but the parallels are more distorted. There, Cybele is herself a princess, exposed at birth and raised by wild animals in the mountains. She is a herder and a musician. Cybele falls in love with Attis, and becomes pregnant. She is then recognized by her parents, who turn out to be royalty. Cybele and Attis move into her father's palace, but when her father finds out that she

\footnotetext{
${ }^{93}$ Cf. Halperin (1983a) 191, who notes the same motif in Ugaritic tradition.
} 
is not a virgin, he kills Attis. Cybele goes mad with grief and wanders the countryside. Plague ensues, and the natives learn that they must treat her as a god and propitiate Attis with rites of mourning: they make an image of his body and sing dirges.

Like the versions reported by Pausanias and Timotheus/Arnobius, human royalty plays a large role in this story. But, whereas Attis was the center of a love triangle in the other versions, an object of desire for two females, one divine, one mortal, the roles seem to have collapsed here. Since Cybele eventually becomes a goddess in Diodorus' euhemeristic version, she can play the role of both female lovers, mortal and immortal. Thus, instead of Attis leaving his immortal lover to join a mortal princess at a palace, he simply accompanies Cybele to the palace when her royal lineage comes to light. So, despite appearances, Diodorus' version of the Attis story does seem to be related those of Pausanias and Timotheus/Arnobius. ${ }^{94}$

The three paredroi, Adonis, Attis, and Daphnis, are alike in some of their most defining characteristics. All three are beautiful hunters and herders, all subject to the jealous attention of female divinities. All are connected with vegetation, and, in particular, the birth of each figure is associated with a tree: the myrrh, almond, and laurel. All three are subject to ritualized lamentation after dying young, Adonis by goring, Attis sometimes by goring, sometimes by selfcastration, Daphnis by wasting away, as Idyll 1 describes. Daphnis and Attis are alike, as well, in being musicians. Moreover, both Adonis and Attis received cult on Sicily. The evidence of worship of Adonis and Attis on Sicily suggests that local cult, sacred art, and myth should be included among the possible influences on the Daphnis tradition, and, thus, on Idyll 1 of

\footnotetext{
${ }^{94}$ Diodorus' version is also strikingly similar to the formulation of the Daphnis myth that Longus will later relate. In that story, as here, the role of Daphnis is mirrored in his female beloved, Chloe. Both are exposed at birth, both are suckled as infants by herd animals, both at first live a pastoral existence, but come to be recognized for the royalty that they are. The same is true for Diodorus' version of the Attis tale, only the role that Attis plays in the narrative is suppressed in order to focus on that of Cybele. Cybele is, after all, the main focus of Diodorus' investigation when he relates this narrative (see the final line of 3.59). The similarity between the story of Attis and Cybele as related in Diodorus and the Daphnis and Chloe of Longus should reinforce our sense that the traditions of Attis and Daphnis are connected, and is all the more reason to suspect that their narratives might have comingled on Sicily.
} 
Theocritus.

Attis and Adonis are figures who, like Daphnis, ${ }^{95}$ ultimately made their way to Sicily from foreign origins; even if Greek authors were aware of their alien provenances, they were assimilated to greater and lesser degrees into Greek myth and cult. But such paredros figures are not restricted to Greek Sicily. The local Punic settlements also attest to similar figures, who were never fully assimilated into Greek lore.

\section{$\underline{\text { Baal Hamon }}$}

The first of these figures is Baal Hamon, a Punic god whose female companion was Tannit, a hypostasis of Astarte, with qualities akin to Inanna and Ishtar. ${ }^{96}$ The evidence for cults to Baal and Tannit is widespread in Punic Sicily. ${ }^{97}$ Lipinski compares Tannit's relationship with her consort Baal to that of a Venus lugens, arguing that she was responsible for the periodic resuscitation of the male dying god, a process symbolic of vegetation and fertility. ${ }^{98}$ Although little in the way of contemporary narrative has been preserved relating to Baal Hammon and Tannit, the portrait of their relationship as envisioned by Lipinski fits well with the narratives of other dying gods that we have examined, such as Dumuzi, Adonis and Daphnis. There is evidence of inter-cultural interaction with regard to Tannit on Sicily: Tannit becomes assimilated to a follower of Arethusa on Sicily, whose image may have been the model for images of Tannit on Punic coins. ${ }^{99}$ Tannit had been assimilated to Artemis herself as early as $400 \mathrm{BC}$, as evidenced by a Punic-Greek bi-lingual inscription from Athens. ${ }^{100}$

\footnotetext{
${ }^{95}$ See below, 49-65.

${ }^{96}$ DCPP s.v. Tanit, 438; Lipinski (1995) 203-205. On Astarte, see DCPP s.v. Astarté, 46-48, Lipinski (1995) 128154.

${ }^{97}$ Lipinski (1995) 199-206, 260, 423, 450; see also Brill's New Pauly, s.v. "Sicily," under the heading "Religion," by Kunz.

${ }^{98}$ Lipinski (1995) 199-206.

${ }^{99}$ Lipinski (1995) 205.

${ }^{100}$ CIS I.116 = KAI 53 = TSSI III.40; Teixidor (1980) 457; Lipinski (1995) 205.
} 


\section{$\underline{\text { Melqart }}$}

Originating around $800 \mathrm{BC},{ }^{101}$ the Phoenician dying and rising god Melqart was known to Greek authors as Tyrian Heracles; the association between these two deities is attested as early as the $5^{\text {th }}$ century. ${ }^{102}$ Like the other male dying and rising gods discussed here, Melqart was linked in cult to a goddess, Astarte. ${ }^{103}$ This pair originally served as the protecting divinities of Tyre, ${ }^{104}$ but their cult is attested broadly throughout the Mediterranean. ${ }^{105}$ On Sicily, Melqart was probably present at the famous cult of Astarte at Eryx, ${ }^{106}$ but cult sites were more widespread across the western portion of the island. Malkin has recently demonstrated that Doric Greek colonists to Sicly were able to superimpose their own myths about Heracles onto the landscape of western Sicily, on account of certain qualities the Greek hero shared with Melqart, whose Phoenician cult sites were already present. ${ }^{107}$ In addition to being another example of a male object of cult with connections to fertility, with an important female consort, whose sites of worship were widespread on Sicily there may be historical ties between the cult of Melqart and that of Dumuzi. ${ }^{108}$

\section{Connection to Local Cult}

Not only do each of the figures discussed here as parallels to Daphnis (Dumuzi, Anchises, Adonis, Attis, Baal Hammon and Melqart) have narrative and historical links to the cult of Dumuzi, but each of them (aside from Dumuzi and Adonis) was celebrated at cult sites in Sicily. In this light, one might expect that Daphnis, similar to these figures in other respects,

\footnotetext{
${ }^{101}$ DCPP s.v. Melqart; Lipinski (1995) 229.

${ }^{102}$ Herodotus 2.44 with Lipinski (1995) 234.

${ }^{103}$ Mettinger (2001) 97; Lipinski (1995) 232.

104 Malkin (2011) 124; Lipinski (1995) 226.

${ }^{105}$ DCPP s.v. Melqart; Lipinski (1995) 226-238.

${ }^{106}$ Malkin (2011) 123, 140. On Astarte at Eryx, see Lipinski (1995) 144-147.

${ }^{107}$ Malkin (2011) 119-141, esp. 139-141.

${ }^{108}$ Mettinger (2001) 211, 214.
} 
would also have been an object of cultic veneration, so it is not surprising when we then find indications of a Daphnis cult on Sicily. Virgil, in his fifth Eclogue, depicts Daphnis as a divinity (5.20ff). Servius, in commenting on the divinity of Daphnis in Eclogue 5 explains (ad 5.20) that Mercury (Hermes) took Daphnis up among the gods, and at the place of his apotheosis a fountain appeared, at which Sicilians sacrificed (as discussed on page 19). The best evidence for the worship of Daphnis on Sicily, however, comes from Nymphodorus, the $3^{\text {rd }}$ century B.C. Syracusan historian. The scholia to Theocritus (1.65-6b-c) paraphrase Nymphodorus' report that Daphnis' dogs also died with him, and that their names are recorded at his tomb. As Jennifer Larson has suggested, ${ }^{109}$ these details probably indicate that Daphnis was the object of hero worship on Sicily.

Since the tradition of Daphnis is so similar to the traditions surrounding Adonis and Attis, and since those heroes seem to have been the object of similar veneration, it seems likely that the cult of Daphnis was celebrated in a similar manner. But the existence of a Daphnis cult also illustrates his status as an independent mythic and cultic figure. Daphnis is undoubtedly similar to Adonis and Attis, and the three traditions may have influenced each other. Despite this similarity, however, most ancient commentators insist upon Daphnis' specifically Sicilian origins, and he does not seem to have been worshiped elsewhere. What we are left with, then, is a figure with his own mythic and cultic traditions, who, despite his similarity to figures of widespread veneration, is associated especially with Sicily. It is unnecessary to assume with Halperin that Theocritus in Idyll 1 is simply adapting Daphnis to resemble the more famous Adonis, or, for that matter, Attis, or any other dying god, even though their mythic and cultic traditions may have influenced that of Daphnis at some point. Rather, Daphnis' own, native Sicilian tradition provides a more likely source for the Daphnis of Idyll 1, who insists so heartily on his ties to the

${ }^{109}$ Larson (2001) 80. 
island in that poem.

Theocritus' choice of Daphnis as the central figure of his new bucolic mode is especially significant precisely on account of the herder's resemblance to similar figures who were also worshiped on Sicily. Given their similarities, Theocritus might have made Adonis or Attis the subject of Idyll 1. But such a choice would have drastically altered the nature of that programmatic $I d y l l$, as well as the nature of Theocritean bucolic as a whole. Theocritean bucolic is a product of a Doric Greek, especially Sicilian milieu. This perspective is a unifying feature of the bucolic Idylls, which is seen in the choice of setting (Sicily and Doric Magna Graecia) and hero (Daphnis, Polyphemus, various local herdsman), and is echoed as well in their language, which evokes real epichoric Doric dialects. Daphnis is the mythological keystone of this unifying Doric perspective. Without a Sicilian cultic hero as the legendary founder of the new literary mode, the whole edifice would tumble down. Adonis or Attis, much less Baal or Melqart, would simply not be appropriate. We will revisit this subject later on in this chapter. ${ }^{110}$

\section{The Scholiastic Model of Bucolic Origins}

Recent scholars who have looked for the origins of bucolic poetry, whether in the Near East or otherwise, have tended to dismiss or neglect an important alternative theory with very ancient roots, namely, the scholiastic tradition which locates the genesis of bucolic poetry in popular song employed in the worship Artemis in Laconia and Sicily. ${ }^{11}$ The tradition handed down by the scholia provides evidence that bucolic poetry is linked to popular Sicilian song and cult, which would help to contextualize the popularizing tendencies of the pastoral Idylls.

The notion that Theocritus' polished poetry might be linked to popular song has been

\footnotetext{
${ }^{110}$ See below, 65-67.

111 See Gutzwiller (1991) 4-5 for a concise overview of earlier approaches. Efforts to examine Near Eastern theories in light of the scholia are not unheard of. See Baudy (1993) 282-318.
} 
quickly dismissed by some modern scholars. ${ }^{112}$ Many critics, however, are willing to admit that the form and content of Theocritus' bucolic Idylls owe something to popular song, but, understandably, hesitate to go beyond fairly superficial speculation. ${ }^{113}$ Even scholars who admit the likelihood that Theocritus' bucolic poetry is in some way connected to Sicilian popular tradition are not as receptive to the suggestion that such popular songs could have been connected to the cult of Artemis. Richard Hunter, for example, says of the scholiastic tradition:

The scholia to T. are preceded by late antique or Byzantine versions of an essay

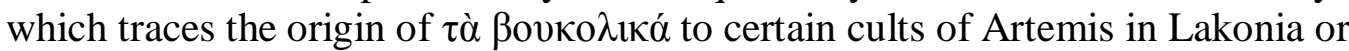
Sicily. T.'s surviving poems clearly have nothing to do with such rituals, and this scholiastic account, which perhaps goes back at least to Theon (Augustan period), seems to have been modeled upon Peripatetic accounts of the origins of Attic drama. Such a 'ritual' construction is in fact true to an important element in the literary history which $\mathrm{T}$. constructs for his own poems, but it tells us nothing about their designation or genesis. ${ }^{114}$

The tradition connecting bucolic to the cult of Artemis is far more plausible than Hunter suggests, though it requires further discussion and argumentation. Moreover, seen from the right vantage, the tradition linking bucolic to the rites of Artemis helps explain bucolic's selfdesignation as "popular song" and the prominence of Daphnis.

The scholia report three traditions about the discovery (heuresis) of ta boukolika, each of which concerns a festival of Artemis. The first anecdote takes place in Lacedaemonia, the second two in Sicily, specifically Tyndaris and Syracuse. The first tradition holds that, during the Persian invasion, Artemis Caryatis in Lacedaemonia did not receive her customary tribute of maiden songs, since the girls had all been hidden away in fear of the invading army. ${ }^{115}$ In order

\footnotetext{
${ }^{112}$ See, e.g. Halperin 1983 (a) 82-83.

113 See, e.g., Hunter (1999) 8-9 and Dover (1971) lix-lxiii. Examples of scholarship investigating ties to popular tradition include Cipolla (1979); Horowski (1973); Petropoulos (1959); Merkelbach (1956); Caberghs (1944); Di Mino (1931). In their articles for Brill's New Pauly on "Bucolics" and "Theocritus" respectively, Fantuzzi and Hunter both suggest the influence of local Sicilian traditions on the bucolic Idylls, but leave that influence rather vague.

${ }^{114}$ Hunter (1999) 5-6.

115 Scholia in Theocritum 2.5-12 Ba (Wendel).
} 
that Artemis might receive her due, the agroikoi entered the temple and sang their own songs

(idiais) to her. The second tradition ${ }^{116}$ contends that it was in Sicilian Tyndaris that ta boukolika

first arose. Because of its importance to the present argument, I give it here in full:

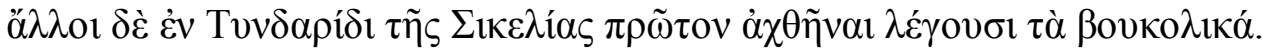

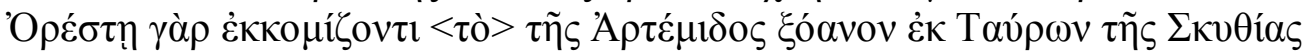

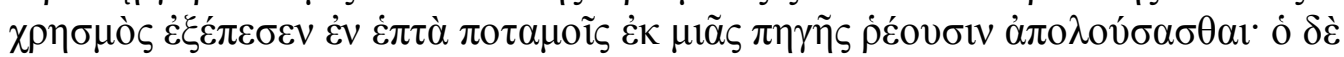

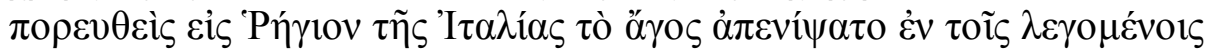

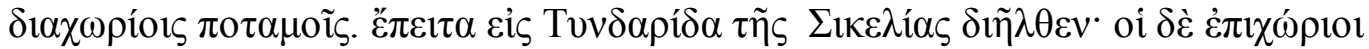

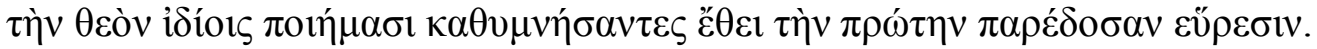

Others say that bucolic poetry first arose in Tyndaris in Sicily. For while Orestes was rescuing the cult-statue of Artemis from the Taurians in Scythia, he received an oracle to purify himself in seven rivers flowing from a single source. Having made the voyage to Rhegium in Italy, he cleansed his guilt in what are called the "Divided Rivers." Then he went across to Tyndaris in Sicily, and there the local inhabitants hymned the goddess with their own ${ }^{117}$ songs and passed down the first invention of the custom.

In contrast to the Lacadaemonian setting of the first account, the second anecdote claims that bucolic first arose when Orestes departed from the land of the Taurians and traveled to Tyndaris, where the inhabitants of that area (epichorioi) hymned Artemis with their own (idiois) poems. The third story is the most elaborate. ${ }^{118}$ Following an outbreak of stasis in Syracuse, it seemed to the people that Artemis had brought the conflict to an end. The agroikoi therefore brought the goddess gifts and had a singing contest in her honor. The singers would hang loaves of bread upon themselves in the shape of wild animals, with a sack full of all manner of seeds and a wineskin full of wine. They poured out libations to all they met, wearing a wreath and deer antlers and holding a shepherd-staff (lagōbolon, literally, a stick one throws at hares) in their

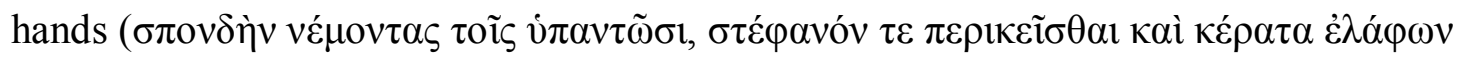

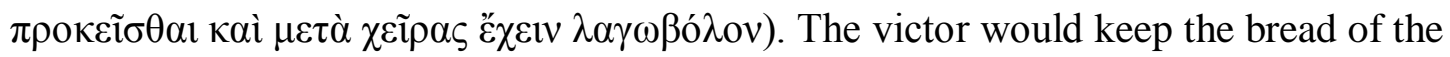

\footnotetext{
116 Scholia in Theocritum 2.13-20 Ba (Wendel).

${ }^{117}$ For this meaning of idíots, LSJ I.2, I.6.

118 Scholia in Theocritum 2.21-3.15 Ba-b (Wendel).
} 
vanquished, and would remain in Syracuse while the others went out of the city and begged for food, singing joyful things and a song of good omen. The ancient commentator who transmits these three stories believes that the third is "the true account," although this chapter will focus on the second anecdote.

While the scholia must certainly be approached with caution, their insistence on the importance of Artemis to bucolic must be accounted for. It is unlikely that such a detail would be invented; after all, the bucolic Idylls hardly even mention Artemis, so the ancient theorists were not simply mining the text of Theocritus' for a plausible origin story. Her presence in the scholiastic accounts, therefore, must be explained in another manner.

\section{The Missing Link: Daphnis and Artemis Ortheia}

While Berg and Halperin have made an important step forward by noting parallels to Daphnis from a Near Eastern religious context, there is a related cultic parallel closer to Sicily, which has not yet been fully exploited: the cult of Artemis Ortheia in Sparta. Not only is the local Spartan cult devoted to Artemis, but it has very likely been influenced by Near Eastern religious practice, as Jane Burr Carter has suggested. ${ }^{119}$ Artemis Ortheia, therefore, has the potential to bring together the differing strands of scholarship, namely, the theories that locate the origins of bucolic in Near Eastern cult and those that locate the origins in popular songs devoted to Artemis. While Greek bucolic certainly has relatives in the Near East, the most important bridge to that Near Eastern influence is to be found in the Doric Greek milieu of Archaic Sparta, a community which would have been of lasting cultural importance to the Doric colonies of Sicily such as Theocritus' own home town of Syracuse.

The Sanctuary of Ortheia at Sparta contains the remains of more than 600 votive

${ }^{119}$ Carter (1987) 355-383. On Sparta's connection to the Near East, see pages 54-56. 
terracotta masks ${ }^{120}$ dating from the late $7^{\text {th }}$ century B.C. and on, with the period of greatest production being the first half of the $6^{\text {th }}$ century B.C. ${ }^{121}$ While other archaeological evidence suggests a link between Ortheia and the Near East, these masks are the best example and so will be our focus here. ${ }^{122}$ Carter groups them into four categories: "furrowed grotesques, heroes, satyrs, and Gorgons." She describes the grotesques as follows: "grotesque faces, cheeks furrowed by deep S-shaped grooves and teeth bared."123 The "hero" masks are male faces, sometimes bearded, sometimes not. The un-bearded hero-masks, it should be noted, are youthful in appearance; as a result, accounts prior to Carter have labeled them "youths," while the bearded masks were classified as "warriors." Carter sees little to distinguish between the two sets, and groups them together as "heroes." ${ }^{124}$ She further specifies that "the mask represents an idealized male, presumably someone of super-mortal status, a hero or a deity."125

The purpose of these masks remains mysterious. Their construction suggests that they were meant to be worn, ${ }^{126}$ though the exact nature of the performances in which they were involved remains unclear. The rites of Ortheia, whose cult arrived at Sparta in the archaic age, ${ }^{127}$ appear to have developed in stages, although we can do little more than speculate about their nature. ${ }^{128}$ In the Classical period, Xenophon and Plato report a contest in which young boys

\footnotetext{
${ }^{120}$ Carter (1987) 355.

${ }^{121}$ Carter (1987) 358-359.

${ }^{122}$ For other archaeological evidence, see below, page 53-54.

${ }^{123}$ Carter (1987) 355.

${ }^{124}$ Carter (1987) 357-358.

125 Carter (1987) 366.

${ }^{126}$ Wiles (2007) 214; Carter (1987) 356. Frontisi-Ducroux (1995) 8 suggests that the masks found in the sanctuary are in fact slightly miniaturized versions of those worn by Spartan adolescents in a coming of age ceremony.

${ }^{127}$ Opinions differ on the antiquity of the Ortheia cult at Sparta. I follow Carter (1987) 355-383, who argues that the cult arrived with Phoenician travelers in the $8^{\text {th }}$ or $7^{\text {th }}$ centuries BC. See, however, Dawkins $(1929) 5-6,18-19,49$, who argues that the cult arrived with Dorian settlers in the $10^{\text {th }}$ century BC. Boardman (1963) 1-7 reevaluates the evidence and suggests that the cult was founded in the $8^{\text {th }}$ century, a date compatible with Carter's hypothesis (Carter 374). See also Des Bouvrie (2009) 153 and Kennel (1995) 135-136.

${ }^{128}$ See Kennel (1995) 79-80 for a concise overview.
} 
attempt to steal a cheese from Ortheia's altar and are whipped if they get caught. ${ }^{129}$ By the Hellenistic age, however, the flogging ritual has become a frightful endurance contest (karterias agōn), in which Spartan ephebes were flogged, sometimes until death, to see who could endure the greatest number of blows. ${ }^{130}$ By this point the rites of Ortheia also included a mock hunting competition and two musical contests besides. ${ }^{131}$ Already in the $6^{\text {th }}$ century, however, Ortheia's cult was a major part of state religion. ${ }^{132}$ Scholars have long debated what the purpose of such rituals may have been and what part the terracotta masks would have played in them; ${ }^{133}$ but they appear to have been worn in rites of passage for young Spartan boys and were perhaps used to enact a ritual drama or dance representing forces that posed a threat to society. ${ }^{134}$

The debates over the ritual purpose of the masks will continue, but what is of special importance to us here is their provenance. Based on a survey of archeological evidence from Near Eastern and Punic sites, Carter has suggested that the masks found in the sanctuary of Ortheia at Sparta are modeled on masks used in Phoenician cults. ${ }^{135}$ Despite their differing locations in the Near East and Mediterranean, such masks repeatedly appear in sanctuaries devoted to a male god, often associated with bulls, and his consort, a fertility goddess. In most places, the god and goddess should be identified as Baal Hamon and his consort Tanit, also known as Asherah. ${ }^{136}$ This goddess, however, is the Punic incarnation of Ishtar, the Semitic

\footnotetext{
${ }^{129}$ Xen. Lac. 2.9; Pl. Laws 633b 5-9.

${ }^{130}$ Cicero Tusc. 2.34, Hyg. Fab. 261, [Plut.] Inst. Lac. 40.239c-d. Kennel (1995) 149-161 reviews all the testimonia on the flogging contest.

131 See Woodward (1929) 288-290.

132 Kennel (1995) 137.

${ }^{133}$ Des Bouvrie (2009) 153-190 provides a thorough overview of various interpretations of the cult, and discusses the masks in particular on 164-5.

${ }^{134}$ Kennel (1995) 136-137; Frontisi-Ducroux (1995) 8. See also Des Bouvrie (2009) 164-5, who summarizes a variety of approaches, most of which suggest that the masks were used in rites of passage. See further Pettersson (1992) 46, 81-84.

${ }_{135}$ Carter (1987) 355-383. The survey of Near Eastern and Punic evidence may be found on pages 370-374.

${ }^{136}$ Carter (1987) 370-374. Cf. Stuckey (2003) 149.
} 
name for Inanna. ${ }^{137}$ Ortheia and her male companion, then, are figures parallel to the pairs of Near Eastern gods discussed by Halperin. Just as the fertility goddesses Inanna and Ishtar had their male companions (or paredroi) Dumuzi and Tammuz, so Ortheia had her male companion. ${ }^{138}$

Based on the similarity of the masks found at the Sanctuary of Ortheia to those in the tradition just described, Carter hypothesizes that the cult of the goddess at Sparta was founded by Phoenicians in the $8^{\text {th }}$ or $7^{\text {th }}$ centuries B.C.:

While the grotesque, furrowed face first appears in the first half of the second millennium B.C., the earliest known hero mask is from $14^{\text {th }}$-century Hazor. Thereafter, however, the traditions of the two types show very similar geographical and chronological patterns, and the distribution of the masks shows very clearly the routes of transmission. Canaanites adopted the use of masks from the Semitic culture of Mesopotamia and passed it to Cyprus before the end of the second millennium. The descendants of the Bronze Age Canaanites, whom the Greeks called Phoenicians, continued to use terracotta masks and took the practice with them when they traded and founded colonies in the western Mediterranean. In the course of trading and colonization, in the eighth or seventh century, Phoenicians introduced terracotta masks to Sparta. ${ }^{139}$

The goddess Ortheia, then, should be associated with Asherah-Tanit, and the mask of the hero with a male companion, who, as it happens, is associated with bulls or the pastoral life in some way. For, although bulls were most likely not themselves worshiped in the cult of Ortheia, ${ }^{140}$ Baal Hamon was associated with bulls, and bull iconography is a frequent feature of the sanctuaries where the masks are found, including the Sanctuary of Ortheia. ${ }^{141}$ The most likely candidate for Ortheia's male consort, argues Carter, following Marangou, ${ }^{142}$ is the pastoral hero Aristaeus:

${ }^{137}$ See Pettey (1990) 30-33 and Hadley (2000) 25 for summary of the same. Cf. Carter (1987) 376, 378, 383; Brill's New Pauly, s.v. "Tinnit."

${ }^{138}$ Carter (1987) 383.

${ }^{139}$ Carter (1987) 369-370.

${ }^{140}$ Carter (1987) 380.

${ }^{141}$ Carter (1987) 370-374, 380.

${ }^{142}$ Marangou (1972) 77-83. 
Several ivory reliefs from the Sanctuary of Ortheia depict a winged and bearded male. L. Marangou has persuasively argued that this winged man is Aristaios, son of Apollo and Cyrene, hero-god of herds and flocks, who taught men how to make cheese from milk, how to keep bees and take their honey, and how to cultivate the olive tree and extract its oil. The presence of Aristaios in Ortheia's sanctuary ought to mean that the Spartans associated the consort of Ortheia with this Greek deity of flocks and agriculture. ${ }^{143}$

Ortheia, then, descends from a fertility goddess of Phoenician origins, related to the west

Semitic goddess Asherah-Tanit, who is herself related to parallel traditions of the great Near-

Eastern fertility goddesses like Ishtar. Like Ishtar, Ortheia has a male companion, identified by scholars as Aristaeus. ${ }^{144}$ Considering Carter's hypothesis of Ortheia's Near Eastern provenance, it is notable that in Hesiod's Theogony Aristaeus marries the (Phoenician) daughter of Cadmus. $^{145}$

Other scholars agree with Carter that the masks of Ortheia show the influence of Phoenician models, ${ }^{146}$ and there is a body of evidence that indicates an abundance of contact between Greece and the Near East during the Archaic Age, which suggests that the transmission of Phoenician culture to Sparta is not at all implausible. Most broadly, Boardman has catalogued numerous instances of Near Eastern influence on Archaic Greek art. ${ }^{147}$ In connection with Ortheia in particular, Boardman agrees that the closest models for the masks associated with her cult are Phoenician and Punic. ${ }^{148}$ He also suggests that "an eastern craftsman working in Athens" may have been responsible for certain ivories found in that city and notes their similarity to

\footnotetext{
${ }^{143}$ Carter (1987) 382.

${ }^{144}$ For Aristaeus iconography at Sparta, see also Cook (1981) LIMC II.1 603-607, especially 606, where the Ortheia sanctuary is discussed, with Catalouge 9 and 20; Pipili (1987) 64 with notes 646-647. Simon (1995) 407-414 argues that winged men such as those in the Ortheia sanctuary instead represent Daedalus, but Alexandridou (2011) 65 aruges once again for Aristaeus.

145 Hes. Theog. 977; Carter (1987) 382.

${ }_{146}$ E.g. Falb (2009) 139-141; Larson (2007) 105; Hall (2007) 257; Boardman (1999) 77; Markoe (1985) 117-118.

147 Boardman (1999) 54-84.

${ }^{148}$ Boardman (1999) 77.
} 
ivories in the sanctuary of Ortheia. ${ }^{149}$ Some of the lead figurines dedicated to Ortheia also bear the hallmarks of Eastern influence. ${ }^{150}$ Fitzhardinge notes Syrian influence in terracottas from the Ortheia sanctuary. ${ }^{151}$ Markoe argues that Phoenician goods came to Greece by two routes, one of which touched at the southern Peloponnese. ${ }^{152}$ Hall notes that, during the Archaic period, "Phoencians regularly plied Greek waters," and cites the masks of Ortheia as an instance of their influence. ${ }^{153}$ Hall also discusses the possibility of Phoenician cultic influence in the Corinthia, because of the tradition of temple prostitution at a Corinthian sanctuary of Aphrodite, and the presence of an Isthmian cult to Melicertes, "a Hellenized form of the Phoenician god Melqart," a dying and rising god akin to the companion of Ortheia, as well as Baal, Adonis and Dumuzi. ${ }^{154}$ Herodotus (1.105) claims that Phoenicians founded the temple to Aphrodite in Cythera, which may have been the port of entry for Phoenician purple dye into Sparta, as Cartledge has suggested. ${ }^{155}$ Herodotus also posits that the Spartan colony on Thera supplanted a previous Phoenician settlement (4.147-8). In discussing the latter passage, Malkin argues that Thera did indeed have some sort of Phoenician background ${ }^{156}$ and goes on to suggest the likelihood that Phoenicians settled among local Greek populations as artisans and laborers of various sorts, bringing a number of cults with them (perhaps including Ortheia). ${ }^{157}$ A recent study by Hodos confirms that the cultural impact of the Orientalizing Revolution in Greece was more than material and artistic; Greeks also adapted Near Eastern tales and gods to their own local

\footnotetext{
${ }^{149}$ Boardman (1999) 62-63.

${ }^{150}$ Boardman (1999) 75-76. See also Wace (1929) 249-284.

${ }^{151}$ Fitzhardinge (1980) 49-50.

152 Markoe (1985) 126-127.

${ }^{153}$ Hall (2007) 257.

${ }^{154}$ Hall (2007) 258. On Melqart see Mettinger (2001) 83-111, 209-212, 217-220.

155 Cartledge (1979) 182.

156 Malkin (1994) 92.

${ }^{157}$ Malkin (1994) 94.
} 
contexts. $^{158}$

Granting that these contacts between Greece and the Near East are plausible, the degree to which a foreign tradition might have been incorporated into a Spartan context remains an open question. Carter argues for a thoroughgoing connection between Ortheia and the Phoenician fertility goddess. By her view, the goddess herself is imported from Phoenicia and maintains an independent identity, only syncretizing with Artemis at a much later point. ${ }^{159}$ Despite acknowledging Phoenician influence on the masks, some scholars have been more hesitant to follow Carter in identifying Ortheia as a Phoenician goddess. ${ }^{160}$ By this view, Ortheia's cult is originally Greek, but suffers Phoenican influence, perhaps only at a superficial level. There has likewise been debate about when Ortheia comes to be identified with Artemis. ${ }^{161}$ Carter argues for a late date of syncretization based on inscriptional evidence, since it is only under the Empire that Artemis and Ortheia appear together in Spartan inscriptions. ${ }^{162}$ Elsewhere, however, inscriptions link the two goddess beginning in the $5^{\text {th }}$ century, ${ }^{163}$ and many scholars press for a $6^{\text {th }}$ century date of syncretization based upon archaeological evidence. ${ }^{164}$ One need not pick a side in these debates to draw two conclusions. First, there was apparently Phoenician influence upon the cult of Ortheia at Sparta, whether one concludes that Ortheia is herself a Phoenician goddess, or that she is a Greek whose cult shows signs of Phoenician influence. Second, at some point, perhaps as early as the $6^{\text {th }}$ century BC, Ortheia becomes syncretized with Artemis.

How, then, does Artemis Ortheia relate to Daphnis and the origins of bucolic poetry? We

\footnotetext{
${ }^{158}$ Hodos (2006) 25-88.

${ }^{159}$ Carter (1987) 374-375.

${ }^{160}$ E.g. Falb (2009) 144, who notes the difficulty of the problem but does not choose a side; Kowalzig (Brill's New Pauly, s.v. Orthia) hardly takes account of Carter's research.

161 This is still an open question. See Falb (2009) 145.

162 Carter (1987) 375.

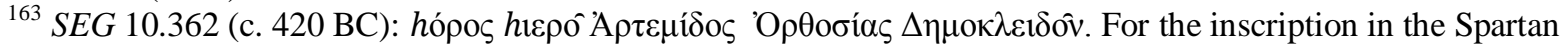
Sanctuary, see Woodward (1929) 285-377. Syncretization had certainly taken place by the time of Pausanias (2. 24. $5,3.16 .7)$.

${ }^{164}$ E.g. Falb (2009) 145, Larson (2007) 106.
} 
have already reviewed Daphnis' connection to figures like Tammuz/Dumuzi/Adonis, the herder figure and companion of the fertility goddess. It is clear that the male consort of Ortheia, here identified as Aristaeus, is another such figure. Daphnis and Aristaeus have many similar traits. Not only are Daphnis and Aristaeus both heroes, hunters, and herders, but they are both associated with Sicily as well. ${ }^{165}$ Carter herself noticed the similarity between Ortheia's paredros at Sparta and similar Near Eastern figures: "The pastoral nature of Aristaios corresponds well to Dumuzi/Tammuz, and it may be that Ortheia's lover was an early form of the Greek Adonis." 166 Artemis Ortheia's cult at Sparta, then, featured a male paredros parallel to Dumuzi/Tammuz/Adonis, the same type of figure from whom Berg and Halperin have argued that Daphnis descends. ${ }^{167}$ Instead of positing a vague connection between Daphnis and the Near East, therefore, I suggest that the cult of Artemis Ortheia provides a potential source for the origins of Daphnis, but in a Greek cultural milieu, with close connections to Doric Sicily. Daphnis originally played the same role in Sicily that Aristaeus did in Sparta: both were paredroi to Ortheia.

There is a further significance to be found in Daphnis' similarity to the consort of Ortheia: it explains the scholiastic focus on Artemis, which is otherwise perplexing yet unlikely to have been invented. That Ortheia came to be identified with Artemis is integral to understanding not only the stories reported in the scholia, but the genesis of Greek bucolic itself. The scholia insist upon the link between bucolic and Artemis, later echoed by Diodorus (4.84), who makes Daphnis the servant of the goddess. Ortheia, as has been argued, descends from a Semitic fertility goddess, worshiped together with her consort, who is associated with bulls and herding. Iconography depicting both bulls and the male consort (Aristaeus, in this incarnation)

\footnotetext{
165 Diodorus 4.82.5, where Aristaeus is said to have visited Sicily.

${ }^{166}$ Carter (1987) 383.

${ }^{167}$ See above, 26-46.
} 
appears at the Sanctuary of Ortheia in Sparta. I suggest that the scholia's insistence upon the cult of Artemis, like Diodorus' claim that Daphnis accompanied Artemis, is a vestige of Ortheia's influence on the cult and myth which becomes so fundamental to bucolic poetry.

Evidence from the cult of Ortheia at Sparta helps to explain another feature of the scholiastic tradition as well. In the second account, bucolic poetry is said to have arisen when Orestes brought the xoanon of Artemis from among the Taurians (ek Taurōn) to Rhegium and then to Tyndaris in Sicily. This is remarkably similar to other tales of the introduction of Artemis' statue from the barbarian wilds into Greek civilization, including that of Artemis Ortheia at Sparta. ${ }^{168}$ Like the wooden image of Artemis mentioned in the second account of the Theocritus scholia, Artemis Ortheia is supposed to have been brought by Orestes from among the Taurians (Paus. 3.16.7):

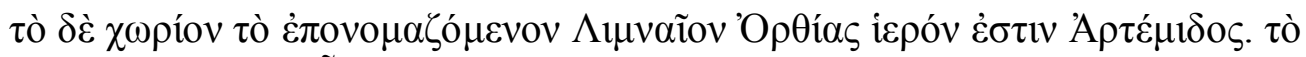

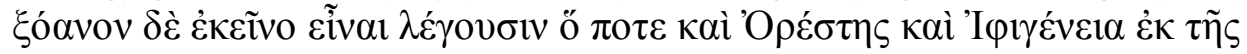

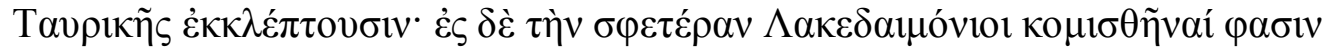

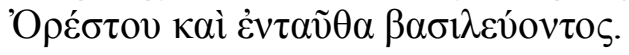

The place named Limnaeum (Marshy) is sacred to Artemis Orthia. The wooden image there they say is that which once Orestes and Iphigenia stole out of the Tauric land, and the Lacedaemonians say that it was brought to their land because there also Orestes was king. (trans. Jones, slight modification)

Although the author of the Theocritean scholia does not say it, the second tale of bucolic poetry's origins resembles the account of Ortheia's origin, but with Sicily as Orestes' final destination instead of Lacadaemonia. Not only, therefore, does the cult of Ortheia supply a likely source for the paredros figure of Daphnis, and help explain why the scholia focus on Artemis, but one of the anecdotes reported by the scholia about the genesis of bucolic repurposes the tradition about the arrival of Ortheia's cult at Sparta. The scholiastic theory thus connects bucolic poetry to the worship of the goddess in Sparta, a cult that originates in the Near East, and features a male

\footnotetext{
${ }^{168}$ Baudy (1993) 295 also discusses the similarity of these two traditions.
} 
paredros figure, like the figures to whom Daphnis has been compared by previous scholars. My theory of bucolic origins in the Spartan cult of Ortheia, therefore, unifies the Near Eastern model with the scholiastic tradition, and does so, moreover, in a way that locates Daphnis in his Doric and Sicilian context. Daphnis arrived in Sicily as part of Ortheia's entourage and would perhaps have figured in the festivals of Artemis that the scholia commemorate, perhaps celebrated as the companion of the goddess, as he is in Diodorus (4.84). It is to this cultural context that Theocritus alludes in making Daphnis the central figure of Idyll 1 and the symbol of the bucolic mode as a whole.

That traditions associated with Ortheia's cult may have spread outward from the vicinity of Sparta is not surprising, a point addressed in detail at the end of the chapter. ${ }^{169}$ Ortheia was an immensely popular goddess whose rites were distinctively Spartan and of civic importance. Her role in initiation was especially important in cementing the bonds between Spartan youth and the larger community. ${ }^{170}$ It is unsurprising that traditions associated with a festival of such importance and popularity, so connected with civic and individual identity, should have become influential elsewhere in Sparta's "sphere of influence." 171 The Messenians appear to have adopted Ortheia for themselves. ${ }^{172}$ Masks of the goddess dating from the sixth century have been discovered at Thera, a Spartan colony, as well as Tarentum and Samos, while accounts and inscriptions indicate that her cult was present at Attica, Argos, Epidauros, Arcadia, Elis, Megara, Boiotia, and Byzantium. ${ }^{173}$

The establishment of cults from mainland Greece by travelers and colonists was one

\footnotetext{
${ }^{169}$ See pages $60-65$.

${ }^{170}$ Parker (1989) 148; Kennel (1995) 135, 137.

${ }^{171}$ Carter (1987) 359. Samos was not a Spartan colony, but the two cities did have a special relationship. See Cartledge (1982) 243-265.

${ }^{172}$ Luraghi (2008) 134, 166. See also below, 62-65.

${ }^{173}$ Carter (1987) 359, 375 n.102.
} 
method of self-definition within new cultural contexts while simultaneously maintaining a connection to their places of origin. Just as Greek religion was inseparable from polis identity, the designation of sacred spaces was essential to the physical delineation of a colony, creating a bond between the colonists and their new location: ${ }^{174}$ "For the most part, cults of colonies were imported," bringing familiar deities into an unfamiliar space, and establishing a sense of colonial identity bound to the new location. ${ }^{175}$ An excellent example of such activity may be found at Syracuse. The oikist of Syracuse, the Corinthian Archytas, received an oracle at Delphi relating to his future colony. "A certain Ortygia lies in the misty sea above Thrinakia, where the mouth of Alpheios bubbles, mixing with the springs of fair-flowing Arethousa" (trans. Larson 2001). The Alpheius was thought to flow beneath the ground in Elis, but the oracle makes it reemerge in Sicily, on Ortygia, which was sacred to Artemis. Artemis had shrines associated with the Alpheius back in Elis, including at Olympia. The river's apparent re-appearance on the island of Ortygia, then, contextualizes the new landscape in terms of mainland geography and religion, defining the cultic identity of Syracuse in terms of previous sacred sites. ${ }^{176}$ The foundation story of Archias in Syracuse is characteristic of similar stories, in which the oikist receives an oracle containing a prospective site for colonization, thus furnishing him with Delphic legitimacy. ${ }^{177}$ "The oikist may be described as the link, the intermediary between the mother-city, the colonists, the potential colony, and the god."178

Stories of the migration of mythical figures from one location to another could serve a similar purpose. Sourvinou-Inwood has discussed the role that stories of the offspring of nymphs mating with gods could play in colonial ideology. For instance, Apollo abducted the nymph

\footnotetext{
${ }_{175}^{174}$ Malkin (1987) 138-139, 185, 202. See also Sourvinou-Inwood (2000) 13-37, especially 16-17.

${ }^{175}$ Malkin (1987) 185.

177 Malkin (1987) 41-43, 88-89.

${ }^{178}$ Malkin (1987) 88-89.
} 
Cyrene from mainland Greece, in Thessaly, and brought her to Libya, where she bore their son, Aristaeus, and where she became the eponymous protector of the city Cyrene.

Nymphs were rooted in their locality. Cyrene, as a result of the actions of a god, migrated from a Greek locality to Libya and became rooted there, thus creating an antecedent of, and ideological legitimation for, the foundation of the colony, which becomes symbolically rooted in the locality through its protecting Nymph, who is both Greek like them, and rooted in the local landscape. ${ }^{179}$

As the consecration of Ortygia to Elean Artemis in Syracuse connects the landscape of the colony back to that of the mainland, it is a Thessalian nymph that becomes the eponymous figure of Cyrene. Myth and cult concerned with Artemis Ortheia may have played a similar role in various Sicilian locations where colonists would have adapted this popular cult of high civic importance to their new landscapes, helping to root unfamiliar locales in the context of mainland Greece.

\section{ARTEMIS ORTHEIA ON SICILY}

Until now, the main emphasis of my argument has been to demonstrate that the cult of Artemis Ortheia in Sparta included the worship of a male paredros, and that Daphnis is the Sicilian version of that paredros. But the specific avenues by which Ortheia and her male companion may have become a part of a Sicilian religious context remain to be addressed. In the final part of this chapter, therefore, I would like to suggest two possible routes by which the Ortheia cult may have arrived in Sicily. As has been discussed, the cult appears to have spread into areas under Spartan influence or control, so any one of those locations that also had close contact with Sicily is a conceivable conduit.

One possible route would put Ortheia on Sicily from a very early date. The cult of Artemis on Ortygia in Syracuse, which appears to date from the foundation of Syracuse, has

\footnotetext{
${ }^{179}$ Sourvinou-Inwood (2005) 114.
} 
already been mentioned. ${ }^{180}$ That cult appropriates landscape and traditions from Elis on the Greek mainland and adapts them to the new Sicilian landscape: the river Alpheius, associated with Artemis in Elis, is said to dive underground and reemerge at the Ortygian spring of Arethousa. ${ }^{181}$ The cult of Ortheia is also known to have been present in Elis. ${ }^{182}$ Moreover, a story about Artemis' flight from the river Alpheius includes details that are strikingly reminiscent of the masks used in Ortheia's cult (Paus. 6.22.9):

Alpheius fell in love with Artemis, and then, realizing that persuasive entreaties would not win the goddess as his bride, he dared to plot violence against her. Artemis was holding at Letrini an all-night revel with the nymphs who were her playmates, and to it came Alpheius. But Artemis had a suspicion of the plot of Alpheius, and smeared with mud her own face and the faces of the nymphs with her. So Alpheius, when he joined the throng, could not distinguish Artemis from the others, and, not being able to pick her out, went away without bringing off his attempt. (trans. Jones)

Walter Burkert reads the detail of Artemis smearing her face with mud as "a reflection of the ritual use of such masks" as appear in the sanctuary of Ortheia at Sparta. ${ }^{183}$ To summarize, the founder of Syracuse connects Ortygia in Syracuse back to the Alpheius river, which is an emblem of the transfer of Artemis' Elean cult to Syracuse; Artemis Ortheia was known to be present in Elis; lore connected with Artemis' Elean cult suggests the ritual use of masks. For all these reasons, Artemis' cult on Ortygia provides one plausible means by which traditions related to Ortheia may have traveled to Sicily. Importantly, Arethousa, the spring on Ortygia said to be the location of Alpheius' re-appearance, features in Idyll 1 (117), where Daphnis calls it by name to bid farewell. If Artemis' Ortygian cult was the source or one source of Daphnis' arrival on Sicily, then his appeal to Arethousa would allude to that connection.

\footnotetext{
${ }^{180}$ Pages 59-60.

181 See above, page 59.

182 Carter (1987) 375n.102; Mejer (2009) 64; Scholia to Pindar Ol. 3.54a.

${ }^{183}$ Burkert (1985) 104. Note, however, that Burkert considers the masks to be portraits of ugly old women, a view that Carter (1987) rejects.
} 
There is another scenario, however, which, besides being plausible, also gains support from the second of the scholiastic hypotheses, which proposes that Greek bucolic poetry originated when Orestes brought the xoanon of Artemis from among the Taurians, first to Rhegium, and then to Tyndaris, where the locals are said to have sung hymns to Artemis. This second anecdote regarding the origins of bucolic poetry is very similar to the myth of Artemis Ortheia's arrival in Sparta, as discussed above. ${ }^{184}$ But the story of Orestes' arrival at Tyndaris is also important because it provides evidence for Artemis Ortheia's presence on Sicily along with the myth and ritual that would go on to influence Greek bucolic poetry.

Tyndaris, on the north coast of Sicily, was founded in 396 BC by Dionysius I of Syracuse as a buffer against the Carthaginians. Dionysius populated the town with settlers relocated from Sicilian Messene (originally known as Zancle), on the straits across from Rhegium. These Sicilian Messenians were not originally from Sicily, but from Messene in the Peloponnese, where they had been subjugated by Sparta. After the revolt of 464 BC, the Athenians settled the Messenians at Naupactus (Thuc. 1.101.2-103.3; Diod. Sic. 11.63.1-64.4), from which they fled following the Peloponnesian War (Paus. 10.38.10; Diod. 14.78.5-6), and it was members of this group who settled first in Sicilian Messene and then founded Tyndaris (Diod. 14.78.5; Brill's New Pauly, s.v. "Tyndaris"). Nor was the settlement of Tyndaris by refugees from Sicilian Messene the first instance of contact between Messenians and Sicily. Anaxilaus, tyrant of Rhegium (494-76), had called the Messenians to his aid in defeating the inhabitants of Zancle. Following the defeat of that city, the Messenians settled there and changed the name (Hdt. 6.23; Thuc. 6.4.6; Diod. Sic. 15.66.5). Thus, Messenians who originally hailed from the Peloponnese came into contact with Sicily on at least two occasions: the first migration in the reign of Anaxilaus (494-76), the second following their expulsion from Naupactus, and culminating in

${ }^{184}$ Page 57. 
the founding of Tyndaris (396). ${ }^{185}$

Given the geographical proximity of the two peoples, it will come as no surprise that the Messenians and Spartans shared certain religious rites and mythology, including traditions about Ortheia. Strabo 8.4.9 offers evidence of a shared culture between the two groups:

The temple of Artemis at Limnai, at which the Messenians are reputed to have outraged the maidens who had come to the sacrifice, is on the boundaries between Lakonia and Messenia, where both peoples held assemblies and offered sacrifice in common; and they say that it was after the outraging of the maidens, when the Messenians refused to give satisfaction for the act, that the war took place. And it is after this Limnai, also, that the Limnaion, the temple of Artemis in Sparta, has been named. (trans. Jones)

The temple of the goddess was held jointly, on the boundary of the two lands. There are good reasons to identify Artemis of Limnai (Artemis Limnatis) with Artemis Ortheia. The temple at Limnai, says Strabo, gives its name to the Limnaion in Sparta; the Limnaion, in turn, is the location of Ortheia's temple, as demonstrated by Pausanias 3.16.7: "The place named Limnaion (Marshy) is sacred to Artemis Orthia[...]” (trans. Jones). ${ }^{186}$ "The Artemis Limnatis of Volimos [in Messenia] appears to be an alter-ego of the quintessentially Spartan Artemis Orthia."187 The Messenians have adopted the cult of Ortheia for themselves.

The adoption of Ortheia by the Messenians explains why the second scholiastic theory of bucolic's origins states that Orestes stopped at Rhegium before proceding to Tyndaris: both locations had received influxes of Messenian settlers; indeed, Tyndaris was founded by Messenians. It is clear that the Messenian appropriation of the Spartan cult of Ortheia predates

\footnotetext{
185 The history of the Messenians in the West is extremely complicated. Thucydides (6.4.6) does say that Anaxilaus changed the name of Zancle to Messene, and says he did so because he considered Peloponnesian Messene to be his homeland. Thus, the Messenian identity is clearly important to the foundation of Sicilian Messene. However, he also reports that the population that settled there was "mixed." The population of newly founded Sicilian Messene, then, may not have been composed entirely of Messenians (see Luraghi [2008] 152). On the other hand, the city did identify itself as Messenian in a number of ways in addition to its name (Luraghi [2008]162-164). Indeed, the colonists of Tyndaris from Sicilian Messene would construct a Messenian identity for one of their cults (Luraghi [2008] 166). See below.

${ }_{186}$ Luraghi (2008) 134; see also 45, 123-124, 236-237; Rose (1929) 400.

${ }^{187}$ Luraghi (2008) 134. See also 166.
} 
the Messenian flight, since Messene's outrage at the temple is given by the Spartans as justification for the Messenian War (Strabo 8. 4.9). As Luraghi has pointed out, Tyndaris is a young town (founded in 396), yet the story of Orestes' arrival there and his introduction of the Ortheia cult stretches back into deep antiquity. ${ }^{188}$ The Messenians are inventing their own history, basing the traditions of their relatively new town upon those absorbed from the Spartans. ${ }^{189}$

The Messenian migration to Sicily appears, therefore, to furnish one very plausible occasion on which the Ortheia cult and its attendant mythology may have made its way to Sicily. Moreover, the proposed route conforms to one of the accounts provided in the scholia to Theocritus. The Messenian settlement need not be the first nor only time that traditions associated with Artemis Ortheia arrived on Sicily, but it is clear that traditions about the goddess made their way to the island in time for adaptation by the new inhabitants of Tyndaris. We cannot say with any certainty whether traditions about Ortheia would have traveled with the first Messenian influx or the second, or with both. It is possible that Messenian settlers may have brought these traditions with them when they settled Zancle after their mercenary mission for Anaxilaus at Rhegium. It is even possible (though extremely unlikely) that the Messenian settlers only encountered stories of Ortheia once they had already traveled to Sicily, and then retrojected such tales into myths of Tyndaris' early history. It is worth noting, however, that the scholiast pays particular attention to Tyndaris; he says that Orestes stops off in Rhegium, but only in Tyndaris are songs bucolic hymns composed for Artemis. Therefore, the Messenian migration to Tyndaris should perhaps be considered a major event in the genesis of Greek bucolic poetry. At a minimum, the scholiastic notice demonstrates that the cult of Artemis Ortheia at some point

\footnotetext{
${ }^{188}$ Luraghi (2008) 237.

${ }^{189}$ Luraghi (2008) 236.
} 
arrived on Sicily, and that the story of her advent was available to the Messenians, to be repurposed in the foundation story of their local cult at Tyndaris. The Messenian migration from the Peloponnese to Sicily offers a concrete scenario by which the Near Eastern paredros became associated with a Doric Greek cult, and came to influence the genesis of Greek bucolic poetry on Sicily. Such a theory also justifies, moreover, the ancient scholarly interest in popular festivals to Artemis.

\section{CONCLUSION}

Idyll 1 embodies Theocritus' poetic project, dramatizing the legendary beginnings of bucolic song with its refrain, thereby initiating the new literary genre of bucolic song. To understand what the Muses are being called upon to create when Thyrsis repeatedly invokes their aid in his rendition of the Sufferings of Daphnis, it is essential to know who Daphnis is. Based on the notes and anecdotes found in ancient scholars, we could already assume that Daphnis was the legendary creator of bucolic and that he came from Sicily. We could also assume, with many other scholars, that certain aspects of the bucolic Idylls, such as song exchange and the use of proverbs, were drawn from the popular sphere. ${ }^{190}$ The theory articulated here, however, is the most specific and, I believe, plausible account of Daphnis' origin yet proposed.

First, it may be concluded that Daphnis is indeed of Near Eastern origins, and that those Near Eastern origins are essential to understanding his nature as a paredros. At the same time, however, a Near Eastern provenance should not distract from Daphnis'staunchly Doric affiliations. His more proximate genesis is in the cult of Artemis Ortheia at Sparta, a quintessentially Spartan cult, which is known to have spread to numerous places around the

${ }^{190}$ See for instance Cipolla (1979); Horowski (1973); Petropoulos (1959); Merkelbach (1956); Caberghs (1944); Di Mino (1931). 
Greek world, including, as the scholia to Theocritus attest, to Sicily. Thus, Daphnis is not just a replica of Adonis, as some scholars propose. ${ }^{191}$ Daphnis is not some recent borrowing from the Near East, nor even from the Punic settlements on Sicily, where the worship of paredroi is well attested. ${ }^{192}$ Instead, he is the key example of local Sicilian tradition in Idyll 1, a poem which repeatedly invokes the Sicilian landscape and dramatizes the oral transmission of a song by an ostensibly popular figure, the shepherd Thyrsis. Theocritus' first Idyll is about being rooted in local geography and local tradition: a Sicilian shepherd sings in a Sicilian mode about a Sicilian hero bidding farewell to the island of Sicily. Moreover, as we shall see further in Chapter 2, if Daphnis did not have his strong Doric, Sicilian pedigree, Idyll 1 would be stripped of the bulk of its poetic weight.

We may also conclude that Daphnis emerged from and evokes the Sicilian popular festivals mentioned by the scholia, which featured performances by agroikoi of popular Sicilian songs in honor of Artemis. In Diodorus' portrait of Daphnis (4.84), the herder pleases Artemis with his rustic songs. Daphnis finds his real world analogues in these rustics singing to the goddess at her festivals, which Theocritus invokes by dramatizing in the ballad of Thyrsis a living, oral-traditional performance. The likelihood that Daphnis was associated with such festivals connects not only Idyll 1 but the bucolics as a whole to an atmosphere of civic importance and collective identity.

Moreover, and perhaps most importantly, Idyll 1 draws an analogy between Theocritus' metaphorical initiation of bucolic poetry in the refrain of Thyrsis and the popular, local figure

\footnotetext{
${ }^{191}$ Halperin (1983a) 200.

192 One might conceivably object that the theory presented here is too complex, and that it would simpler to imagine that cults of Aphrodite on Sicily were influenced by Punic cult at Eryx or similar locations. Myths about Aphrodite and her consort could easily have made their way thence into bucolic poetry. However, the insistence of the scholiastic tradition upon Artemis' connection to the genesis of Greek bucolic makes the cult of Ortheia a stronger candidate, since Ortheia syncretizes with Artemis. Without the cult of Ortheia, there is no way to explain the scholiastic obsession with Artemis.
} 
that the song memorializes and celebrates. Yes, such an embrace will always be to some extent ironic - a high literary poet is not likely to adopt the voice of a shepherd without delighting in the tension that arises from such an act. But the rhetorical value of that embrace is immense, especially for a poet who refers frequently to his own Sicilian and Doric origins elsewhere. ${ }^{193}$ Theocritus, in writing the dramatization of the oral tradition that Thyrsis represents, sings with the voice of Daphnis, of the herder, of popular cult: in the midst of an increasingly Alexandrian, Pan-Hellenic age, Theocritus initiates a new mode of poetry on behalf of Doric Sicily and draws an ideological equation between his own high, literary work and local, vernacular tradition.

${ }^{193}$ At Id. 11.7 Theocritus makes reference to his own Sicilian origins. Sicily, Syracuse or Doric Identity are topics of note, among other places, in Id.15.87-95; 16.76ff; Ep. 18. 


\section{Chapter 2: \\ Idyll 1: Daphnis and the Poetics of Locale}

\section{THE MYSTERY OF THYRSIS' SONG}

What we know about the events of Thyrsis' song could be summarized as follows. Daphnis dies as a result of love, "wasting away" in a manner that may recall the traditional suffering of the lover $(66,82,88,91) .{ }^{194}$ The natural world of Sicily mourns $(71-75)$ as Daphnis receives a series of visitors: Hermes (77-78) and various groups of herdsmen (80-81) ask the dying cowherd about the nature of his love; then comes Priapus with the information that a girl searches for Daphnis over hill and dale; he wonders why the herder will not accept this readily available love (81-91). For reasons left mostly unstated in the poem, Daphnis is unable to accept the love of the girl who pursues him $(81-91,97-98,103)$. Instead, the poet allusively notes that

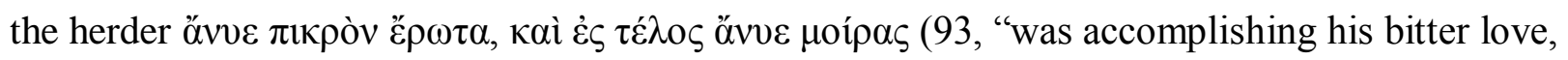
and was accomplishing his fate"), which seems to refer to the herder's impending death on account of love, although the larger circumstances of his behavior remain unclear. Daphnis' final visitor is the goddess Aphrodite, who claims that the Sicilian herdsman had sworn to get the best of love, but that love had won out in the end (97-98); once again, the nature of Daphnis' love remains unknown. Daphnis issues a series of mysterious rebukes to Aphrodite and claims he will continue to cause pain to love, even in the underworld (100-113). Thereupon he bids farewell to Sicily, along with its flora and fauna, as well as Pan (115-136). The cowherd blames love explicitly for his impending doom (130), which he claims will turn the natural world upside

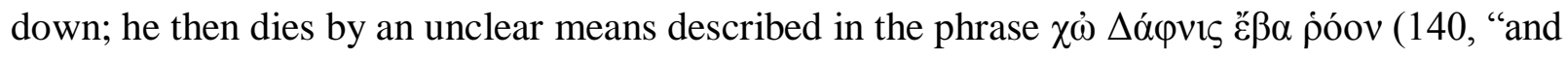

\footnotetext{
${ }^{194}$ Hunter (1999) 63, 91.
} 
Daphnis went into the stream"). ${ }^{195}$

The difficulty of interpreting these events lies in part in the apparently purposeful allusiveness of the author. ${ }^{196}$ The poet seems to assume an audience that is more or less familiar with his narrative, and therefore leaves out important details. Among narrative details that we are lacking, but which are in all likelihood essential to understanding the context and meaning of Thyrsis' song: whom does Daphnis love? Who is the girl in pursuit of Daphnis, and why is it that the herder cannot satisfy his desire for love with her? What is the source of Daphnis' hostile relationship with Aphrodite and Eros? Why does Daphnis die? Idyll 1 raises all of these questions, but offers no easy answers.

Rather than offering hints to the perplexed reader, the song of Thyrsis seems to revel in its own difficulty: indeed, the characters of Thyrsis' song themselves pose the questions listed here (77-91). Thyrsis — and Theocritus, then — deliberately draw attention to the mystery and complexity of Daphnis' character and motivations, suggesting that it may be a fool's errand to attempt a full explication of the narrative, context, and meaning of Daphnis and his actions. Theocritus himself, by dramatizing the befuddlement which Daphnis causes in the very song that takes up his behavior, may be acknowledging the impossibility of really understanding this mythical figure, a figure who, as I have argued and will continue to argue here, is patterned on narrative models sunk deep in literary and religious traditions of the Near East. ${ }^{197}$ We must consider the possibility that Theocritus chose to dramatize the story of Daphnis precisely because of its mysteriousness and its resemblance to narratives of deep antiquity, which make it simultaneously familiar and impossible to understand.

\footnotetext{
${ }^{195}$ Instead of being blinded, as reported by several ancient sources, e.g. Diodorus (4.84), Timaeus in Parthenius (Narr. Ama. 29), Aelian (VH 10.8).

${ }^{196}$ So Hunter (1999) 63.

${ }^{197}$ See Chapter 1.
} 
Unearthing the meaning of such an allusive story requires looking for parallel treatments of Daphnis and figures similar to him. Daphnis is mentioned by in a number of other texts apart from Idyll 1, and these sources report a fairly consistent narrative tradition, with Sicilian origins dating back at least to the time of Theocritus. ${ }^{198}$ Representative is Diodorus 4.84:

In the Heraean mountains [SE Sicily, inland from Syracuse], so the story goes, was born Daphnis, a son of Hermes and a nymph, and he, because of the bay

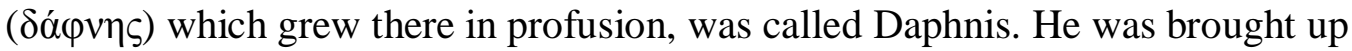
by the nymphs, and possessed very many herds of cattle which he tended very carefully. For this reason he earned the name 'Boukolos'. He was a naturally gifted musician and invented bucolic poetry and song ( $\mu \varepsilon \dot{\lambda} \lambda \mathrm{s}$ ), which persists throughout Sicily to the present day. The story is that Daphnis hunted with Artemis and found favour with the goddess, and that he delighted her exceedingly with his syrinx playing and bucolic singing (ßо৩ко $\lambda 1 \kappa \tilde{\varsigma} \varsigma \mu \varepsilon \lambda \omega \delta i \alpha \varsigma)$. They say that one of the nymphs fell in love with him and warned him that, if he slept with another woman, he would lose his sight. A king's daughter made him drunk and he slept with her, whereupon he was blinded in accordance with the nymph's warning. (translation Hunter [1999] 64-65)

Unfortunately, the simple outline reported by Diodorus is difficult to reconcile with the events of Idyll 1 itself, leading Gow to conclude that the narrative transmitted by Diodorus and others has nothing to do with Idyll $1 .{ }^{199}$ Certainly, Diodorus' account raises a number of questions. Is the girl in pursuit of Daphnis in Idyll 1 the same as the princess here? Does the nymph of Diodorus' narrative figure at all in the song of Thyrsis? Why is Daphnis blinded in Diodorus' account, but not in the song of Thyrsis? What about Aphrodite? Why does she figure so prominently in Idyll 1, but not at all in the mythographical account? Artemis' presence in Diodorus and the scholia but her absence from Idyll 1 also needs to be explained. If Daphnis is associated with Artemis in both Diodorus and the scholiasts, as shown in Chapter 1, why is she not present in Idyll 1 itself?

I will address these narrative difficulties of Thyrsis' song by examining the various

\footnotetext{
${ }^{198}$ So Hunter (1999) 64.

${ }^{199}$ Gow (1952) 2.2.
} 
accounts of Daphnis, beginning with that of Theocritus, as well as the stories of mythological figures related to Daphnis. It is my hope that the historical theory of origins proposed in Chapter 1 will provide a useful background against which to analyze the evidence, and that this new context will lead to interpretive insight, both of the narrative of Thyrsis' song and some of its more unusual formal elements. Despite these wide variations in provenance of these narratives, the parallels to be adduced here share a narrative type with the story of Daphnis, in which a female deity or the proxy of that deity seduces or attempts to seduce a mortal male; frequently the female places an injunction upon the male; whether the seduction succeeds or fails, the male is then destroyed by the this erotic contact; frequently the destruction comes as retribution for breaking the injunction. As Burkert has rightly noted, narratives of this sort are common not only in ancient Greece, but in Near Eastern traditions as well. ${ }^{200}$ Most importantly to the analysis of Idyll 1, many of the figures who share this narrative are the very mythical figures whom Berg and Halperin have already identified as "forebears of Daphnis," as discussed in Chapter $1 .{ }^{201}$ Here I aim to develop these parallels further in order to shed light upon the confusing narrative lurking behind Idyll 1. In addition, building on the historical account of bucolic's origins laid out in Chapter 1, I hope to demonstrate that Daphnis was part of a thriving community of related mythological figures worshipped on Sicily; only by understanding Daphnis simultaneously as part of this community and distinct from it is it possible to comprehend the full significance of his role in the programmatic first $I d y l l$.

\section{The Song of Thyrsis}

A primary difficulty in the interpretation of Thyrsis' song is that we join the narrative in

\footnotetext{
${ }^{200}$ Burkert (1979) 111.

${ }^{201}$ Berg (1974) 13, 17-20; Halperin (1983a) 183-200.
} 
medias res, or rather at the tail end of what is clearly a larger narrative: Theocritus focuses his attention in Idyll 1 only on the final episode of the story of the legendary herder, namely, the algea Daphnidos. ${ }^{202}$ The poet's narrowed focus makes it more difficult to understand how Thyrsis' song maps onto the Daphnis story as we know it from other sources. Theocritus' ballad of Daphnis' death constitutes only the very last detail reported Diodorus and the other ancient sources, namely, the destruction of the herder. If the account in Idyll 1 only presents the end of Daphnis' life, with tantalizing hints of what led to his death, we must assume that Theocritus is pointing towards a larger narrative

Thyrsis' narrative strategy raises immediate questions. We might have expected his song to begin with a clear explanation of why Daphnis was dying, of what and who was responsible for driving him to his death. Instead, Thyrsis begins by describing the groups of mourners, human and otherwise, that come to lament for Daphnis (a point to be addressed in greater detail later on), and then describes the series of visitors that dying herder receives: first Hermes, then various types of herders, Priapus and finally Aphrodite. This series of visitors might have explained what exactly causes Daphnis to suffer and die. Instead, the questions that Hermes, the herders and Priapus pose only serve to increase the mystery of Daphnis' fate, since each of these visitors, except for Aphrodite, is almost as perplexed as the modern reader about Daphnis' strange behavior. ${ }^{203}$

The questioners possess varying levels of knowledge. First comes Hermes, who knows that Daphnis is in love, and that this love is "wearing Daphnis down." But the god's knowledge does not extend beyond these bare facts (77-78). Three types of herders, of cows, sheep and goats, form the second group of visitors. As perhaps is fitting to their mortal status in comparison

\footnotetext{
${ }^{202} 1.19,5.20$. See also Hunter (1999) ad loc.

203 1.71-98. See above, 68-71.
} 
to Daphnis' other visitors, who are all divine, the herders cannot even begin to comprehend what is causing Daphnis' grief. All they understand is that Daphnis is suffering some sort of evil fate,

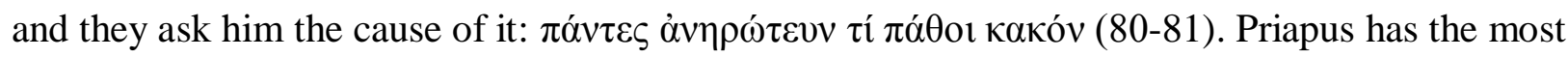
definite knowledge of the visitors before Aphrodite, but it amounts to little more than what Hermes knew. The rustic god, too, knows that Daphnis is in love, and chides the herder for

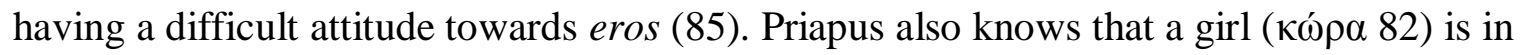
pursuit of Daphnis. In an appropriately rustic and proverbial passage, Priapus appears to chide Daphnis for not taking the opportunity to satisfy his desire with the girl, despite the fact that she follows him over hill and dale. But Priapus is evidently perplexed by Daphnis' behavior; we do not learn from the rustic god why Daphnis avoids the girl, or who she may be (although his language may imply a deeper knowledge of Daphnis' story than is immediately clear, as we will discuss momentarily). Thyrsis very pointedly tells us that Daphnis responds to none of the

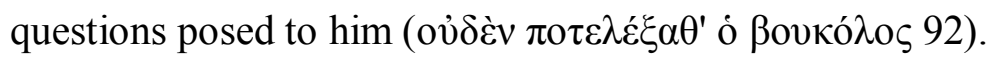

These questions are at the heart of the narrative complexity of Thyrsis' song. Understanding the identity of this girl and why she pursues Daphnis may allow us in turn to understand the narrative behind the mysterious events of the Idyll itself, and how the narrative to which Priapus refers corresponds to that reported in the other sources. What Priapus says matches with the story that we know from sources outside the Idyll (81-93):

$$
\text { ทे } v \theta^{\prime} \text { ó Прín } \pi \text { os }
$$

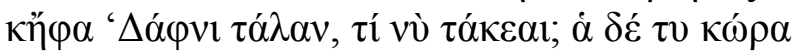

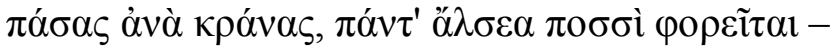

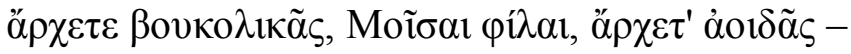

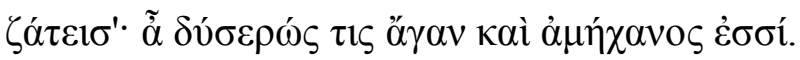

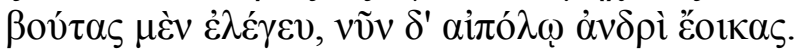

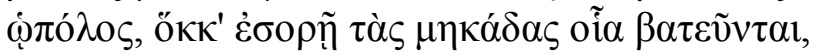

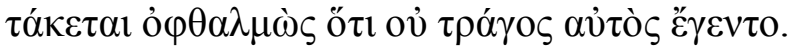




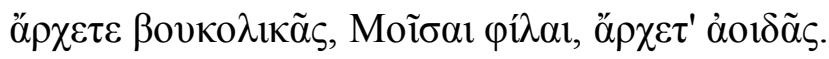

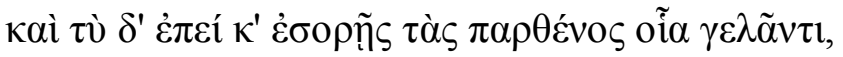

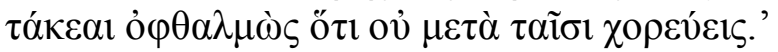

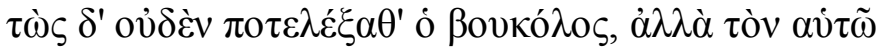

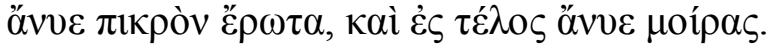

Priapus came and said 'Wretched Daphnis, why are you pining? A maiden is borne afoot over every peak and thorough every glade'

Begin, dear Muses, begin the bucolic song-

'searching for you. You truly are someone bad at love and helpless. You used to be called a neatherd, but now you are like a goatherding man. The goatherd, when he sees how the she-goats are mounted, weeps that he was not born a billy goat.

Begin, dear Muses, begin the bucolic song.

And you, when you see how the maidens laugh, you weep that you do not dance with them.' To this the neatherd made no response, but was accomplishing his bitter love, and was accomplishing his fate.

Once again, it is clear that Priapus knows that Daphnis is in love. But it is not clear, at first, if Priapus knows whom Daphnis loves. This ambiguity stems from the word кóp $\alpha$ in line 82, which could refer to a mortal girl, but could also, conceivably, refer to a nymph. ${ }^{204}$ This ambiguity of language is problematic, since we know from Diodorus and the other sources that

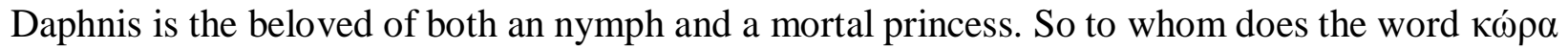
refer? Who is it that is pursuing Daphnis over hill and dale?

The rest of Priapus' speech provides an answer. As strange as Priapus' proverbial response to Daphnis' predicament is, its central point is about finding a love match appropriate to one's position in the hierarchy of things. Priapus compares Daphnis to a goatherd, who watches as the billy-goats mount the nannies, and wishes that he himself had been born a billy. In equating Daphnis' refusal of his eager suitor with the goatherd's desire for a mismatched sexual

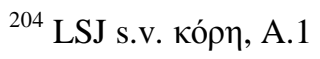


encounter, Priapus seems to hint that Daphnis, too, is guilty of not seeking a lover of his own kind. If this is indeed part of his message, then it seems likely that the $\kappa \omega ́ p \alpha$ in pursuit of Daphnis is in fact the mortal princess, who would be a much more appropriate match for him in cosmological terms than the nymph, a divinity.

This interpretation is further supported by what Priapus goes on to say, namely, that when Daphnis looks at all the maidens dancing, he despairs at not being able to dance with them (9091). Priapus mentions this scenario as a parallel to the goatherd's longing to be a goat. The equivalence lies in the fact that both men long to make love, but restrain themselves. The goatherd longs (inappropriately) to be a goat; Daphnis longs to dance with the mortal maidens, but (inappropriately) prevents himself from doing so. The lesson in both cases is to choose the lover who is appropriate to your station - neither beast, as in the case of the goatherd, nor divinity, as in the case of Daphnis. He ought instead to yield to the requests of the $\kappa \omega ́ \rho \alpha$, apparently a mortal woman and therefore appropriate to Daphnis. Priapus believes that Daphnis wants to do this, as indicated by his acknowledgement that his refusal to do so is causing him a lot of pain. Priapus points to the story of Daphnis and the nymph by omission, but does not possess a full understanding of the events that lie behind Daphnis' behavior; even if the god is aware that Daphnis for some reason refuses the mortal girl on account of the nymph, he still does not understand why Daphnis would flee from a woman who clearly wants to be his lover. Despite his incomplete knowledge of the background narrative, Priapus' rebuke of Daphnis corresponds well to the narratives reported by Diodorus and the other sources. There are two females in love with Daphnis, one a mortal girl, and one a nymph. Priapus urges Daphnis to love the mortal girl, who is appropriate to his status as a mortal male.

So what, in sum, do we know about the girl in pursuit of Daphnis? We know that she is in 
love with Daphnis, and that she pursues him over hill and dale to consummate that love. On the basis of the mythological sources and Priapus' speech, we may also assume that this anonymous girl is mortal and that she is, at least in some sources, the daughter of a king. We may also be able to assign her a name based on evidence drawn not from external evidence, but from elsewhere in the Idylls themselves. Theocritus mentions the story of Daphnis in another context, at Idyll 7.73, where two herders sing about the circumstances at the heart of Idyll 1. In this case, however, Theocritus supplies the name of the girl with whom Daphnis is enamored as Xenea: ๓̋

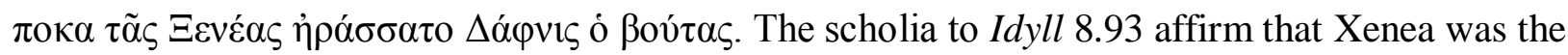
name of the mortal princess beloved of Dapnnis. ${ }^{205}$ Theocritus' name-dropping in Idyll 7 signals that he is aware of a larger story about Daphnis, a story that he for some reason avoids sketching out in full detail. It is also surely relevant that when Theocritus mentions Daphnis and Xenea in Idyll 7, it is in a programmatic mise en abyme, where the story of their love will be the musical accompaniment to Lycidas' imaginary, and therefore idealized, bucolic feast. In both Idylls, the story of Daphnis' fateful death takes center stage, first in the prototypical bucolic tale, then in Lycidas’ pastoral fantasy.

None of the male characters who visit Daphnis in the song of Thyrsis fully comprehends the herder's grief. Even Priapus, the most knowledgeable, knows only that Daphnis loves a girl, but not why he must flee from her. Only Aphrodite, Daphnis' final visitor and the only one to whom he offers any kind of response, knows what has put Daphnis into such a state. The fact that she alone possesses such knowledge suggests that she plays an active role in Daphnis' demise, as indeed does her mocking language in lines 95-8, as well as Daphnis' hostility towards Aphrodite and Love in lines 100-113. Even though Aphrodite and Eros are clearly responsible

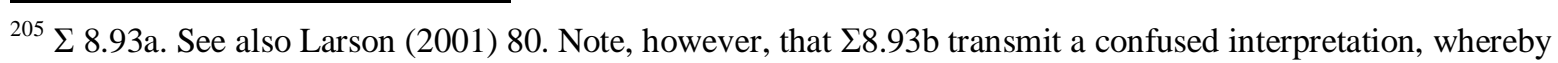
Xenea is herself the nymph, rather than the mortal beloved. This name itself turns out to be very important, and we will make more of it later. See below, page 80. 
for Daphnis' fate in some way, however, the specifics of that fate are mentioned only in the most allusive terms. Aphrodite sums up the entire narrative behind Daphnis' present predicament in these words (97-98):

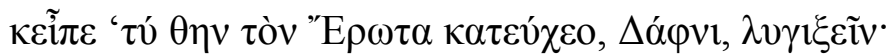

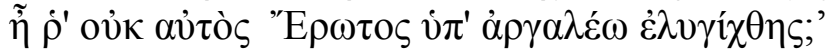

And she said 'Surely you once swore, Daphnis, that you could master Love. But now aren't you the one who has been mastered by grievous Love?

Thus we know that Daphnis "boasted" or, more likely, "swore" or "bound himself in an oath" that he could "bind" love, a term from wrestling that suggests Daphnis thought he could be victorious over love. ${ }^{206}$ We also know that Daphnis has not been successful in keeping this oath, since it turns out that he has not defeated Love, but has been defeated by it. Daphnis' defeat is also confirmed by his statement in line 103 that he will be a spite to Love even in Hades, as well as his claim in 130 that he is being drawn into Hades at the hands of Love. This much Thyrsis tells us. But the Idyll leaves us in the dark as to the circumstances of Daphnis' oath as well as the circumstances of his failure to live up to that oath. The remainder of Thyrsis' song offers no further hints as to the narrative that led Daphnis to such a state of despair.

Even though Idyll 1 merely alludes to the story of Daphnis' oath, the narrative is once again helpful in filling the gaps. In all three of our major sources on Daphnis, Parthenius/Timaeus, Diodorus and Aelian, ${ }^{207}$ the nymph who is in love with Daphnis places an injunction upon him: he is not to sleep with another woman, or else he will come to harm. It is this injunction to which Aphrodite's words in 97-98 must refer. ${ }^{208}$ Daphnis is bound by an injunction not to love another woman, but he has not resisted. In the non-Theocritean sources, Daphnis comes to harm following his broken promise. In Parthenius/Timaeus, Diodorus and

\footnotetext{
${ }^{206}$ On these terms, see Hunter (1999) 95.

${ }^{207}$ Diodorus (4.84), Timaeus in Parthenius (Narr. Ama. 29), Aelian (VH 10.8).

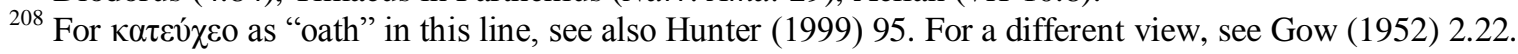


Aelian, the nymph blinds him in vengeance for loving another woman. Other evidence, however, suggests that narratives of the herder's death were already in circulation by the time Theocritus composed the first Idyll. $\Sigma 8.93$ preserves a tradition according to which Daphnis not only goes blind, but falls off a cliff. As early as Nymphodorus, the $3^{\text {rd }}$ century BC Sicilian historian, there are reports of a tomb of Daphnis, ${ }^{209}$ again suggesting the existence of alternate traditions in which Daphnis dies on account of his betrayal of the nymph.

Thyrsis' song may even begin with a sly allusion to the circumstances surrounding Daphnis' troubled romance with the nymph. In lines 66-69, the singer scolds the nymphs for being strangely absent at the time of Daphnis' destruction. Their absence is strange indeed, especially considering the nymphs' symbiotic relationship with features of the landscape they inhabit. ${ }^{210}$ It may be, however, that what lies behind the nymphs' extraordinary absence is their anger at Daphnis: they have departed because Daphnis has jilted one of their number.

This broken injunction is the narrative catalyst that has set Thyrsis' song in motion. Rhetorically, it comes at a point of climax in the poem. Up to the point of Aphrodite's visit, each of Daphnis' interlocutors has failed to solicit a response from the dying hero. Each of these interlocutors has, moreover, been bewildered by Daphnis' behavior; each approaches Daphnis with a question. Aphrodite, too, asks a question, but her question betrays an understanding of why Daphnis suffers (97-98). She is in a position of knowledge not shared by any of Daphnis' other visitors. It is perhaps for this reason—-because Aphrodite's knowledge of Daphnis' fate betrays her role in causing it — that Daphnis finally breaks his silence in response to the taunts of the goddess, whom he proceeds to hold directly responsible for his fate.

So what is the role of Aphrodite in the destruction of Daphnis? This is a difficult

${ }^{209} \Sigma$ 1.65-6b-c. Cf. Larson (2001) 80.

${ }^{210}$ Above, 22-23. 
question, because Aphrodite does not appear in any of the sources on Daphnis outside the Idylls, raising the possibility that the goddess' prominent role in Daphnis' downfall is an innovation of Theocritus himself. Even if Aphrodite's prominence is a new addition to the Daphnis narrative as told by Theocritus, however, it fits naturally into the plot as reported by other sources. Her presence in Thyrsis' song constitutes an extension of the storyline familiar from elsewhere. The exchange with the goddess dramatically foregrounds the oath that Daphnis has sworn to the nymph and failed to uphold. These lines have been deliberately highlighted by the poet: until now, Thyrsis' song has been composed almost entirely of questions. Only the pair of verses that Aphrodite speaks convey anything approaching a definite assertion, an explanation of why Daphnis suffers. And it is Aphrodite who possesses this knowledge. Since the only words that Aphrodite speaks in Idyll 1 are lines 97-98, the two lines that refer to Daphnis' oath, it follows that Aphrodite's role in the story of Daphnis is somehow connected to that oath. The most likely scenario, I suggest, is that Aphrodite is the cause of the love that compels Daphnis to break his oath to the nymph. Aphrodite's prominent role in Thyrsis' song and her focus on the oath would be appropriate in this case, since Daphnis' violation of his oath to the nymph is the act that sets the entire narrative of the song in motion: the algea Daphnidos cannot take place without it.

\section{FEATURES OF THYRSIS' SONG EXPLAINED BY NEAR EASTERN PROVENENCE}

Such a reconstruction of Aphrodite's role in Idyll 1 and its emphasis on the importance of the violation of an oath fits well with the discussion of parallels established in Chapter 1, which demonstrates that the story of Daphnis is in fact only a single example of a broader narrative pattern with roots in the Near East, in which a young male mortal or dying god is the beloved of a female divinity; the female places an injunction upon the male; following his violation of the 
injunction, the male comes to harm resulting from the jealousy or anger of the female. ${ }^{211}$ Although Theocritus has intentionally crafted Idyll 1 to be mysterious, the narrative pattern established in Chapter 1 along with the analysis of the Idyll conducted so far in this chapter allow us to understand what has driven Daphnis to death. The young herder was the beloved of a nymph, to whom he had sworn an oath to be faithful. He has broken this oath with a mortal princess (named Xenea, according to Idyll 7.73); the nymph therefore impels Daphnis to his death. In the version of the story upon which Theocritus bases the song of Thyrsis, Daphnis seems to have met a watery end, as indicated by line 140, which will be discussed later in more detail. Thus, at least in formal terms, we have answered the question of why Daphnis dies: Daphnis dies because he is related, in both historical and narrative terms, to a large group of figures that die after being the eromenoi of female divinities. More specifically, Daphnis dies because he has been the lover of a nymph, who became jealous of his relationship with another female and destroyed him for it. (In some versions of the story Daphnis is only blinded, while in others he dies as a result of the nymph's jealousy. The difference in endings is merely a variation on a larger theme; in both cases, the narrative pattern of the algea Daphnidos remains constant.)

But the fact that Daphnis belongs to this group of mythological figures related ultimately to Dumuzi also explains a number of other peculiar features of Idyll 1. I will now offer a brief catalogue of formal elements of the song of Thyrsis that are most likely attributable to the Near Eastern origins of the Daphnis narrative.

\section{The Pathetic Fallacy}

Thyrsis begins the algea Daphnidos by listing some important natural features of Sicily and calling on the nymphs, the divine embodiment of the island's landscape (66-69):

${ }^{211}$ See above, 29-46. 


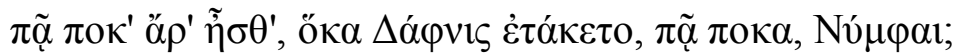

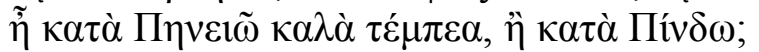

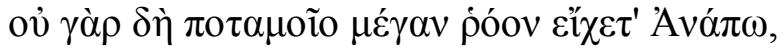

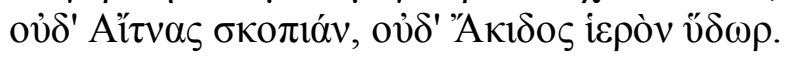

Where were you when Daphnis was pining, where were you, Nymphs? Were you in the lovely glades of Peneius or of Pindus? For you did not haunt the great stream of the river Anapus, nor the peak of Aetna, nor the holy water of the Acis.

That Thyrsis might have expected the Nymphs — so closely connected with the natural world of Sicily - to be present when Daphnis was mourned already suggests a close connction between the herder and the natural world, but this connection becomes even stronger in the following lines, when the flora and fauna of the island join in lamenting the herder's death. First the jackals, wolves and lions lament for Daphnis (71-72), followed by the cows of Sicily and their young (74-75). As he is on the verge of death, Daphnis bids farewell to the wolves, jackals and bears of the island, speaks of his connection to Sicily's woods, thickets and groves, and again bids farewell to the spring of Aretheusa in Syracuse and the nearby waters of the Thybris (115118). Upon his death, the natural world will be in turmoil, as Daphnis proclaims in a brief catalog of the adunata that will follow his demise (132-136):

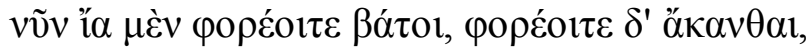

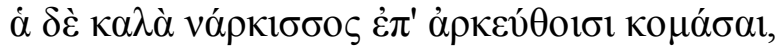

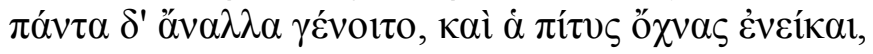

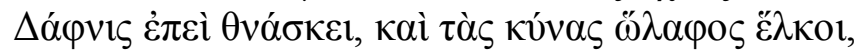

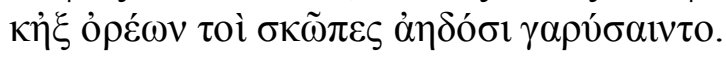

Now let the brambles bear violets, let the thorns bear violets, let the lovely narcissus grow long on the juniper, let each thing become another; let the pine bear pears, since Daphnis dies, and let the hart rend the hound; let the owls from the mountains sing against the nightingales.

Jasper Griffin has already traced the origins of the pathetic fallacy in Greek pastoral back to the Near East. ${ }^{212}$ Griffin's interests lie, however, in the literary bridges between Theocritus and Near Eastern predecessors, with an eye especially to the Iliad, and while I would certainly never

${ }^{212}$ Griffin (1992) 189-211, esp. 204-209. 
dispute the possibility that Theocritus may have been familiar with the pathetic fallacy from literature, it is more likely that cult was the primary mode of transmission, especially in light of the historical theory outlined in Chapter 1. Idyll 1 is in large part about Daphnis, a local Sicilian figure drawn from local Sicilian cult. Since the pathetic fallacy is closely associated with figures related to Daphnis, its use in Idyll 1 evokes the mythological and cultic context from which the Sicilian herder emerged.

The Sumerian composition "In the Steppe of the Early Grass," which depicts the search for and mourning for Dumuzi following his death, was based upon actual ritual laments for Dumuzi. ${ }^{213}$ In that poem, the sympathetic mourning of nature plays a central role in Inanna's lamentation for her consort:

Shepherd, lord Dumuzi, spouse of Inanna!

Lord of Arali! Lord of Dushuba!

My tamarisk which will never drink water in its garden bed!

Whose top formed no foliage in the steppe!

My poplar which will never empty its channel (of water)!

My poplar torn out by the roots!

My vine which will never drink water in its garden bed! $!^{214}$

In another Sumerian poem called "Dumuzi's Dream," in which the hero recounts a foreboding dream of his own death to his sister Geshtinanna, Dumuzi's death is once again depicted by its effects on the natural world.

Woe filled his heart and he went out into the desertthe lad, woe filled his heart, and he went out into the desertDumuzi, woe filled his heart, and he went out into the desert, rested the staff on his shoulder, walked along wailing!

Forthwith set up a wail!

\footnotetext{
213 Jacobsen (1987) 56.

${ }^{214}$ Cohen (1988) 691. Cf. Jacobsen (1987) 61; Griffin (1992) 207.
} 
Forthwith set up a wail!

O desert, forthwith set up a wail!

O Marsh, forthwith cry out!

O crayfish of the river,

forthwith set up the keg of beer and a wail!

$\mathrm{O}$ frogs of the river,

forthwith cry out!... ${ }^{215}$

He describes the dream to his sister as follows:

Rushes rose for me rushes grew up for me, and a lone reed was shaking the head in grief [for me]...

In the forest a tall tree was uprooted for me all by itself. ${ }^{216}$

The close connection between Dumuzi and the natural world in death appears to correspond to his close connection to nature and fertility in general. Although Dumuzi was originally a god of shepherding, he became a god of vegetation on account of his syncretism with Damu, who was a vegetation god. ${ }^{217}$ Like his descendant Adonis, ${ }^{218}$ one distinguishing characteristic of Dumuzi is his bi-location, that is, his division of his time between the upper and lower worlds. In the "Inanna's Descent," when the goddess is charged with finding a substitute to replace her in the underworld, it is Dumuzi whom she chooses, in a fit of rage. But he does not spend the entirety of his year below; part of it is spent above ground. The periods of Dumuzi's bi-location correspond to the dry and fertile seasons of the year. Dumuzi would descend around July, at the end of his eponymous month, and rise again towards the end of the winter. ${ }^{219}$ At the end of the month named for Dumuzi, there were several days of rites, during which the god was

\footnotetext{
215 Jacobsen (1987) 28-29, lines 1-8.

216 Jacobsen (1987) 30, lines 27-28, 30.

${ }^{217}$ Mettinger (2001) 185, 203-204.

${ }^{218}$ Mettinger (2001) 210.

${ }^{219}$ Mettinger (2001) 203-204.
} 
mourned. ${ }^{220}$ Mettinger describes the climax of Dumuzi's rites as follows:

These rites culminate in Dumuzi's death, and his death is closely linked up with the demise of plant life. Thus in SAA 3: no. 38 we read that, "[h]is [de]ath is when they burn the roasted barley, which they were casting on Tammuz [Dumuzi], on the stones", and then the text goes on to describe Dumuzi as the very embodiment of vegetation: "Tamarisk is his topknot. Cypress is [his] trunk. [C]annabis is his bristle. Juniper is [his] thighs. Cedar is his knees..."221

Dumuzi's death, then, appears to have been symbolic of the annual vegetative cycle. The god would spend part of his time in the underworld, and part of it above.

A connection between a male dying and rising god and the annual vegetative cycle is also evident in subsequent deities and mythological figures whom Dumuzi has influenced, including Daphnis. Mettinger has argued that the traditions surrounding Dumuzi shape the stories of Ugaritic Baal, Adonis and Melqart. ${ }^{222}$ All of these deities were closely connected to the vegetative cycle, as is attested by their ritual and mythological backgrounds. ${ }^{223}$ Very importantly, these descendants of Dumuzi are also part of the tradition that, as Carter has argued, makes its way to Sparta to become the cult of Ortheia. ${ }^{224}$ The importance of the pathetic fallacy to Idyll 1 and Daphnis, therefore, matches the profile of a deity or hero who is ultimately descended from Near Eastern dying and rising gods, the line of descent posited in Chapter 1.

\footnotetext{
${ }^{220}$ Mettinger (2001) 193.

${ }^{221}$ Mettinger (2001) 194, citing SAA 3: no. 38: rev. 6-17 (Livingstone, Court Poetry, 1989: 98).

${ }^{222}$ Mettinger (2001) 209-212, 213-214.

${ }^{223}$ Mettinger (2001) 219-220. See also Mark S. Smith (2001) 104-120, who does not agree with the characterization of such figures as dying and rising (though he does characterize them as dying or disappearing [120]), that scholar nonetheless highlights a shared connection to funerary cult and natural fecundity.

${ }^{224}$ Carter (1987) passim, but esp. 383. The degree of Ugaritic Baal's influence on the Iron Age figures of Melqart and Adonis remains an open question; see Mettinger (2001) 72-76. Ugaritic Baal does appear, however, to have influenced the numerous local deities addressed by the name of Baal in the Iron Age. See, for example Lipinski (1995) 49-50, who is also more certain than Mettinger in postulating a continuity between Ugaritic Baal and Adonis and Melqart. Markoe (2000) 116 sees Iron Age Phoenician links back to Bronze Age deities such as Ugaritic Baal, but not without substantial autonomous religious development. See also the excellent article by Herbert Niehr in Brill's New Pauly s.v. "Baal."
} 


\section{Hostility between Daphnis and Aphrodite}

I have already mentioned the hostility between Daphnis and Aphrodite in Idyll $1 .{ }^{225}$ In lines 97-98, Aphrodite accosts Daphnis and appears to mock him for breaking his oath to the nymph who adores him. Daphnis retorts in an equally antagonistic manner: by pointing out that he is not the only one to have suffered the effects of love; the goddess herself succumbed to her passion for Anchises and Adonis, both of whom then suffered on account of her affection (1.105110). I have explained this hostility in the context of the reconstructed version of the Daphnis narrative. Aphrodite's presence in the poem indicates her role in driving the events that caused the algea Daphnidos. Daphnis' oath to remain faithful to a nymph vexes the goddess, who then causes the love affair that forces the herder to break his injunction.

The hostility between Aphrodite and Daphnis fits well with the pattern discussed above, in which erotic contact between a female divinity and a mortal male or dying god causes his destruction. In many of these cases, as in the stories of Dumuzi, Anchises and Adonis, it is the jealousy and anger of the female that causes the death or maiming of the male. Halperin has discussed a number of other cases of animosity between paredroi and the goddesses they accompany in Near Eastern myth. ${ }^{226}$

The matter becomes slightly more complicated when it is noted that, in the interpretation of the narrative put forth here, Aphrodite and Daphnis are not to be considered lovers - whereas, in most of the other parallels, the animosity between male and female arises from erotic jealousy. I suggest that the hostility between Daphnis and Aphrodite in Idyll 1 is a feature of the narrative preserved from a time prior to Ortheia's syncretism with Artemis. A narrative about Ortheia's hostility to her consort may well have been part of that goddess' tradition. But problems arise

\footnotetext{
${ }^{225}$ Above, 76-77.

${ }^{226}$ Halperin (1983a) 190-192.
} 
once she syncretizes with Artemis. Since Artemis cannot take a lover, the goddess' jealousy towards her paredros would no longer make any sense. Thus, there would be no cause for a hostile exchange of the type we see in Idyll 1 between Daphnis and Aphrodite. The tradition nonetheless preserved that hostile exchange as a feature of the Daphnis narrative, only now the hostility is shifted to a different goddess: the hostility that would have existed between the paredros and his female consort now shifts to the paredros and a goddess who is associated with his erotic behavior, but not the object of it, namely, Aphrodite. ${ }^{227}$

\section{Subsequent Regret for Hostility to Daphnis}

Despite the hostility between Daphnis and Aphrodite in Idyll 1, an odd feature of Thyrsis'

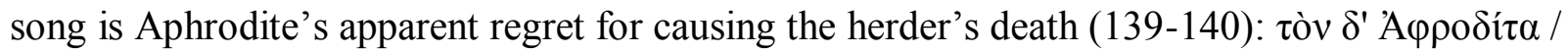

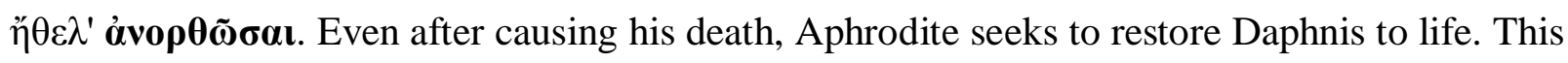
inconsistency of character in the female that causes the death of the paredros finds a parallel in the story of Dumuzi. As Bendt Alster has noted, "Inanna was by definition a highly ambiguous personality." ${ }^{228}$ In the Sumerian poem "Inanna's Descent," the goddess condemns her consort to death in a fit of anger and jealousy, yet almost immediately begins to repent, and herself devises a partial solution, whereby Dumuzi is to spend only part of the year in the netherworld. ${ }^{229}$ The language of Idyll 1.139-140, with its emphasis on Aphrodite's desire to resurrect Daphnis, echoes such a scenario. $^{230}$

As in the case of Aphrodite's hostility for Daphnis, her repentance would earlier have

\footnotetext{
${ }^{227}$ Some scholars posit, however, that Theocritus intends Daphnis and Aphrodite as lovers in Idyll 1. See Anagnostou-Laoutides and Konstan (2008) 497-527.

228 Alster (1996) 16.

${ }^{229}$ Alster (1996) 13-16.

${ }^{230}$ Halperin (1983a) 191 has pointed out another useful Near Eastern parallel to this pattern of jealous rage followed by regret, in the Ugaritic story of the hero Aqhat and the goddess Anat, who corresponds in many respects to Inanna and Ishtar.
} 
been a trait of the goddess in love with Daphnis. Here that emotional state is transferred to Aphrodite the goddess that is the figurative cause of that love, but who is not herself his lover.

\section{The Search for the Dying Hero}

One of the only things we learn about Daphnis' predicament in Idyll 1 is that, for some reason, a young woman is pursuing him over the countryside (82-85). This search for the dying hero also finds a parallel in the story of Dumuzi. ${ }^{231}$ In "Inanna's Descent," when the goddess condemns her companion to the underworld, Dumuzi takes flight, fleeing over the steppe from the gala-demons sent to haul him down to the realm of the dead. But these demons are not the only ones in pursuit; Inanna is also searching for her lover, having repented of her anger. ${ }^{232}$ In another Sumerian composition about Dumuzi, "In the Steppe of the Early Grass," the shepherd's mother and sister pursue him as he proceeds to his death. ${ }^{233}$

The search for the dying hero or god is repeated in the case of Ugaritic Baal. Like Dumuzi, Baal descends to the underworld. The inclusion of this descensus motif in the Baal epic has been attributed by Mettinger to the influence of myths about Dumuzi. ${ }^{234}$ After he has died, Baal's sister, the goddess Anat, searches for him all over the countryside. When she finally comes to the place where Baal has fallen into the Netherworld, Anat engages in ritual mourning. ${ }^{235}$ Several of the details pertaining to Baal's descent have a strikingly pastoral tone. Before he dies and enters into the netherworld, for example, Baal mates with a heifer, who bears him a son. ${ }^{236}$ Following his death, moreover, Anat's mourning for Baal is compared to that of a heifer for her calf. "A day, two days pass and [Maid Anatu] interrogates him. Like the heart of a

\footnotetext{
${ }^{231}$ Cf. Anagnostou-Laoutides and Konstan (2008) 505-508, who also discuss the search for the beloved as a Near Eastern literary trope. See also Anagnostou-Laoutides (2005) 139-140.

${ }^{232}$ Alster (1996) 13-16, esp. 15.

233 Jacobsen (1987) 62-72.

${ }^{234}$ Mettinger (2001) 207-209.

${ }^{235}$ CTA 5.6.25-6.1.32. Translation by Pardee, in Hallo and Younger (2003) 268.

${ }^{236}$ CTA 5.17-24. Translation by Pardee, in Hallo and Younger (2003) 267.
} 


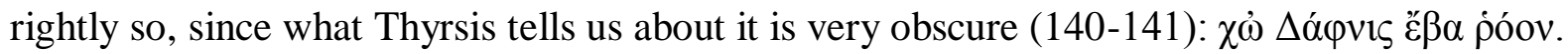

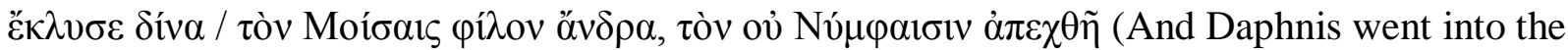
stream. The eddies washed over the man beloved by the Muses, whom the Nymphs had never detested). Scholars have proposed numerous different interpretations of Daphnis' death as it is found in the first $I d y l l,{ }^{241}$ but since the herder steps into a stream and is submerged in water, the most plausible explanation is that Daphnis dies by drowning. ${ }^{242}$ The ritual ramifications of death by drowning may provide us with a glimpse of Daphnis' role in popular Sicilian cult. This mode of death is yet another feature that links the Daphnis narrative back to Near Eastern parallels: the Sumerian poem "The Most Bitter Cry"243 recounts how seven demons pursue Dumuzi as he sleeps in his sheepfold. When they wake him, he escapes from the fold and flees towards a river. He attempts to swim from one bank of the river to the other, where he is awaited by his wife and mother, Inanna and Duttur. Dumuzi has misjudged the current, however, and Inanna and Duttur watch as he is swept down to the underworld. ${ }^{244}$

In addition, both Adonis and Osiris are connected with death by drowning, the former in cult and the latter in myth. ${ }^{245}$ The evidence for drowning in the cult of Adonis comes from Theocritus himself: at Idyll 15.133, the poet mentions a rite in which an effigy of the hero is placed in the sea, together with Adonis gardens. ${ }^{246}$ Although there are clear differences between Adonis and Osiris, Mettinger suggests that the common feature of drowning may have been

\footnotetext{
${ }^{241}$ See Hunter (1999) 67 for an overview of various theories.

242 Anagnostou-Laoutides (2005) 184-194 has emphasized the erotic valences of drowning, which she also brings to bear on the death of Daphnis. She also discusses the possibility of Near Eastern influence and drowning in the narratives of Dumuzi, Osiris and other figures.

243 Jacobsen (1976) 49-52.

${ }^{244}$ See Anderson (1993) 74 on the subject of Dumuzi's drowning in relation to the Daphnis story, as well as Halperin (1983a) 193 and Anagnostou-Laoutides and Konstan (2009) 501 with n. 18.

${ }^{245}$ Mettinger (2001) 178.

${ }^{246}$ Mettinger (2001) 178.
} 
enough to link the two figures in the minds of contemporary worshipers in Alexandria. ${ }^{247}$ There is good evidence of Dumuzi's influence on Adonis as he was celebrated in Egypt, and there are indications of Mesopotamian influence on the earlier, Levantine incarnation of Adonis at Byblos. ${ }^{248}$ The death of Daphnis by water, then, is yet another parallel to the tradition of the dying and rising god, with its roots in narratives about Dumuzi.

Theocritus is clearly aware of Daphnis' kinship with Adonis, since the poet makes reference to their similarity at Idyll 1.109-110. Besides their common subject matter of a dying hero/god, Idylls 1 and 15 echo each other in a number of ways, again indicating that Theocritus saw the two dying herders as similar figures, as I will discuss later in this chapter. ${ }^{249}$ It may be, therefore, that the narrative detail of Daphnis' watery fate had a corresponding reality in Sicilian cult - that Daphnis, like Adonis, was borne into the water at the conclusion of a cultic celebration.

\section{Mourning and Threnody}

A final commonality between Daphnis and the traditions surrounding dying and rising gods, beginning with Dumuzi, is the herder's connection with ritual mourning. As Mettinger affirms in his recent and comprehensive reappraisal of evidence surrounding the cult and myth of various dying and rising gods, such figures are frequently the object of mourning, including lamentation that employs the image of the pathetic fallacy and associates the life and death of the divinity with the fertility or infertility of the land. ${ }^{250}$ The lamentation of Daphnis' death in Idyll 1

\footnotetext{
${ }^{247}$ Mettinger (2001) 178-179.

248 Mettinger (2001) 209-211, 214.

${ }^{249}$ Below, 100-108.

${ }^{250}$ E.g. Mettinger (2001) 116-118, 122 (Adonis); 188, 193, 213 (Dumuzi); 62 with n. 34, 208 (Baal). See also Anagnostou-Laoutides and Konstan (2008) passim, but esp. 499, 501-502. On shared mourning rites of Dummzi, Tammuz, Adonis, Attis and Daphnis, see Halperin (1983a) 187-89, summarizing Berg (1974) 13, 17-20. Although Mark S. Smith (2001) 104-120 does not agree with the characterization of such figures as dying and rising (though
} 
is consistent with the evidence of ritual lamentation in connection with other dying and rising gods.

Thyrsis punctuates his song, “The Sorrows of Daphnis” ( $\tau \grave{\alpha} \Delta \alpha \dot{\varphi} \varphi v i \delta o \varsigma \alpha \alpha \lambda \gamma \varepsilon ’, 1.19,5.20)$,

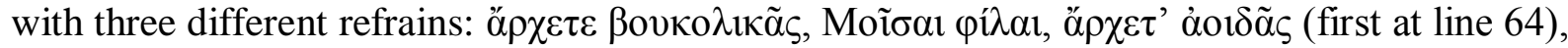

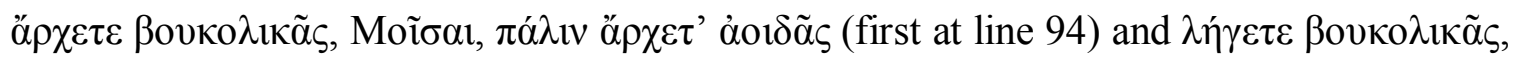

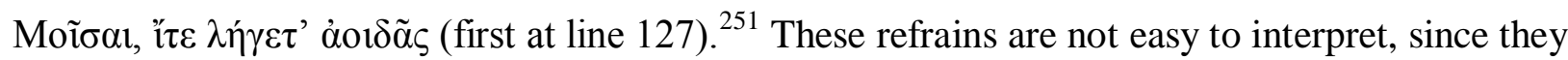
have a very complex effect on the reader, taking on various separate yet compatible meanings. As Hunter rightly notes (1999 86-87), the use of á $\rho \chi \varepsilon \tau \varepsilon$ is a typical form of invocation, familiar from other poets. ${ }^{252}$ In the context of the programmatic first $I d y l l$, however, as Hunter goes on to point out, the refrain is more than an invocation to begin a particular song; this invocation figuratively begins a new type of song, bucolic, and elevates that form to the realm of art for the first time. ${ }^{253}$

Beyond announcing the beginning and ending of Thyrsis' song and meta-poetically inaugurating the genre of Greek bucolic poetry, these refrains also announce the connection of Idyll 1 to ritual lament. In addition to being used in invocations, and in calls to begin or end a song, the verbs ö $\rho \chi \varepsilon \imath v$ and $\lambda \eta^{\prime} \gamma \varepsilon \imath v$ are regularly used of beginning and ending lamentation (LSJ).

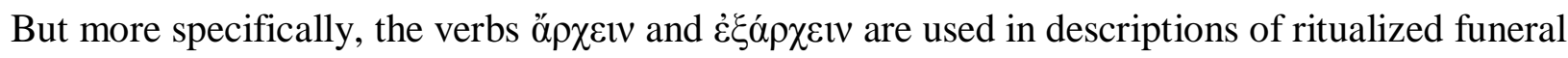
dirges as early as the Iliad. ${ }^{254}$ Homer uses the phrase $\tilde{\eta} \rho \chi \varepsilon$ yóoto of Andromache, who leads one

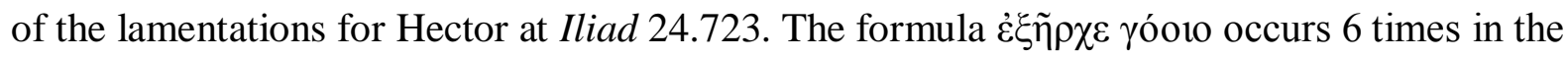
Iliad, twice in Book 18, when Thetis and Achilles lead dirges in the aftermath of Patroclus' death

he does characterize them as dying or disappearing [120]), that scholar nonetheless highlights a shared connection to funerary cult and natural fecundity. On the pathetic fallacy see above, pages 80-84.

${ }^{251}$ On the placement of the refrains and the consequences of placement for interpretation of the poem, see Gow (1952) ad 64-142 and Hunter (1999) ad 64-145, 127.

${ }^{252}$ Hunter (87) notes $P M G 14 \mathrm{a}, 27$ and 278.

${ }^{253}$ Hunter (1999) 87, 61.

${ }^{254}$ On the use of these verbs in Homer and in ritualized lamentation, see Calame (1997) 82-83 and Alexiou (2002) $131-132$. 
(18.51, 316), once at 22.430, when Hecuba leads the women of Troy in mourning for her son,

once at 23.17, when Achilles again leads the Greeks in mourning at the funeral of Patroclus, and twice in Book 24 (747, 761), when Hecuba and Helen lead the Trojan women in a lament over

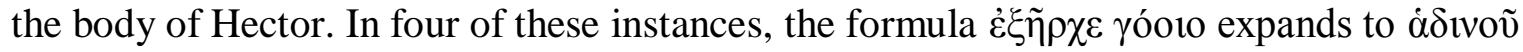

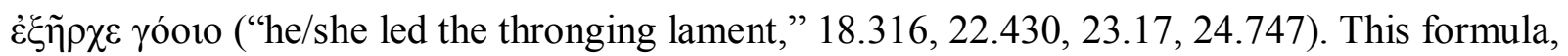
which distinguishes between an individual mourner and a group of mourners, illustrates the two distinct roles for the singers of laments: leaders and followers. Another detail from Book 24 confirms this division of labor: prior to the laments led by Andromache, Hecuba and Helen, the Trojans also bring in bards formally tasked with singing the lamentation, whom the poet labels

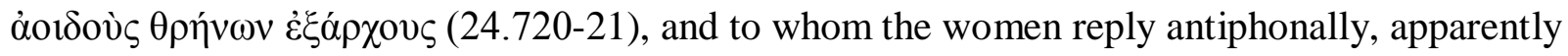

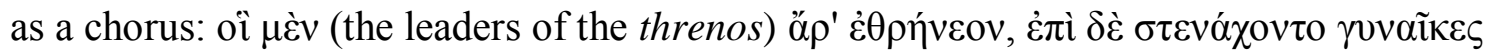
(24.722).

Citing the Hector's funeral dirges as evidence, Alexiou defines the structure of the lament in very precise terms:

The words used in Homer for beginning the dirge are $\dot{\varepsilon} \xi \alpha \dot{\alpha} \rho \chi \varepsilon ı v$ (to lead off) or á $\rho \chi \varepsilon i v$ (to begin). Their significance is most fully illustrated in the laments for Hector at the end of the Iliad, where each of the women leads off in turn, keeping her improvisation to a similar length and structure, and is followed by a refrain wailed by the whole company of women in unison. This gives the simple strophic pattern $A x A x A x$. Although discarded by the lyric poets in favour of the monadic and triadic forms, its traditional character is indicated by its survival in popular hymns, such as the Hymn of the Kouretes and the Elian Hymn to Dionysos. ${ }^{255}$

To summarize the evidence, then, the examples from the Iliad indicate that a vocabulary of

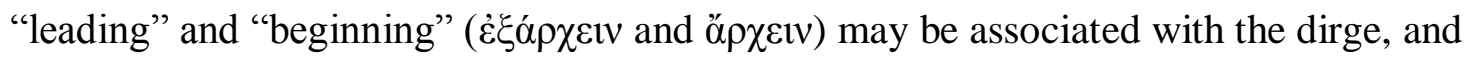

\footnotetext{
${ }^{255}$ Alexiou (2002) 131-132. Calame (1997) 82 has argued that the accompanying chorus is composed of women in the Homeric poems. While this claim is true of Hector's funeral laments, it does not extend to the laments led by Achilles, which make no mention of female accompaniment. At 18.316, Homer labels Achilles' fellow mourners simply as A 'xaıoí. At 23.17, it is clear that Achilles leads a specifically male group in the dirge, since the lamenters

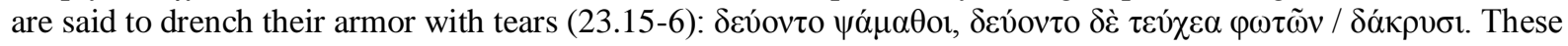
scenes of threnody led by Achilles appear to be exceptions to Calame's claim that the chorus of a threnos is composed of women.
} 
illustrates the division of the singers into leaders and a chorus of followers (perhaps usually but not always of women), which divides the song up into a simple strophic pattern.

Thyrsis' song in Idyll 1 evokes these structural and stylistic features of threnody, as is very appropriate to the context of mourning that pervades the whole song, which depicts Daphnis' death as well as his final lamentation for himself. First, there is the repetition, in two out of the three refrains, of $\alpha \rho \chi \chi \varepsilon \tau \varepsilon$, which is part of the technical language of the dirge. Second, the refrain breaks Thyrsis' song into "the simple strophic pattern $A x A x A x$," characteristic of threnody at its most basic level, as Alexiou argues. ${ }^{256}$ The song also alludes to the traditional antiphonal division of the dirge into leaders and followers. The refrain calls upon the Muses to "begin (ä $\rho \chi \varepsilon \tau \varepsilon)$ the bucolic song"; Thyrsis is calling upon the Muses to be leaders of the lament, or else to help him lead the lament. The alternation between refrain and stanza mimics the antiphonal structure of a lament. The content of this lamentation refers self-consciously, at times, to the very practice of lamentation which it enacts, as is especially clear from stanzas 2 and 3 :

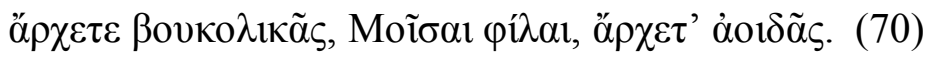

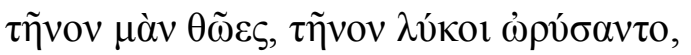

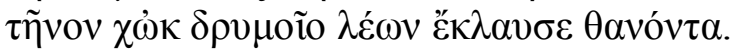

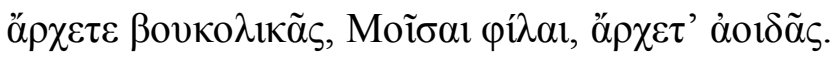

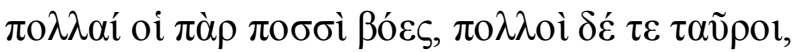

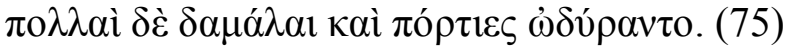

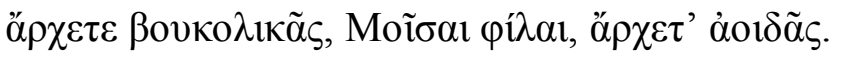

Begin, dear Muses, begin the bucolic song.

For him the jackals and the wolves howled, him the lion from the thicket bewailed when he died.

Begin, dear Muses, begin the bucolic song.

${ }^{256}$ Alexiou (2002) 132. Burris (2004) 168-169 also argues that refrains found in bucolic hexameter poets are intended to represent, if not actually reproduce, a strophic structure. 
Many were the cows about his feet, and many were the bulls, many calves and heifers were lamenting.

Begin, dear Muses, begin the bucolic song.

Both of these stanzas depict groups of animal mourners engaging in lamentation for Daphnis,

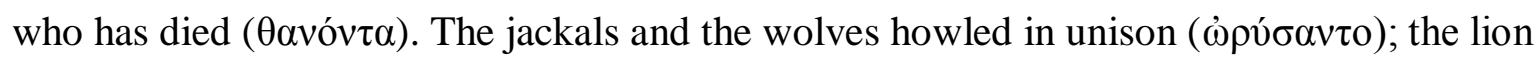

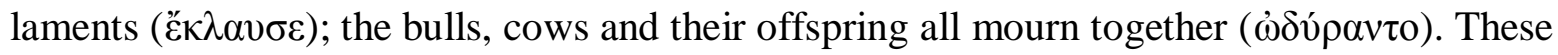
stanzas, although sung by the $\varkappa_{\xi} \xi \rho \chi 0 \varsigma$ of the dirge, nonetheless depict the followers of the dirge, who collectively groan in response to their leader. The depiction of the natural world in mourning for Daphnis, literally participating in a funeral lament for the dying herder, is consistent with what we find in the cases of dying and rising gods like Dumuzi, whose lament is filled with images of the pathetic fallacy. As with these earlier figures, Daphnis' death is linked to the health and fecundity of his native landscape: his death brings turmoil to the natural world of Sicily. The refrains of Idyll 1, which Theocritus probably drew from local Sicilian cultic rites, become a generic marker of bucolic, as indicated by Bion's Lament for Adonis as well as Moschus' Lament for Bion. ${ }^{257}$ The centrality of the refrain to the aesthetic and thematic aims of Idyll 1 likewise demonstrates how the importation of a Near Eastern rite into local Greek cult could have enormous influence on Greek literary style. Thus the refrains not only indicate the first Idyll's close connection to local Sicilian sub-literary tradition; they simultaneously hearken back to the Near Eastern origins of that tradition. ${ }^{258}$

\footnotetext{
${ }^{257}$ See also Burris (2004) 182.

${ }^{258}$ Burris (2004) 177 notes that refrains in literary authors may be used to mark the absorption of a sub-literary tradition into an elite work of literature. Burris cites the refrain in Theocritus, Idyll 2, as an example of this technique.
} 


\section{LOCAL CULT AND THE POETICS OF LOCALE}

The refrains that punctuate the song of Thyrsis are also an indication of the first Idyll's connection to popular cult and festival. There are a number of reasons that this is the case. First of all, in addition to mimicking the language of lamentation, the refrains may contain an allusion to festival song competitions. The three refrains of Thyrsis' song progress from "Begin," "Begin again" and "Cease," using the verbs ä $\rho \chi \varepsilon \tau \varepsilon$ and $\lambda \eta ́ \gamma \varepsilon \tau \varepsilon$. In addition to being threnodic and initiatory in tone, these refrains may well refer directly to the beginning and end of poetic competition, as two fragments from the collection of Carmina Popularia in PMG demonstrate. The fragments are identical, save for one key difference. The first is $P M G 863$, which is the seventeenth fragment of popular song, preserved by Julian the Apostate (Caes. 318D, I 409 Hertlein):

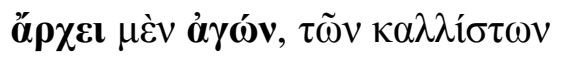

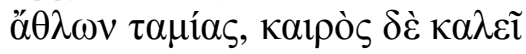

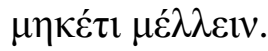

The competition begins, disburser of the most beautiful prizes, and the hour calls to delay no longer.

The second is $P M G 865$, the nineteenth fragment of popular song, preserved by Lucian in his Demonax (65):

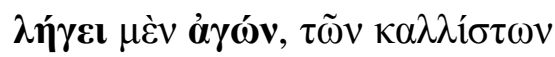

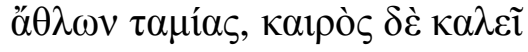

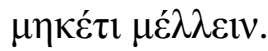

The competition ceases, disburser of the most beautiful prizes, and the hour calls to delay no longer.

The fragments are exactly the same, save for the change of the verb: both fragments begin or end an agōn. In the case of the fragment from Julian, the context makes it obvious that the contest is to be one of words, rather than athletic competition. Lucian explicitly states that the ditty is 
actually a tag used by the heralds during festival competitions, prefacing the fragment thus:

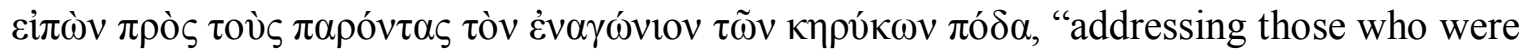
present with the passage that the heralds use at the games" (Lucian, Demonax 65). Given the festival context in which the ancient scholars claim bucolic originated, it is unlikely to be accidental that that the refrains which signal the beginning and end of Thyrsis' song echo the language to begin and end a competition.

The shared characteristics between Idyll 1 and Daphnis' Near Eastern forebears also suggest that Theocritus' poem draws on a context of actual cultic and festival celebrations of the Sicilian herder. We have seen that the festivals for the Near Eastern dying and rising gods to whom Daphnis is related involved ritual lamentation, a context which Idyll 1 evokes. ${ }^{259}$ Likewise, Daphnis' death by water may be connected to the ritual drowning of Adonis and Osiris in Hellenistic Egypt. ${ }^{260}$ A number of such figures, moreover, probably received cult on Sicily during Theocritus lifetime, as stated above: Adonis, Attis, Baal Hamon and Melqart. ${ }^{261}$ It is likely, therefore, that Daphnis was also the object of cult on Sicily, and we have already reviewed the non-Theocritean evidence for a Daphnis cult. ${ }^{262}$ It is reasonable, therefore, to situate Daphnis and the birth of literary Greek bucolic poetry in a ritual Sicilian context, a context we should expect on the basis of the scholia and the first chapter of this dissertation.

But there is still more contextual evidence to suggest that the song of Daphnis' death is not only an account of the fictional, mythical origins of the new genre of Greek bucolic poetry; the song of Thyrsis also offers an aetiological account of the genre's connection to local Sicilian rites devoted to Daphnis. A number of Theocritus' Idylls include aetiological accounts of cult-

\footnotetext{
${ }^{259}$ Above, 90-94.

260 Above, 89.

${ }^{261}$ Above, 44-46.

${ }^{262}$ Above, 19, 45.
} 
figures involving ritual mourning: Lityerses (Id. 10), Hylas (Id. 13) and Adonis (Id. 15). It appears, therefore, that the story of Daphnis in Idyll 1 should be understood not only in the context of Near Eastern forebears, but also in terms of Theocritus' apparent fascination with such figures in a Greek context. Theocritus' treatment of these three characters reveals a preoccupation with culture heroes associated with ritual dirge and thus reinforces a reading of Idyll 1 in terms of ritual lamentation. ${ }^{263}$ Moreover, there are valuable insights to be gained in noting the differences between the depiction of Daphnis in Idyll 1 and the deities mourned by dirges elsewhere in the Idylls, especially as regards the portrait of Adonis in Idyll 15.

The tenth Idyll depicts a singing contest between two reapers, Bucaeus and Milon. Bucaeus, so sick with love for a girl that he is unable even to mow a straight swathe, sings a love song. Milon, by comparison, is far less interested in girls and much more interested in work. As such, he sings a proper reaping song, which includes instructions about how to mow correctly

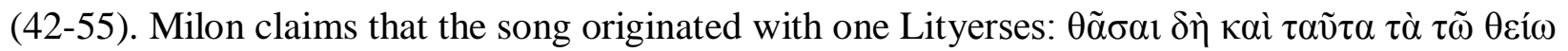

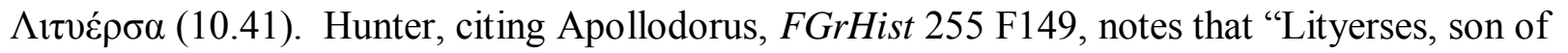
Midas, was a Phrygian culture-hero and inventor of agriculture after whom a reaping song was named. ${ }^{264} \mathrm{He}$ would challenge visitors to a reaping contest, with the punishment of death if they should reap too slowly. ${ }^{265}$ The story of this Phrygian inventor of agriculture overlaps strangely with that of the Sicilian hero of herding Daphnis. According to Theocritus' contemporary

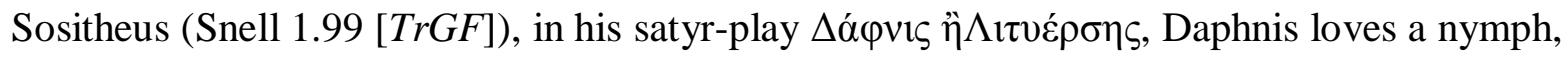
named either Thaleia or Pimplea, who is abducted by pirates. Daphnis eventually finds her working as a slave in Lityerses' Phrygian court. Heracles rescues both, and slays Lityerses. ${ }^{266}$

\footnotetext{
${ }^{263}$ On which see above, 90-94.

${ }^{264}$ Hunter (1999) 211. Cf. also Athenaeus 619a.

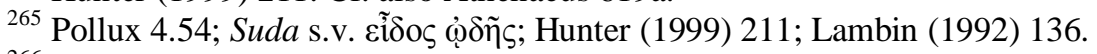

${ }^{266}$ Gow (1952) 2.1; Hunter (1999) 65, 212; Schol. Theoc. 10.41ce (Wendel).
} 
Despite the complex tradition reported here and the fact that Milon's song in Idyll 10 is not a dirge, Pollux 4.55 reports that the harvest songs to which Lityerses gave his name were threnodic. ${ }^{267}$ The mention of Lityerses in Idyll 10, then, utilizes a template that we also find in Idyll 1, albeit in a less emphatic way: both feature a rustic culture hero associated with the invention of a particular rustic labor; both heroes, too, are credited with the invention of a type of music associated with that labor. Moreover, both Lityerses and Daphnis were commemorated with dirges. $^{268}$

Idyll 13 relates a version of the story of Hylas. In Theocritus' telling of the story, Hylas accompanies his lover Heracles on the voyage of the Argo in search of the Golden Fleece. It is just the end of spring or the beginning of summer, when the Pleiades are visible in the sky once more. ${ }^{269}$ When Jason and the Argonauts arrive in the Propontis, in the land of the Cians, they make camp and prepare to fix a meal. Hylas goes off into the woods, in search of water for the meal of Heracles and Telamon. As Hylas dips his pitcher in a pool, the nymphs Eunica and Malis catch sight of the boy, fall in love with him and pull him down into the water, to remain with them forever. The rest of the Argonauts depart, but Heracles stays behind and frantically searches the woods, calling out for Hylas (13.58-60):

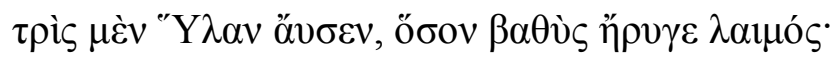

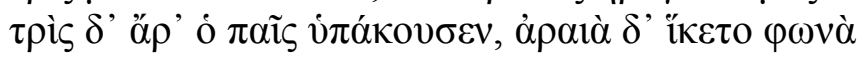

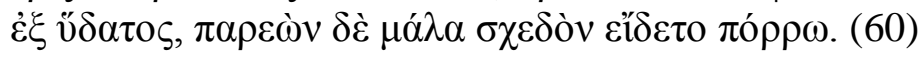

'Hylas' he shouted thrice with all the power of his deep throat, and thrice the boy replied, but faint came his answering cry from the water, and far off he seemed though very near at hand.

Heracles ranges far and wide in the wilderness, but never does recover his beloved Hylas.

\footnotetext{
${ }^{267}$ Cf. Lambin (1992) 136.

268 On Lityerses and threnody, see Pollux 4.55; Alexiou (2002) 58; Gow (1952) ad 10.41; Bremmer's article in Brill's New Pauly, s.v. "Lityerses."

269 13.25-8, with Hunter (1999) ad loc.
} 
The Heracles episode bears a striking resemblance to reports of cultic activity from various parts of Asia Minor, which include the singing of a dirge for Hylas or a figure very much like him. ${ }^{270}$ Strabo relates the story of Hylas' abduction by the nymphs, and goes on to note that the story was associated with a festival which continued to his own day (12.4.3):

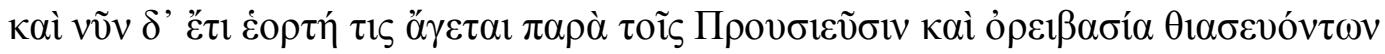

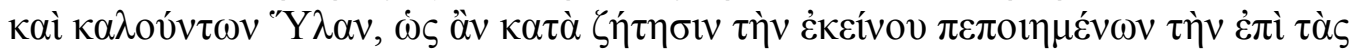

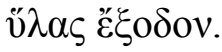

And still to this day a kind of festival is celebrated among the Prusians, a mountain ranging festival, in which they march in procession and call Hylas, as though making their exodus to the forests [vँ $\lambda \alpha \varsigma]$ in quest of him. (trans. Jones)

Idyll 13 is an aetiology of this ritual practice. ${ }^{271}$ In fact, 13.58-60 in which Heracles calls out the boy's name three times, may refer specifically to the practice of calling out in search of Hylas. ${ }^{272}$ Antoninus Liberalis reports (26.5) that a ritual call was part of the cult of Hylas until the second or third century AD: "to this day the inhabitants of the region sacrifice to Hylas beside the stream, and three times the priest calls him by name and three times Echo answers him." 273 These rites for Hylas, moreover, very much resemble those surrounding a boy named Mariandynus or Bormus. ${ }^{274}$ Athenaeus, who calls the boy Bormus, reports (620a):

they say that he was the son of an eminent rich man, and that in beauty and youthful flower he far surpassed all others; when superintending work in his own fields, he went to get water for the workers and disappeared. So the people of the countryside sought for him to the strains of a dirge with repeated invocation, which they all continue to use to this day. (trans. Hunter [1999] 263)

As Hunter notes, ${ }^{275}$ Athenaeus relies here upon Nymphis, a contemporary of Theocritus and local historian of the Pontic region, who also influenced Apollonius and Callimachus. As was the

\footnotetext{
${ }^{270}$ Hunter (1999) 262-3; Alexiou (2002) 59. Hunter discusses the mythographic sources about Hylas in detail.

${ }^{271}$ So Hunter (1999) 262-263.

272 So Hunter (1999) 263.

273 Translation Hunter (1999) 263.

274 On this topic in general, see Alexiou (2002) 58-59; Hunter (1999) 263.

${ }^{275}$ Hunter (1999) 263.
} 
case with Lityerses, the rites of Mariandynus, Bormus and Hylas "appear to have originated in some kind of vegetation cult, in which the reaping of the corn or the harvesting of the vine, fruit and flowers was lamented." ${ }^{, 276}$ As was the case in Idyll 10, where Theocritus invokes Lityerses, so Idyll 13 evokes the origins of a type of rustic song related to threnody, associated with a particular rural labor. This topic is clearly a major preoccupation for Theocritus: the template laid out in both Idylls 10 and 13 also appears in the lament for Daphnis of Idyll 1.

\section{Adonis vs. Daphnis: Pan-Hellenism vs. Poetics of Locale}

Idyll 15 again takes up the subject matter broached in the programmatic first $I d y l l$, an idealized male hero who dies and is memorialized by a dirge. This time the subject is Adonis. The similarity between Idylls 15 and 1, however, is more thoroughgoing than shared subject matter: Idyll 15 is the mirror image of $I d y l l 1$, but with a drastic change of setting. Instead of taking place in a bucolic locus amoenus, situated in the backcountry of a Doric island, the scene is now set in crowded, cosmopolitan Alexandria. Moreover, the partial subject matter of both Idylls is extremely similar, but also decisively and importantly different: Idyll 15 depicts a cult song for Adonis, Idyll 1 a cult song for Daphnis.

These thematic similarities already noted between Daphnis and Adonis ${ }^{277}$ are also paralleled by the structural similarities of Idylls 15 and 1. Idyll 1 is composed of an extended conversation between Thyrsis and the goatherd, in which the two characters become acquainted and discuss the terms of their artistic exchange; after this introductory portion of the poem comes the exchange, in which the goatherd crafts an ecphrasis of an elaborate cup, followed by Thyrsis' rendition of the "Sufferings of Daphnis." Idyll 15 begins with an extended conversation between Gorgo and Praxinoa, and their interactions with various secondary characters. When the women

\footnotetext{
276 Alexiou (2002) 59.

${ }^{277}$ Above, 34-38.
} 
finally arrive at the palace, both Gorgo and Praxinoa are startled by the beauty of the tapestries

they behold, and burst out in spontaneous ecphrases (78-86):

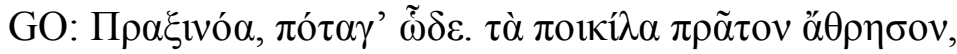

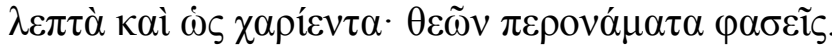

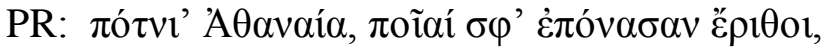

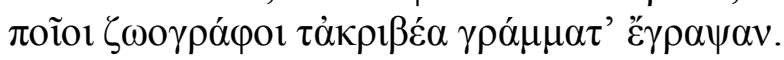

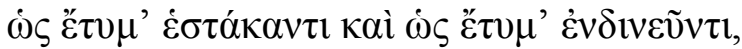

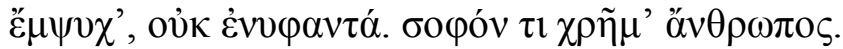

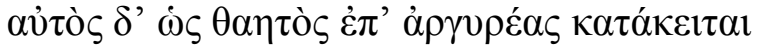

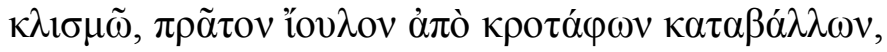

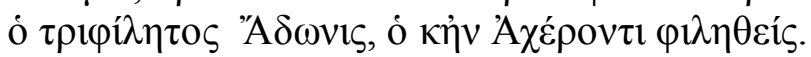

\section{GORGO:}

Praxinoa, come over here. First take a look at this embroidery; so fine and graceful. You'd say these tapestries were the garments of the gods!

\section{PRAXINOA:}

Oh queen Athena, what a labor, and for such spinsters! Such painters to plot their lines with so much precision! They stand there, like they're real; they waver there, like they're real, made of living souls, not wool. What a clever thing is man. And there's the boy himself, like a wonder, lying on his silver couch, the first down sprouting on his cheeks, thrice-loved Adonis, loved always, even in Acheron.

These lines are strongly reminiscent of the ecphrasis from Idyll 1 . Here in Idyll 15, the tapestries are $\theta \varepsilon \tilde{\omega} v \pi \varepsilon \rho o v \alpha ́ \mu \alpha \tau \alpha$, "garments of the gods" (79), while the depiction of a woman on the kissubion of Idyll 1 was $\tau \imath \theta \varepsilon \tilde{\omega} v \delta \alpha i \delta \alpha \lambda \mu \alpha$, "a work of art fit for the gods" (32). Moreover, both depictions emphasize the wonder created by viewing the work of art being described. In Idyll 15, the image of Adonis is marvelous: $\alpha \dot{\tau}$ ò $\varsigma \delta$ ' $\dot{\varsigma} \theta \alpha \eta \tau$ ò $\varsigma$ (84). In Idyll 1, the cup as a whole is marvelous, so marvelous that it will strike the viewer right to the heart: $\alpha i \pi \mathrm{i} \lambda \iota \kappa o ̀ v ~ \theta \alpha ́ \eta \mu \alpha \cdot \tau \varepsilon ́ p \alpha \varsigma$

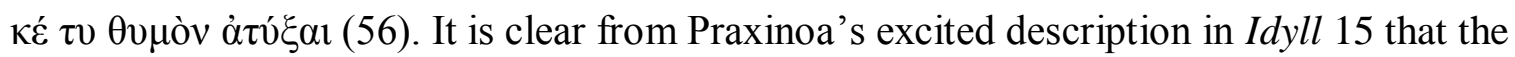
tapestry has affected her in just this way.

Following Praxinoa's ecphrasis (and her spat with an Alexandrian stranger who criticizes her rustic Doric drawl), the two women proceed to watch a female singer perform a hymn for 
Adonis. The narrative shape of Idyll 15, then, is very close to that of $I d y l l 1$. Both poems may be roughly divided into three sections: an initial conversation between the main characters, an ecphrasis, and a song dedicated to a dying divinity. The similarities between the two poems invite the reader to compare them. And it is by virtue of these similarities that the differences between the two dirges - decisive and important for the poetic program of Theocritus - come so strikingly to light.

The difference in setting between Idylls 15 and 1, which trades the bustling and urbane cosmopolis of Alexandria for the rustic Doric countryside, is reflected in the choice of deity memorialized by the songs in each poem. Adonis of Idyll 15 is a Pan-Hellenic, even international figure, not tied to any particular Greek locale. The hymn to Adonis acknowledges the wider range of the deity's cult, while at the same time highlighting the Ptolemaic court as the patron of the festival at which the performance takes place. The performance occurs in the royal palace (22-4), under the auspices of Queen Arsinoe $(24,111)$. The singer specifically attributes the display of finery in honor of Adonis to the queen (111, with a description of the luxurious goods afforded the deity, 112-127). By setting the performance of the hymn in the palace and crediting Arsinoe with its magnificence, Theocritus fixes the poem in place: Idyll 15 is about bourgeois city life, the bustling streets of the city, and the importance of the Ptolemaic court and Arsinoe to public life in Alexandria. This poem is in large part about how place relates to cultureAlexandria is as much a character in Idyll 15 as Sicily is in Idyll 1. Alexandria, however, as a cosmopolis, a world capital, partakes of the cultures of disparate locales. ${ }^{278}$ Theocritus plays on this diversity in his poem. When the Alexandrian stranger hears Praxinoa's Syracusan accent, he mocks it (87-8), and Praxinoa responds by standing up not only for the culture of Syracuse, but of Corinth, the Peloponnese and all of Doric Magna Graecia. She and the Alexandrian stranger

\footnotetext{
${ }^{278}$ See e.g. Selden (1998) 290.
} 
enact a culture war in microcosm, standing on the crowded streets of the most culturally diverse city of its age. The algea Daphnidos stand in stark contrast to this cosmopolitan vision. In Idyll 1 the Sicilian shepherd Thyrsis sings a cult song for the explicitly Sicilian figure of Daphnis, legendary first singer of Sicilian bucolic, a song which self-consciously links itself to the geography of Sicily, invoking particular local landmarks, and opposing these features of Sicilian myth and landscape to myth and landscape from elsewhere.

Just as the Sicilian origin of Thyrsis is appropriate to the subject matter of his song and the Doric setting in which it is staged, so singer, setting and subject all cohere in Idyll 15 . The female songstress seems herself to be an immigrant: she is the daughter of an Argive woman (97), although she had performed at the same Alexandrian festival in the previous year (98). Adonis' consort, Aphrodite, has dominion over places separated by a vast difference and associated with different cultures: Golgi, Idalium, Eryx (100). Golgi and Idalium are both on Cyprus, which was only recently in Greek hands, held by the Persians until the conquest of Alexander. The island may have been the entry point of Adonis into Greek culture, and it came under Ptolemaic control in 294. ${ }^{279}$ Eryx, which had strong Phoenician and Punic associations, is on the north-western shore of Sicily, and was a Phoenician outpost before it was Greek. Each city named in connection with Aphrodite, then, points to her association with the Near East. The vast space between Cyprus and Eryx, moreover, suggests the vast domain of Aphrodite. ${ }^{280}$ In Idyll 1, where the goddess is associated with no particular location upon her arrival, but is told by a contemptuous Daphnis to leave Sicily and go back to the Troad (105-113), Aphrodite's eastern associations are not a source of stature, but contempt. Back in Idyll 15, moreover, Adonis is buffeted by Syrian perfume (114), and couched upon coverlets from Miletus and Samos (126-7).

\footnotetext{
${ }^{279}$ Gow ad loc.

${ }^{280}$ Gow ad 15.100.
} 
Most important, of course, is the simple fact that Adonis was acknowledged to be of foreign origin and was celebrated all over the Greek world. While the Adonis hymn of Idyll 15 clearly has local significance by virtue of its association with the Ptolemaic court, the deity it celebrates is certainly not a local divinity, as was Daphnis in Idyll 1. Adonis is celebrated here in Alexandria and everywhere else; Daphnis is explicitly Sicilian.

The hymn to Adonis makes reference to the practice of memorializing the hero in a ritual dirge, like Idyll 13 about Hylas (13.58-60); although the song in Idyll 15 is not itself a rendition of that dirge, it makes reference to that type of practice. We do hear, for instance, that the daughter of the Argive woman, who sings the hymn to Adonis, was best at the dirge in the previous year (15.98, ió $\lambda \varepsilon \mu \mathrm{ov})$; but the dirge itself refers to the ritual mourning that will occur at the following dawn, not to the hymn in Idyll $15{ }^{281}$ The singer also distinguishes the hymn she performs from the ritual dirges that will occur later in the festival (132-5):

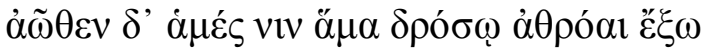

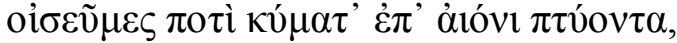

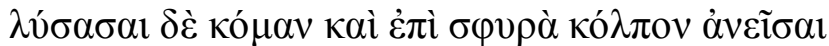

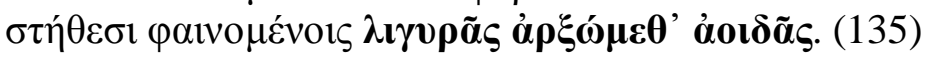

But at dawn, with the dew, we will bear him together to the waves that crash on the shore; having loosed our hair and letting our robes trail at our ankles to show our bare breasts, we will begin our clear-sounding song.

The phrasing of line 135 obviously invites comparison to the refrains of Idyll 1, drawing attention to the similarities and differences between the two songs. Like Idylls 1, 10 and 13, Idyll 15 ends with a song about a culture hero associated with rural activities, who dies and is subject to ritual lamentation. Idyll 15 is a very strong analogue of $I d y l l 1$ : they share the same narrative shape; Adonis and Daphnis, moreover, are genetically related and are alike in their most important traits. Likewise, Idylls 1 and 15 both end with ostensibly popular religious songs. Idyll

\footnotetext{
${ }^{281}$ See Gow ad 15.98.
} 
15 points to such a song in line 135 , but does not yet enact it. But Idyll 1 contains a stylized dirge, with its refrain, appropriately threnodic language, simple strophic structure and mimesis of antiphonal lamentation.

The similar subject matter of Idylls 1, 10,13 and 15 demonstrate Theocritus' preoccupation with doomed culture heroes and the ritual songs associated with them, but the comparison between Idylls 1 and 15 is especially instructive. Both depict cult songs for analogous figures, and they both seem to share a basis in cult.

The song of Adonis in Idyll 15 is performed in the context of a public festival, which included poetic competition. Thus, Gorgo remembers the performer of the hymn to Adonis as the

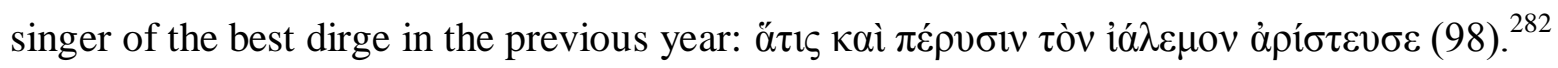
Theocritus alludes to a similar festival and competition context in Idyll 1. Various scholars have highlighted the "professional" tone of Thyrsis' performance of the "Sufferings of Daphnis.",283 Halperin points to the mention of Thyrsis' participation in a pastoral poetry competition $(24, \dot{\omega} \varsigma$

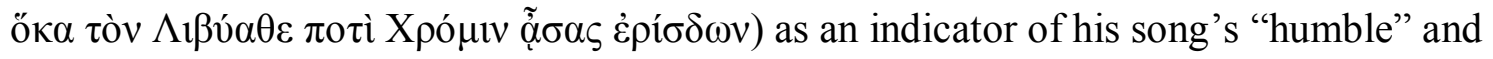
"simple" 284 origins, presumably in contrast to poetry from non-pastoral competitions. Hunter, in a similar vein, acknowledges that Thyrsis' performance is an analogue to the types of performances that Theocritus and Callimachus might have given at real competitions, but hesitates to connect the song of Thyrsis to an actual festival context:

[Line 1.24] presupposes (and thereby inaugurates) the existence of song 'contests', the rustic equivalent of the aristocratic games at which a Homer or a Hesiod competed and the dramatic contests of Athens. Thyrsis is most naturally understood to have sung 'the griefs of Daphnis' in this contest...In an amusing fantasy, Chromis may be imagined to have travelled from Libya to take part in one of these rustic 'matches', as Hesiod crossed the sea to Euboea (WD 650-7) and as Theocritus and his contemporaries travelled to poetic festivals; the most

\footnotetext{
${ }^{282}$ See Gow ad 15.98.

${ }^{283}$ E.g. Halperin (1983b) 163-164; Rosenmeyer (1969) 121.

${ }^{284}$ Halperin (1983b) 163.
} 
familiar institutions of classical poetry are thus to have their bucolic equivalents. ${ }^{285}$

There is no question that Theocritus exploits the notion of a pastoral poetry competition as a source of humor, especially in comparison to the grand poetry competitions of epic and tragedy, and that Idyll 1 inaugurates future literary depictions of pastoral song competitions. However, although Idyll 1 is certainly fictional, I wish here to emphasize its connection to actual religious cult, festival and song competitions. After all, our evidence strongly suggests that Daphnis received hero cult, and that the ancient theories about bucolic's origins in popular cults to Artemis may well be correct. ${ }^{286}$ The divine figures to whom Daphnis is most closely related were memorialized by yearly ritual lamentation, and Thyrsis' song is strikingly mimetic of threnody. Moreover, we have seen that Idyll 1 is in many ways the analogue of Idyll 15, a poem which very clearly depicts the popular Alexandrian cult of Adonis, one of the very figures subject to the yearly dirge and related to Daphnis. Given this context, it is likely that Idyll 1, like Idyll 15, also alludes to actual popular religious festivals.

In Chapter 1, I examined the numerous references in Thyrsis' song to local features of the Sicilian landscape. ${ }^{287}$ The thoroughgoing Sicilian character of Thyrsis song is germane to our attempt to understand the Daphnis narrative in its full historical context. The location of Daphnis within a wider context brings out the fact that he was a thoroughly local, Sicilian figure. It is easy to take for granted the insistence of Theocritus upon Sicily as a locale, Daphnis as a Sicilian, and Thyrsis as a Sicilian singer, both part of a vibrant oral tradition. It may seem unsurprising for a Sicilian to write poetry on Sicilian subjects. In light of the historical and cultural context of the Hellenistic age, however, it is not as simple as that. Poetry was becoming increasingly

\footnotetext{
${ }^{285}$ Hunter (1999) 75-76, Italics mine. See also Hunter (1999) 5-6.

${ }^{286}$ Chapter 1.

${ }^{287}$ Above, 22-24.
} 
international in the Hellenistic age and divorced from particular locations. ${ }^{288}$ The scholarship of Daniel Selden on Callimachus elaborates the extent to which Alexandria was a locus of displacement, itself like a multitude of different states or a "mosaic" of different cultures, a social phenomeneon which the poet replicates artistically: the theme of displacement characterizes his entire poetic oeuvre. ${ }^{289}$ In the light of increasing cosmopolitanism, together with the increased sense of displacement permeating Hellenistic poetry, Theocritus' insistent identification with Sicily, as well as his dramatization of its traditions in Idyll 1 serves as a selfconscious point of resistance to an increasing poetics of dislocation.

The choice of the Daphnis narrative as the centerpiece of Idyll 1, and therefore as the programmatic symbol for bucolic poetry as a whole, only accentuates Theocritus' dedication to establishing a poetics of locale that is consciously at odds with the poetics of dislocation more broadly at work in the Hellenistic period. As the survey of parallels to the Daphnis narratives demonstrates, there was a large group of figures with narratives similar to Daphnis from which Theocritus might have chosen his bucolic hero. A number of similar figures appear to have had a cultic presence on Sicily (Adonis, Attis, Baal Hamon, Melqart); beyond the island there were other characters with stories akin to Daphnis as well. But by choosing Daphnis as his focus, Theocritus links his new literary bucolic indelibly to Sicilian identity. The location of Daphnis at the center of bucolic ideology in the programmatic first $I d y l l$ is a signal to the reader of the consistently Doric, especially Sicilian, perspective that will play the chief unifying role in the new bucolic mode, a persistent feature of the new mode's choice of landscape, hero and language.

This chapter began by noting the remarkable mysteriousness of Thyrsis' song, a subject

\footnotetext{
${ }^{288}$ Hunter (2005a) 486.

289 Selden (1998) 295, 297-298 and passim.
} 
to which I return now, since the mystery of Daphnis' death is, I believe, central to the poetics of locale enacted by Idyll 1 . While the evidence in this chapter goes a long way towards establishing a context for the composition and performance of Thyrsis' song and demonstrates the degree to which Idyll 1 asserts itself as a distinctly Sicilian cultural product, the fact of its mysteriousness remains: we learn so little about the story of Daphnis in Idyll 1. Instead, the focus of Thyrsis' song is, to a much greater extent, on affect: the ballad dramatizes Daphnis' reaction to his narrative, but without focusing on the details of that narrative. Just as much as the song dramatizes the emotions of Daphnis himself, it also dramatizes the emotions of Sicily, of its plants, animals, inhabitants and rustic gods. The Song of Thyrsis dramatizes a ritualized version of communal grief that encompasses all features of the island, human, natural and numinous. I suggest that this emphasis on affect at the expense of narrative in Thyrsis' song is itself a feature of the poetics of locale embraced by Idyll 1 and is an artistic choice that divides the audience in two: an ingroup and an outgroup. The outgroup, most likely the majority of readers even in the age of Theocritus, is composed of those people left to wonder why Daphnis dies. The ingroup, on the other hand, do not need an explanation. These readers already know why Daphnis dies, because they already know the story or stories of his destruction. This ingroup is composed of Theocritus' fellow Sicilians. Less puzzled than the rest of us, they respond with knowing recognition to Theocritus' dramatization of a familiar ritual, his celebration of a familiar story from their local lore.

\section{THE ROLE OF ARTEMIS IN IDYLL 1}

Having performed this archaeology of the Daphnis narrative, it is now possible to understand the story in its full historical context. The question that naturally occurs in this light is, how are we to reconcile the theory of historical origins from Chapter 1 with the shape of the 
Daphnis narrative as we find it in Theocritus and the other sources? I have emphasized the importance of Artemis Ortheia in the transmission of the Near Eastern traditions that would eventually develop into the Sicilian narrative of Daphnis. Although Artemis is the focus of the scholiastic theories of bucolic's genesis, and although her importance to the tradition is preserved by Diodorus (4.84), her influence seems to be absent from the other ancient sources, as it appears to be absent from the Idylls themselves. If the goddess Ortheia, who syncretizes with Artemis, was so important to the development of Greek bucolic poetry, why would the goddess not appear more frequently in ancient theories about the development of the genre?

The survey of parallels to the Daphnis story makes one thing remarkably clear: in every case, the male paredros is the amatory object of the goddess with whom he consorts. The love of the female divinity for her paredros is an essential element of the story in each case, and is even cited on occasion as the specific cause of the male's destruction. Therefore, if Daphnis is related to the paredros of Ortheia in Sparta - a bond which entails a romantic relationship or the desire for such — and if Ortheia eventually syncretizes with Artemis, why is there not a similar romantic bond between Artemis and Daphnis?

Just voicing this question makes one thing obvious: a romantic relationship between Daphnis and Artemis would be absurd, completely contrary to the virginal nature of the goddess. However, the same cannot be said of Ortheia and her paredros. The goddesses from whom Ortheia originates had romantic unions with their male consorts. ${ }^{290}$ Indeed, the imagery at Ortheia's sanctuary points to her status as a fertility goddess and appears to depict a hieros gamos between her and her paredros. ${ }^{291}$ In Ortheia's cult, then, there is a sacred union between the goddess and her consort; but such a union between Artemis and Daphnis would be

\footnotetext{
${ }^{290}$ Above, 26-46.

${ }^{291}$ Carter (1987) 381-382. Cf. Carter (1986) 94-96.
} 
impossible to imagine.

So what are we to make of this contradiction? In fact, I suggest, this paradox is a natural outgrowth of the evolution of myths surrounding Ortheia in their new, Greek context. When Ortheia arrives at Sparta, she is accompanied by her consort, with whom she has romantic ties. But Ortheia, as we know, eventually syncretizes with Artemis. The romantic ties that had existed between Ortheia and her consort are no longer appropriate to Artemis Ortheia and her consort. ${ }^{292}$ Whereas Ortheia had been the romantic partner of Daphnis (or his close predecessor) upon her first arrival at Sparta, he now becomes the consort of a figure closely allied with Artemis instead, namely, the nymph with whom he falls in love, as is reported both in the ancient anecdotes and in the Idylls. ${ }^{293}$ Such a change would have come about with little difficulty: as we have discussed above, and as Larson has pointed out, there are many examples in the Greek folkloric tradition of stories in which a nymph falls in love with a man and places an injunction upon him, which is subsequently broken, to the man's peril.

In addition, Artemis and the nymphs appear frequently together in literature and myth. ${ }^{294}$ As early as Homer, Artemis is the depicted as if she were one of the nymphs, though far superior to them. Such is the portrait of Artemis in Book 6 of the Odyssey, where the goddess is the same as the nymphs in type, but best by far (102-108):

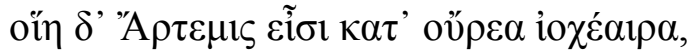

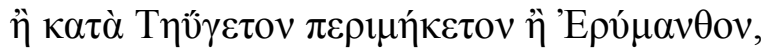

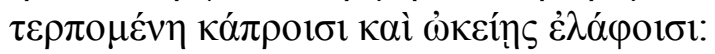

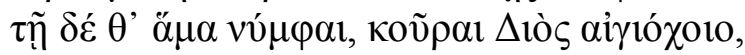

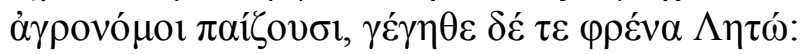

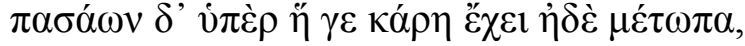

\footnotetext{
${ }^{292}$ For various views on the date of syncretization, see above, page 55, and, e.g., Larson (2007) 106, Carter (1987) 374-375.

${ }^{293}$ Sources describing Daphnis' affair with a nymph: Idyll 7.72-7; Parthenius 29 = Timaeus FGrHist 566 F83; Diod. 4.84; Aelian V.H. 10.18; $\Sigma$ (ad Theocritum) 8.93.

${ }^{294}$ Larson (2001) 107-110. Larson stresses the infrequency of Artemis' union with the nymphs outside of Homeric and Hellenistic poetry. She likewise highlights that evidence for joint worship of Artemis and the nymphs is scanty, save for some important exceptions, to be dealt with momentarily.
} 


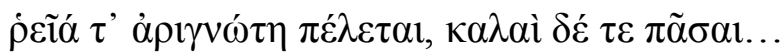

Thus does arrow-shooting Artemis go down from the mountain, either high Teygetus or Erymanthus, rejoicing in boars and in swift deer. And together with her sport the Nymphs who live in the wild, daughters of Aegis-bearing Zeus, and they warm the heart of Leto. But Artemis stands head and brows above the rest, and she's easy to pick out, though all of them are beautiful...

The Homeric Hymn to Aphrodite also mentions Artemis dancing with a band of nymphs and maidens (119-20). Likewise, Callimachus (Hymn to Artemis 13-17) makes Artemis demand sixty daughters of Oceanus as a choir, and twenty nymphs of Amnisius to watch over her boots and dogs. The association between Artemis and the nymphs may have been especially important in Syracuse, since both are connected to Ortygia. In the Trachiniae, Sophocles mentions Artemis of Ortygia and "her neighbors the nymphs" (211-14). After Artemis received the island of Ortygia, Diodorus reports (5.3.4-4.2), the nymphs created the spring Arethusa there as a favor to the goddess. While the evidence of joint worship dedicated to Artemis and the nymphs is fairly scanty, ${ }^{295}$ there are at least two examples, each of which is relevant to Sicily or to the pre-history of bucolic. The first is the cult of Artemis Caryatis: "Karyai was sacred to Artemis and the nymphs who served as her companions." 296 As it happens, one of the three scholiastic anecdotes about the origins of bucolic poetry concerns the cult of Artemis Caryatis. ${ }^{297}$ The story goes that the maidens who would have sung in worship of the goddess were hidden away during the Persian invasion; a group of rustics hymned the goddess in their place and bucolic was born. The second example comes from Elis, where there were festivals and myths attached to the goddess. It was in Elis that the river Alpheius was enamored of Artemis and conceived a desire to rape her as she was dancing with her nymphs. The goddess and her band outwitted the river, however, by disguising their faces with mud. When Alpheius could not distinguish Artemis from the nymphs,

\footnotetext{
${ }^{295}$ Larson (2001) 107-110.

${ }^{296}$ Larson (2007) 106; see also Larson (2001) 152.

${ }^{297}$ Wendel Scholia in Theocritum Vetera prolegomena Ba.
} 
he left. ${ }^{298}$ The river Alpheius, however, was said to dive under the ground, and resurface at the spring of Arethusa on Ortygia, in Syracuse; the cult of Artemis at Elis was transferred to Sicily along with the river. ${ }^{299}$

These connections between Artemis and the nymphs establish the context in which a nymph came to replace (Artemis) Ortheia as Daphnis' lover, most notably as they relate to Sicily and bucolic (although there is no reason that the change from Artemis to a nymph could not have taken place before Ortheia's arrival on Sicily). While Artemis and the nymphs are portrayed together most often in epic and Hellenistic sources, ${ }^{300}$ the two cults of the goddess from Elis and Laconia mentioned above-in which she is worshipped jointly with the nymphs — each have strong ties to bucolic or Sicily. Moreover, Sophocles and Diodorus provide strong evidence that Artemis and the nymphs were considered in tandem at Ortygia in Sicily. When Ortheia was syncretizing with Artemis, it would no longer have made sense for the goddess to take a lover. Who better to acquire Ortheia's old consort than a nymph? ${ }^{301}$

Artemis thus continues to exert her influence not only on ancient stories about Daphnis, but on the Idylls as well: the love between Daphnis and the nymph (Artemis' proxy), and Daphnis' broken promise to the nymph, are the major narrative forces in the first Idyll.

But what about Aphrodite? Much ink has been spilled in an effort to understand her role in the first Idyll as well. A careful reading of Idyll 1, however, reveals that Aphrodite is responsible for causing Daphnis to break his oath to the nymph and make love to the mortal princess. Thus, despite the obvious character differences between Daphnis and Hippolytus, Aphrodite's role is Idyll 1 is akin to her role in Euripides' Hippolytus: she destroys the life of a

\footnotetext{
${ }^{298}$ Larson (2001) 157-8; Strabo 8.3.12; Pausanias 6.22.8-11.

${ }^{299}$ Larson (2001) 213-14.

${ }^{300}$ Larson (2001) 107-10.

${ }^{301}$ Once a nymph replaces Ortheia as the love interest of Daphnis, his story fits nicely into the familiar pattern of men who take nymphs as lovers and suffer for it. See Larson (2001) 81.
} 
male associated with Artemis or her proxy, by inspiring a love that will lead to his destruction. Aphrodite does not figure in the story of Daphnis to begin with; nor is she the lover of Daphnis,

as some have suggested. ${ }^{302}$ Aphrodite's presence in Idyll 1, then, emphasizes Daphnis' inability to resist the power of love; it is perhaps modeled on Euripides' play and introduced for the first time by Theocritus himself. Even if Aphrodite does not appear in other accounts of the algea Daphnidos, her centrality to Idyll 1 highlights the importance of Daphnis' betrayal of the nymph to the story of his destruction.

\section{THE CONTEST OF THE CUP AND THE SONG: PANHELLENISM VS. POETICS OF LOCALE}

The conclusions reached here about the second half of Idyll 1 allow us to read the entirety of the poem in a new light. It been argued that the Song of Thyrsis constitutes a strong assertion of Sicilian local culture and identity. But Thryrsis does not sing in a cultural vacuum, and Theocritus does not write in isolation. Just as the shepherd sings his song at the behest of his companion in Idyll 1, Theocritus composes his poem in a complex cultural setting, in which hundreds of years of poetic tradition cannot go unacknowledged. The definition of a literary space amidst a crowed arena of predecessors is a necessary precursor to the establishment of the new Sicilian mode of bucolic poetry. Idyll 1 vividly depicts the creation of this space in the dramatization of artistic exchange between the two herders: it is a competition between a new local mode of poetry and the more canonical traditions symbolized by the goatherd's cup in the first half of the poem.

The Idylls are composed in dactylic hexameter, the meter of epic, and it is to epic that the bucolics in large part respond. ${ }^{303}$ Part of Theocritus' literary project is to re-apply the "high"

\footnotetext{
${ }^{302}$ Anagnostou-Laoutides and Konstan (2008) 497-527.

${ }^{303}$ In this paragraph I follow the reasoning of Fantuzzi and Hunter (2004) 139-141.
} 
meter of epic to more modest, "humanized" subjects. Theocritus creates a literary world of his own, which neither imitates reality as strictly as does mime, nor strays from reality as widely as comedy. Nor is the bucolic countryside very much akin to the epic world of heroes, gods and monsters; where the Cyclops does appear in the bucolics, he is strangely like a real Sicilian herder. Theocritus' choice of dactylic hexameter for the bucolics, so different from epic in diction, dialect and subject matter, simultaneously draws attention to the similarities and differences of these poems compared to epic. On the one hand, the bucolics are in the meter of "high epos," and thus declare their kinship to high literary works in that meter. On the other hand, the use of dactylic immediately highlights the gulf between epic and bucolic.

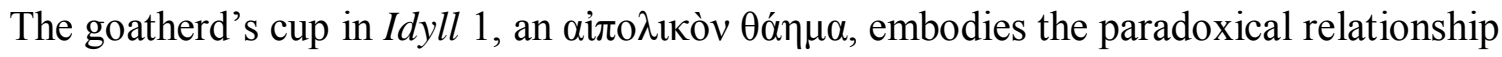
of bucolic poetry to epic. On the one hand, the cup is small and fine, marvelously wrought, and depicts reality with relative verisimilitude. The depiction of the woman on the cup is so wellcrafted that it would be worthy of the gods: $\theta \varepsilon \tilde{\omega} v \delta \alpha i ́ \delta \alpha \lambda \mu \alpha \tau \varepsilon \dot{\varepsilon} \tau v \kappa \tau \alpha \imath$ (32). Bucolic thus immediately aligns itself with the Alexandrian aesthetic ideal of small, finely-crafted poems, in opposition to monumental epic. The goatherd's cup may be small in comparison to Achilles' shield, but it is an exceptional piece of art nonetheless, and can hold its own when placed side to side with more traditional epos.

The description of the cup takes up contemporary artistic attitudes in other ways as well. The subjects depicted on the cup both imitate reality and seem drawn from fantasy, a posture that links the vessel to Alexandrian aesthetic trends. ${ }^{304}$ In the words of Hunter,

The description of the wooden cup evokes contemporary ceramics, metalwork, and statuary in a fantastic $\tau \dot{\varepsilon} \rho \alpha \varsigma$ (56), which is at once both 'realistic' and quite 'unrealistic'; like Thyrsis' song, the cup is a highly wrought and artistic version of an essentially humble and popular form. ${ }^{305}$

\footnotetext{
${ }^{304}$ Hunter (1999) 76-77. See also Fantuzzi and Hunter (2004) 141-167.

${ }^{305}$ Hunter (1999) 76.
} 
The goatherd's cup clearly demands to be compared to the Iliadic ecphrasis of Achilles' Shield and thus establishes a link between bucolic and epic. But this cup is tiny and modest in comparison with the grand majesty of Hephaistus' great shield, which depicts the entirety of the human world. Bucolic establishes a connection to the epic literary past, but also distances itself from it, staking a claim beside other Alexandrian, who share Theocritus' interest in short poems depicting scenes drawn from backgrounds unfamiliar from epic.

The treatment of epic themes in the programmatic first Idyll foreshadows Theocritus' juxtaposition of bucolic and epic elsewhere in the Idylls, which establish themselves as a more humble analogue to Homeric epic. ${ }^{306}$ Thus, the huge shield, crafted by a god for best of the Achaeans, is replaced in Idyll 1 by a small cup, given to the goatherd by a ferryman in return for a goat and a cheese. This is an example of Theocritus' "inversion" of epic motifs, whereby the grandiose language and themes of epic are refocused on characters and subjects from a more lowly background, mostly ignored in Homeric poetry. ${ }^{307}$ Such inversion is not unique to Idyll 1 , nor is Theocritus' preoccupation with defining his relationship to epic; these are persistent features of the bucolic Idylls in general. This obsession with the Homeric past, a powerful subtext in Idyll 1, rises to the surface and becomes explicit in Idyll 7, where Lycidas delivers an aesthetic manifesto in miniature (7.45-48):

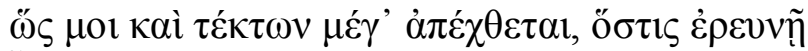

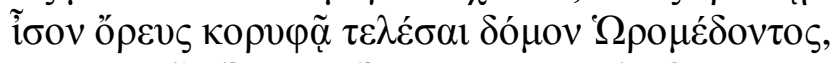

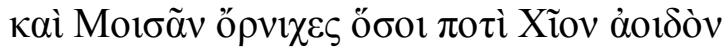

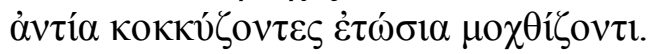

How greatly I detest the craftsman who aims to build a house high as the pieak of Oromedon, and all those fowl of the Muses who labor in vain, crowing against the Chian bard.

\footnotetext{
${ }^{306}$ For an excellent discussion of these matters, see Halperin (1983b) 217-248.

${ }^{307}$ Halperin (1983b) 217-248, esp. 237.
} 
Once again, this artistic manifesto is about Homer, but also has broader cultural implications. Theocritus here takes a side in contemporary aesthetic debate: "he declares himself an adherent to the aesthetic creed whose tenets are most familiar to us from the literary polemics of Callimachus [best articulated in fr. 1]."308

The ecphrasis of the cup in Idyll 1, then, in drawing attention to its similarities and differences from epic, highlights one of the major themes of the Idylls, namely, the exploration of their relationship to previous hexametric poetry. And by positioning the cup as a more humble version of Achilles' shield, Theocritus declares himself a partisan of Callimachus, on the side of small, finely wrought poetic vessels. Theocritus will constantly appeal to Homer, but his project is different.

Since this constant wrestling with the ghost of Homer will be especially important to our reading of Idyll 1, it will be helpful to spend a few more moments reviewing how the cup is an emblem of bucolic's relationship to epic. The very name of the vessel is laden with epic

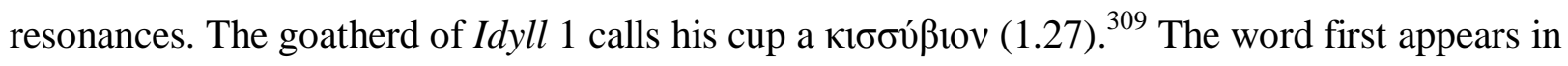
Book 9 of the Odyssey, where Odysseus entices the Cyclops to drink from such a vessel (9.345-

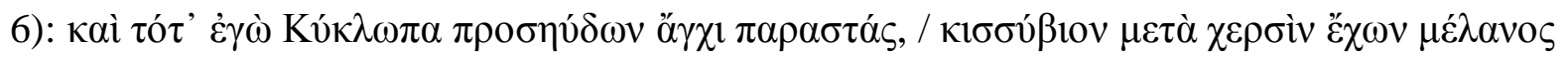
oivvoro (And then I addressed the Cyclops, standing close to him, holding a kissubion of dark wine in my hands). The Cyclops is a pastoral figure in the extreme, a primitive herder living in rustic isolation at the edges of the world, surrounded only by his herds, cheese and other

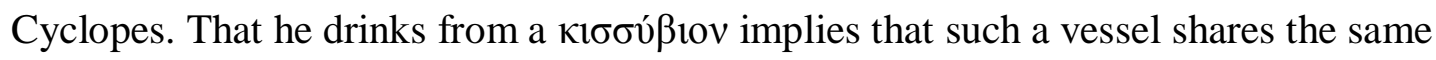

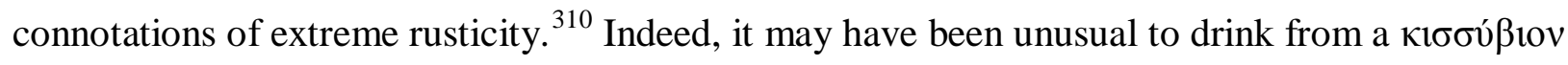
in the first place. The ancient commentators Dionysius of Samos and Ulpian both note that the

\footnotetext{
${ }^{308}$ Halperin (1983b) 244. See 244-247 on Theocritus' Alexandrianism.

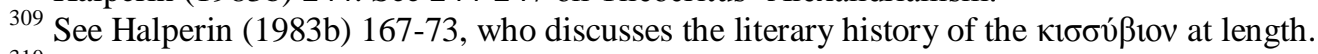

${ }^{310}$ Cf. Halperin (1983b) 168.
} 
Cyclops' vessel must have been very large. ${ }^{311}$ The word occurs elsewhere in the Odyssey, as well, but is only used as a mixing bowl, which suggests that the Cyclops' goblet was appropriately oversized. These other instances of the word appear in contexts that are similarly humble and rustic, though not to the extreme degree of Polyphemus' cave. Eumaeus, Odysseus'

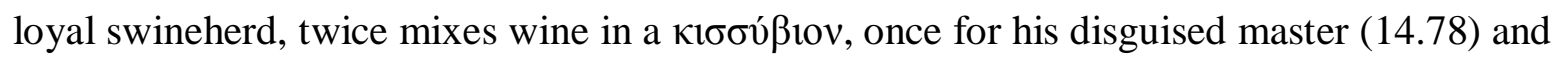

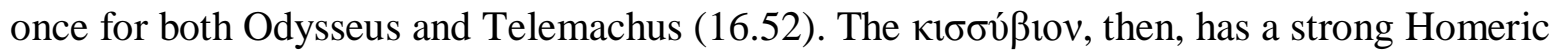
pedigree, where it is given rustic implications.

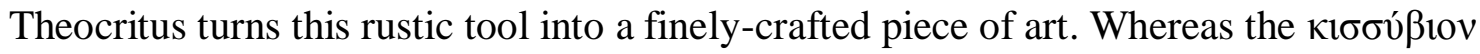
was the oversized and uncouth means of Polyphemus' drunkenness in Odyssey 9, Theocritus makes it small and delicate; it is as yet unused, still smelling of wax and the carving (1.27-9), and therefore unsullied by associations with the Cyclops' gluttony and intoxication. Callimachus echoes this deliberate reversal of Homer's precedent, along with the aesthetic implications of such a poetic act (178.7-12 Harder=178 Pfeiffer):

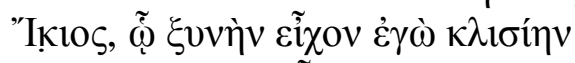

$\tilde{\eta} v \delta \grave{\varepsilon} \gamma \varepsilon v \varepsilon \dot{\varepsilon} \theta \lambda \eta v$

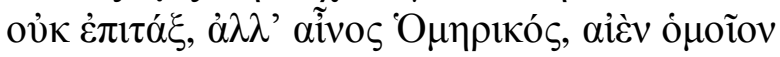

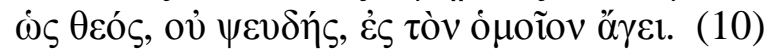

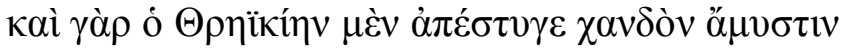

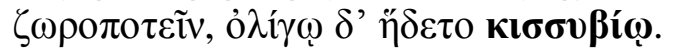

[B]y birth he was an Ician and I shared a couch with him, not by prior arrangement, but the word of Homer, that the god always brings like to like, is not untrue. For he too abhorred drinking neat wine with his mouth wide open in large Thracian draughts, but enjoyed a small cup. (trans. Harder, without linebreaks)

Just as in Idyll 1, Callimachus reverses the meaning of the rustic cup: he transforms the

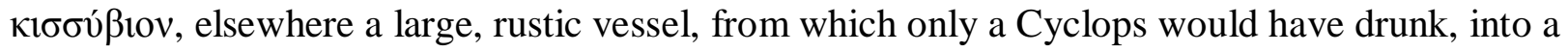
mark of good manners and delicacy. ${ }^{312}$

${ }^{311}$ Dionysius of Samos 481e; Ulpian 11.461d; cf. Halperin (1983b) 168.

${ }^{312}$ Cf. Halperin (1983b) 170. 
In addition to these broader allusions to the epic literary past- - to the ecphrasis of

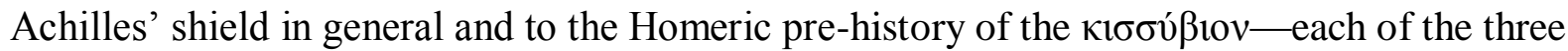
individual scenes on the cup has its own particular forebear in previous epic ecphrasis, as several scholars have pointed out. ${ }^{313}$ First comes the scene of the two lovesick men arguing over a woman, going back and forth in turn ( $\left.\dot{\alpha} \mu \circ \_\alpha \delta i \varsigma, 34\right)$ with quarrelsome words (1.33-35), which alludes to the scene of dispute on the Shield of Achilles, in which two men quarrel in turn ( $\dot{\alpha} \mu \circ \wedge \alpha \alpha \delta i \varsigma, 506)$ over a blood-price (18.497-508). The second scene on the cup is that of the old fisherman (39-42), which echoes a description from the Hesiodic Shield of Heracles, describing a fisherman, dolphins and fish. Finally, the third Theocritean scene, of the boy in the vineyard, combines elements from both the Homeric description of Achilles' shield (18.561-72) and the Hesiodic Shield (292-300). The description of the cup, then, symbolizes Theocritus' appropriation of epic meter for something new: a small-scale poetry, delicately wrought, about characters or situations that would not be at home in the world of Homeric heroes, gods and monsters.

In these ways, Theocritus self-consciously positions his bucolic poetry against the backdrop of epic. What we have seen so far mainly illustrates Theocritus' aesthetic engagement with Homer in line with the Alexandrian fondness for showing the grand traditions of epic in a humble or subversive light. But these aesthetic considerations go hand in hand with larger cultural concerns. The goatherd's cup in Idyll 1 is markedly different from Achilles' shield and yet uncannily like it. The refashioning of Achilles' shield to suit a rustic context illustrates bucolic's paradoxical relationship with epic: at once closely connected to it and at an artistic remove. This aesthetic statement is also a larger cultural claim. The Alexandrian era was a period of literal and cultural diaspora, but the response to this upheaval was a grand mission to identify,

${ }^{313}$ Hunter (1999) 76-77; Gutzwiller (1991) 90-94; Halperin (1983b) 176-189. 
categorize and study Greek literature, an effort best exemplified by the library at Alexandria. Homer was central to this process of codification. "Into this new city the poetry of Homer was of course imported, not only because of Homer's traditional place in education and society, but also as a self-conscious sign of identity, a talismanic assertion of continuity in a distinctly changed world." 314 Thus, Homer was not merely a literary forebear, to whom all subsequent authors had by necessity to respond (though he was very much that), but a source of continuity and identity to Greeks abroad and in a world undergoing transformation.

Homer had long been a source of Pan-Hellenic cultural unity. While the epic Kunstsprache is mainly Ionic, it does not resemble any epichoric dialect, admitting non-Ionic elements and being constructed so as to be understood everywhere in the Greek world. ${ }^{315}$ Just as the language is tailored to be broadly appealing, so are Homer's treatment of myth and religion. ${ }^{316}$ The Pan-Hellenic impulse of the Homeric tradition led to its adoption as a symbol of Greek cultural unity at an earlier point. Nagy has mined the Homeric Lives for evidence that his poetry was performed at Pan-Hellenic festivals as the common heritage of all Hellenes ${ }^{317}$ and has shown that Homeric poetry was an emblem of Ionic unity at festivals like the Delia and Panathenaia, as well as in the propaganda of the Delian League. ${ }^{318}$

The same phenomenon probably occurred in Sicily from the very beginning of colonization. As Greeks moved to Sicily and the West, as they left their mother-cities and began encountering foreign cultures, the Homeric epics were a means of maintaining their connection to central Greece, and asserting their own Greekness. ${ }^{319}$ The Cup in Idyll 1 lays claim to the

\footnotetext{
${ }^{314}$ Hunter (2004) 249.

${ }^{315}$ Horrocks (1997) 194; Rosen (1997) 463.

${ }^{316}$ Edmunds (1997) 436; Clay (1997) 499-500; Nagy (1979) 116.

${ }^{317}$ Nagy (2010) 51-55

${ }^{318}$ Nagy (2010) 10-28, 51, 329-30. On the Pan-Hellenicity of Homer, see also Graziosi (2002) 51-89, esp. 85-87, 245 and passim.

${ }^{319}$ Willi (2008) 6-7.
} 
"revered Pan-Hellenic possession" ${ }^{\text {320 }}$ of Homer, but also asserts the uniqueness of bucolic. While the goatherd of Idyll 1 obviously values his finely-wrought possession, and instills it with a glory ironically worthy of Achilles' shield, a character like him would be left in the background of the Odyssey. ${ }^{321}$ The language of epic is deliberately broad; the language of bucolic is also broad, in that it does not adhere to the rules of a single epichoric dialect. But it is markedly different from the Homeric Kunstsprache in being not only Doric, but a Doric with distinct local and popular coloration. ${ }^{322}$ Thus, the two types of poetry share a meter, but utilize drastically different literary languages. The settings of bucolic poetry, the scenes at the center of the genre, tend to be in places that are at the very edges of the epic imagination. Whereas the island of the Cyclopes was at the very ends of the earth for Homer, it is home for Theocritus. ${ }^{323}$ Despite these differences, however, the first half of Idyll 1, with its use of a new Kunstsprache and ecphrasis, is in large part about epic poetry: even as it sketches out the contrasts between epic and the new bucolic mode, it also lays claim to epic, by refashioning it.

The second half of Idyll 1, however, is much less concerned with noting the similarities between bucolic and epic. ${ }^{324}$ While the description of the cup demonstrated both the differences with and uncanny resemblance between the two types of poetry, the Song of Thyrsis strikes a far more independent note. Whereas the Homeric poems show a distinct lack of interest in local and hero cults, ${ }^{325}$ "The Sorrows of Daphnis" does just the opposite. The song is distinctly local, citing particular features of the Sicilian landscape and establishing a tension between Sicily and

\footnotetext{
${ }^{320}$ Horrocks (1997) 194.

321 See Halperin (1983b) 217-248, esp. 237.

${ }^{322}$ Chapter 4.

323 See below, 162.

${ }^{324}$ Pace scholars who have attempted to interpret Daphnis as a bucolic version of an epic hero. See Halperin (1983b) 220-221 for discussion and overview of this subject. See also Gutzwiller (1991) 100 and Larson (2001) 80.

${ }^{325}$ Edmunds (1997) 436; Clay (1997) 499-500; Nagy (1979) 116.
} 
elsewhere. ${ }^{326}$ Not only does Daphnis appear to have been an object of hero cult, ${ }^{327}$ the very type of subject that epic took pains to avoid, but Daphnis has his origins in local, popular cults to Artemis, as I have shown and as the ancient scholiasts report. ${ }^{328}$ The "Sorrows of Daphnis," therefore, draw a sharp divide between the epic and bucolic modes. Whereas Homeric poetry does its best to avoid religious figures of a distinctly local character, the song of Thyrsis does exactly the opposite. The first part of Idyll 1, while marking out the differences between the bucolic and Homeric modes, also lays claim to the Pan-Hellenic institution of epic. The song of Thyrsis, on the other hand, glorifies a peculiarly Sicilian religious institution, the local at the expense of the Pan-Hellenic.

\footnotetext{
${ }^{326}$ See above, 22.

${ }^{327}$ See above, 19, 45 .

${ }^{328}$ Chapter 1.
} 


\section{Chapter 3: \\ Great Books / Wive's Tales: Polyphemus, the Idylls and Local Identity}

\section{INTRODUCTION}

For a poet interested in exploring the boundaries between local and Pan-Hellenic, literary and folkloric, Polyphemus is the perfect subject. The story of the Cyclops is, on the one hand, an internationally attested oral-traditional narrative. But it is also part of the literary canon: Homer includes this folk story in the Odyssey, a founding text of Greek literature. Most scholars agree that the Odysseus and Polyphemus episode in Odyssey 9 draws upon a pre-existing, international, oral-traditional narrative: The Ogre Blinded. ${ }^{329}$ William Hansen's summary of the tale's most basic elements illustrates the connection between the traditional narrative and that found in Homer: ${ }^{330}$

Alone (or with a number of companions) a man comes to the dwelling of an ogre, usually a giant. The ogre keeps him (them) in his lair (and eats some of the men). In self-defense the hero, sometimes pretending to be able to cure the ogre's faulty eyesight, destroys the ogre's eyes (his only eye, his one good eye) by means of a spit (boiling liquid, etc).

Subsequently the hero covers himself (and his companions) with a sheepskin (sheepskins), joins the ogre's sheep, and crawls out of the lair (or they cling or tie themselves to live sheep).

Having escaped from the ogre's dwelling, the hero sometimes mocks the ogre, provoking him to retaliate in some fashion, such as by casting something harmful at the hero or by tossing to the hero a magic ring (or other magic object) that, when the hero puts it on his finger, repeatedly yells "Here I am," thereby guiding the blinded ogre to him; since the ring cannot be removed, the man is obliged to cut (bite) off his finger, after which he escapes, sometimes taking with him the ogre's sheep.

\footnotetext{
${ }^{329}$ Aarne-Thompson tale-type 1137.

${ }^{330}$ Hansen (2002) 289.
} 
Versions of this tale have arisen in widely disparate times and places; it is attested, for example, in the Icelandic sagas, medieval Turkish romance, a medieval French collection of prose tales, as well as The Arabian Nights. ${ }^{331}$

Although the tale is dispersed over a vast area in a vast number of languages, the majority of modern scholars have concluded that Homer is not the source. Rather, Homer draws on a previously existing narrative structure for his Cyclops episode, and so do most of the subsequent instances of The Ogre Blinded. While there is a common plot that runs through the various incarnations of the tale, there is enough dissimilarity, as well, to conclude that the tellers of later stories have not simply poached from Homer. Indeed, the influence of the Odyssey may only be detected in a small minority of cases. Hansen puts it best: ${ }^{332}$

In sum, the texts of this unusual story show sufficient similarity to one another to justify the conclusion that they are genetically related, but the younger texts cannot simply derive from the Odyssey by means of multiple instances of borrowing, for if they did, they would not show so much agreement as a group in features in which they disagree with the ancient Greek story. Nor, with their considerable geographical distribution and temporal spread, can they plausibly be explained by diffusion via any other literary work.

The most striking way, perhaps, in which Homer's tale differs from other versions of The Ogre Blinded is by the addition of the "Noman" motif," "in which a human being encounters a supernatural creature and, when asked, gives out his or her name falsely, usually as 'Myself,",334 with "Myself" replaced by "Nobody" (Outis) in Homeric narrative.

The fact that the Cyclopea familiar from the Odyssey is one of many examples of an oraltraditional tale-type does not diminish the cultural importance of Polyphemus, the specifically Homeric incarnation of the Cyclops who became most important in the Hellenic world. As

\footnotetext{
${ }^{331}$ Hansen (2002) 289, which has a recent description of the tale and related scholarship. Oscar Hackman collected 221 variants of the tale in his 1904 monograph, Die Polyphemsage in der Volksüberlieferung.

${ }^{332}$ Hansen (2002) 293.

${ }^{333}$ Thompson motif K602.

${ }^{334}$ Hansen (2002) 295.
} 
Malkin has noted, the Ogre Blinded folk-motif and the Homeric Polyphemus would have become indistinguishable to most Greeks at some point, due to the Pan-Hellenic importance of Homer. ${ }^{335}$ This view is surely correct, but, as Malkin himself goes on to point out, it is likely nonetheless that the Cyclopea retained a certain amount of the flexibility we would associate with an oral-narrative, even after the Homeric text became fixed and dominant in the cultural imagination. ${ }^{336}$ Some Classical archaeologists have contended that the early vase-paintings of the Cyclops, which differ in some of their details from the Odyssey narrative, may be folkloric rather than dependent on the Homeric story as we know it now. ${ }^{337}$

The resulting situation is one of extreme complexity, in which representations of the Cyclops in Hellenic culture could have had varying degrees of relationships to the Homeric paradigm: many artists and story-tellers must have consciously based their depictions very closely upon an explicitly Homeric model; some may have been aware of the Homeric tale, but freely differed from it in the details of their depictions; while a sub-stratum may well have existed of tales that were far more fluid, resembling Homer in the structure of the story, given their genetic relationship to it, but drawing on an oral-tradition more independent of the increasingly normative Homeric version. None of these hypothetical models is mutually exclusive of the other. The case of the Cyclopea is especially difficult, because it is well documented as a non-literary oral tale, but it also appears at an early date in a canonical work of Greek literature. Despite his Pan-Hellenic reputation, moreover, Polyphemus appears to have had

\footnotetext{
${ }^{335}$ Malkin (1998) 41.

${ }_{336}^{336}$ Malkin (1998) 42.

${ }^{337}$ Touchefeu-Meynier in LIMC VIII.1 1017-1018. See also Snodgrass (1998) x, 90-99, who summarizes his argument thus: "The scenes with the Blinding of Polyphemus... are a case in point: different, but roughly contemporary, artists display mutually exclusive combinations of apparent fidelity to the Odyssey account, and demonstrable adherence to a non-Homeric account. The likeliest inference is...that there is a plurality of versions on offer, of which Homer's, in much the form that we now have it, is one" (x). See also Lowenstam (2008) 13-15.
} 
a special importance to the Greek West, especially Sicily. ${ }^{338}$ The possibility that a local version of the Cyclopea as an oral-traditional tale may have been one source for variations in the literary tradition will be addressed at a later point, in the section on Galatea.

To understand the full nature of Theocritus' appropriation of the Cyclops into his bucolic world, we will need to weave all of these strands together. It will be necessary to understand the Cyclops not only as Pan-Hellenic, but also as a Sicilian phenomenon; it will be necessary to understand the Cyclopea not only as a part of the literary tradition, but as an oral-traditional tale with a degree of independence from Homer and subsequent literary authors. In the literary realm, we will focus our review on the most influential depictions: those of Homer, Euripides and Philoxenus. ${ }^{339}$ After examining Theocritus' engagement with prior literary traditions, this chapter will also seek to understand the story of Polyphemus and Galatea in the context of local Sicilian, sub-literary traditions. The questions I hope to answer by studying both the literary and subliterary traditions of the Cyclops are essential to understanding Polyphemus as Theocritus depicts him: How does the Polyphemus of Idylls 11 and 6 compare to previous depictions? How does Theocritus navigate the competing versions of Polyphemus, both literary and sub-literary? How did the Cyclops come to be associated with Galatea, as he is in Theocritus? Is the Cyclops, like Daphnis, an emblem of Doric Sicilian identity?

\footnotetext{
${ }^{338}$ Lowenstam (2008) 17 argues that scenes of the blinding of Polyphemus were significant to colonists since they "emblematize not only the dangers and anxieties of foreign travel but also the resolve to overcome unexpected adversity through courage and guile."

${ }^{339}$ Since a recent dissertation by Kostopoulou (2007) has helpfully discussed every depiction of Polyphemus from Homer through the Hellenistic age, there is no need to examine each appearance of the Cyclops between the Odyssey and the Idylls. See also Cusset (2011) 29-44 for a recent review of Cyclopes in literature.
} 


\section{THE CYCLOPS IN HOMER}

We will begin where the poetry begins, with Homer. In the Odyssey, Polyphemus is monstrously large (9.187-192) and has a correspondingly mighty strength (9.240-243). He is isolated and lawless $(9.188-189,215)$. He does not care for Zeus or the other gods (273-278), and he consciously rejects the customary rules of hospitality enforced by that god $(277-278,370)$. As if to reinforce the message that he is generally large and ignorant of proper mealtime etiquette, the poet singles out his huge stomach and correspondingly enormous appetite. He has a huge stomach (296) and his appetite is enormous and barbarous. Not only does the Cyclops drink unmixed milk (297), but he is ignorant of the power of wine (355-362). He eats Odysseus' men two at a time $(289,344)$, and Odysseus compares his beastly manner of eating — bones, entrails and all— to that of a mountain lion (292-293). Polyphemus is a disgusting glutton, consuming so much human flesh and getting so drunk that he passes out and vomits up portions of his gruesome meal (373-374). Homer also characterizes the Cyclops by his stupidity. Not only is he susceptible to Odysseus' attempts to get him drunk, but he also falls for the "Noman" trick (356370, 403-412), and is deceived by the hero's plan for his men to escape by hiding under sheep when the monster lets them out to pasture (422-461). These negative traits should not eclipse the fact that Polyphemus has some strangely human, even sympathetic tendencies, as well. The Cyclops' cave and herd are strangely well-organized, he has plenty of wicker baskets full of cheese (218-223, 244-249), and he makes a genuinely pitiful speech to his favorite ram about his sorry fate (447-460). ${ }^{340}$ But Homer leaves an overall impression of his barbaric monster Polyphemus as violent, gluttonous, stupid and inhospitable.

\footnotetext{
${ }^{340}$ For another recent description of Polyphemus' character in Homer, see Kostopoulou (2007) 1-15.
} 
As Reece has noted, Odysseus' description of the Cyclops takes on the status of a mythological exemplum in the Odyssey. ${ }^{341}$ The hero narrates his encounter with Polyphemus to the Phaeacians, who were driven from their former home near the island of the Cyclopes by their ferocious neighbors (6.1-8), and who, like the monster, are descendants of Poseidon (7.46-68). Despite their shared descent and place of origin, however, the Phaeacians are completely opposed to the Cyclopes in the matter of hospitality (xenia): while the Cyclops is paradigmatically inhospitable, the Phaeacians go to great lengths to ensure the comfort of their guest. ${ }^{342}$ Reece argues that the opposition between the Phaeacians and the Cyclops emphasizes the purpose of Odysseus' narration of the Cyclopea: Odysseus offers up the story of Polyphemus as a protreptic exemplum to the Phaeacians of perverted hospitality, to ensure that they will not treat him badly. ${ }^{343}$ The exemplary status of the Cyclops persisted in later authors, and will be one of the keys to interpreting Idylls 11 and 6.

\section{EURIPIDES'CYCLOPS: SICILY AND SOPHISTRY}

The main characteristics of Polyphemus as he first appears in Homer remain largely the same in subsequent literary tradition: before Theocritus and the Hellenistic age, the ogre is consistently portrayed as violent, gluttonous, stupid and inhospitable. ${ }^{344}$ The depiction of any one

341 (1993) 203-204.

${ }^{342}$ Reece (1993) 203.

${ }^{343}$ Reece (1993) 203-204, with n. 15.

${ }^{344}$ The following discussion of Polyphemus in Euripides and Philoxenus will amply demonstrate that those authors continue to play up Polyphemus' gluttony, stupidity, violence and lack of hospitality. Here I note other instances of those same qualities outside Euripides and Philoxenus. On Polyphemus as a glutton or gourmand, see, for example: Epicharmus' Cyclops, 70-72 K-A. These are the only remaining fragments of that comedy, but they all have diet as their subject. Of the Athenian poet Aristias' satyr play Cyclops, only a single fragment remains (4 Nauck), in which the speaker objects that mixing water into wine ruins it. The focus on food and drink continues in the Odysses, by the Old Attic Comic poet Cratinus (frr. 134, 142-143, 147-148 Kaibel), where the Cyclops possesses a comically sophisticated palate. See also Antiphanes 130-131 K.-A., in which Polyphemus enumerates a long list of fish, cheese and meat. Olson (2007) 130 suggests that the Cyclops here imagines preparations for the wedding he hopes will take place: if Galatea and her Nereids will provide the fish, the Cyclops will provide meat and cheese. On the stupidity of Polyphemus, see: Nicochares (4-5 K.-A.) and Alexis, Galatea 36 K.-A., in which Polyphemus is said to have 
of these characteristics may vary in tone: in comedic depictions, for instance, the monster's gluttony may veer into gourmandise, or his stupidity may slip into crass or incompetent Sophistry. Even these variations in tone, however, depend upon the Homeric background for their humor, so that the underlying traits of Polyphemus' personality remain basically unchanged.

As Rosen has pointed out, Euripides' depiction of Polyphemus is a morally simplistic tale of good (Odysseus) versus evil (Polyphemus). ${ }^{345}$ The evidence from $5^{\text {th }}$ - and $4^{\text {th }}$-century poets, "suggests that Odysseus was usually cast as the unambiguously wronged party, and the Cyclops as the unjust aggressor." ${ }^{346}$ If Homer was willing to arouse some sympathy for the monster (as during Polyphemus' speech to his favorite ram [9.446-461]), $5^{\text {th }}$ - and $4^{\text {th }}$-century poets are much starker in their hostility towards the Cyclops, making the Polyphemus easy to laugh at and giving "the moral high ground" to Odysseus. ${ }^{347}$ As such, the negative characteristics present in the Homeric Cyclopea were also important to Euripides' version of the episode. ${ }^{348}$ Despite this continuity with the Homeric tradition, Euripides is the first literary evidence for one important innovation: the setting of the Cyclopea is now firmly located in Sicily.

Like the other depictions, Euripides' Polyphemus is inhospitable, gluttonous, and violent. ${ }^{349}$ This trio of unattractive traits is, once again, best summed up in the monster's desire to eat his guests (241-249):

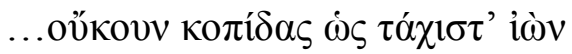

enlisted the services of a sophist, but to have learned nothing from him. For more on the latter fragment, see Arnott (1996) 141. On the violence of Polyphemus, see: Cratinas, 143 Kaibel (anthropophagy) and Alexis, Galatea 36 K.A., in which Polyphemus is said to have ripped out the windpipe of his Sophistry teacher (see Arnott [1996] 146-147 for context). On the inhospitable nature of Polyphemus, see: Cratinus, 143 Kaibel, in which the Cyclops proposes to eat his guests.

345 (2007) 142-143.

${ }^{346}$ Rosen (2007) 142.

${ }^{347}$ Rosen (2007) 143.

${ }^{348}$ For a useful overview, see Kovacs (1994) 53-57.

${ }^{349}$ See note 344. 


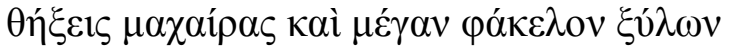

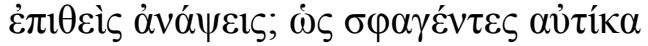

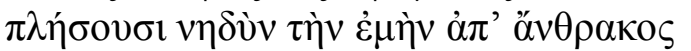

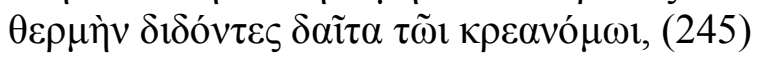

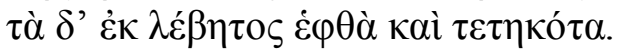

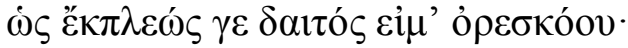

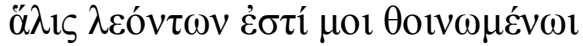

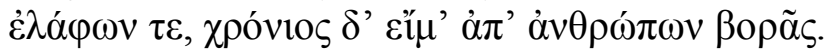

You there, go on the double and sharpen my carving knives and start a big bundle of wood blazing on the hearth. They shall be slaughtered at once and fill my belly, giving the server a feast hot from the coals and the rest boiled and tender from the cauldron. I have had my fill of mountain fare: I have dined enough on lions and deer and have gone far too long without a meal of man's flesh. (trans. Kovacs)

Polyphemus is still a barbaric devourer of men, but, as in Cratinus (143 Kaibel), his tastes have nonetheless grown more sophisticated. ${ }^{350}$ The Cyclops gives precise instructions to Silenus regarding the types of preparations necessary to prepare his dinner. He is tired of rustic, mountain fare and looks forward to variety which his meal of men will provide - in short, the monster has become a gourmand, if a brutal one. ${ }^{351}$

Much as Polyphemus' gluttony takes on a more sophisticated air in Euripides, so his enthusiasm for drink appears to be modeled on aristocratic practices. After having been given wine by Odysseus, the monster is inspired to go on a kōmos. ${ }^{352}$ As he enters at 487, prompted by

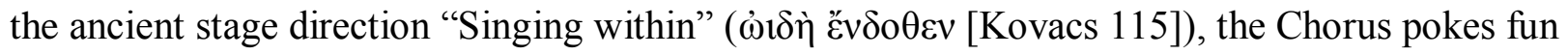
at his clumsy efforts to sing:

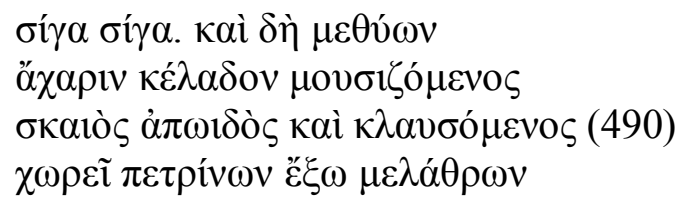

Hush! Hush! For now the Cyclops, drunk and making graceless melody, comes forth from the rocky cave, a singer who is inept and who shall pay dearly. (trans. Kovacs)

\footnotetext{
${ }^{350}$ See note 344 .

${ }^{351}$ On these matters, see also Kostopoulou (2007) 23-24.

${ }^{352}$ On the kōmos and komast dancers, see Smith (2010), esp. 1-13.
} 
The Cyclops exults in the newfound joys of drunkenness and the Chorus reacts:

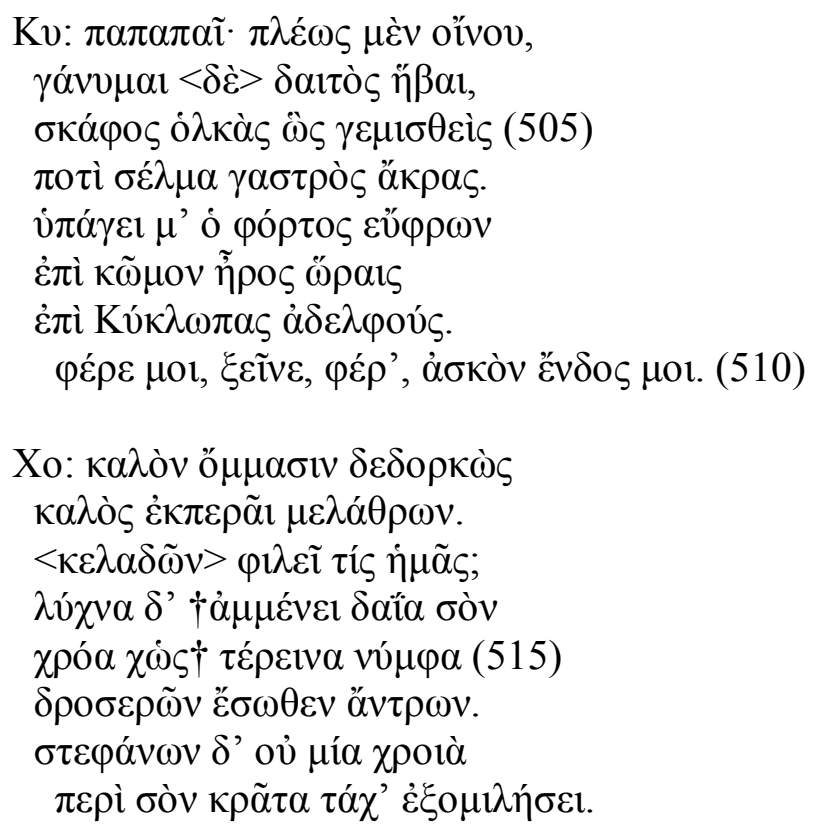

Cyclops: Ooh la la! I'm loaded up with wine, my heart skips with the cheer of the feast. My hull is full right up to the top deck of my belly. This cheerful cargo brings me out to revel, in the springtime, to the houses of my brother Cyclopes. Come now, my friend, come now, give me the wineskin.

Chorus: With a lovely glance he steps forth in beauty from the halls <crying,> "Someone loves me." Don't wait for the hour of lamplighting: $<\ldots . .>$ and a slender nymph are within a dewy cave. But it is crowns of more than one hue that will soon hold converse with your brow. (trans. Kovacs)

Polyphemus not only uses the word kōmos (508), but seeks to assemble the group of revelers typical of such an affair. He also asks for the wine skin, another typical feature of the revel. Moreover, as Polyphemus has been singing and describing his elation, the Chorus has been recounting the blessings of a typical komast. ${ }^{353}$ In 495-502, the satyrs fondly sing of the combination of the kommos with the paraclausitheron, and of the beloved, perfumed hetaera behind closed doors. Then, in 511-18, despite the difficulty of the text, the chorus of satyrs seems to address itself directly to Polyphemus: "Don't wait for the hour of lamplighting:... and a

\footnotetext{
${ }^{353}$ On which see Smith (2010) 2-3.
} 
slender nymph are within a dewy cave" (Trans. Kovacs). It seems that the Chorus encourages the Cyclops to go on a kōmos, ending in a paraclausithyron at the door of a nymph. ${ }^{354} \mathrm{Just}$ as Polyphemus has become something of a gourmand, so his newfound love of drink appears to mimic contemporary Athenian practices. What has not changed, however, is the characterization of Polyphemus as a glutton. Just as in previous treatments of the Cyclops, there is emphasis on Polyphemus' consumption of food and wine.

Moreover, a feature not seen in treatments of the Cyclopea previous to Euripides comes to light in the above passage: the Cyclops seems to suffer from unrestrained sexual desire, as evidenced also by his speech at 577-584, where he is on the verge of taking Silenus to bed to serve as his Ganymede and declares his preference for males over females. ${ }^{355}$ Polyphemus' appetites for food and sex will be important to keep in mind during the discussion of the Cyclops poems of Philoxenus and Theocritus.

Another Euripidean innovation is the poet's use of the Cyclops to satirize sophistic attitudes. Just as Philoxenus would later use the negative qualities of Polyphemus to skewer the contemporary political figure Dionysius, ${ }^{356}$ so Euripides aligns the monster—-traditionally associated with stupidity—with rhetoric, a subject of at Athens in the late $4^{\text {th }}$ and $3^{\text {rd }}$ centuries. ${ }^{357}$ Thus, fashionable, sophistic views are equated with monstrous stupidity. (The monster's attachment to ostensibly sophisticated logic, however, does not make him any less susceptible to the Noman trick [671]). When Odysseus hears that Polyphemus plans to make a meal of him and his companions, he attempts to dissuade the monster from his decision by invoking respect for

\footnotetext{
${ }^{354}$ Polyphemus interest in visiting a nymph is worth noting here, as it precedes Philoxenus' introduction of Galatea to literary treatments of the Cyclopea. Stories of the Cyclops' love for a nymph may well have been in circulation prior to Philoxenus' Cyclops, as will be discussed below, 164-172.

${ }^{355}$ See also Kostopoulou (2007) 27.

${ }^{356}$ Below, 134-143.

${ }^{357}$ Kennedy (1994) 6-8. See also Walde's article in Brill's New Pauly, s.v. "Rhetoric [III.B.2]."
} 
the gods and the law of hospitality (285-312). But the Cyclops has no interest in these matters. Instead, as Kovacs ${ }^{358}$ and Gutzwiller ${ }^{359}$ have pointed out, the Cyclops responds as if he were a stereotypical devotee of the Sophists (316-346). He claims that money is the god of the wise (o

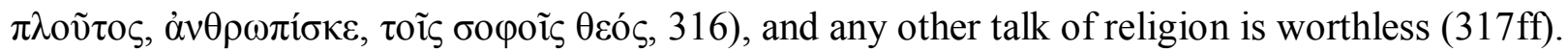
He looks out only for himself, seeking pleasure in material satisfactions: he feeds his flocks on the earth, which produces fodder automatically, and uses his cattle only for his own fulfillment, making a god of his belly (332-335):

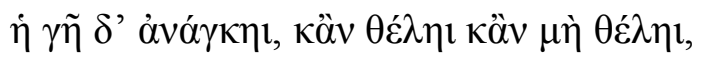

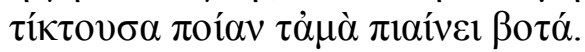

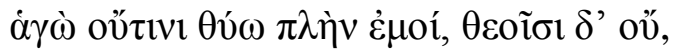

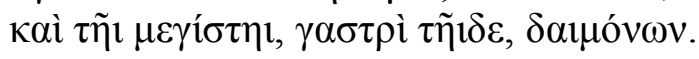

The earth brings forth grass willy-nilly to feed my flock. These I sacrifice to no one but myself - never to the gods - and to my belly, the greatest of divinities. (trans. Kovacs)

The Cyclops ignores Zeus and religion, in favor of monetary gain and his own desires, attitudes typically associated with contemporary Sophists. ${ }^{360}$

The focus on Sophistic rhetoric adds a special importance to the Sicilian setting of Euripides' Cyclops (line 62 and passim). ${ }^{361}$ The supposed inventors of rhetoric, Corax and Tisias, were both from Syracuse. ${ }^{362}$ Sophistic speech apparently came into vogue in Athens following Gorgias' visit to the city on behalf of his native Leontini, in Sicily, following which he took on Athenian students and became widely influential. ${ }^{363}$ Thus, by associating Sophistry with the

\footnotetext{
358 (1994) 56.

359 (1991) 61-63.

${ }^{360}$ Kovacs (1994) 56; Gutzwiller (1991) 61-63. The fullest expression of the destructive outgrowth of these ways of thinking may be Callicles, the young Athenian gentleman who hosts Gorgias in Plato's dialogue of that name (cf. Kovacs [1994] 56).

${ }^{361}$ Later on, Alexis (36 K-A) will make the Cyclops a student of the Sophist Aristippus.

${ }^{362}$ See Baumhauer's article in Brill's New Pauly, s.v. "Corax [3]." See also Cole (1991), who argues that Corax and Tisias were the same person.

${ }^{363}$ See Walde's account of the history of Rhetoric in Brill's New Pauly, s.v. "Rhetoric," esp. the section "The beginnings of rhetoric in the narrower sense (Tisias to Aristotle)."
} 
Cyclops, Euripides may also be referring to the Sicilian origin of both. If it seems far-fetched to link this sophisticated way of speaking with a barbarous monster, there is a precedent in Aristophanes' Birds (1694-1701): ${ }^{364}$

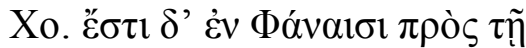

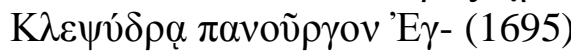

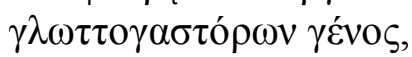

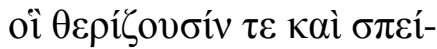

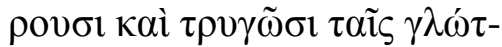

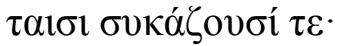

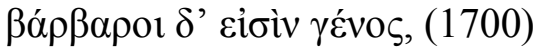

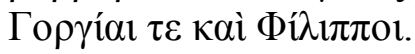

At Phanae, near the Clepsydra, there dwells a people who have neither faith nor law, the Englottogastors, who reap, sow, pluck the vines and the figs with their tongues; they belong to a barbaric race, and among them the Philippi and the Gorgiases are to be found. (trans. O'Neill)

Aristophanes associates Gorgias with barbarism; Euripides links Sophistry, which was Sicilian in origin, with the barbarous Sicilian monster Polyphemus. The new style of speech must have seemed to some Athenians like a foreign invasion, turning young Athenians into selfish monsters. Euripides' focus on the Cyclops' selfishness and greed for money is especially relevant in light of contemporary commentary regarding Gorgias. In the Greater Hippias it is reported (Gr. Hippias 282d) that Gorgias, along with Prodicus, made more money than people working at any other craft. Isocrates, too, mentioned the enormous amounts of money that Gorgias earned (Antidos. 15.155-156) and lambasted him for his selfishness (Sophists 13.2). ${ }^{365}$ The Cyclops, then, as in Homer, remains a creature of uncontrolled appetites: he is violent, stupid and gluttonous, and inhospitable. However, now that the monster is associated with Sicily, he also takes on a new role, as a stand-in for negative aspects of Sicilian culture:

\footnotetext{
${ }^{364}$ On these lines, see Consigny (2001) 96.

${ }^{365}$ On these passages see Consigny (2001) 96.
} 
Euripides uses the Cyclops to attack Sophistry, a contemporary phenomenon with Sicilian origins.

\section{PHILOXENUS' CYCLOPS: GALATEA AND DIONYSIUS I}

The basic outline of the Polyphemus episode familiar from the Odyssey, as well as previous and subsequent literature, remains largely consistent in Philoxenus' dithyramb Cyclops (also known by the alternate title of Galatea): ${ }^{366}$ it recounts the imprisonment of Odysseus, his confinement in the cave and dialogue with Polyphemus, followed by the blinding of the Cyclops. ${ }^{367}$ Philoxenus does appear to innovate, however, in two important ways: first, Philoxenus adds a female character to the story of Polyphemus; second, as one associated with the court of Dionysius I, he introduces the element of political satire into the plot of the Cyclopea.

Philoxenus is the first literary author to treat Polyphemus' love for the nymph Galatea in his dithyramb Cyclops. The ogre's love for the nymph even inspires Polyphemus to make music. $P M G 822$ is apparently a lament that the Cyclops sings to himself, presumably to quiet his love for Galatea. ${ }^{368} P M G$ 821, moreover, is most likely part of a song addressed by Polyphemus directly to Galatea $(P M G 821=$ Athen. 13.564e):

\footnotetext{
${ }^{366}$ Hordern (2004) 285; (1999) 445. What little of Philoxenus' poem has survived is collected by Page (PMG 81524), and basic questions about its date of composition, plot, tone and reception have recently been addressed in a pair of useful articles by Hordern (2004) 285-292 and (1999) 445-455.

${ }^{367}$ Testimony from the Suda confirms that PMG 823 was addressed by the Cyclops to Odysseus, suggesting that, as in the Odyssey, part of the episode was a dialogue between the monster and his captive (Suda, s.v. है $\theta 0 \sigma \alpha \varsigma$,

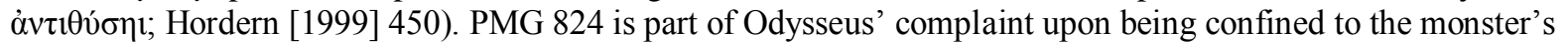
cave, according to Zenobius (Cent. 5.45; Hordern [1999] 450). Clearly, therefore, Odysseus finds himself trapped in the cave of the Cyclops in Philoxenus' dithyramb, as he was in Homer. Both Homer and Philoxenus end the episode

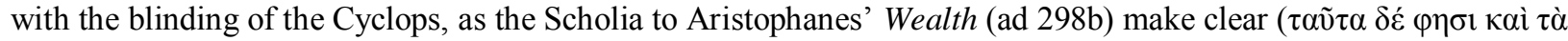

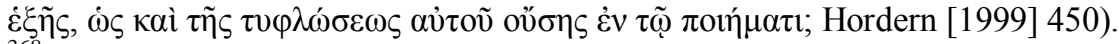

${ }^{368}$ Hordern (1999) 451; Scholia to Theocritus 11.1-3b; Plu. Quaest. Conviv. 1.5.1; Plu. Amator. 18.
} 


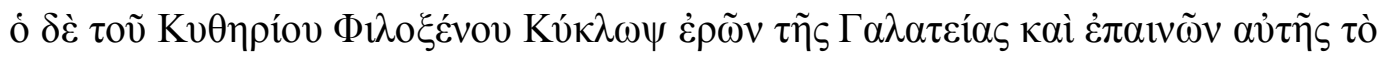

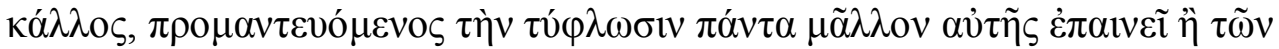

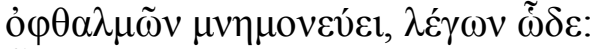

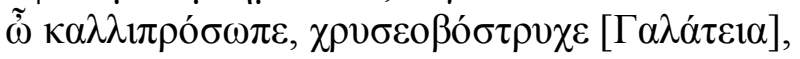

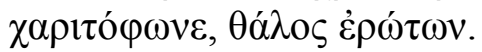

But the Cyclops of Philoxenus of Cythera, in love with Galateia, and praising her beauty, and prophesying, as it were, his own blindness, praises every part of her rather than mention her eyes, which he does not; speaking thus:

O Galateia, with the beauteous face and golden hair, Whose voice the Graces tune, true flower of love (trans. Yonge, with modifications)

The focus on the monster's musicality is in itself innovative. Although Homer's Cyclops does whistle as he drives his flocks from the cave towards their pasture, ${ }^{369}$ music is far more prominent in Philoxenus' dithyramb. In addition to the fragment quoted above, $P M G 819.1$ $\left.(\theta \rho \varepsilon \tau \tau \alpha v \varepsilon \lambda)^{\prime}\right)$, as we know from the Scholia to Aristophanes' Wealth, is an onomatopoetic musical phrase from Philoxenus' Cyclops, from a scene in which Polyphemus plays the cithara. Polyphemus' musicality in Philoxenus may owe something to the komastic song the monster sings in Euripides' version of the Cyclops.

As Hordern notes, ${ }^{370}$ it is not easy to understand exactly what role Galatea might have played in Philoxenus' dithyramb. It is not clear whether she was present in the dramatic action of the poem, or whether she was simply the subject of dialogue, the absent object of erotic longing, as in Theocritus 11. While it will not be possible to answer these questions, $P M G 818$ (= Synesius Ep. 121) offers some idea of Galatea's function in the dithyramb, whether she was present in the action of the poem or not. While $P M G 818$ may reflect the influence of Middle and New Comedy's accounts of the Cyclops, it has long been suggested that its outlines go back to Philoxenus. ${ }^{371}$ In this fragment, which will be taken up again later, ${ }^{372}$ Odysseus poses as a

\footnotetext{
${ }^{369}$ Od. 9.315; Hordern (1999) 451.

370 (1999) 450-451.

${ }^{371}$ Hordern (1999) 451; Holland n.18 192-196.
} 
wizard. He promises Polyphemus that he will bewitch Galatea on the monster's behalf, and make her fall in love with him, if only the Cyclops will release him from the cave:

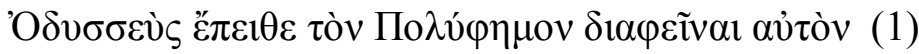

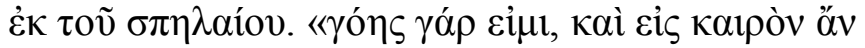

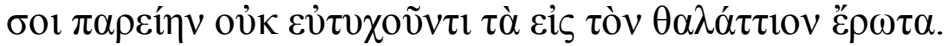

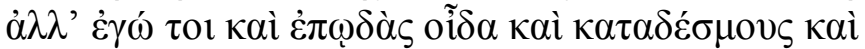

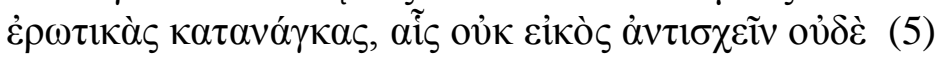

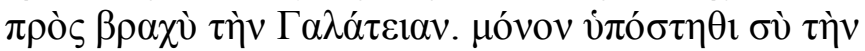

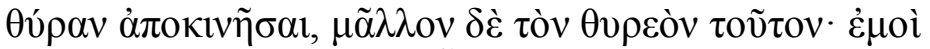

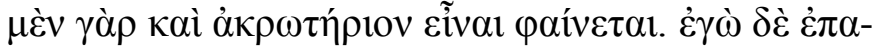

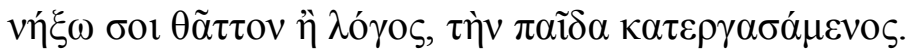

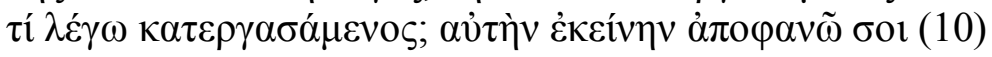

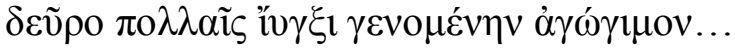

Odysseus was trying to persuade Polyphemus to let him out of the cave: 'for I am a sorcerer', he said, 'and I could give you timely help in your unsuccessful marine love: I know incantations and binding charms and love spells which Galatea is unlikely to resist even for a short time. For your part, just promise to move the door — or rather this door-stone: it seems as big as a promontory to me — and I'll return more quickly than it takes to tell, after winning the girl over. Winning her over, do I say? I'll produce her here in person, made compliant by many enchantments. (trans. Hordern 2004)

But Polyphemus merely laughs at Odysseus' suggestion, and tells him he'd better come up with

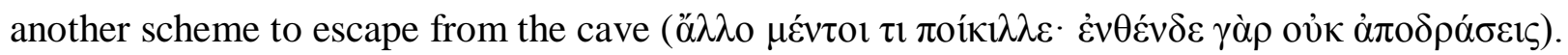
The scheme to bewitch Galatea, then, fills an interlude between Odysseus' imprisonment and his plan to blind the Cyclops. Given frr. 821-822, which must have taken Polyphemus' love for Galatea as their subject, the monster's romantic longing must have played a larger role in Philoxenus' dithyramb than Synesius' epitome suggests. However, the fact that Synesius' summary of the story reduces Polyphemus' love for the nymph to an interlude may suggest that the story of their romance was not a main focus of Philoxenus' dithyramb. ${ }^{373}$ The focus upon

\footnotetext{
${ }^{372}$ Below, 171-172.

${ }^{373}$ Cf. Hordern (1999) 451.
} 
Polyphemus' erotic longing, then, and the reduced emphasis on Odysseus, would be an important Theocritean innovation (more on that elsewhere). ${ }^{374}$

$P M G 818$ also indicates that the attempts of the Cyclops to woo Galatea were unsuccessful. All the evidence indicates that Galatea rejects the offer of Polyphemus: we possess only fragments in which the monster serenades the nymph in an effort to seduce her ( $P M G$ 821-

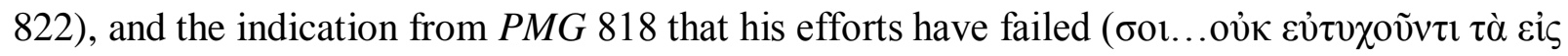

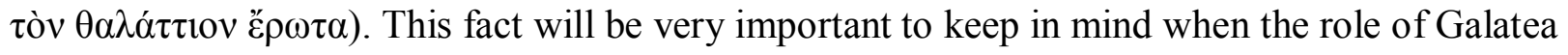
is discussed below.

Philoxenus' introduction of Galatea into the Cyclopea appears to have met with some success. Several authors of Middle Comedy include the nymph in their portrayals of the Cyclopea. ${ }^{375}$ Unfortunately, the evidence is too sparse to draw many conclusions about the role that she plays in those authors. What limited evidence remains of Galatea's attitude toward her one-eyed suitor suggests that the nymph rebuffs his advances, as was probably the case in Philoxenus. $^{376}$

The second of Philoxenus' innovative additions to literary treatments of the Cyclopea is his focus on the element of political satire. Euripides had already used the Cyclops to satirize aspects of contemporary Athenian intellectual life, comparing Sophistry to monstrous, barbaric greed; but the Cyclops of Philoxenus appears to have had a more thoroughgoing satirical intent.

\footnotetext{
374 Below, 150-155.

${ }^{375}$ See the Galatea by the Attic playwright Nicochares; the Cyclops of Antiphanes; the Galatea of Alexis. On these frr. see Kostopoulou (2007) 47-53. On Antiphanes, see Olson (2007) 130; on Alexis, see Arnott (1996) ad loc.

${ }^{376}$ In two fragments of Nicochares (4-5 K.-A.), a speaker depicts the Cyclops as stupid. According to Kostopoulou (2007) 48-49, these lines most likely belong to Galatea and represent her characterization of the Cyclops. Regarding a second pair of fragments, Antiphanes 130-131 K.-A., Olson (2007) 130 argues that Polyphemus, imagining preparations for the wedding he hopes will take place, catalogs various items of food: if Galatea and her Nereids will provide the fish, the Cyclops will provide meat and cheese. According to Olson, Polyphemus comes off "as a hopelessly unreflective bumpkin who has no chance of getting the girl he wants" (Olson [2007] 130). For a different view, see Kostopoulou (2007) 50 who says "Galatea and Polyphemus seem to be in [sic] good terms, a hint that reveals nothing of the subsequent turn of events according to which Galatea will be scornful of the Cyclops.”
} 
Much as Odysseus positions Polyphemus as an implicit exemplum of inappropriate behavior in order to spur the Phaeacians toward proper xenia, so Philoxenus would make the Cyclops an explicit paradigm of stupidity, gluttony, violence, and lack of hospitality when he used the monster to satirize Dionysius I of Syracuse. A number of sources inform us that Philoxenus was court poet of Dionysius, and, in fact, that the two were friends before their relationship degraded, forcing the poet to flee from Sicily. It was after Philoxenus' expulsion from the court that he composed his dithyramb Cyclops, most likely for an Athenian audience. ${ }^{377}$ The earliest evidence for this tradition comes from the historian Phaenias (375-300 BC), via Athenaeus:

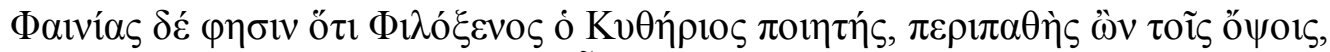

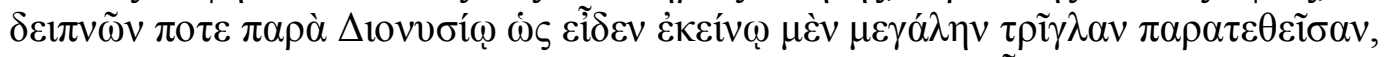

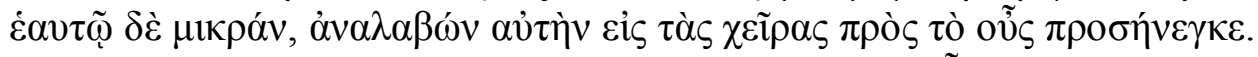

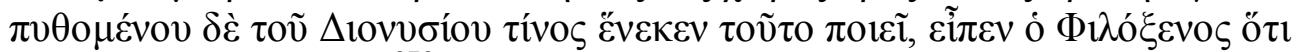

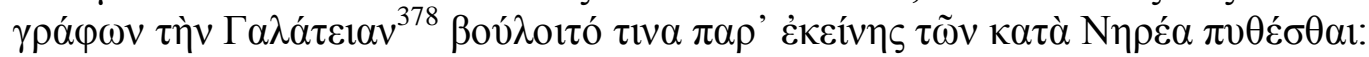

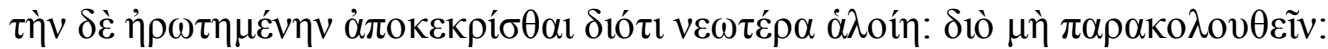

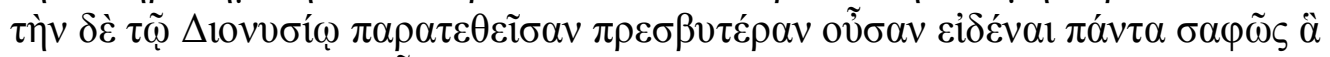

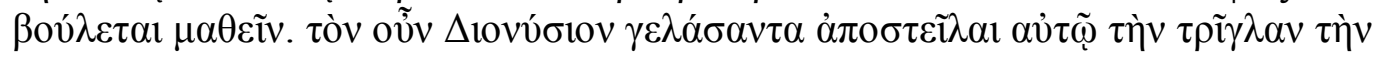

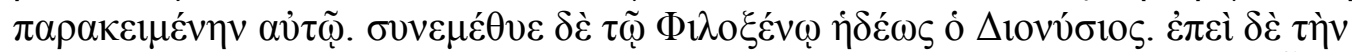

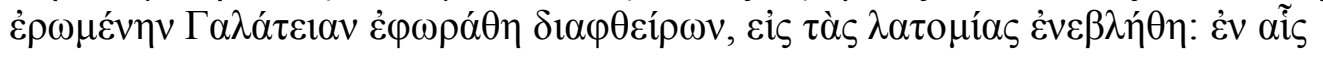

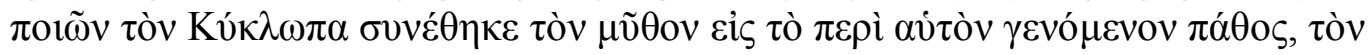

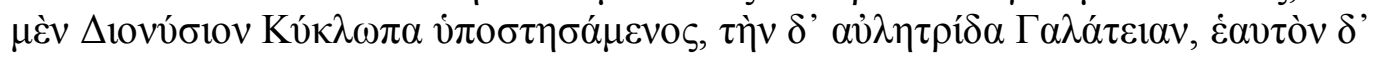

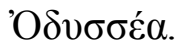

(Phaenias fr. 13 Wehrli $=P M G 816=$ Athenaeus 1.6f-7a).

Phaenias says that Philoxenus of Cythera, a poet, who was exceedingly fond of eating, once when he was dining with Dionysius, and saw a large mullet put before him and a small one before himself, took his up in his hands and put it to his ear; and, when Dionysius asked him why he did so, Philoxenus said that he was writing Galateia, and so he wished to ask the fish for some of the news in the kingdom of Nereus; and that the fish which he was asking said that he knew nothing about it, as he had been caught young; but that the one which was set before Dionysius was older, and was well acquainted with everything which he wished to know. On which Dionysius laughed, and sent him the mullet which had been set before himself. And Dionysius was very fond of drinking with Philoxenus; but when Philoxenus was detected in trying to seduce the king's mistress Galateia, he threw him into the stone quarries. While there he wrote the

\footnotetext{
377 On Philoxenus' performance of the dithyramb in Athens, see Hordern (1999) 445 and Hunter (1999) 216-217; Webster (1970) 20-21.

${ }^{378}$ Note that here the Cyclops is referred to by its alternate name, Galatea.
} 
Cyclops, constructing the fable with reference to what had happened to himself; representing Dionysius as the Cyclops, and the flute-player as Galateia, and himself as Odysseus. (trans. Yonge)

Much the same story is found in several other sources: ${ }^{379}$ Philoxenus supposedly composes the satirical Cyclops as revenge for his poor treatment at court. The connection between Dionysius and the Cyclops would have been an apt one, given Sicily's identification as the land of the Cyclopes since at least the $5^{\text {th }}$ century (Thucydides 6.2.1, Euripides, Cyclops, passim).

Some scholars doubt the veracity of this anecdote, and it should not be accepted without qualification, but, as Rosen notes, ${ }^{380}$ whether the story is true or false, the more important matter is that ancient sources treated it as true. Phaenias (circa 375-300 BC), our first evidence for the satirical reading of Philoxenus' dithyramb, was born not even a generation after the first performance of the poem. ${ }^{381}$ Ancient readers, therefore, may have connected the depiction of Polyphemus in the Cyclops with Dionysius from an early date, which indicates that the dithyramb was, at the very least, open to a satirical interpretation. ${ }^{382}$ Even if the dithyramb did not openly mock the tyrant, ancient critics apparently believed that it did. Theocritus, when he composed his own Cyclops poems a century later, would most likely have been aware of the satirical association between Dionysius and Polyphemus, especially given the hostile anecdotal tradition that developed about the Syracusan tyrant. ${ }^{383}$

\footnotetext{
${ }^{379}$ See Hordern (1999) 446, who cites Diod. 15.6; Machon fr. 9 Gow; Sopater fr. 23 Kaibel; Cicero, Att. 4.6.2; Plu. Tranq. 12; Paus 1.2.1; Lucian. Cal. 14; $\Sigma$ Ar. PI. 179; Suda 0 397; Joh. Tzetz." in PI. 290 pp. 83-84 Positano.

${ }^{380}$ Rosen (2007) 158; see also Hordern (1999) 448.

${ }^{381}$ See Gottschalk's article in Brill's New Pauly, s.v. "Phaenias."

${ }^{382}$ Rosen (2007) 158; see also Hordern (1999) 448 and Hunter (1999) 217.

${ }^{383}$ On the anecdotal tradition hostile to Dionysius and largely centered at Athens, see Duncan (2012) 137-143, Caven (1990) 2-5, Sanders (1987) 1-40, Hunter (1983) 116-117. On Philoxenus' part in this tradition, see Caven (1990) 223-224 and Sanders (1987) 15-20. Caven acknowledges a level of hostility toward Dionysius in Athens, but asserts that it was "unlikely to have been confined to Athens" (224). Some scholars have suggested that the satirical depiction of Dionysius may have arisen in Middle and New Comedy, rather than being political in nature, e.g. Webster (1970) 20-21. Cf. Hunter (1999) 217. For a recent discussion of satire of Dionysius in Philoxenus, see Rosen (2007) 155-159.
} 
It is difficult to make claims about the exact nature of that satirical portrait, and the true relation of Philoxenus' dithyramb to the anecdotes that recount its composition. But from what remains of Philoxenus' poem, it appears that the negative aspects of Polyphemus' character remain consistent with those given to him by Homer. It is striking, moreover, that the tradition of hostile anecdotes about Dionysius tends to highlight negative personality traits akin to those attributed to Polyphemus. It is therefore likely, I suggest, that the tradition of hostile anecdotes about Dionysius, which include stories depicting the composition of Philoxenus' Cyclops, may shed some light on the tone and contents of this lost dithyramb. In other words, it appears from the fragments of Philoxenus' dithyramb that the Cyclops continued to be depicted as gluttonous, stupid, violent and inhospitable. These same qualities characterize Dionysius not only in the anecdotes surrounding the composition of Philoxenus' poem, but in other depictions of the tyrant as well. We have, therefore, reasonably strong grounds to claim that the traits associated with Dionysius in the anecdotal tradition, but not straight-forwardly reflected in the fragments of Philoxenus, can nonetheless tell us something about the nature and tone of the satire directed at the tyrant. At the very least, I stress again, later authors appear to have read Philoxenus' Cyclops in that manner.

Like the depiction of Polyphemus in Odyssey 9, the satirical portrait of Dionysius as the Cyclops provides an exemplum of how not to behave. The same negative traits which Homer highlights are also on display in the fragment of Phaenias, as well as the remaining anecdotal tradition surrounding Philoxenus' time in the court at Syracuse. ${ }^{384}$ First of all, the stories of conflict between the tyrant and the poet may be interpreted in terms of hospitality. Philoxenus is a guest at the court of Dionysius. While Philoxenus may not behave in an exemplary manner,

\footnotetext{
${ }^{384}$ For a discussion of the negative traits of Dionysius as portrayed by Philoxenus, see Rosen (2007) 155-159, who comes to a similar conclusion.
} 
supposedly seducing his host's mistress, neither did Odysseus, who invited himself into the Cyclops' cave and helped himself to some of the ogre's cheese. In any event, the tyrant ends up acting violently towards his guest, throwing him into the quarries (very similar indeed to confinement in a cave). This lack of hospitality was likely one of the common characteristics between Polyphemus and Dionysius, highlighted either by Philoxenus himself, or by later interpreters like Phaenias.

Philoxenus also seems to have portrayed Dionysius as witless and an unsuccessful artist. The anecdotes about Philoxenus' time at the court report several reasons for the hostility between the poet and the tyrant. The story quoted above claims that the origin of their enmity was Philoxenus' seduction of Dionysius' concubine, supposedly named Galatea (Phaenias fr. 13 Wehrli $=P M G 816=$ Athenaeus 1.6f-7a). But two other sources claim that the friendship of Dionysius and Philoxenus was endangered by the poet's criticism of his host's literary abilities. Plutarch (Moralia 471e-f) recounts a story that Philoxenus was hauled off to the quarries because of Dionysius' jealousy at being an inferior singer. Diodorus (15.6) reports that Philoxenus was thrown into the quarries after openly mocking the tyrant's poems. The poet's friends beg him off, but after his release, Dionysius again demands Philoxenus' opinion. The poet is able to escape further confinement by resorting to double entendre, tricking the tyrant into thinking his comments are positive, when, in fact, they are derogatory (Diodorus 15.6). Although these two anecdotes are not among the fragments of Philoxenus' Cyclops, they may nonetheless provide some idea of the poem's satirical content, given the fact that they concern the relationship between the dithyrambist and his one-time patron, who is pilloried in it. Especially in Diodorus' account, Philoxenus appears to be a man of superior intelligence taking advantage of a slowwitted opponent with words, like Odysseus deceiving the Cyclops with the "Noman" trick. It 
may be the case, therefore, that these anecdotes reflect Philoxenus' derision of Dionysius' intelligence and poetic abilities in his dithyramb. Dionysius is reported elsewhere to have taken pride in his literary activities. ${ }^{385}$ Several of the fragments of the dithyramb depict the Cyclops singing and playing music out of devotion to Galatea (PMG 819.1, 821-822). If we accept that Dionysius was the satirical target of Philoxenus' poem, then his poetic abilities may have come under fire in such verses. Likewise, Philoxenus would have called the tyrant's intelligence into question simply by associating him with Polyphemus. That the monster's intelligence, or lack thereof, was a source of humor in the dithyramb is clear from $P M G$ 818, in which Polyphemus praises Odysseus' cunning, but claims all the same that his captive will not escape.

Another main concern of the anecdotal tradition surrounding Philoxenus' time at the Syracusan court is food and drink, a central theme of the Homeric Cyclopea and subsequent depictions. Although Phaenias' fragment (fr. 13 Wehrli; $P M G$ 816) calls Philoxenus a gourmand

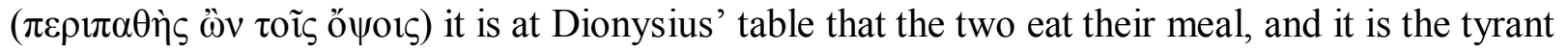
himself who originally is served the larger mullet, hinting perhaps at a gluttonous appetite.

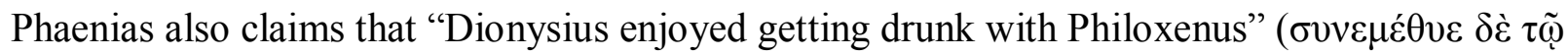

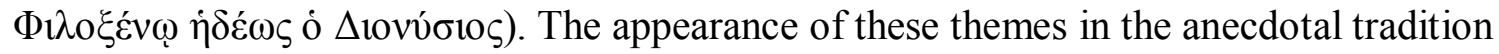
surrounding the composition of the Cyclops indicates that the poem treated these subjects directly, or was interpreted as making a comment about the sumptuousness of the Syracusan court. Direct proof that Philoxenus treated dietary themes is available in three fragments of the Cyclops. ${ }^{386}$ Drunkenness was most likely also a topic of the dithyramb, as indicated by the

\footnotetext{
${ }^{385}$ E.g. Diodorus 15.74. For a discussion of humorous anecdotes about Dionysius as a poet, see Duncan (2012) 140141. On Dionysius as a tragic poet, see Duncan (2012) 143-147.

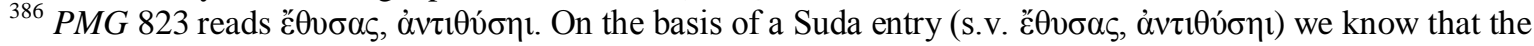
Cyclops spoke these words to Odysseus and was speaking about sacrificing something - perhaps men, but the entry is unclear-instead of sheep. Thus, Polyphemus' dietary habits were a subject of the poem, and perhaps his

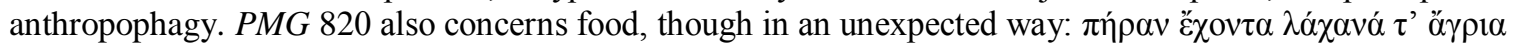
$\delta \rho \circ \sigma \varepsilon \rho \alpha ́$. The scholia to Aristophanes' Wealth (ad 298) report that Philoxenus' Cyclops picked and ate wild greens.
} 
scholia to Aristophanes' Wealth ad 290. The scholia mention that a portion of a song at lines 290-301, in which a group of old rustics mime the Cyclops, is a parody of Philoxenus'

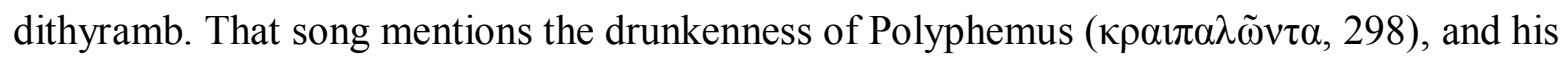
subsequent blinding. Verse 298 of the Wealth, in which the mention of the drunken Cyclops occurs, also contains a fragment of Philoxenus' Cyclops (PMG 820). The scholia (ad 298) indicate, moreover, that the manner in which Aristophanes treats the blinding episode here was lifted from Philoxenus. ${ }^{387}$ It is not surprising that Philoxenus would have mocked the tyrant's reputation as a drunk and a glutton by a comparison to the Cyclops.

The attack on Dionysius from Philoxenus, then, most likely centered upon themes familiar from Homer: poor hospitality, violence, gluttony and stupidity. The attacks leveled at the tyrant in the Cyclops were most likely composed for the amusement of Athenian audience, since the poem was parodied shortly after its composition in the Wealth of Aristophanes (Scholia ad Wealth 290ff). ${ }^{388}$ The repeated mentions of the quarries in which Dionysius supposedly imprisoned his court poet would have been especially effective in an Athenian context. During the disastrous Sicilian Expedition, these same quarries became a nightmarish prison camp for captured Athenians (Thuc. 7.86-87). Whether Philoxenus did in actuality spend time confined to the quarries or not, the detail appears to be designed to illicit Athenian sympathy, while at the same time provoking disgust at Dionysius. ${ }^{389}$

\footnotetext{
The consumption of $\lambda \alpha \dot{\alpha} \alpha \alpha v \alpha$ is used in the Thesmophoriazusae to demonstrate the coarseness of a certain character,

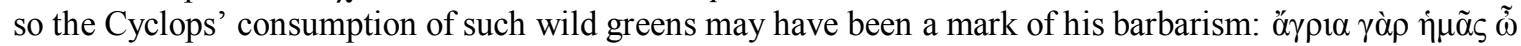

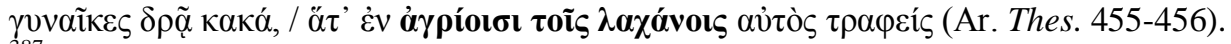

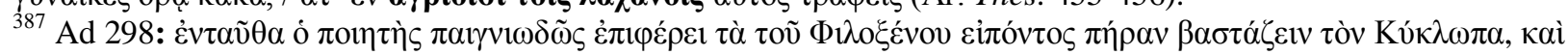

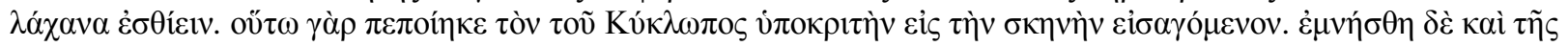

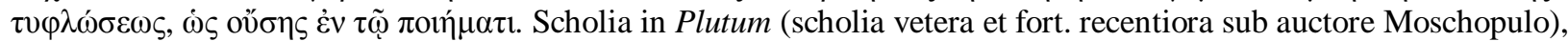
in F. Dübner, Scholia Graeca in Aristophanem. Paris: Didot, 1877 (repr. Hildesheim: Olms, 1969): 323-387.

${ }^{388}$ Hordern (1999) 445; Hunter (1999) 216-217; Webster (1970) 20-21.

${ }^{389}$ Assuming, that is, that the anecdotal tradition reflects the content of the dithyramb in this matter. Caven (1990) 223-224 suggests that the quarries, which are mentioned in all three versions of the spat between Dionysius and Philoxenus, were actually the name of the Cyclops' cave used in the dithyramb.
} 


\section{THE CYCLOPS BEFORE THEOCRITUS:} AN EMBLEM OF SICILY AS SEEN FROM AFAR

As the Athenian Euripides had used the Cyclops to satirize the Sicilian institution of Sophistry, Philoxenus has made the Cyclops his vehicle for attacking and satirizing Dionysius, equating one Sicilian monster with another. ${ }^{390}$ The negative qualities that Homer had attributed to Polyphemus (gluttony, violence, stupidity, inhospitality), now begin to take on specifically Sicilian connotations. As we shall see, some of the qualities for which Philoxenus attacks Dionysius (especially love of food and drink) come to be associated not just with Dionysius, but become emblematic of Sicilian culture more generally, as portrayed by authors composing for an Athenian audience. In this light, let us examine other negative anecdotes about Dionysius and his family, which also focus on his gluttony and drunkenness.

That Philoxenus' dithyramb was part of a larger Athens-based hostility towards Dionysius can be seen first in Aristophanes. ${ }^{391}$ His Wealth (388) not only parodies Philoxenus' Cyclops, which must have been composed in the years leading up to $388,{ }^{392}$ but later in the same play (550), Aristophanes mockingly equates Dionysius to Thrasybulus, implicitly condemning the tyrant by comparing him to the Athenian democratic leader. ${ }^{393}$ It was also in 388 that Lysias spoke out against Dionysius before the entire Pan-Hellenic community, in his Olympic Oration, during a period in which the tyrant's reputation in Athens was at a low point, ${ }^{394}$ presumably on

\footnotetext{
${ }^{390}$ The Cyclops was already, at this point, a resident of Sicily (Thuc. 6.2.1; Eur. Cyclops, passim).

${ }^{391}$ See note 383. Caven (1990) 224 acknowledges a level of hostility toward Dionysius in Athens, but asserts that it was "unlikely to have been confined to Athens."

${ }^{392}$ Hordern (1999) 445.

${ }^{393}$ Sanders (1987) 12. Caven (1990) 222 also mentions Aristophanes' remark as an instance of hostility towards Dionysius at Athens, but does not ascribe to the view that there was a concerted, Athenian, anti-Dionysian movement originating from the city.

${ }^{394}$ 33.5; Caven (1990) 222; Sanders (1987) 11.
} 
account of his supplying ships to the Spartans, who were fighting the Athenians. ${ }^{395}$ Dionysius enjoyed a brief period of rehabilitation in Athens, even winning the Lenaea for his tragedy the Ransom of Hector, an honor perhaps bestowed in an effort to improve relations with the tyrant in the years after Leuctra. ${ }^{396}$ Yet the anti-Dionysian tradition continued, and is probably the source for Plato's vivid depiction in the Republic of the Tyrannical Soul, consumed by its own appetites. $^{397}$

Much of the negative tradition about Dionysius pillories his supposed inability to control his appetites for food and drink. The focus on gluttony in this attack on the tyrant is especially important, since the theme of uncontrollable appetite not only pervades all portions of the literary traditions about Polyphemus, but it also seems to have particular associations with Dionysius and Sicily in general. ${ }^{398}$ The qualities for which ancient commentators criticize Sicily are strikingly similar to those attributed to Dionysius and the Cyclops. In Plato's Republic (404d) the

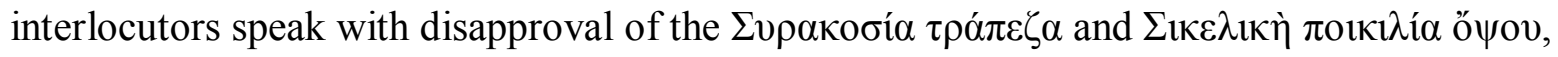
which were proverbial. ${ }^{399}$ Plato's $7^{\text {th }}$ Letter (326bff.) cites the luxuriousness of Sicilian dining as

\footnotetext{
${ }^{395}$ Arnott (1996) 140, note 1. It should be noted that Arnott does not accept the tradition of Philoxenus' imprisonment in Syracuse. Whether the stories are true or not, however, is not as important to our argument as whether they were accepted as true and incorporated into the hostile tradition surrounding Dionysius.

${ }^{396}$ Hunter (1983) 116; Diod. 15.74.1.

${ }^{397}$ Rep. 8.565ff, 9.571ff; Sanders (1987) 21; Caven (1990) 167; Monoson (2012).

${ }^{398}$ We have already discussed the Phaenias fr. 13, which depicts Dionysius at the dinner table, poised to eat a large mullet, and claims he liked to get drunk. Another attack on Dionysius concerning, in part, his dietary habits came from the Athenian comic poet Eubulus, who probably composed his play Dionysius around the time of the tyrant's death (on the difficulties of dating the play, see Hunter [1983] 117). Not much remains of Eubulus' hostile treatment of Dionysius, but the context in which Athenaeus quotes the play gives a sense of the nature of the attack, which accords with the stereotypical picture of tyranny as it appears in the Republic, as concerned with flatterers and appetites (see Hunter [1983] 116-119). First, Athenaeus goes on about Philip's drunkenness and debauchery (260bc) and then, citing Eubulus, claims that Dionysius participated in the same sort of behavior (260c-d). Diodorus likewise condemns Dionysius as a drunkard (15.74.1-4). The tyrant is so overjoyed at the prospect of having defeated poets better than himself in the Lenaea (as Diodorus reports it) that he drinks himself to death. In addition to the tyrant's overzealous love of wine, then, Diodorus also highlights his inferior quality as a poet. Both of these themes have already been discussed in connection with Philoxenus' satirical portrait of the tyrant as Polyphemus, and have their root in the Homeric depiction of the Cyclops as unintelligent and susceptible to drunkenness. The spawn of Dionysius was likewise characterized as a brood of drunks (Athenaeus 435e-436b).

${ }^{399}$ Adam (1963) ad loc.
} 
a formative experience in the philosopher's development. ${ }^{400}$ Athenaeus (527c) quotes

Aristophanes' Banqueters (fr. 225) in a similar vein, citing the lavishness of Syracusan and

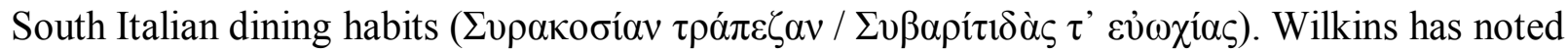
other examples similar to these, and discussed Athenian concern with the influence of Sicilian cooking on the city. ${ }^{401}$ Olson and Sens, in their introduction to Archestratus of Gela's dactylic catalogue-poem on food, note the emergence of Sicilian cookery: Archestratus himself was from Sicily, and "two of the earliest known authors of prose cookbooks, Herakleides of Syracuse and Mithaikos, came from there as well, and from at least the last quarter of the $5^{\text {th }} \mathrm{c}$. on the island's culinary style seems to have been widely known and much imitated." ${ }^{402}$ The proverbial

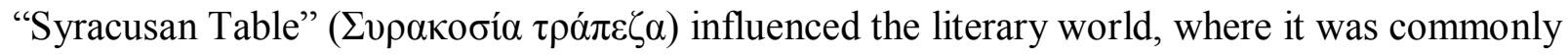
cited, as well as the real world of dining, with the arrival of the prose cookbook from Sicily allowing cooks elsewhere to imitate the elaborate western style. ${ }^{403}$ The Sicilian chef at work in Athens became a comedic commonplace in the $4^{\text {th }}$ and $3^{\text {rd }}$ centuries. ${ }^{404}$ The traits which Philoxenus appropriates from the Cyclops and uses to attack Dionysius, then, also characterize Sicilian culture at large. Since this is the case, it is likely that in Philoxenus' satirical depiction of Dionysius the Cyclops, as a drunk and glutton, would have been understood not only as resembling the tyrant, but also fitting the stereotype of the "typically gluttonous Sicilian."

To sum up the argument thus far, then: Polyphemus, since his first appearance in Greek literature, has had an exemplary quality. In Homer, he embodies negative traits that the

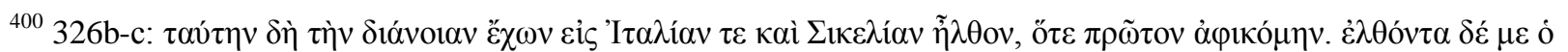

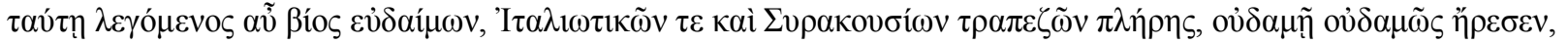

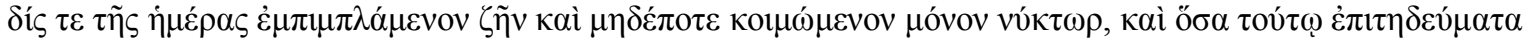

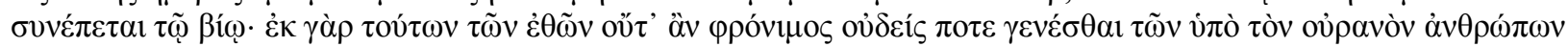

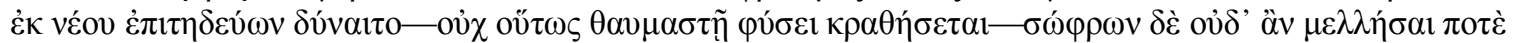
$\gamma \varepsilon v \varepsilon \dot{\sigma} \sigma \alpha \mathrm{ll}_{\ldots} .$.

${ }^{401}$ Wilkins (2000) 316-317, but see also chapter 7, “The Culinary Literature of Sicily.”

402 Olson and Sens (2000) xx.

${ }^{403}$ Olson and Sens (2000) xxxvi . For a fuller description of this process, see Olson and Sens (2000) xxxvi-xxxix.

${ }^{404}$ Dalby (1996) 109, who also discusses Sicilian gastronomy more generally (108-111).
} 
Phaeacians should avoid: violence, stupidity, gluttony and poor hospitality. Philoxenus, too, creates from the character of Polyphemus a type of negative exemplum in his satirical portrait of Dionysius I. The dithyrambist preserves the ill habits of the Cyclops, but makes them the shared characteristics of Dionysius. This shared gluttony of the Cyclops and Dionysius appears to engage with a negative stereotype about Sicily in general, as the proverbial birthplace of an extremely luxurious style of dining. It has already been noted that the Cyclops is put to similar use in Euripides' satyr play, where the Sicilian ogre is associated with the Sicilian art of Sophistry. It is important, as well, that the critiques of Sophistry, Dionysius and of Sicilian diet are intended largely for Athenian audiences, suggesting that the commentary on the island's supposed opulence in speech and diet reflect the attitudes of Athenian authors and audiences toward Sicily. The figure of Polyphemus in Philoxenus' Cyclops, in turn, is an emblem of these Athenian concerns over Sicilian culture and behavior.

\section{POLYPHEMUS IN THEOCRITUS:} AN EMBLEM OF SICILY AS SEEN FROM SICILY

The Idylls in which Theocritus depicts the Cyclops diminish, reverse and erase Polyphemus' negative characteristics, which had come to embody negative aspects of Sicilian culture. Idylls 11 and 6, Theocritus' Cyclops poems, both treat Polyphemus as an exemplum. However, in contrast to Homer, or the satirical depictions of the monster in Euripides or Philoxenus, Theocritus utilizes the Cyclops as a positive exemplum - the Cyclops in Idylls 11 and 6 embodies certain positive behaviors that the poet's addressees should imitate. ${ }^{405}$ This reversal is only one way in which Theocritus sheds a much more sympathetic light on

\footnotetext{
${ }^{405}$ Cf. Rosen (2007) 161, who notes that the Cyclops of Idyll 11 becomes "a sympathetic, positive paradigm," which he attributes in part to the shared homeland of Theocritus and Polyphemus. Cf. also Christoforidiou (2005) 35-38, who discusses the humanization of Polyphemus and his incorporation into the bucolic sphere.
} 
Polyphemus than any previous author. An important structural difference also contributes to the more favorable depiction of Polyphemus. As opposed to depicting the Cyclops in a theatrical setting, these two idylls take the form of personal letters. Thus, the monster is not objectified as an object to be laughed at on stage, as in Euripides; rather he is the centerpiece in each case of the poet's appeal to a friend. Therefore, when Polyphemus sings in each idyll, especially in the case of his monologue in Idyll 11, his language is perceived as being close to the speech of the poet himself, eliciting the sympathies of the reader. ${ }^{406}$

We will begin with Idyll 11, since it comes first in the narrative order. ${ }^{407}$ The Eleventh Idyll is addressed to a friend of the poet, a doctor by the name of Nicias. Whether the verseepistle is intended to console Nicias due to real events in his life, or whether it is an elaborate literary exercise, the opening conveys a sense of intimacy, crafted specifically for the doctor, as if the enclosed poem itself were a charm intended to ward off the ill effects of love, when Nicias' own powers of healing were failing him. It depicts the Cyclops struggling at first with the effects of erotic desire, neglecting his duties. But, with the aid of music ( Polyphemus is able to turn away from infatuation and face life again. This, presumably, is what Nicias should do, too.

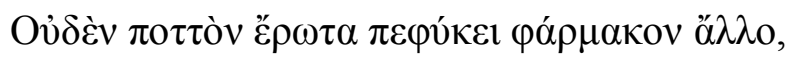

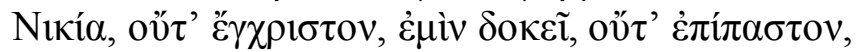

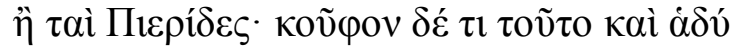

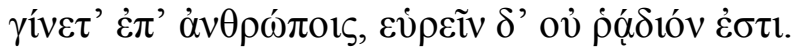

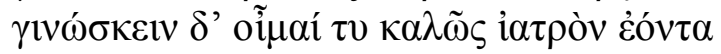

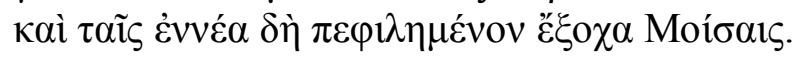

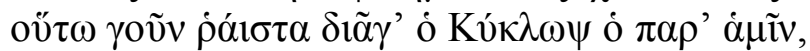

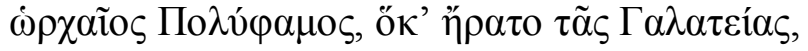

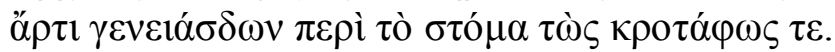

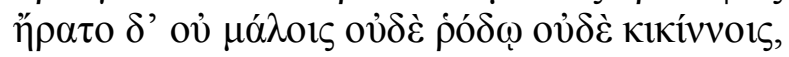

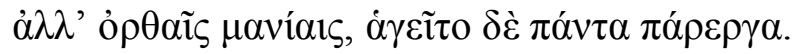

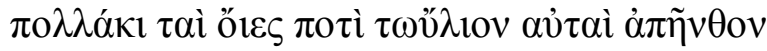

\footnotetext{
${ }^{406}$ For a similar point of view, see Rosen (2007) 161 and Hunter (1999) 219.

${ }^{407}$ Hunter (1999) 244; Gutzwiller (1991) 106-107.
} 


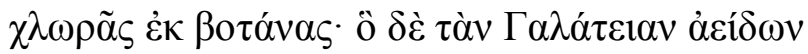

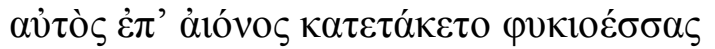

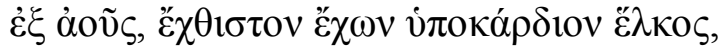

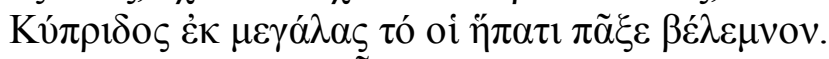

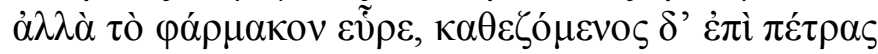

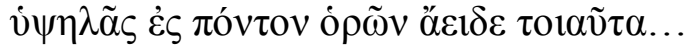

There is no other cure for love, Nicias, neither unguent nor ointment, it seems to me, besides the Muses. This is something gentle and sweet for men, but it is not easy to find. This I think you know full well, since you are a doctor, and very well-loved by the nine Muses. Therefore, I suppose, did the Cyclops, my countryman, old Polyphemus, fare easily when he loved his Galatea, just as he was sprouting his first beard about his lips and temples. But he did not love with apples, nor roses, nor ringlets, but with total madness, and there was nothing else that mattered. Very often his sheep led themselves back to the fold from the green pastures, while he pined away upon the weedy shore, singing of Galatea from the dawn, with a hateful wound beneath his heart, which a shaft of mighty Cypris had fixed in his liver. But he found the cure, and seated upon a high rock overlooking the sea, this is what he sang...

The preface to the poem makes it clear that the idyll's main body is intended as an example for the recipient. In the words of Richard Hunter:

Polyphemus' song (19-72) is preceded by a gnomic opening and address to Nikias (1-6) and the introduction to the narrative exemplum (7-18); the poem closes with a two-verse confirmation of the lesson to be drawn from the paradigm. ${ }^{408}$

The first eighteeen lines of Idyll 11 illustrate several major departures from previous depictions of the Cyclops. Polyphemus is no longer the insatiable monster familiar from previous authorsquite the opposite. He is now able to control his desires by means of song. Moreover, the reader feels immediate sympathy for Polyphemus. Not only will the Cyclops' voice come to replace the authorial voice once his solo song-performance begins (19-72), thus linking Polyphemus with the poet, ${ }^{409}$ but Theocritus has also endeared the monster to us by citing their common place of residence: the poet highlights that both are from Sicily.

\footnotetext{
${ }^{408}$ Hunter (1999) 215. See also Fantuzzi and Hunter (2004) 170-171.

${ }^{409}$ See notes 405-406.
} 
This emphasis on regional identity is freighted with meaning in the context of the previous literary tradition. The Cyclops had long been associated with Sicily (at least since the $5^{\text {th }}$ century [Thuc. 6.2.1; Eur. Cyclops passim]). More than that, however, he had come to symbolize on occasion certain negative characteristics about the island's culture, especially from an Athenian standpoint. Since Theocritus emphasizes their shared Sicilian heritage, the poet's decision to shine a sympathetic light on the monster in the preface to Idyll 11, as well as his characterization of the Cyclops as capable of controlling his appetites, must be read in light of these previous, non-Sicilian depictions of Polyphemus.

That Theocritus' Polyphemus represents innovation by virtue of his sympathetic character can be seen more clearly when we examine particular character traits. Whereas he is marked in earlier treatments by violence, Theocritus instead depicts him as a non-violent lover. The Theocritean portrait stands in contrast to the Cyclops of Philoxenus, where, despite the addition of Galatea, the overall plot structure remains largely Homeric. The Galatea episode in Philoxenus occurs simultaneously with Odysseus visit. Despite the presence of the nymph, Polyphemus still captures and confines Odysseus in his cave, and plans to eat him. ${ }^{410}$ Likewise, in Alexis' play Galatea, Polyphemus apparently made an effort at refinement, but ended up being violent all the same. ${ }^{411}$ In Theocritus, however, all explicit mention of violence is suppressed, and is suggested only by ironic allusion to the plot of the Homeric Cyclopea. ${ }^{412}$ The focus of Idyll 11 is far less on narrative or plot than in its predecessors; instead, Theocritus focuses mainly on the emotional state of the Cyclops, thus diminishing previous (negative) depictions and compelling the reader to sympathize to a far greater extent with the monster. Theocritus' Cyclops even loves with a gentleness free of aggression: he chivalrously concedes

\footnotetext{
${ }^{410}$ See above, page 136 , and $P M G 818$

${ }^{411}$ See above, note 344 and page 132; Alexis fr. 36 K.-A.

412 Below, 154.
} 
that if Galatea will not allow him a kiss on the mouth, he will kiss her hand instead. ${ }^{413}$ The Galatea episode is not conjoined with the visit of Odysseus. Instead, Odysseus disappears from the scene, never mentioned explicitly, but only in allusions. ${ }^{414}$ Polyphemus' love for Galatea, then, is given its own, independent status. ${ }^{415}$

The disinterest of Idyll 11 in the monster's violent side is not only a striking reversal of previous tradition, it may be a way of dissociating the Sicilian Cyclops from the negative tradition surrounding Dionysius I. ${ }^{416}$ Philoxenus had equated the tyrant with the Cyclops, and composed his satirical dithyramb for an Athenian audience, among the first of many negative anecdotes that would come to be associated with Dionysius. Theocritus' depiction of the Cyclops is certainly comic, since he is deliberately up-ending previous negative portraits of the monster. Despite being funny, however, the portrait of the Cyclops in the Idylls is also sympathetic: it steers the reader away from thinking of the one-eyed Ogre as the mythological equivalent of the real-life monster Dionysius, and makes him instead into a gentle fool, or even a preposterous kind of quasi-philosopher, a character more at home in fable or folktale than angry political satire. In this way, the gentle depiction of Polyphemus in Idyll 11 separates him from that tradition, and acts as a tongue-in-cheek recuperation of a Sicilian character by a Sicilian poet. Besides establishing sympathy for the Cyclops and emphasizing his qualities as a lover instead of the violence long associated with him in previous literary tradition, Theocritus alters the character of Polyphemus in a number of other ways. We have seen that prior literary tradition

\footnotetext{
${ }^{413} 55-56$ and Hunter (1999) ad loc.

${ }^{414}$ Cf. Kostopoulou (2007) 58-59, Hunter (1999) 217.

415 The exclusion of Odysseus from the Polyphemus-Galatea episode may have its origin in 4th century comedy, which do not mention him. See Kostopoulou (2007) 53.

${ }^{416}$ Baron (2013) 256 has pointed out what may be a similar Sicily-Athens dynamic in the Sicilian Historian Timaeus, a near-contemporary of Theocritus, who emphasized "the primacy of the western Greeks in political, cultural, and intellectual achievement, some of which was directed at an Athenian audience.”
} 
had associated the Cyclops with gluttony and gourmet cooking. In Idyll 11, however,

Polyphemus' diet is stereotypically pastoral (34-37):

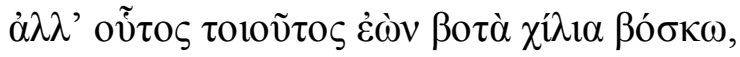

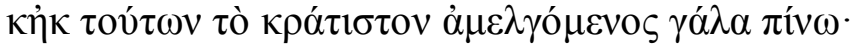

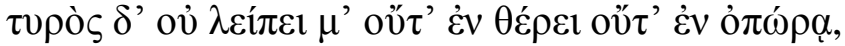

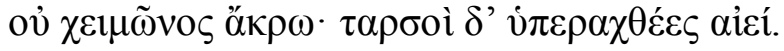

But though I may be such, I pasture a thousand head of cattle, and the milk I drink comes from the best of them. I never run out of cheese, neither in summer nor in autumn, nor even in the middle of the winter. My wicker baskets are always overburdened.

Whereas Euripides had depicted Polyphemus as tired of rustic fare (Cyclops 247), and other authors had given him elaborate cooking instructions or catalogues of food to recite, ${ }^{417}$ the Cyclops' diet in Idyll 11 is very simple. The erasure of Polyphemus' gluttony may have regional overtones: the Cyclops had symbolized the gluttony and luxurious diet long associated with Sicily. Theocritus, however, moderates the tastes of his Sicilian countryman.

But the overarching flaw of the Homeric Cyclops is lack of hospitality, encompassing all the others. Likewise, when Philoxenus associated Polyphemus with Dionysius, this shortcoming probably would have been a main subject, given that the poet had been the tyrant's guest at court before being treated violently and imprisoned. But Theocritus' monster is no longer inhospitable in the eleventh $I d y l l$; instead he issues an entreaty for guests to come visit him on his island.

Polyphemus lists his pastoral riches (cheese and cattle, 34-37) and depicts his cave as an inviting locus amoenus (45-48), as opposed to the nasty sty perhaps depicted by Philoxenus (PMG 818). He begs Galatea to come and forget to leave $(42,63)$. Polyphemus even wishes for a stranger to arrive, so that he might learn to swim (61, in an ironic allusion to Odysseus).

The Cyclops of Idyll 11 also seems to display a measure of intelligence at a variance with the previous literary tradition. This is not the crass, sophistic beast of Euripides and Alexis,

\footnotetext{
${ }^{417}$ See above, note 344.
} 
professing his allegiance to hedonism and money. Quite the contrary: Theocritus draws a strong contrast between Polyphemus' rustic, poetic activity and the expenditure of money (79-80):

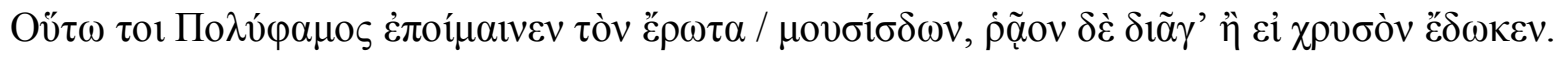
Mark Payne has discussed Polyphemus' self-aware nature, as depicted by Theocritus. ${ }^{418}$ Thus, the Cyclops is aware of his beastly ugliness, but suggests a partial remedy for it (30-33, 50-53), and argues that he can make up in rustic riches what he lacks in physical beauty (34-49). More important, however, is his status as an exemplum. Polyphemus' role in the poem is to demonstrate for Nicias a potential cure for love-longing, and he succeeds, as Theocritus

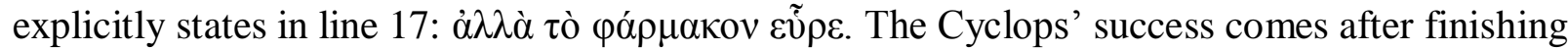
his song, when he chides himself for neglecting his chores and realizes that there are other fish in the sea (72-79):

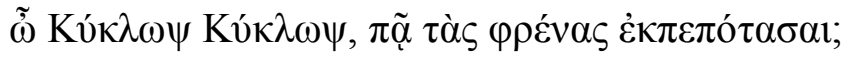

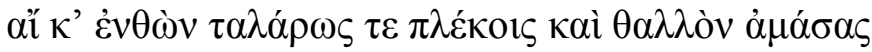

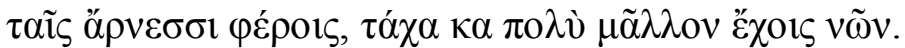

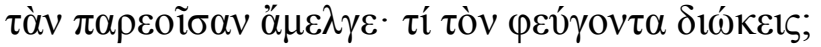

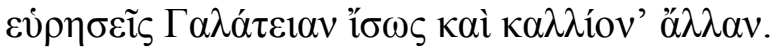

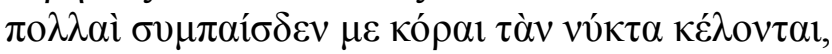

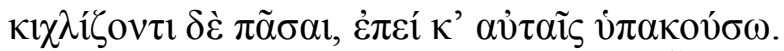

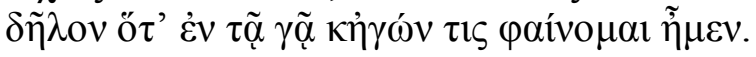

O Cyclops, Cyclops, where have your wits flown? You would have more sense if you went and wove wicker baskets for your cheese and gathered shoots to bring to the lambs. Milk the ewe that's by you. Why do you always chase the one who flees? You might find an even prettier Galatea. Lots of girls call me to play at night, and they all giggle when I answer. It is clear that I too will be somebody in this land.

It is possible to read this passage ironically, as we will discuss momentarily, and claim that Polyphemus is being mocked here. That may be, but an equally attractive reading also exists. ${ }^{419}$ In all previous depictions, Polyphemus has been a glutton and a brute, unable to control his

\footnotetext{
418 Payne (2010) 231.

419 It has been noted that the many competing voices in this and other Idylls may lead to ambiguity and a "breakdown of exemplarity." See Fantuzzi and Hunter (2004) 162-167.
} 
appetites, including sexual ones. But Idyll 11 undercuts this portrait. Polyphemus is no longer violent and gluttonous, and, I suggest, he is no longer the hyper-sexual beast familiar from Euripides, dashing drunkenly off in search of sex. ${ }^{420}$ While it is difficult to say what role Galatea played in previous works, she seems to have been openly hostile to Polyphemus' advances, which were likely as uninhibited and aggressive as all other aspects of Polyphemus' character. ${ }^{421}$ In Idyll 11, however, Polyphemus finds a way of defusing his love, and restrains himself from further pursuit of the quarry that had obsessed him. This Sicilian monster, newly reinvented by a Sicilian poet, is the very picture of moderation. ${ }^{422}$

Even as Theocritus drastically re-characterizes the Cyclops, he alludes at the same time to the more canonical version of the monster. Polyphemus, depicted in this Idyll as a youth (9), refers on several occasions to the Homeric episode, looming ironically in his future, of which he is unaware. He notes that no one (oürı५, 38) among the other Cyclopes plays the syrinx as well as he does, and claims that he really "is somebody" ( $\tau / \varsigma)$ in his own land, in both cases alluding to the well-known "Noman" trick of Odyssey $9 .{ }^{423}$ In line 51, the Cyclops tells Galatea that, if his eyebrow is too shaggy, he keeps a pike made of oak under the ashes of his fire, which she can use to burn his eye, referring to a cosmetic practice of singing away unwanted hair ${ }^{424}$ (51-53):

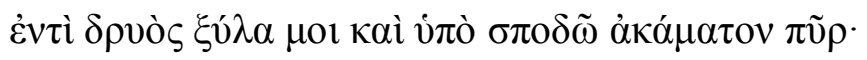

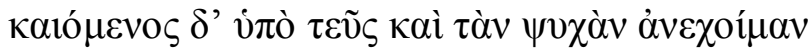

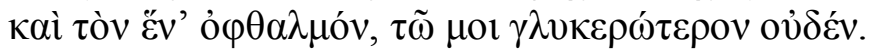

...I have logs of oak and untiring fire underneath the ash. I would endure it even if you scorthced my soul and my one eye, which is sweetest of all to me.

\footnotetext{
${ }^{420}$ Above, 130.

${ }^{421}$ E.g. Philoxenus 818, Nicochares 4, 5 (K.-A.).

${ }^{422}$ For a different interpretation, see Rosen (2007) 165-166 or Hunter (1999) ad 11.77-78. On the difficulty of interpreting Polyphemus' love-life, see Fantuzzi and Hunter (2004) 162, 164-167.

${ }^{423}$ See Hunter (1999) ad loc. in both cases.

424 See Hunter (1999) 237.
} 
The language of these three lines is extremely close to language used in the Homeric Cyclopea.

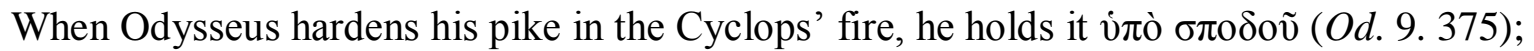

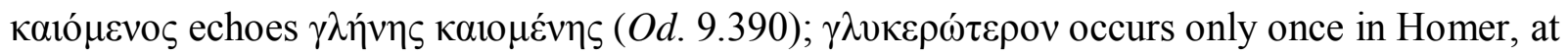
Od. 9.28. ${ }^{425}$ In line 61, Polyphemus wishes that "some stranger would arrive, sailing in a boat," so that he might teach the Cyclops how to swim, an obvious allusion to Odysseus' arrival in the land of the Cyclopes. ${ }^{426}$ Hunter has discussed how Theocritus crafts a "prequel" from such ironic allusions to the Homeric episode, trapping Polyphemus and making him "a pathetic victim of poetic tradition., ${ }^{, 427}$

Hunter's interpretation of Idyll 11 is understandable when considered from a point of view which gives precedence to Homer, fixing the Odyssean narrative unchangeably in place. Two factors, however, militate against a reading that makes Polyphemus the inevitable victim of Homer's narrative. First, there is the authorial sympathy with Polyphemus, including emphasis on their shared heritage, and Theocritus' near total erasure of the negative traits familiar from elsewhere in the tradition, with a corresponding focus instead on Polyphemus' love life and exemplary qualities. Second, there is Idyll 6, which points to some flexibility in the body of stories surrounding Polyphemus, as will be discussed presently. Rather than grimly conceding that his countryman Polyphemus is doomed to "repeat" Homeric history, Theocritus may offer us a vista into a revisionist Cyclopea, in which the monster is not fixedly bound to his previous literary incarnations.

But what of Idyll 6, then, with its additional insight into Theocritus' treatment of the Polyphemus story? There is no better place to begin analyzing Idyll 6 than with Hunter's assessment of it (1999 247):

\footnotetext{
${ }^{425}$ For all these allusions, see Hunter (1999) 237-238

${ }^{426}$ See Hunter (1999) ad loc.

${ }^{427}$ Hunter (1999) 219.
} 
The Cyclops of Idyll 6 responds almost as though $\mathrm{Od} .9$ did not exist: the rarity of verbal echo of that book is remarkable - even when Telemos is explicitly mentioned, it is another book of the Odyssey which is reworked. Whereas the young Cyclops of Idyll 11 exists in a timeless dairy wonderland, the Polyphemos of Idyll 6 swears by Pan and Paian, keeps a pet sheepdog, receives lessons in rustic superstition from an old woman and knows of Parian marble; he is, in short, not unlike the "non-mythical', contemporary characters of the other bucolics. Such 'anachronisms' serve the erasure of $\mathrm{Od} .9$ as a model text... The existence of a famous literary model need not (need it?) determine the poetry of the present; T.'s Cyclops can show bravado in the face of the Homeric pattern, no less than T. himself can demand a place for his bucolic poems in a world which already has Odyssey 9. The fact that Telemos and Homer have spoken does not mean that new directions are not possible.

Hunter draws a contrast between Idylls 11 and 6: in his view, Idyll 11 depicts a character struggling and failing to break free of the literary past, whereas Idyll 6 declares a certain measure of freedom from previous authors. In my view, however, the drastic reimagining of Polyphemus in the Eleventh Idyll should be read closely with Idyll 6, since both reject previous representations of the Cyclops in favor of unexpected variants.

In Idyll 11, Polyphemus serves as a positive exemplum for the poem's addressee, Nicias. The same is true of Idyll 6, where the behavior of the Cyclops is held up as one of several paradigms for the addressee, Aratus. It is difficult to say, however, exactly what message the Sixth Idyll means to convey. ${ }^{428}$ The poem begins by describing, in a frame narrative, the setting of a friendly singing contest between two herders, Daphnis and Damoetas (1-5), and ends with a description of their mutual admiration and affection (42-46). The friendship of the herders, based around artistic exchange, is an appropriate emblem of the exchange of epistolary poems between Theocritus and Aratus, and this accounts for part of the exemplary tone of Idyll 6.

The internal narrative about Galatea and Polyphemus also acts as a paradigm. The body of the poem consists of a song exchange, with Daphnis singing first, Damoetas second. Daphnis'

${ }^{428}$ On the difficulty of interpreting exempla in the Idylls see Fantuzzi and Hunter (2004) 162-167. See also Hunter (1999) 243-244. 
song is addressed to Polyphemus and is about Galatea. But Daphnis composes his song in the third person — he does not himself impersonate Galatea. Damoetas, however, responds to Daphnis in the first person, speaking as if he were Polyphemus. Thus, Polyphemus' song once again approximates the authorial voice, eliciting the sympathies of the addressee and the audience. $^{429}$

Literary tradition has conditioned the reader to expect that Polyphemus be stupid, and that expectation shapes the tone of Daphnis' song. The speaker of Daphnis' song, an unidentified third party, chides Polyphemus about his behavior toward Galatea. The speaker thinks he has the upper hand on the Cyclops, informing the ogre about matters of which he is supposedly unaware. He claims that Polyphemus does not see $(\pi \circ \theta$ ó $\rho \sigma \theta \alpha, 8)$ that Galatea is flirting with him by throwing apples at his flock, and calls him a sorry wretch ( $\tau \alpha \dot{\lambda} \alpha \nu \tau \tau \alpha \dot{\lambda} \alpha \nu, 8)$. Apparently in agreement with Galatea that Polyphemus is helpless in matters of love ( $\delta v \sigma \varepsilon ́ \rho \omega \tau \alpha, 7)$, the speaker of Daphnis' song offers the Cyclops some advice: Galatea will only flirt from a distance

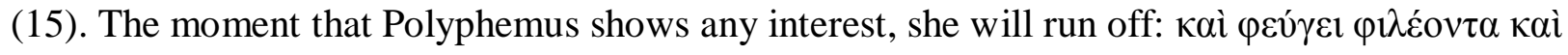

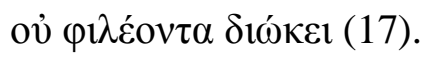

The speaker of Daphnis' song assumes he knows something that Polyphemus does not,

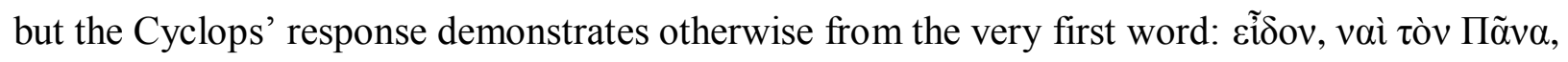

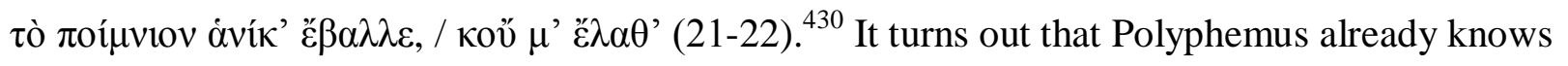
what his interlocutor had wanted to tell him, namely, that women chase the one who flees, and flee the one who chases. It was for exactly this reason, in fact, that the Cyclops was ignoring Galatea (25-28):

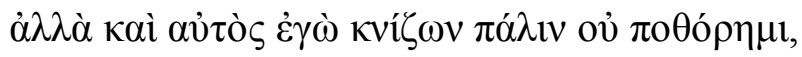

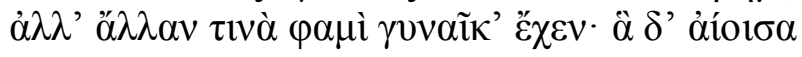

\footnotetext{
${ }^{429}$ For this technique in Idyll 11, see Rosen (2007) 161.

${ }^{430}$ On the point-by-point responsion between the songs of Daphnis and Damoetas, see Cusset (2011) 47-49.
} 


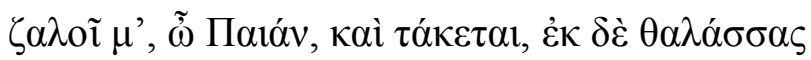

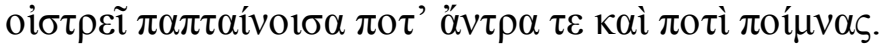

But I'm the one who's teasing her, since I never look her way, but I tell her I already have a wife. And when she hears that, O Paian, she gets jealous and longs for me, and she goes mad as she peeps from the sea at my cave and at my flocks.

Polyphemus is purposefully goading Galatea, saying he has already got a wife, hoping to inspire jealously in the nymph. And whereas the first speaker had thought Polyphemus was unaware that his dog was threatening Galatea (9-14), he is off the mark again. The Cyclops has set his dog on the Galatea in order to get a reaction out of the nymph, since, when the dog was sitting quietly, Galatea had no interest in him (29-30). But Polyphemus is no sucker—even if Galatea shows a little interest and sends him a message (31-32), he is not going to open his cave to the nymph until she has sworn to make their wedding bed on his island (32-33). ${ }^{431}$

Whereas literary tradition and the narrator of Daphnis' song set up the audience to expect the Cyclops to be a dolt, Polyphemus proves to be unexpectedly cunning, and gets the better of our expectations. Theocritus has therefore drawn a sharp distinction between his poem and previous incarnations of the Polyphemus. As Hunter notes in the passage quoted above, ${ }^{432}$ Idyll 6 seems to exist on a very different plain from the Homeric Cyclopea, or, for that matter, any previous Cyclopea. Just as in Idyll 11, the Cyclops' character is being rehabilitated - the negative traits that we had come to expect from the Sicilian monster are being erased or reversed.

This reimagining of the Cyclops by the poet continues in the last part of Polyphemus' song, when he describes his own physical features. He had already discussed his features in a self-aware fashion in Idyll 11 (30-33, 50-53) ${ }^{433}$ But now the Cyclops insists that he is, in fact, beautiful, contrary to whatever rumors "they" have been spreading:

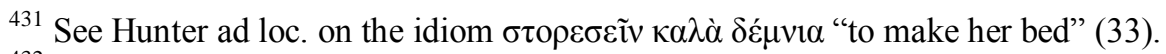

${ }^{432}$ (1999) 243; see above, 155-156.

${ }^{433}$ Above, 152.
} 


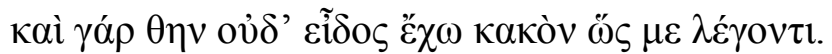

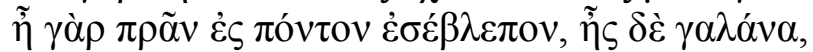

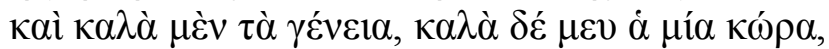

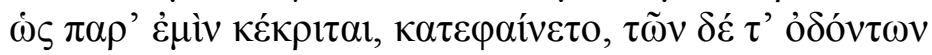

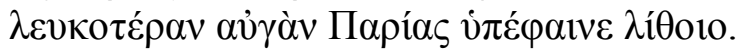

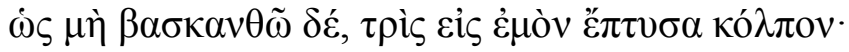

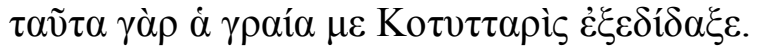

And really, I haven't got bad looks, like everybody says. Just recently I looked into the sea, when it was calm, and my beard was beautiful in the reflection, and my one eye was beautiful, at least if I'm the judge, and the gleam of my teeth was whiter than Parian marble. To block the evil I, I spat on my breast three times, for that's what the old woman Cottytaris taught me.

As Hunter notes ${ }^{434}$ this passage, with its repetition of $\kappa \alpha \lambda \grave{\alpha}$, is a direct rejoinder and reinterpretation of "Daphnis" final line (18), in which he warns Polyphemus that looks can be

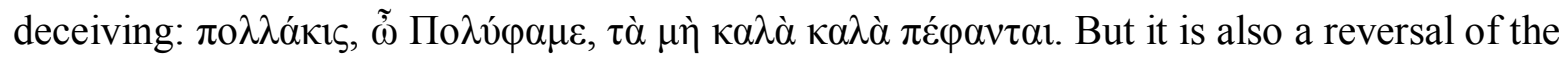
larger literary tradition, which took it for granted that Polyphemus was monstrously ugly. Here Polyphemus is given the chance to speak for himself. And when he does so, it is in a markedly "Sicilian" manner. Recognizing that it is not good luck to speak so favorably of his own appearance (just as in Idyll 11, this Cyclops is peculiarly self-aware), Polyphemus makes use of a rustic superstition that understands spitting to be apotropaic. ${ }^{435} \mathrm{He}$ learned this method of warding off bad luck from the hag Kotytarris, whose name is derived from that of "a Thracian goddess whose cult had spread throughout the Greek world, especially to Corinth and Sicily." Thus, Polyphemus seems to partake of the habits of a contemporary Sicilian rustic. ${ }^{437}$ Idyll 6 departs most strikingly from previous literary tradition in its approach to Galatea. As far as we can tell, previous poetic sources that treat Polyphemus' love for Galatea make the nymph's rejection of the Cyclops a forgone conclusion. There is strong evidence of Galatea's

\footnotetext{
${ }^{434}$ (1999) 257. See also Cusset (2011) 47-49.

${ }^{435}$ Hunter (1999) 239.

${ }^{436}$ Hunter (1999) 239.

${ }^{437}$ Cf. Christoforidou (2005) 35-38.
} 
hostile attitude in Philoxenus and Nicochares (Philoxenus $P M G$ 818; Nicochares fr. 4 K.-A.), and Alexis' generally negative portrait of Polyphemus in his Galatea, as seen in fr. 36 K.-A. suggests that the nymph rejected the Cyclops in that play, as well. ${ }^{438}$ Even in Idyll 11, where it is Polyphemus' own resolve that allows him to turn from his interest in Galatea to more pressing pastoral chores, he apparently is not successful in wooing his quarry. But Idyll 6 is different. Here Polyphemus does not compose a love song, a central feature of previous versions. He changes his tactic and sits quietly on the shore. The Cyclops' transformation from stupid, ugly, violent monster to an attitude of aloof cunning is a drastic change, and even more strikingly, Theocritus leaves open the possibility that such a strategy may succede. In Idyll 6, as opposed to previous treatments, it is Galatea who pursues Polyphemus, not the other way around. Daphnis' song sets up the reader to expect that the Cyclops does not notice the nymph's attention, and even ironically suggests that Galatea's flirting may not be as sincere as it appears. Yet Polyphemus' song constitutes a direct rebuttal to Daphnis' insinuations — not only is he aware that Galatea is flirting with him, but his seeming ignorance is all part of a cunning plan to seduce Galatea. Polyphemus acknowledges and rebuts Daphnis' sly suggestion in line 19 that Galatea's intentions may be ironic by turning the point on its head. Things are not always what they seem, claims Polyphemus in verses 34-40. But he is not referring to the affections of Galatea, but to his own looks: he is more beautiful than people say. ${ }^{439}$

The strength of the Cyclops' response to the first song leaves open the possibility that his fate will be different from that of the Polyphemus readers had already encountered in Philoxenus and elsewhere: he may just get the girl. ${ }^{440}$ The way that Idyll 6 ends, with Daphnis and

\footnotetext{
${ }^{438}$ See above, note 344 and page 150.

439 Above, 152.

${ }^{440}$ Cf. Hunter (1999) 247, who discusses the Cyclops ability to break free of the Homeric past, and see pages $155-$ 156 above.
} 
Damoetas embracing, trading gifts, and both unbeaten ( $\dot{v} v \dot{\sigma} \sigma \sigma \alpha \tau o$, 46) suggests that the songs of each singer are to be taken seriously; if both songs are victorious, then neither perspective can stake a claim on the "correct" version of the Cyclops narrative. Considered together with the drastic reform of Polyphemus' character undertaken by Idyll 11 and 6, even the possibility of the monster's romantic success is a drastic revision to the literary tradition. ${ }^{441}$

Despite the obvious comedic intentions of Idylls 11 and 6, there are indications that this revisionist elaboration of the Cyclopea and the monster's love for Galatea should be read as a comment about Sicilian identity. Theocritus is the first poet we know of to allow for the possibility that Polyphemus actually gets the girl, but he may be tapping into previously existing Sicilian tradition. The Sicilian historian Timaeus (c. 350-260 BC, thus an older contemporary of Theocritus) $)^{442}$ reports that Polyphemus and Galatea had had a child together called Galetes, after

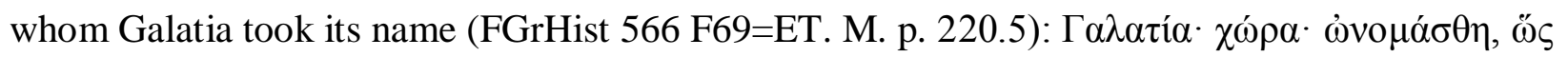

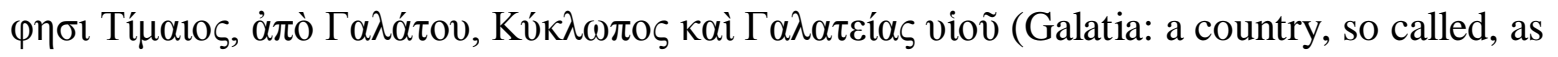
Timaeus says, after Galetes, the son of the Cyclops and Galatea). Several scholars have even suggested that the legend of Galatea and Polyphemus having children began as propaganda in the court of Dionysius I, to help justify his expansion in the Adriatic. ${ }^{443}$ Whether speculation that this story was linked to the court of Dionysius is true or not, the tradition that Polyphemus was successful in his attempts to woo Galatea was not a one-off suggestion by Timaeus. In the years following Theocritus, the romance of Galatea and Polyphemus became a popular theme in the visual arts, and there were depictions of both versions of the story: sometimes Galatea appears to

\footnotetext{
${ }^{441}$ Cf. Fantuzzi and Hunter (2004) 162-167.

442 See Meister's article in Brill's New Pauly, s.v. "Timaeus [2]." See also Baron (2012) 18.

${ }^{443}$ Braccesi (1994) 94; Caven (1990) 153. The Timaean tradition is elaborated in Appian, 3.2, where Polyphemus and Galatea have three sons, Celtus, Illyrius, and Galas, who leave Sicily and lend their names to three eponymous regions. See also Baron (2012) 134, who thinks that Timaeus himself might have been the first one to link Polyphemus with the region of Galatia.
} 
be rejecting Polyphemus, but sometimes she is obviously accepting his approaches, even embracing him. ${ }^{444}$ Whether these artists are following Theocritus or another variant on the Galatea myth, it is clear that a story of a successful liaison between the monster and the nymph continued to be in circulation throughout the Hellenistic era and into the Empire.

Theocritus leaves room for this variant in his composition of Idyll 6, where Polyphemus' seduction of Galatea is one possible outcome. In leaving open this possibility, Theocritus is challenging and overturning a tradition perpetuated by non-Sicilian poets, such as Philoxenus and Nicochares, that Polyphemus did not get the girl—a tradition in line with the typical depiction of the Cyclops as ugly, stupid, violent and generally inhospitable. Theocritus invites the reader to interpret these conspicuous reversals in light of regional identity, by citing Sicily as the shared place of origin of both the monster and himself (Id. 11.7). Now, in Idyll 6, having erased or reversed the most negative aspects of the Homeric as well as $5^{\text {th }}$ - and $4^{\text {th }}$-century Cyclops stories, mostly composed by non-Sicilian poets for non-Sicilian audiences, he sides with the Sicilian historian Timaeus in suggesting that Polyphemus' erotic cunning worked, and that he ended up with Galatea after all.

\section{THE ROMANCE OF POLYPHEMUS AND GALATEA: A SICILIAN ORAL TRADITION?}

The possibility that Idyll 6 incorporates a local, Sicilian version of the Polyphemus and Galatea romance, in which the two end up together and have children, raises the question of the nature of such a local tradition. First, there is the question of origins: is the romance of Polyphemus and Galatea an invention of Philoxenus, where it makes its first appearance, or might the tale have non-literary origins? How, if at all, does Galatea relate to the Homeric

\footnotetext{
${ }^{444}$ Touchefeu-Meynier in LIMC VIII.1 1016-1018.
} 
Cyclopea? Does the romance has any special significance for Sicily? The final part of this chapter will be devoted to addressing these questions.

The ancients had their own theories about the introduction of Galatea into the literary tradition. We have already discussed Phaenias' claim that Philoxenus drew the character of Galatea from real life: she was supposedly a concubine of Dionysius' I, whom the poet seduced, ending up as a prisoner in the quarries as a result. In retribution for his harsh treatment at the hands of the Syracusan tyrant, the poet composed a satirical and allegorical account of the whole affair in his dithyramb Cyclops, in which the Cyclops stood for Dionysius, Odysseus for Philoxenus, and Galatea for Galatea. Whether this story is true, partly true, or entirely false, it was nonetheless incorporated into a hostile tradition against Dionysius. ${ }^{445}$ It is not possible to know most of what Philoxenus wrote. Nor should we accept the allegorical-biographical account of Phaenias at face value. Nonetheless, we can gather from Phaenias that Polyphemus, Odysseus, and Galatea appeared in the poem, and that the dithyramb likely included some satire that gave rise to the allegorical interpretation. ${ }^{446}$ Further, it is significant that Philoxenus, the author who introduces Galatea into the literary tradition, worked at the Syracusan court, linking the first literary treatment of the Polyphemus and Galatea romance to Sicily.

The other ancient theory of Galatea's origin also links the story to Sicily. Douris, a slightly older contemporary of Theocritus (c. 340-270 BC), reports that Galatea was a Sicilian nymph with a local cult:

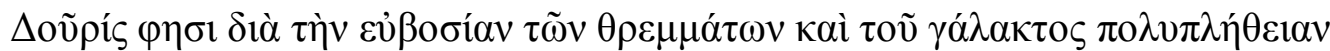

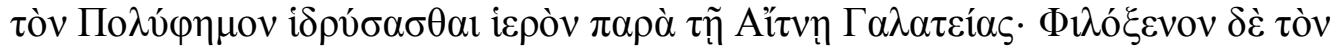

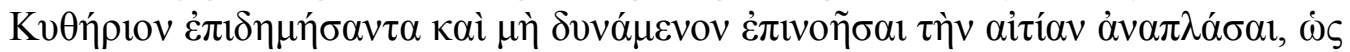

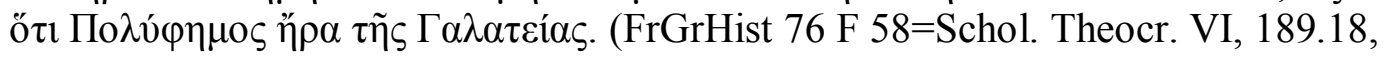
Wendel)

\footnotetext{
${ }^{445}$ Above, 134-143.

${ }^{446}$ See above, pages 134-143 and Hordern (1999) 448.
} 
Douris says that Polyphemus built a shrine to Galatea near Mount Etna on account of the richness of the pastures, and the abundance of milk; but that when Philoxenus of Cythera visited and could not think of the reason, he invented the story that Polyphemus had been in love with Galatea. (trans. Hordern 1999)

If it seems strange that a Cyclops would love or institute the worship of a nymph, it is useful to remember that Polyphemus was the son of the sea-nymph Thoosa and Poseidon, god of the sea (Od. 1.71). Perhaps more significant, Polyphemus is an unabashed milk-drinker and cheese-eater (Od. 9.219-250). The name of the nymph, therefore, with its similarity to the word $\gamma \alpha \dot{\alpha} \lambda \alpha$, may have suggested her as a convenient companion to the Cyclops. Nonetheless, we need not believe everything that Douris tells us. For instance, it is not likely, we may presume, that a one-eyed monster named Polyphemus actually founded a cult to Galatea. Yet the anecdote may well reflect actual Sicilian stories and traditions related to the cult of a nymph. It is worth noting, for instance, that Douris' description of a friendly and loving Cyclops is very much at odds with other depictions prior to Theocritus, which may point to a body of tales independent from the literary traditions with which we are familiar.

In addition to the Douris fragment, there is further evidence that the tradition making Sicily the home of Polyphemus was not merely literary, but deeply embedded even in the landscape of the island. Pliny (NH 3.8.89) mentions the rocks of the Cyclopes and the harbor of Ulysses off the Sicilian coast (scopuli tres Cyclopum, portus Ulixis). Servius (ad Aen. 1.201) makes a similar claim (CYCLOPEA SAXA aut quae Cyclops in Ulixen iecit, aut certe Siciliam dicit, quae plurimis locis saxosa promunturia habet, in qua Cyclopes habitaverunt), and mentions the region of Aetna or Catania in particular. ${ }^{447}$

\footnotetext{
${ }^{447}$ See also Callimachus (Hymn to Artemis 46-47), who locates the workshop of the Cyclopes on Lipara, off the north coast of Sicily. And at least as early as Euripides, of course, the Cyclopes had been located specifically at Aetna (Cyclops 20-21).
} 
Oral-traditional stories drawing on the Cyclops narrative persisted on Sicily until the modern day. A story called "The Little Monk," collected in Erice, in the north-western corner of Sicily, and originally published in 1875 , is very clearly an example of The Ogre Blinded, though the monster in this case has two eyes. ${ }^{448}$ Two monks get tired while travelling, and decide to take a rest in a cave. Lo and behold, the devil is inside, killing sheep and cooking them over a fire. He forces the two monks to eat. The monks go to sleep, but the devil gets up and plugs the entrance to the cave with a stone. The devil takes a poker, skewers the older monk through the neck, cooks him and eats him. The monster forces the remaining monk to eat, but he only pretends to do so. That night, the monk heats up the iron and blinds the devil with it. He escapes in the wool of a sheep. This tale shows that stories about the Cyclops could easily have been in circulation on ancient Sicily. While "The Little Monk" may originate, ultimately, from Homer (though this is by no means certain), it has achieved a large degree of independence from the literary tradition. The teller obviously did not connect it with the Homeric version, since the details are modified in a way quite alien to the Odyssey narrative. Another modern tale from Cianciana, near the south coast of Sicily, almost due south of Palermo, is entitled "The Cyclops," ${ }^{449}$ but does not resemble The Ogre Blinded in structure. It is suggestive, nonetheless, of the persistence of the Cyclops in Sicilian folklore that this modern tale includes a number of one-eyed Cyclopes as characters.

As discussed already in Chapter 1, nymphs were also of great cultural importance to Sicily. While nymphs are a common feature of Ancient Greek lore in general, Jennifer Larson has discussed their special importance to the island of Sicily. ${ }^{450}$ In most locations, the nymphs are relegated to the status of generic local deities. In Thessaly and Sicily, however, river gods and nymphs were prominently featured on state coins. It was Sicily that first incorporated

\footnotetext{
448 Pitrè (2009) No. 51.

449 Pitrè 2009, No. 71. Original publication in 1875.

450 (2001) 211.
} 
nymphs into public iconography; Thessaly then followed Sicily's example. ${ }^{451}$ While nymphs had always been part of Greek religious thought, they take on a new significance in Sicily and the western colonies. Images of river gods and nymphs imprinted on coins allowed the settlers to recontextualize the landscape as Greek and to proclaim the fertility of their colony to the rest of the Hellenized world. ${ }^{452}$ At Syracuse, the state sacrificed bulls by drowning them in the pool of the nymph Kyane, sacred to Kore. ${ }^{453}$ Timaeus attests to a more popular ritual, a night-long festival including house-to-house offerings to the nymphs and drinking before their statues. ${ }^{454} \mathrm{~A}$ cult to the nymphs dating back to the archaic period was located near the theater in Syracuse, and a nymphaion discovered there dates to the $3^{\text {rd }}$ century BC. Also found in Syracuse is a $4^{\text {th }}$ century $\mathrm{BC}$ inscription to Apollo and the nymphs, while a cave that hosted banquets to the nymphs was located near the city. ${ }^{455}$

The testimony of Douris should be considered in this context. Douris claims that Polyphemus built a shrine to Galatea near Mount Aetna on account of the richness of the pastures, and the abundance of milk; but that when Philoxenus of Cythera visited and could not think of the reason, he invented the story that Polyphemus had been in love with Galatea. The cult of Galatea is apparently concerned with fertility. Nymphs are associated with fertility more generally, but the connection of nymphs to fertility was an especially important aspect of Sicilian ideology, as mentioned above. ${ }^{456}$ Even if we should not trust that Polyphemus himself was responsible for founding the cult to Galatea, the description of its purpose is nonetheless akin to what we would expect from a Sicilian cult of the nymphs. The location of the cult, as reported by

\footnotetext{
${ }^{451}$ Larson (2001) 211.

${ }^{452}$ Larson 2001 211-212. See also above, 23, 59-60.

${ }^{453}$ Diodorus 5.4.2 and Larson (2001) 214.

454 Timaeus 566 F 32 = Athen. 6.56; Larson (2001) 215.

${ }^{455}$ Larson (2001) 216.

456 Above, 23, 59-60; Larson (2001) 109, 212.
} 
Douris, is the region of Aetna, a location that fits in well with other testimony about the Cyclops and Galatea, both in Euripides (e.g. Cyc. 20-21) and Theocritus. At Idyll 11.47, in his attempts to persuade Galatea to join him in his cave, Polyphemus boasts of the cool water which Aetna provides for him. It is plausible, therefore, not only that a cult to Galatea, relating to Polyphemus in some way, may have existed at Aetna, but also that Philoxenus may have drawn upon local, Sicilian stories about the romance of Galatea and Polyphemus associated with such a cult. ${ }^{457}$

Indeed, there is some indication from Hermesianax that Philoxenus played up Galatea's role as a fertility goddess in his dithyramb $(P M G 815=$ Hermesianax ap. Athen. $13.598=$ Powell fr. 1.69-74):

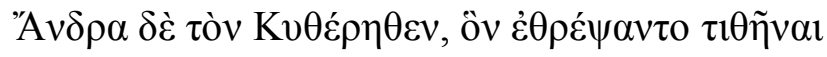

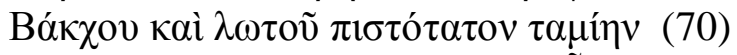

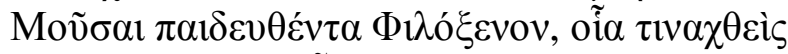

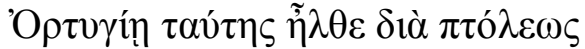

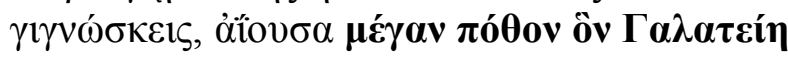

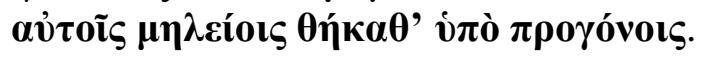

And him of Cythera, most faithful squire Of Bacchus and the flute, nurtured and reared By Muses for his nurses-how, distressed In Ortygia he travelled through this city, You know, and that great love which Galatea Inspired into the very first-born lambs. (Trans. Lightfoot)

Since nymphs are commonly associated with fertility in Sicily, and since Philoxenus seems to have highlighted Galatea's role as a fertility goddess in his dithyramb, it increases the likelihood that local Sicilian traditions were influencing his Cyclops.

In sum, while the earliest literary witness to the romance of Polyphemus and Galatea is Philoxenus, there is reason to believe that the poet, who had spent time in Syracuse, may have been drawing on local Sicilian traditions. The fragment of Douris suggests that there was a cult

\footnotetext{
${ }^{457}$ Larson also argues for the existence of a cult to Galatea in the region of Aetna on the basis of the Douris fragment, (2001) 217-218.
} 
to Galatea on Sicily, and that stories about Polyphemus were associated with it. The cult mentioned by Douris is part of a larger array of evidence suggesting that both Cyclopes and Nymphs figured prominently in the non-literary culture of Sicily, associated with features of local landscape, art and cult.

However, it remains to investigate how the Homeric Cyclopea is related to stories of Galatea and Polyphemus. As discussed above, ${ }^{458}$ the Polyphemus episode of Odyssey 9 is an example of the international, oral-traditional tale-type, The Ogre Blinded. ${ }^{459}$ Yet there is no hint of Galatea in that story. How is it that Galatea came to be a character in the Cyclopea? Since both the Nymph and the Cyclops are important to Sicily, one answer may lie in simple proximity: stories were told about both figures on the island, and, eventually, their stories were combined. But there is evidence of a deeper connection between the Cyclops and Galatea, with its roots in The Ogre Blinded story itself. Just as Homer's narration of the encounter between Polyphemus and Odysseus is a particular variant on a widely-told tale, so the romance of Polyphemus and Galatea may have its basis in a small subset of Ogre Blinded tales, which introduce a female character in addition to the hero and the monster.

Classicist and folklorist Graham Anderson has discussed an Armenian folktale in which a young prince encounters a one-eyed monster named Tepegoez. ${ }^{460}$ The monster is holding a princess hostage. She tells the prince that he will be able to escape the monster only by burning out his eye with a hot poker. He does so, takes the princess back to her father, and the two get married. Based upon the evidence of this Armenian tale, Anderson has speculated "it may be that the Cyclops' princess has dropped out of the Cyclops tale when it was refashioned to fit its place

\footnotetext{
${ }^{458}$ Above, 122-124.

459 Aarne-Thompson tale-type 1137.

${ }^{460}$ Anderson (2006) 81.
} 
in the Odyssey." ${ }^{461}$ Perhaps the poet of the Odyssey made a conscious decision to exclude a princess or some other love interest from his telling, since a female companion would not be consistent with Homer's emphasis on the ogre's isolation and backwardness. Regardless of whether Homer was aware of such a variant, however, there appears to have been a version of the story in circulation that included a princess.

Stories of this sort have been collected in a number of different locations, including modern Greece. James Frazer records a story from Lasta in Gortynia, Arcadia, about a traveler who ends up in a land of one-eyed giants. ${ }^{462}$ The traveler stays at the house of one of the giants. The wife of the giant hides the traveler when her husband is away from the cave during the day. When the ogre arrives home, he thinks he smells a man, and looks around his house. The ogre finds the man, however, and is about to eat him, going so far as to stick the unlucky traveler in his mouth. But the giant relents at his wife's behest. The next day, the giant tries again to eat the man, but the monster's wife gets him drunk. She urges the man to flee, but before escaping he burns out the drunken giant's eye with a coal. The giant never again attempts to eat a man. Clearly, this story is not a simple analogue of the Polyphemus-Galatea romance as we know it from Philoxenus or Theocritus. But such a variant may have provided the raw materials for cult stories like that reported by Douris, or literary adaptations like that of Philoxenus. A version of the tale in which Polyphemus had taken Galatea as a wife certainly seems to be behind the tradition reported by Timaeus, according to which the two have children. Tale 26 of Frazer's appendix is, at the very least, proof that some variants of The Ogre Blinded exist in which the monster has a wife.

\footnotetext{
461 Anderson (2006) 81; See also Anderson (2000) 124, where he discusses the possibility that there may have been a larger variety of ancient variants of the Polyphemus story than we are aware.

${ }^{462}$ Frazer's Apollodorus (1989), vol. ii. 441. Appendix XIII, Ulysses and Polyphemus, Story 26.
} 
The Cyclops also has a wife in tale 20 of Frazer's appendix, recorded in Brittany (432433). Here, though, the wife is also an ogre, who tries and fails to assist her husband in eating the hero. In other regards, however, the story has striking similarities to the Odyssey narrative. The hero, named Bihanic, is sent by a king to rob a Cyclops of several magical items, including a prophetic parrot. (Prophecy is also part of the Polyphemus story, in the figure of Telemus). The giant has a herd of sheep and a shepherd to watch over them, reminiscent of the Cyclops' pastoral traits in the Homeric story. Bihanic skins one of the sheep and disguises himself in the animal's hide, but he does so to sneak into the ogre's castle, while Odysseus had hidden under a ram to sneak out of Polyphemus' lair. The prophetic parrot informs the giant of Bihanic's presence, the ogre discovers him, and delivers him to his wife, a giantess, to be cooked. The hero tricks the giantess by flattery, saying how fair she is, and then takes a hatchet to her skull and escapes with the magic items he had come for. The comical emphasis on the looks of the giantess might remind us of Polyphemus' description of his own features in Idylls 11 and 6.

Another example is story 24 of Hackman's collection of Ogre Blinded Tales, Die Polyphemsage in der Volksüberlieferung, from Argyllshire. ${ }^{463}$ Machkan-an-Athar, the son of a king, was lying by the shore, when a one-eyed giant approached, drawing a ship behind him with one hand, fishing with the other. He was fishing for dead bodies, since there had been a war. The giant tries to fish-up Machkan-an-Athar, but fails, so he just grabs the man. The ogre takes the cadavers back to his cave, at the entrance of which stands his beautiful wife. He gives his wife the cadavers and says he will eat them for breakfast; then he goes to bed. At the suggestion of the giant's wife, who is an abducted princess, Machkan-an-Athar heats up a skewer and blinds the ogre. The Cyclops makes a clamor and searches for his opponent, but cannot find him. He hurls the rock from the door into the ocean, thinking that the man had escaped. He runs to the door,

\footnotetext{
${ }^{463}$ Hackman (1904) 29-30.
} 
and slams the skewer against the post, breaking his head. ${ }^{464}$ This tale clearly resembles the Homeric version in its basic narrative and many of its particulars, with the addition, however, of a female character. One detail may be important that is not provided by Hackman, but which does appear in the original. ${ }^{465}$ Once the Ogre falls asleep, his wife reveals to the hero that, although they sleep together, the Cyclops has not yet touched his wife. The monster will not dare to consummate his marriage until the end of a seven year period, which will be over in two days. $^{466}$ The presence of a female character - the love interest of the one-eyed ogre-is very suggestive in itself. It is easy to see how this bare-bones narrative about the giant, his wife, and a mortal interloper, might give rise to a story about the Cyclops' inept attempts at courting his beloved. However, the additional detail here of the monster's long wait before the consummation of his love suggests a kinship with Philoxenus' version, in which Polyphemus longs for Galatea, but does not obtain her. ${ }^{467}$

Another version of the tale, found, with minor variation, both in Russia and Belorussia is important for introducing a medical motif. ${ }^{468}$ Burma, the stepson of the Tsar, must retrieve some royal insignia from a far-off kingdom, whose ruler has died. He causes the daughter of this dead ruler to fall in love with him, and makes off with their treasure. He arrives at the house of the one-eyed Schkuropet, who happens to be the uncle of the princess the hero has abducted. Burma tells the monster that he is a doctor, and says he can heal his eye. Burma ties down the Cyclops,

\footnotetext{
464 The preceding account is closely paraphrased from Hackman.

465 MacInnes (1890) 263-267.

466 MacInnes (1890) 265.

${ }^{467}$ In a similar variant from Satakunta, Finland (Hackman No. 84, pp. 76-7), a one-eyed mountain-spirit had abducted three princesses. A young farmhand decides to free them, and blinds the Cyclops with a heated ovenprong. The mountain-spirit tries to find the boy, but cannot. The farmhand cuts off his head. Here again, we have only the most basic outline of a story, but it is not difficult to imagine that such an account could be the basis of a longer and more detailed tale, whether as an oral or literary narrative.

${ }^{468}$ Hackman no. 60, pp. 58-59 and no. 76, pp. 70-71.
} 
and blinds him by pouring pitch in his eye. Burma goes on to escape beneath a ram, much as Odysseus. ${ }^{469}$

The trick employed here by Burma—posing as a doctor and pretending to heal the Cyclops' eye, but blinding him instead — is a common one among the collections of known Polyphemus-tales and may be lurking under the surface of Homer's narration of the Cyclopea; ${ }^{470}$ moreover, it may have particular relevance to Classical and Hellenistic literary treatments of the Cyclops, especially that of Theocritus. The beginning of Idyll 11 is famously addressed to

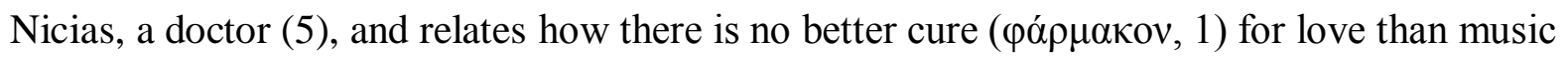
(Theocritus 11.1-8). Philoxenus had already claimed that the Cyclops tried to cure his love for Galatea with the aid of the Muses (Philoxenus PMG 822; Plutarch Quast. Conviv. 1.5.1): tòv

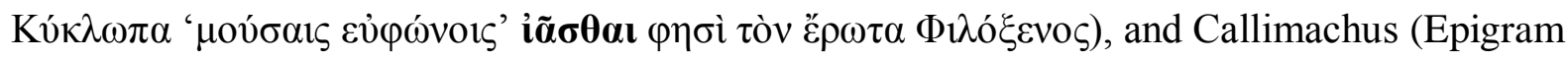

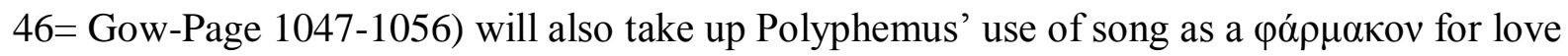
(4). In at least one version, reported by Synesius but which may go back ultimately to Philoxenus

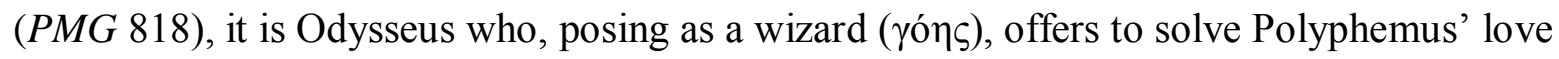

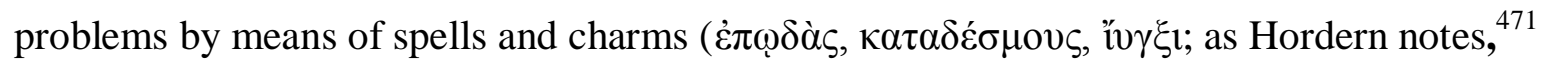

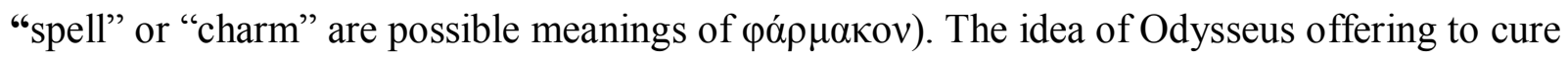
the monster of his love-sickness may be an extension of the folkloric trope according to which the trickster-hero escapes by offering to cure the ogre of an eye-disease, or perhaps even a variant folk-story in which this shift to love-sickness rather than eye-sickness had already taken place. When Odysseus disappears from literary treatments of the Cyclopea in the years following

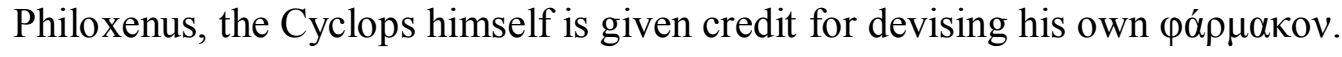

\footnotetext{
${ }^{469}$ Closely paraphrased from Hackman.

${ }^{470}$ Hansen (2002) 296; Austin (1983) 14 with n. 10.

471 (2004) 289.
} 
None of these tales offers a perfect analogue to the romance of Polyphemus and Galatea as we find it in Philoxenus or Theocritus. However, these examples do demonstrate that a female character, who is the wife or love-interest of the ogre, is easily integrated into versions of the Cyclopea that otherwise closely resemble the Homeric episode. Some of these stories, moreover, include elements that echo Hellenistic Greek variants of the tale, especially the occasional emphasis on the ogre's need for a cure for eye-disease, which may anticipate the emphasis on a cure for love-sickness found in Philoxenus, Theocritus, and Callimachus. ${ }^{472}$

Since nymphs and the Cyclops were important elements of local Sicilian culture, the romance of Polyphemus and Galatea most likely originated in a Sicilian version of The Ogre Blinded, in which the monster had a love interest or wife, which used the names of mythical figures of local importance (Polyphemus and Galatea). Such a story may have been the ultimate source of cult stories like the one Douris preserves ${ }^{473}$ and of the romance of Polyphemus and Galatea, first introduced into the literary tradition by Philoxenus, a poet with ties to the Syracusan court.

\section{CONCLUSION:}

\section{THE MEANING OF THEOCRITUS' CYCLOPS TO SICILY AND THE GREEK WEST}

This chapter concludes by exploring the colonial associations of the Cyclops story in Sicily and the Greek West. After the Odyssey, the earliest extant mention of the Cyclops in Greek literature is from the Cyclops of Epicharmus, active in Syracuse during the 480s and 470s. ${ }^{474}$ But Homeric tales, including stories of the Cyclops, circulated in the Greek West long before Epicharmus. The well-known "Cup of Nestor," which makes self-conscious literary

\footnotetext{
${ }^{472}$ On which see Hordern (2004).

${ }^{473}$ FrGrHist 76 F 58=Schol. Theocr. VI, 189.18, Wendel.

${ }^{474}$ Olson (2007) 409-410.
} 
allusions to Homeric poetry, was buried with an adolescent Euboean colonist on Pithekoussai around $720 \mathrm{BC},{ }^{475}$ and the Cyclops was the first Homeric character to be depicted on Greek vases, first appearing between 670 and $650 .{ }^{476}$ Perhaps the most interesting example from this period is the Aristonothos Crater, crafted by the eponymous West Greek artist for the Etruscans in the first half of the $7^{\text {th }}$ century. ${ }^{477}$ The vase shows a naval-battle on one side, and the blinding of Polyphemus on the other. Vase paintings are not the only indication that the Etruscans were familiar with Odysseus from an early date. By the $5^{\text {th }}$ century, Etruscan inscriptions refer to Odysseus in a native transliteration of the name adopted from Euboean colonists at an early date, and the hero appears to have received cult at the Etruscan town of Cortona. ${ }^{478}$ Both the Euboeans who settled in Pithekoussai, then, and the Etruscans with whom they came into contact were probably familiar with the Cyclopea, perhaps even in its Homeric form.

Like the Euboeans of Pithekoussai, the Etruscans were expanding and colonizing in the first half of the $7^{\text {th }}$ century, and Malkin suggests that this shared experience may account for their joint interest in Odysseus' wanderings. ${ }^{479}$ The colonial experience is the explicit frame of the Polyphemus episode in Odyssey 9. Homer describes an empty, wild island adjacent to the land of the Cyclopes that would be ideal for colonization: it is fertile, full of wild goats, and contains a good harbor, but the Cyclopes do not have boats to cross the narrow stretch of water and settle it

\footnotetext{
${ }^{475}$ Malkin (1998) 156-160.

${ }^{476}$ Malkin (1998) 41; Touchefeu-Meynier LIMC VII.1 1013-1014.

${ }^{477}$ Malkin (1998) 166. The Aristonothos Crater is figure 282 in Boardman (1998), with discussion on page 114; see $16^{\text {bis }}$ in Touchefeu-Meynier LIMC VII.1 1013. For another early West Greek depiction of the blinding of Polypheums, see Boardman (1998) fig. 484 (19 in Touchefeu-Meynier LIMC VII.1 1014), a late $6^{\text {th }}$ cent. PseudoChalcidian neck amphora from Vulci. For other depictions of the blinding see also the following entries in Touchefeu-Meynier LIMC VII.1 1014: 20, a hydria from Caere, circa 520 BC; 21, an oenochoe from Etruia, circa $500 \mathrm{BC} ; 23$, an amphora form Campania (?), early $5^{\text {th }}$ century; 24 , a Lucanian crater, $420-410$ BC. The blinding is also depicted on an early Etruscan vase, circa $650-625$ BC ( $27^{\text {bis }}$ in Touchefeu-Meynier LIMC VII.1 1014). See also Lowenstam (2008) 13-17 and Chapter 2 of Thomas (1971).

${ }_{478}$ Malkin (1998) 87-88, 161, 173-174.

${ }^{479}$ Malkin (1998) 164-165, 170-171.
} 
(Od. 9.116-142). ${ }^{480}$ For the Euboean and Etruscan colonists who invoked Odysseus, the Cyclops episode would have been exemplary of the colonial experience, of pushing into uncharted territory and encountering peoples different from one's own. ${ }^{481}$ Invoking Odysseus, the quintessential Greek explorer, would have been a way for Greek colonists to reinforce their Greek cultural identity in the presence of unknown peoples. Polyphemus, then, may be considered an expression of the Greek experience of the Other during the colonial push past the borders of the Greek world. The Cyclopes, after all, existed at the far reaches of the Oikoumene. ${ }^{482}$ Thus, early colonists of Sicily would have interpreted the Cyclopea in the context of colonization: Odysseus' exploration and encounter with the Cyclops would have been emblematic of their own voyage away from central Greece and encounter with strange peoples and lands.

By the $5^{\text {th }}$ century, however, the Cyclopes were no longer located at the very edge of the Oikoumene, they were on Sicily, by now well-established as a site of Greek civilization. Despite hundreds of years of Greek settlements and cities on the island, Sicily must have remained to some degree at the outskirts of the Greek world in the Hellenic cultural imagination. Even by the time of the Sicilian expedition, claims Thucydides, the Athenians had little knowledge of the

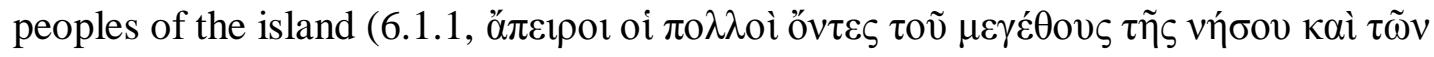

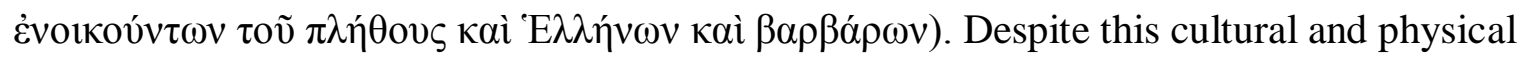
difference, however, the Cyclops now existed not at the very edge of the world, but at the edge

\footnotetext{
${ }^{480}$ Malkin (1994) 9; Malkin (1998) 160.

${ }^{481}$ There has been some debate recently over whether the Cyclopes actually symbolize the colonial experience. Malkin (1998) 21, for instance, stresses that the myth is never actually invoked in the founding story of any Greek colony, and so the episode should not be read as a "justification" for the violent expulsion of natives. That may be the case, but, given the oppositions employed by Homer (technology vs. lack thereof, brute strength vs. cunning, Cyclopes vs. Phaeacians etc.), I think we will be on safe ground if we contend that the Cyclopea is in large part about encountering a "less civilized" Other, a type of perception that would have been relevant to the situation of the Greek colonist.

${ }^{482}$ For the Cyclopes as beings at the far reaches of the Oikoumene, see Od.9.82-115 and Harrison (2002) 282-283.
} 
of the Hellenic world, as Odysseus makes clear in Euripides' Cyclops. Odysseus tells

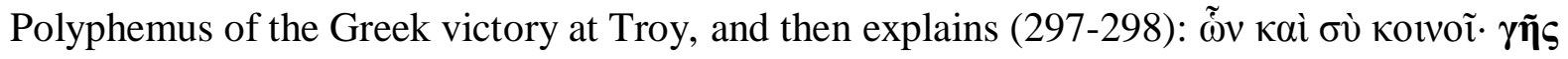

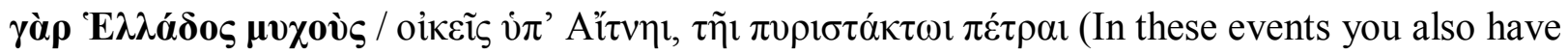
a share, dwelling as you do in the far reaches of Hellas, under Aetna, the rock that drips with fire; Trans. Kovacs). For Euripides, the volcano Aetna takes on an almost other-worldly mystique, pastoral and primitive. ${ }^{483}$ But Polyphemus himself resides in Sicily, a definite location within the Greek world. The associations with the barbaric Other, of the strange and the distant, inherent in the Homeric Cyclopea, have now been transferred to a long-established part of the Greek West. Theocritus' embrace of Polyphemus as his countryman is all the more striking in this light. The monster had previously been a symbol of the Other at the far reaches of the inhabited world, and then, in Euripides, the far reaches of the Greek world. This geographic distance was analogous to moral distance: Polyphemus was as barbaric and strange as he was distant. But in Idyll 11, the narrator is not at a remove from the monster. Rather, he equates the monster's voice with his own and seems to brag that he and the monster come from the same place. If geographic distance had previously been tantamount to moral distance, here Theocritus' claim of shared origin may be read as a statement of moral equivalence. And the poet has altered Polyphemus' character to suit - gone is the ferocious, unfettered, barbaric monster of the Odyssey, replaced with the lovelorn (but moderate) bucolic poet. Idyll 6 further emphasizes the monster's change of circumstance, virtually erasing the Odyssey narrative, ${ }^{484}$ and, contrary to previous depictions, suggesting that Polyphemus might just seduce Galatea after all, as the Sicilian historian Timaeus had already reported.

\footnotetext{
${ }^{483}$ Cusset (2012) 32-33.
}

${ }^{484}$ Cf. Hunter (1999) 247. 
Theocritus' recharacterization and embrace of the Cyclops as his countryman can be read as a validation of regional Sicilian culture and identity. Whereas Polyphemus had previously been associated with perceived negative aspects of Sicily (the tyrant Dionysius, gluttony and luxurious cooking, sophistry) and symbolized the barbarian at the end of the world as opposed to the culture of the "center" inherent in the colonial mindset, ${ }^{485}$ he now symbolizes Sicilian culture. He is no longer the Other encountered by the colonist to Sicily; he is a Sicilian, singing in the Sicilian mode of bucolic. And it turns out that his change of genres, from epic and comedy to pastoral, has also made him less barbaric and more convivial. Not only does the Cyclops sing in a Sicilian mode, he also seems to show a preference for Sicilian story traditions, as the local Timaean influence on Idyll 6 demonstrates. No longer, as in Book 9 of the Odyssey, is Polyphemus a character in one of Odysseus' tales, the monster from the far reaches of the world, nor is the Cyclops being mocked on an Athenian stage; the Sicilian Theocritus lets him sing for himself in the Sicilian style. Sicily is not now at the end of the world, but in the center of its own cultural sphere. ${ }^{486}$

\footnotetext{
${ }^{485}$ See Lowenstam (2008) 13-17, who argues that depictions of Polyphemus came to emblematize the dangers of colonization.

${ }^{486}$ There is a similar cultural pride on display in the fragments of the Sicilian historian Timaeus, a near contemporary of Theocritus. Baron (2012) concludes that Timaeus emphasized "the primacy of the western Greeks in political, cultural, and intellectual achievement, some of which was directed at an Athenian audience" (256) and that Timaeus was "a Sicilian Greek who extolled the greatness of his native land" (258).
} 


\section{Chapter 4: \\ Kunstsprache for the Common Man: Language and Identity in the Doric Idylls}

\section{INTRODUCTION}

An episode from Idyll 15 demonstrates Theocritus' preoccupation with the way that language and identity are intertwined. Two Syracusan women, emigrants to Alexandria, walk through the streets of that city on their way to a festival of Adonis. These ladies, Gorgo and Praxionoa, catch sight of a beautiful tapestry of the hero-divinity, which the latter excitedly describes. Her speech disturbs another member of the crowd, who grows annoyed at their broad Syracusan accents (15.78-93):

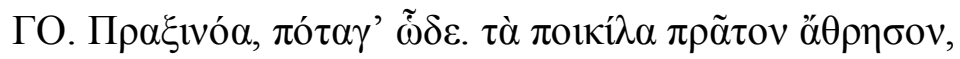

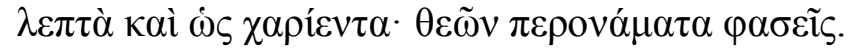

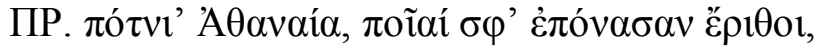

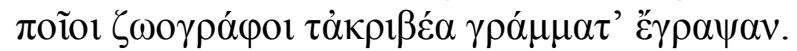

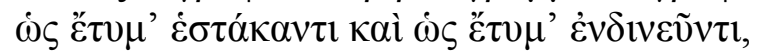

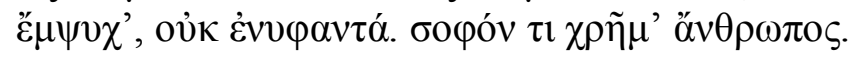

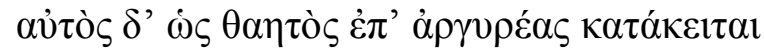

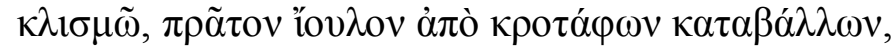

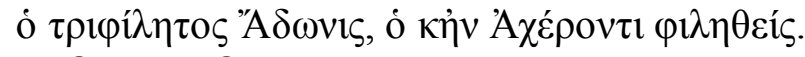

ETEPO $\Sigma$ ENO $\Sigma$

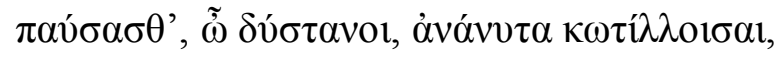

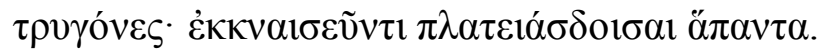

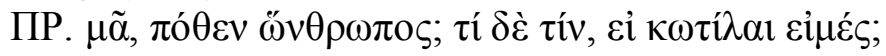

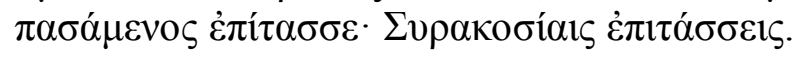

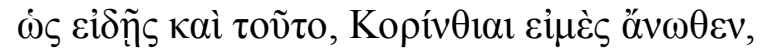

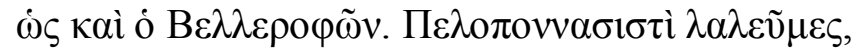

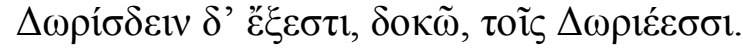

\section{GORGO:}

Praxinoa, come over here. First take a look at this embroidery; so fine and graceful. You'd say these tapestries were the garments of the gods!

\section{PRAXINOA:}

Oh queen Athena, what a labor, and for such spinsters! Such painters to plot their lines with so much precision! They stand there, like they're real; they waver there, like they're real, made of living souls, not wool. What a clever thing is man. And there's the boy himself, like a wonder, lying on his silver couch, the first down sprouting on his cheeks, thrice-loved Adonis, loved always, and even in Acheron. 


\section{SECOND STRANGER:}

Stop your cooing, you sorry little birds, it's endless! They'll talk our ears off, drawling on about everything.

\section{PRAXINOA:}

My goodness, where's he come from? What's it to you if we chatter? Go boss your slaves around. You're bossing Syracusans. And you'd better remember, that means we're really from Corinth, just like Bellerophon. So we talk in Peloponnesian, and I guess it's okay for Dorians to speak Dorian!

Praxinoa defends her manner of speech by reference to her Syracusan origins, which, in turn, she links back to the mainland prestige of Corinth and the Peloponnese, as well as the heroic tradition embodied by Bellerophon. Scholars have justifiably read in this passage a dramatization of contemporary pressures on dialect speakers to conform to the Hellenistic koine, and have argued that the passage establishes an opposition between Doric and non-Doric speech. ${ }^{487}$ While the interpretation of these lines is not without complication, especially since the speech of the Alexandrian stranger is undifferentiated from that of the Syracusan women, ${ }^{488}$ the exchange certainly highlights the issues of language and identity in the Idylls on a thematic level. As has been pointed out before, ${ }^{489}$ the situation in which the Syracusan women find themselves is analogous to that of Theocritus and his Doric Idylls in Alexandria: they are linguistic strangers in a strange place, speakers of a regionalized dialect in an age when the koine was increasingly standard.

Idyll 15 thus shows that Theocritus considered dialect a marker of regional identity and perceived language difference as a means of dramatizing cultural friction. Since the Doric of Idyll 15 falls into the same linguistic group as the bucolics and other urban mimes ${ }^{490}$ we should expect that the language of the pastoral poems bears a similar social significance. The point of

\footnotetext{
${ }^{487}$ Willi (2012) 265-288; Krevans and Sens (2007) 186-187. For a summary of the issues related to this passage, see Hunter (1996) 119-123.

${ }^{488}$ Hunter (1996) 119-120.

${ }^{489}$ Willi (2012) 280.

${ }^{490}$ Willi (2012) 267-268 with n. 4.
} 
this chapter will be to analyze a number of features of Theocritean Doric, in order to achieve a fuller understanding of its cultural meaning. In particular, I hope that this dialectal analysis may elucidate the social and cultural implications of Theocritean Doric with respect to three contemporary contexts: 1) the increasing prominence of the koine; 2) contemporary poetic experiments in Doric poetry; 3) the Doric of the Ptolemaic court and its poetic milieu. I offer a brief introduction to these points now.

1) Theocritean Doric stands in opposition to the Attic-Ionic koine. From the time of Philip II, the Macedonian royal house had used the Attic-Ionic koine as its official language, which Alexander carried with his armies across the known world; it remained the standard for the Macedonian rulers of Alexandria and the other Successor kingdoms, and became increasingly important to the inhabitants of those cities, even as they continued to speak their native dialects. ${ }^{491}$ Despite the continued existence of dialect speakers in places like Alexandria, and although Doric inscriptions persisted throughout the third century BC, it is clearly the dialect forms which are marked against the increasingly normative koine, and, as noted, various scholars have pointed to Theocritus 15 as a dramatization of the pressure on dialect speakers to conform. ${ }^{492}$ The degree to which the Doric Idylls stand in opposition to the koine depends in part upon the degree to which a contemporary audience would have found a given linguistic form unusual. By examining a number of rare Doric forms drawn from the bucolics and urban mimes, I hope to further refine the notion that the Doric Idylls stand in ideological opposition to the Attic-Ionic koine.

\footnotetext{
${ }^{491}$ Krevans and Sens (2007) 186-187; Clarysse (1998) 5. For a survey of the development of koine and its effect on local dialects, see Horrocks (2010) 79-108, esp. 79-90 and 98-99, where Horrocks discusses Theocritus. See also Brixhe (2010) 228-231; Tovar (2010) 255-256.

492 Krevans and Sens (2007) 187-188; Hunter (2005b) 188-189.
} 
2) Theocritean Doric is strongly marked against contemporary literary experiments in Doric, although a number of Hellenistic poets made occasional forays into poetry with dialect coloration, Doric or otherwise. ${ }^{493}$ Even in cases where poets did experiment with dialect, commentators tend to emphasize the superficiality of their efforts. Neil Hopkinson, for example, describes the Doric of Callimachus' Hymns 5 and 6 as "cosmetic" and "a thin veneer." "494 I will argue that Theocritus not only stands out as part of a literary cohort interested in dialect experimentation, but he is distinguished even from his like-minded contemporaries by the relative thoroughness of his experimentation. Although the Doric of the bucolic Idylls is a highly artificial Kunstsprache, one would be hard pressed to call it a veneer.

3) Theocritean Doric is marked as special in relation to the Doric of the Ptolemies, as well as the Doric poetry associated with the court. While the Attic-Ionic koine was the official language of their Empire, the Ptolemies considered themselves descendants of Heracles and of Argive royalty. ${ }^{495}$ This supposed connection to the Dorian hero and the royal house of Argos corresponded likewise to Ptolemaic claims upon the Doric dialect, which was the prestige language of Macedonian royalty. ${ }^{496}$ There is evidence, moreover, of an epigrammatic tradition with Doric coloration associated with the Ptolemaic house (though not all epigrams to the Ptolemies were in Doric, nor all Doric epigrams were for the Ptolemies), ${ }^{497}$ including portions of Posidippus' Hippica that glorify Lagid victories at the Olympics. ${ }^{498}$ Indeed, one of these

\footnotetext{
${ }^{493}$ Hunter (2005b) 198-199.

${ }^{494}$ Hopkinson (1985) 44; Hunter (2005b) 199.

495 Sens (2004) 74-75 with notes 43-4; Hunter (2005b) 194

${ }^{496}$ Clarysse (1998) 12; Clarysse (1998) passim for the dialect of the upper echelon in Ptolemaic Alexandria. See also Hunter (2005b) 195-197 for a similar reading with a slightly different emphasis. For (admittedly limited) evidence that a dialect close to Doric may in fact have been spoken in Macedonia, see Hunter (2005b) 195-196.

${ }^{497}$ Sens (2004) 75; Hunter (2005b) 195.

${ }^{498}$ Sens (2004) 73-75.
} 
Olympic epinician epigrams, for which Ptolemy Philadelphus is the imagined speaker, is written in a relatively strongly marked Doric, akin to the language of Pindar or Bacchylides (88 A-B): ${ }^{499}$

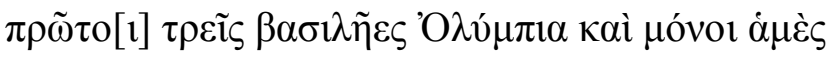

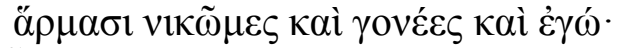

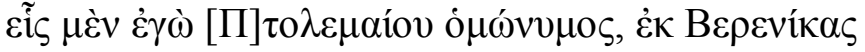

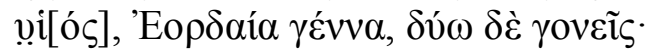

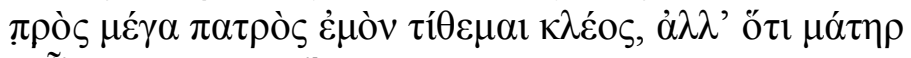

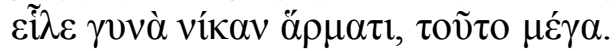

We are the first and only trio of kings to win

the chariot race at Olympia, my parents and I.

I, named after Ptolemy and born the son of Berenice, of Eordaean descent, am one, my parents the other two: and of my father's glory I boast not, but that my mother, a woman, won in her chariot - that is great! (trans. Nisetich)

Philadelphus here boasts of his connection to Macedonian Eordaia as well as his house's victories in the Olympics, all while speaking in the supposed Doric of his royal forebears. The Macedonian claim to Doric identity is on display. Despite the prestige of the Doric at the Alexandrian court, however, the dialect would fall out of favor in later years: Plutarch notes unfavorably the Ptolemies' eventual neglect of their "Macedonian" dialect (Life of Antony 27.4). As already noted, the pressure on Doric outside the court was becoming acute during Theocritus' age. Hunter has claimed that Doric used by Praxinoa in Idyll 15 draws an ideological link between her and the royal court. ${ }^{500}$ This may be true, in that both use the same dialect, but there are also differences. Praxinoa certainly does not seem to speak or behave like a member of the upper echelon, and nor do the characters of the bucolics. Rather, the Doric Idylls tend to leave the impression of being fairly popular, and their dialect thus stands in marked contrast to the language of Posidippus and the Ptolemaic court.

\footnotetext{
${ }^{499}$ Hunter (2005b) 195. Although this Epigram is strongly marked as Doric, we might also have expected Doric

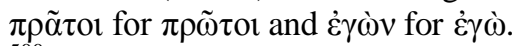

${ }^{500}$ Hunter (2005b), esp. 192-193, 196.
} 
These initial summaries provide some idea of the incredible complexity surrounding the dialect of the Idylls. It seems clear that the Doric Idylls must be strongly marked against the increasingly prevalent koine, but the precise details of that tension need further evaluation. Moreover, to grasp the cultural implications of Theocritean Doric, we need some way of gauging its relation to previous and contemporary literature, including the Doric experiments of contemporary poets in Alexandria or the Ptolemaic court. This chapter will address such needs by demonstrating that the dialect of the bucolics and urban mimes is the linguistic equivalent of the mythological figures treated elsewhere in this study. Namely, Theocritus' artificial Kunstsprache is an example of the poet's concern for Doric popular and local identity, and becomes a means of reflecting on those themes. The language of the bucolics and urban mimes does not precisely imitate any one historical epichoric dialect, as some scholars have tried to argue. However, Theocritean Doric does use a number of historical, highly regionalized, unliterary word-forms and lexemes, evoking with his fictional vernacular a popular epichoric Doric. By using such markedly unliterary forms, Theocritus’ Doric Kunstsprache creates ideological oppositions between Doric and non-Doric, local and pan-Hellenic, vernacular and literary. Before embarking upon a linguistic analysis of our own, however, we will begin by noting and evaluating some previous methods of approaching the question of dialect in the Idylls.

\section{PREVIOUS APPROACHES}

There has been a wide range of scholarly responses to the language of the Doric Idylls, a variety which corresponds to the eclectic nature of Theocritus' Kunstsprache. The bucolics and urban mimes contain many Homeric forms, as is to be expected from a hexameter poet, but they also contain Doric right alongside non-Doric features and juxtapose elements from various 
epichoric Doric dialects that never would have existed together in reality. ${ }^{501}$ This artificiality is further emphasized by the fact that two fairly common features of the Doric Idylls are in fact of dubious Doric pedigree. One of these is the orthography $-\sigma \delta$ - in place of $-\zeta-$, which tended to be used by Aeolic poets, though it is found in Alcman. If indeed Theocritus did write - $\sigma \delta$ - in place of $-\zeta-$, Alcman may have been his model. ${ }^{502}$ Another feature atypical of Doric is Theocritus' use of Moĩ $\alpha$ in place of Moṽ $\sigma$. The only regional Doric dialect to use Moĩ $\alpha$ was that of Cyrene, though it is, once again, characteristic of Lesbian Aeolic. And while this form does occur in Pindar, it is not found in other literary Doric, including that of Epicharmus and Sophron from Sicily. ${ }^{503}$ The Doric lyric poets who do use $-\sigma \delta$ - for $-\zeta$ - and Moĩ $\alpha$ may not have conceived of these forms as Doricisms, but used them in imitation of the Aeolic poets. ${ }^{504}$ In this case, then Theocritus or early editors of the Idylls may have written these forms to draw a connection with earlier Doric literary lyric, thus appropriating non-Doric features into Theocritean Doric. If Theocritus had been attempting to create a literary Doric that was simply a close approximation of an actual epichoric dialect, such forms likely would have been excluded given their scanty Doric pedigree and their probable literary origins. ${ }^{505}$

Even when Theocritus does use forms found in epichoric Doric dialects, he does so inconsistently. The bucolics and urban mimes vacillate between strong and weak Doric endings, for example. The Doric Idylls tend to employ - $\omega$ for in the genitive singular and - $\omega \varsigma$ or -ŏ $\varsigma$ in the

\footnotetext{
${ }^{501}$ Of course, Homer's literary language also juxtaposes forms never found together in a vernacular dialect. Thus, the concept of a Kunstsprache would not have been surprising to Theocritus' audience. On the Homeric dialect see Horrocks (1997) 193-217; Janko (1992) 8-19; Hainsworth (1988) 24-32.

${ }_{502}$ Hunter (1999) 24; Molinos Tejada (1990) 122-28; Dover (1971) xli.

${ }^{503}$ Dover (1971) xl-xli.

${ }^{504}$ Willi (2012) 271.

${ }^{505}$ See Ruijgh (1991), however, addressed further on, who argues that -olø $\alpha$ and other oddities of Theocritus' language are a feature of the Cyrenean Doric he proposes as the dialect of Idyll 15.
} 
accusative plural of the second declension (characteristic of strong as opposed to weak Doric). ${ }^{506}$ This pattern is surprising for several reasons. First, as noted by Dover, whose argument I follow here, these forms are uncharacteristic of Theocritus' native linguistic milieu: "the Dorian communities of Sicily, together with Kos, Rhodes and the neighbouring islands, uniformly show

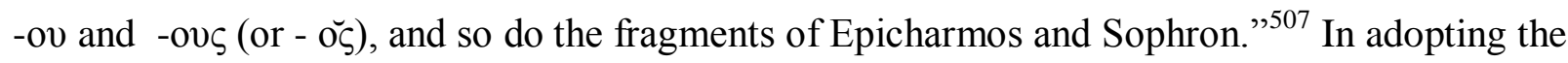
strong Doric forms, Theocritus links his literary dialect with that of Cyrene, South Italy and the Peloponnese. But strong Doric dialects (which employ $-\omega$ and - $\omega \varsigma$ in second declension gen. sg. and acc. pl., as Theocritus often does) tend to use - $\eta v$ for their active infinitive, whereas Theocritus tends to use $-\varepsilon i v$ and more rarely $-\varepsilon v$, while $-\eta v$ is much less frequent. ${ }^{508}$ These combinations of forms, then, make Theocritus' Doric unlike any actual epichoric Doric variant. $^{509}$

Dover concludes that Theocritus' extremely varied language did not belong to any one local Doric dialect, but that the poet, in addition to utilizing epic forms, “'shopped around' both in the dialects of his own day and in lyric poetry which had Dorian associations." ${ }^{510}$ Gow's summary of the linguistic situation is still relevant and states the issues even more exactly:

In short Theocritus' dialect is artificial, peculiar to himself, and not consistent even in his own usage. He is not writing his native Syracusan, nor is he imitating those who had written it before him (Epicharmus and Sophron, for instance) as in the Aeolic poems he imitates Sappho and Alcaeus, nor again is he trying to reproduce the dialect of a particular place as Aristophanes tries to reproduce the dialects of Laconia or Megara or Boeotia. ${ }^{511}$

\footnotetext{
${ }^{506}$ On the features of strong and weak Doric, see, e.g., Abbenes (1996) 3. See also Méndez Dosuna (2007) 451-452; Colvin (2007) 23, 45, 47; Molionos Tejada (1990) 46-47.

${ }^{507}$ Dover (1971) xl.

${ }^{508}$ It should be noted, however, that the earliest papyri have $-\eta v$ and not -EIv (though there are only two examples). See Molinos Tejada (1990) 71, 74-75.

${ }^{509}$ For a more thorough comparative analysis of Theocritus' Doric, see the still excellent section on dialect in Dover (1971) xxvii-xlv.

${ }^{510}$ Dover (1971) xlii. On linguistic difficulties in Theocritus in general, see Dover's excellent section on dialect xxvii-xlv, esp. xxxviii-xlv on the constituent elements of Theocritus' language and its differences from epic and koine dialects.

${ }^{511}$ Gow (1952) vol. 1 lxxiii.
} 
Theocritean Doric appears not to belong to any specific variety of epichoric dialect, but to include elements from a wide variety of locales, which never occurred together in reality. Moreover, the Doric draws upon high literary language even as it utilizes apparently unliterary forms. Meanwhile, epic forms occur throughout. While scholars like Dover and Molinas Tejada have done a superb job of identifying the constituent parts of Theocritean Doric, much interpretive work remains as regards the social and ideological valence of this literary dialect in its contemporary context, which will be the focus of this chapter.

In spite of this evidence that Theocritus constructs an artificial literary language, one way of responding to the conflicting data of Theocritus' Doric has been to attempt to find a real epichoric Doric that might possibly accommodate the apparently unrealistic conglomeration found in the bucolic Idylls and urban mimes. Thus Magnien (1920) has claimed that Idyll 15 (which belongs to a group of linguistically similar Idylls including the bucolics) ${ }^{512}$ was composed in literary Syracusan, also used by poets like Epicharmus and Sophron. But although Theocritus' Doric contains some elements of potentially Syracusan origins (e.g. $-\varepsilon \sigma \sigma l, 3^{\text {rd }}$ decl. dat. pl., which however also occurs in Homer and the lyric poets), much more notable are the easily recognizable non-Syracusan elements, such as feminine participles in -oเo $\alpha$ and the strong Doric second declension genitive singular and accusative plural endings $(-\omega$ and $-\omega \varsigma) .{ }^{513}$

Ruijgh (1991) has also attempted to find a historical analogue for Theocritus' Doric. He proposed to find an epichoric Doric dialect that matched the eclectic linguistic mélange we find in Theocritus, and put forth that of emigrants from Cyrene living in Alexandria. Ruijgh's suggestion is at first attractive, because third-century Cyrenaean, like Theocritus' Doric, utilizes both feminine participles in -ol $\sigma \alpha$ and strong Doric endings; this theory is also plausible on

${ }^{512}$ Gow (1952) vol. 1 lxxii; Willi (2012) 267-268.

${ }^{513}$ Willi (2012) 267; Magnien (1920) 65, 78-79. 
historical grounds, since Cyrenaeans accounted for a substantial portion of the population of Alexandria. ${ }^{514}$ But serious problems arise upon further consideration. ${ }^{515}$ First of all, it is virtually impossible to verify Ruijgh's theory since its main argument rests on phonological proofs that are not metrically guaranteed, namely, Theocritus' use of strong Doric endings in the second declension genitive singular $(-\omega)$ and feminine participles in -oı $\sigma \alpha$. In addition, Ruijgh is compelled to justify the odd combination of strong and weak Doric forms found in Theocritus, but not Cyrenaean Doric: by this theory the reason for the unusual combination in Theocritus of strong back vowels $(-\omega /-\omega \varsigma)$ and weak front vowels (contractions in $-\varepsilon 1-$ and $-\varepsilon 1 v)^{516}$ is that the Cyrenaean émigrés, whose language the poet borrows, had been living for some time in Alexandria, long enough for their accents to be affected by koine. Thus, what we get in Theocritus is a partially koineized version of Cyrenaean, in which the front vowels had been modified by contact with Alexandrian. ${ }^{517}$ There is, however, "not a single piece of independent evidence for such a mixed Alexandrian Doric dialect.. ${ }^{, 518}$ Nor is this the only inconvenient fact that Ruijgh must explain away. For example, Theocritus' Doric alternates between strong and weak Doric forms for the active infinitive of contract verbs, using both $\varphi \imath \lambda \varepsilon i \tilde{v}$ and $\varphi \imath \lambda \tilde{\eta} v$; but Cyrenaean Doric uses only $\varphi \imath \lambda \varepsilon ́ v$. Ruijgh attributes this discrepancy to the influence of Attic. ${ }^{519}$

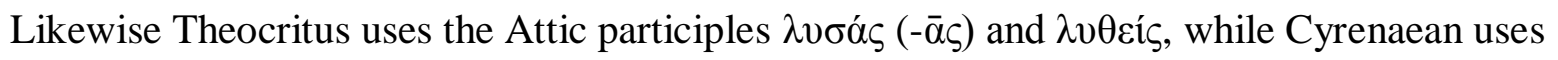
$\lambda v \sigma \alpha ́ \varsigma(-\breve{\alpha} \varsigma)$ and $\lambda v \theta \dot{\varepsilon} \varsigma .{ }^{520}$ Ruijgh must make special exceptions, sometimes invoking the influence of Attic and koine where convenient, thus assuming the influence of the mixed dialect

\footnotetext{
514 Ruijgh (1991) 408, 411.

515 See Willi (2012) 269-270; Hunter (1996) 37; Abbenes (1996).

${ }^{516}$ On these forms, see Molinos Tejada (1990) 71-74.

${ }^{517}$ Ruijgh (1991) 417-418; Willi (2012) 269-70.

${ }^{518}$ Willi (2012) 270. See also Abbenes (1996) 5.

${ }^{519}$ Willi (2012) 270 with n. 8; Ruijgh (1991) 423-425.

${ }^{520}$ Willi (2012) 270 with n. 8; Ruijgh (1991) 423-425.
} 
which he is attempting to prove. ${ }^{521}$ In a similar fashion, Ruijgh must assert that forms likely drawn from epic-Aeolic, with which Theocritus undoubtedly had contact in literature, are taken instead from the hypothetical dialect which he posits. According to Ruijgh, then, the particle $\kappa \varepsilon$, which is used by Theocritus in addition to the West Greek (and Cyrenaean) $\kappa \alpha$, is not borrowed from epic-Aeolic but from Alexandrian-Cyrenaean. ${ }^{522}$ Furthermore, Cyrenaean has second declension accusative plurals in -ŏ $\varsigma$. Theocritus also has second declension accusative plurals in ŏ, but much less frequently than - $\omega \varsigma$, which does not conform with Cyrenaean. ${ }^{523}$ Given these and other serious objections to Ruijgh's argument, ${ }^{524}$, the theory that the Doric Idylls are composed in and Alexandrian-Cyrenaean is implausible. ${ }^{525}$

That said, the attention that Ruijgh brought to bear on the discrepancy between strong and weak forms in Theocritus' Doric sparked a productive scholarly debate. Molinos Tejada (1990) also proposed a solution to explain to explain the different treatments of front and back vowels in the Doric Idylls. Rather than attempting to find an actual dialect to account for the odd mix of forms in Theocritus, Molinos Tejada proposes a solution that could only occur in a literary language. Whereas Ruijgh had proposed to explain the discrepancy as the result of phonological changes that occurred when Cyrenaean suffered the influence of the koine in Alexandria, Molinos Tejada suggests that the strange mix of forms is instead a result of

\footnotetext{
${ }^{521}$ Willi (2012) 270 with n. 8. See also Abbenes (1996) 11.

${ }^{522}$ Ruijgh (1991) 424-425; Abbenes (1996) 2.

${ }^{523}$ Ruijgh explains this discrepancy by suggesting that the short -ŏ $\varsigma$ of original Cyrenaean is changed to - $\omega \varsigma$ in the hypothetical Cyrenaean-Alexandrian blend under the influence of Attic/koine -ovs. However, for this hypothetical Cyrenaean-Alexandrian, he posits an asymmetrical vowel triangle, which allows for four degrees of opening on the front axis, but only three on the back axis. Thus, there is only one long-O vowel on the back axis, $\Omega$. Therefore, the Cyrenaean-Alexandrian adopts the length of -ovs, but not its quality. It is for this reason, he argues, that we only find accusative plurals in - $\omega \varsigma$ in Theocritus, and not -ovs. Abbenes raises objections to this line of thinking. See Abbenes (1996) 4, 15. See also Willi (2012) 269 with n. 7. Ruijgh (1991) discusses these forms on page 422.

${ }^{524}$ See Abbenes (1996) 2-3, 11, 15-16.

${ }^{525}$ See also Hunter (1996) 37.
} 
Theocritus' varying treatment of different morphological categories. ${ }^{526}$ Thus, the poet implements the strong Doric forms in highly productive morphological categories, like second

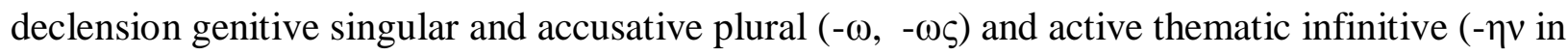
early papyri, though - $\varepsilon v$ is frequently written later) ${ }^{527}$ while the weak Doric forms are used in less productive categories, like contract verbs in - $-\dot{\omega} \omega$, Doric futures and in the nominative plural of $u / e w$-stems. ${ }^{528}$ Likewise, when a word with an o+o contraction belongs to an unproductive

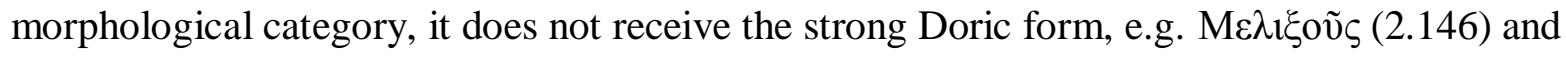

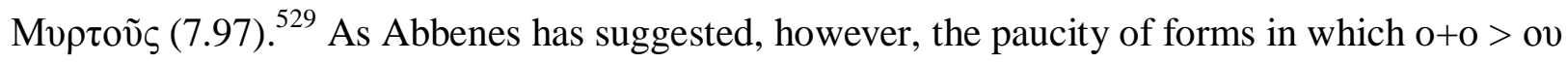
instead of $\omega$ in the Doric Idylls makes it difficult to verify that Theocritus is purposefully distinguishing between productive and non-productive morphological categories and choosing to utilize strong Doric forms only in the former. Molinos Tejada's theory on the inconsistency of strong and weak Doric endings, then, is similar to that of Ruijgh, in that both note the strange combination of forms found in Theocritus, which arises under the influence of the koine. But they are also importantly different: Ruijgh proposes that this Theocritean hodge-podge results from the evolution of a real dialect, whereas the individualized treatment of particular morphological categories envisioned by Molinos Tejada could only arise in a literary dialect, as Abbenes has noted. ${ }^{530}$

Abbenes (1996) also seeks to prove that Theocritus conforms to a literary dialect, in this case a dialect shared with the Doric poems of Callimachus, Alcman and certain Doric prose authors. Once again the focus is on the distribution of $\mathrm{E}$ and $\mathrm{O}$ vowels, a distribution that Abbenes determines to be very similar to that found in Alcman, as edited by Alexandrian editors

\footnotetext{
${ }^{526}$ Molinos Tejada (1990) 74-76. M. T.'s position is further discussed by Abbenes (1996) 5.

${ }^{527}$ Molinos Tejada (1990) 71, 74-75.

${ }^{528}$ Molinos Tejada (1990) 66-67, 73-76, with tables on pp. 68-73; Abbenes (1996) 5.

${ }^{529}$ Molinos Tejada (1990) 70, 73; Abbenes (1996) 5.

${ }^{530}$ Abbenes (1996) 5.
} 
with updated orthography. These editors are supposed to have altered the originally strong Doric text of Alcman and used the more varied orthography available in the Hellenistic era to render long $\mathrm{E}$ and $\mathrm{O}$ vowels. However they only use the orthography proper to strong Doric vowels in select morphological categories, in cases where unusual spellings would be unlikely to confuse non-Doric readers. ${ }^{531}$ Theocritus, then, mimics the vowel distribution that he had observed in Alexandrian editions of Alcman. ${ }^{532}$ Abbenes goes on to discuss the distribution of $\mathrm{E}$ and $\mathrm{O}$ vowels in Callimachus and various authors of Doric prose, and in light of their similar selective usage of strong Doric vowels, posits that they all share a literary language based upon the Alexandrian orthography of Alcman. ${ }^{533}$ While it is productive to think of Theocritus' language as a literary dialect, since it helps to focus our attention on the aesthetic motivations of the poet's linguistic choices, there are nonetheless difficulties with this theory. First of all, Abbenes' analysis, like that of Ruijgh, depends mainly on data that cannot be guaranteed by meter (long E and $\mathrm{O}$ vowels), so there will always be a degree of uncertainty. This indeed is highlighted when Abbenes draws attention to the fact that these Doric literary texts were edited in an Alexandrian context that was divorced from the circumstances of composition. ${ }^{534}$ Moreover, the long E and O vowels that makeup the centerpiece of Abbenes' argument may be too narrow a criterion upon which to base assertions about a shared literary language. Thus Willi points out several characteristics not common to Theocritus and Alcman:

Theocritus never has $\Sigma$ instead of $\Theta$ (which in Alcman frequently indicates a Laconian pronunciation $[\theta]$ instead of usual $\left[\mathrm{t}^{\mathrm{h}}\right]$, he does not close $\varepsilon$ to $\mathrm{i}$ before $o$ vowels and $a$-vowels (as in Alcman's fr. 1.98 oiai < $\theta \varepsilon \alpha i$ 'goddess'), he observes initial digamma much less regularly than Alcman, and he uses a good number of

\footnotetext{
531 Abbenes (1996) 16.

532 Abbenes (1996) 5-11.

533 Abbenes (1996) 11-17.

${ }^{534}$ Abbenes (1996) 8, 11.
} 
metrically guaranteed Doric futures (cf. Molinos Tejada (1990: 118: 118-20, 2937))..$^{535}$

Willi goes on to dispute Abbenes' notion that the strong Doric traits that are shared by the two poets are based in a strong Doric literary language that has been modified into mild Doric in select instances, to avoid confusion for non-Doric readers. ${ }^{536}$ Front vowels in both of these authors are more likely to be found in their weak rather than strong Doric forms; but it seems unlikely that a reader capable of interpreting endings in a strong Doric back-vowel (e.g. genitive singular in $-\omega$ ) would have been confused by forms that ended in a strong-Doric front vowel (e.g. active infinitives in $-\eta v$ ). Thus, it would make more sense to envision a scenario in which strong Doric forms were being added as a "patina," rather than a scenario in which a strong Doric literary language was being modified to avoid confusion. In this case, Theocritus would utilize the strong Doric forms most likely to create the impression of a strongly marked Doric in his reader. But there are issues even with this idea, Willi asserts. For instance, the poet praises Epicharmus as a paragon of Doric poetry, though the latter would have used the weak Doric

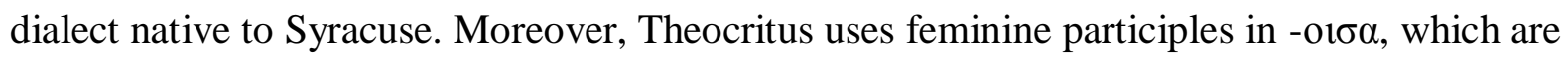
common in Doric lyric poetry, but are not characteristic of strong Doric outside of Cyrene. So it is unlikely that Theocritus was imitating Alcman's severe Doric literary koine or adding the forms merely as a patina. But what exactly was he doing?

Willi (2012), in his analysis of the language of Idyll 15, which he considers to be basically the same as that of the bucolics, argues that, instead of adopting a literary language based on the Alexandrian orthography of Alcman, Theocritus adds a strong Doric "patina" to his language, which he utilizes in "only the most conspicuous lexemes and categories." ${ }^{, 537}$ He thus

\footnotetext{
${ }^{535}$ Willi (2012) 271.

${ }^{536}$ Here and in what follows I summarize Willi (2012) 272-274.

${ }^{537}$ Willi (2012) 273.
} 
agrees with Abbenes (who was building on Molinos Tejada) that Theocritus must be using an artificial literary language which affected only certain morphological categories, rather than resulting from vernacular phonological changes. Where Willi really differs from Abbenes is in the rationale he posits for Theocritus' strong Doric patina. Rather than simply mimicking Alcman or only using strong Doric forms where it will not cause confusion for non-Doric readers, Willi suggests that Theocritus is making a social point: emphasizing the 'broadness' of Doric vowels — as the open $\omega$ was presumably perceived — compared to the closed quality of the increasingly prominent koine (cf. the Stranger's complaint to Gorgo and Praxinoa at 15.88 that they are "broadening" all their vowels $[\pi \lambda \alpha \tau \varepsilon \varepsilon \dot{\alpha} \delta o เ \sigma \alpha 1])$. Thus, the point is not to mimic any particular author or individual epichoric dialect, but to oppose Doric to koine in general. Theocritus dramatizes this conflict of dialects in Idyll 15, with which this chapter began, where an Alexandrian stranger criticizes two Syracusan women, Praxinoa and Gorgo, for speaking in their broad Doric accent. According to Willi, the stranger's point is not to mock the women for their Syracusan accents in particular, but for speaking any variety of Doric at all. As it happens, the best way to emphasize this discrepancy between Doric and koine is by utilizing long $\mathrm{O}$ and $\mathrm{E}$, which were closer in koine than in Doric. But what of the fact that Theocritus' Doric is not consistent in its use of long $\mathrm{E}$ and $\mathrm{O}$ vowels, which Molinos Tejada and Abbenes have argued only occur in select morphological categories? Willi argues that such variation by category need not concern us, since "there was no need to do this [i.e. use the graphemes $\Omega$ and $\mathrm{H}$ instead of OY and EI] with absolute consistency, because the alternate orthography served merely as a signal. Moreover, this scenario may even explain why there is overall more consistency in the use of $\Omega$ as compared to that of H., ${ }^{538}$ Theocritus may not use strong Doric spellings everywhere

\footnotetext{
${ }^{538}$ Willi (2012) 276-77. Willi likens the inconsistency in the use of these graphemes to the inconsistent spelling of
} [zd] in Alcman. Alcman often but not always writes of word-internal - $\zeta$ - as $\Sigma \Delta$ (Willi 274). But why use $\Sigma \Delta$ instead 
he could have, but he does so with enough frequency to emphasize his kinship with the Doric women of Idyll 15, thus positioning Doric as a "counter-language" in opposition to the expected "standard.",539

In Willi's view, then, the language of Idyll 15, and therefore of the Doric Idylls in general, is meant to highlight their broadly Doric character rather than their allegiance to any particular Doric locale: "Thus, what is at stake in Theocritus is not Laconian, Syracusan or Cyrenaean, and not Mild Doric or Strong Doric either, but simply Doric or not Doric." ${ }^{240}$ The women use a Doric koine rather than the language of any particular Doric place. ${ }^{541}$ The conflict between Gorgo and Praxinoa and the Alexandrian stranger in Idyll 15 is a microcosm of a much larger regional tensions: the center vs. the periphery, East vs. West, Sicily and Doric Greece vs. Alexandria. According to Willi, the Syracusan women dramatize a real contemporary cultural struggle: that to become the new center of Greece. ${ }^{542}$ This fictional confrontation, in turn, dramatizes the literary conflict created by Theocritus' Doric Idylls: they are radical, literary outsiders, Doric dactylic poetry pushing back against epic, Alexandria and the literary canon. ${ }^{543}$ Willi is right to point out the huge cultural issues at stake in the spat between the Syracusan women and the Alexandrian stranger. Yet there are problems with his argument. First, Willi's emphasis on Doric culture as a whole risks overlooking important aspects of Theocritus' language. For example, while it is certainly true that Theocritus enacts an opposition between Doric and non-Doric poetry, Theocritus also takes special care to include non-literary, popular

of $\mathrm{Z}$, which represented [zd] in Lesbian inscriptions? The spelling $\Sigma \Delta$, claims Willi, was introduced once " $\mathrm{Z}$ was $n o$ longer pronounced as [zd], but had become [z] in Attic/koine Greek." Thus, $\Sigma \Delta$ was now the only spelling that could ensure the pronunciation [zd]. The poet does not use the orthography $\Sigma \Delta$ with complete consistency, but he need not do so: frequent use is enough to signify to the reader that both $-\zeta-$ and $-\sigma \delta$ - are to be pronounced [zd] (Willi $274-$ 275).

${ }^{539}$ Willi (2012) 280.

${ }^{540}$ Willi (2012) 278.

${ }^{541}$ Willi (2012) 282.

${ }^{542}$ Willi (2012) 280-284.

${ }^{543}$ Willi (2012) 280. 
elements of speech. Simply asserting that Theocritus uses a literary Doric koine means overlooking the strange amalgam of forms that the poet uses. In addition to enacting a conflict between Doric and non-Doric literature, then, Theocritus also uses language to create an opposition between popular/rustic and literary, as argued below. Moreover, as we have seen before, arguments about the strong or weak coloration of long $\mathrm{E}$ and $\mathrm{O}$ vowels will always be somewhat uncertain, due to the chaos of the manuscript tradition and the impossibility of metrical confirmation for such forms. It is of the utmost importance, therefore, to base the linguistic analysis of Theocritus upon a foundation of metrically guaranteed forms.

In this respect, an important model for my argument is that of Richard Hunter (1996), who uses metrically guaranteed forms to support Gow's division of the Idylls into various linguistic categories. Gow had posited 5 categories:

(i) Genuine poems in Doric: Idd. 1-7, 10, 11, 14, 15, 18, 26.

(ii) Dubious or spurious poems in Doric: Idd. 8, 9, 19-21, 23, 27.

(iii) Poems prevailingly in Epic dialect with an admixture of Doric: Idd. 13, 16, 17, 24.

(iv) Poems in Epic and Ionic: Idd. 12, 22, 25.

(v) Poems in Aeolic: Idd. 28-31. ${ }^{54}$

While these categories make good sense of the evidence on the page, such as it is, the chaos of the manuscript tradition might make it difficult to know with any certainly whether such linguistic divisions are well founded. Fortunately, Hunter has laid a solid foundation for Gow's categories by analyzing metrically guaranteed forms. In this light, a brief survey of the troubles plaguing the textual tradition is called for, which will also demonstrate the necessity of basing linguistic analysis on metrically guaranteed features.

Since the papyri and manuscript tradition of Theocritus are highly unreliable in matters of dialect, it is impossible in many instances to know what the poet wrote. ${ }^{545}$ Questions of dialect

${ }^{544}$ Gow (1952) vol. 1 lxxii. 
will often hinge on phonological variants that are metrically equivalent, and the papyri and manuscripts of Theocritus indeed show such variation between different dialectal forms under these circumstances (e.g. weak vs. strong Doric). ${ }^{546}$ This variation would not be so grave a difficulty if the manuscript tradition showed a straightforward degradation from more Doric to less Doric, or, indeed, a hypercorrection in the direction of more marked dialectal forms.

Unfortunately, the situation is more complex than that. In some cases, the papyri and manuscripts show a clear trend towards the elimination of Doric forms that must have been unfamiliar to the scribes who transmitted the texts. Thus, the tradition demonstrates a clear movement away from Doric $\bar{\alpha}$ to Ionic $\eta$, away from certain instances of compensatory lengthening with Doric coloration (e.g. $\eta$ is largely replaced by $\varepsilon 1$ in the MSS), as well as a decreasing use of Doric accentuation (e.g. the first and second declension endings -ot and - $\alpha$ are treated as long for the purposes of accentuation in the older, more Doric papyri, but as short in later papyri). ${ }^{547}$ In other instances, however, the tradition appears to have come to associate certain linguistic characteristics with bucolic poetry, and thus made a concerted effort to promote these forms. For example, Molinos Tejada's analysis of the papyri and manuscripts, ${ }^{548}$ followed here, indicates an increased preference over the centuries for $-\sigma \delta$ - in place of $-\zeta_{-}$, even though $\sigma \delta$ - is not clearly characteristic of Doric to begin with. Scholiastic evidence indicates that $-\sigma \delta-$ may have been used as early as the Alexandrian period, yet the papyrus $\mathrm{P}_{1}$, for instance, which dates from the second century $\mathrm{AD}$ and which preserves other characteristically Doric readings, transmits no readings of $-\sigma \delta$ - for $-\zeta-$. The later papyri and the manuscripts tend to vacillate, and provide a very confused array of data from which to draw conclusions, but nonetheless show an

\footnotetext{
545 Gow (1952) vol. 1 lxxiii-lxxv; Dover (1971) xxxii-xxxvii; Molinos Tejada (1990) iii-iv, 374 and passim; Hunter (1996) 35-36.

${ }_{546}$ Molinos Tejada (1990) does a very thorough dialectical analysis of the extent papyri and mss.

${ }^{547}$ Molinos Tejada (1990) 6, 17-19, 53, 367-371.

${ }^{548}$ Molinos Tejada (1990) 122-128, 372-373. See also Gow (1952) vol. 1 lxxiv.
} 
increased preference for $-\sigma \delta$ - in place of $-\zeta$-. In this case, therefore, regardless of what Theocritus actually wrote, the transmitters of the text may have come to associate $-\sigma \delta$ - with the bucolic mode, ${ }^{549}$ and thus favored it to an increasing extent. Other dialectical forms display a similar pattern. Thus, although there was a tendency to "resolve" many Doricisms to "normal," nonDoric forms over the course of transmission, some examples show just the opposite trend. Thus, the restoration of Theocritus' text will not be a simple process of restoring the "most Doric" reading in every instance.

Given the difficulty of the manuscript tradition, Gow's five linguistic categories might conceivably be the result of a feedback loop, in which assumptions about genres led early editors to prefer one dialect over another for a given poem. Thus, associations between Doric and rustics in the minds of ancient critics, may have led to the imposition of Doric forms upon the bucolics and urban mimes (which belong to Gow's first group). ${ }^{550}$ The only instances in which we may be confident of what Theocritus actually wrote are those which are guaranteed by the meter. It is these forms, therefore, that must provide the basis for any linguistic analysis.

Such metrically guaranteed forms provide the basis in Hunter's work for the verification of Gow's groupings, thereby establishing certain basic facts about Theocritus' language to act as guidelines for thinking about non-metrically guaranteed forms. ${ }^{551}$ For instance, Hunter notes that frequent omission of the article is a mark of high literary poetry. The bucolics and urban mimes (found in group one), however, tend to use the article far more than the poems of groups three and four. Thus, the relative frequency of articles in most poems in group one indicates an effort

\footnotetext{
549 This orthography may have been considered "Doric" due to its presence in editions of Alcman (where it may simply have been borrowed from Aeolic lyric). Editors might subsequently have inserted this supposedly Doric orthography into the bucolics, mistakenly thinking it appropriate to their dialect. See Molinos Tejada (1990) 372.

${ }^{550}$ Cf. Hunter (1996) 38-39.

${ }^{551}$ Hunter (1996) 39.
} 
to distinguish them from Homer and high literature while aligning them with everyday speech. ${ }^{552}$ Likewise, the trisyllabic form $\ddot{\eta} \lambda v \theta \varepsilon s$, characteristic of epic and high lyric, appears as the first word of Idyll 12 (group four), and again in anaphora in the first word of the second line, but never occurs in the Doric poems. However, the Doric Idylls do utilize the less marked disyllabic version $\tilde{\hat{\eta}} \lambda \theta$ ov or its Doric equivalent $\tilde{\eta} v \theta o v .{ }^{553}$ The distribution of such metrically guaranteed forms suggests that Gow's linguistic categories may be accurate, and provides a solid context for Hunter to evaluate the distribution of forms which cannot be metrically guaranteed.

Following Hunter's example, my own analysis will focus in the first instance upon metrically guaranteed evidence and markedly Doric lexemes. Hunter's confirmation of Gow's linguistic classification can be further supported by paying particular attention to the cultural and social connotations of a number of rare word-forms. This approach picks up on that of Willi, who very attractively argues that Theocritus' artificial, literary Doric, creates a strong opposition between Doric and non-Doric, by contrasting Doric features with koine features. Yet even Willi's formulation does not fully describe Theocritus' linguistic goals. Although the amalgam of forms from distinct regional dialects found in the Idylls does not imitate any one historical regional Doric, the use of strongly marked, unliterary regionalisms is enough to enact a second ideological opposition, between pan-Hellenic and local language. Thus, Willi is right to suggest that it doesn't much matter whether a given form is Coan, Syracusan, Cyrenaean, etc. But it does matter that the form appears to be from a particular region, rather than part of a literary Doric koine. The fact that Theocritus uses forms unfamiliar from other Doric literary authors raises the

\footnotetext{
552 Hunter (1996) 39-40.

${ }^{553}$ Hunter (1996) 40-41. In addition, although Doric $\tilde{\eta} \varsigma$ may never be guaranteed against $\tilde{\eta} v$, it is possible to

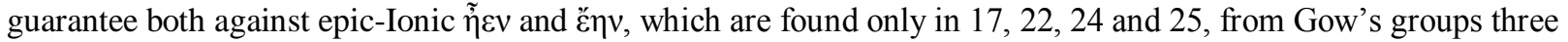

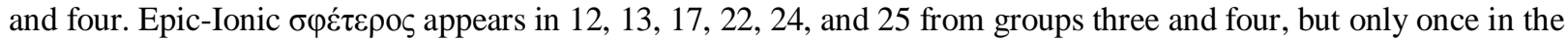
Doric poems, in Idyll 21, which is likely spurious. Similarly ö $\varphi \rho \alpha$ occurs only in groups two, three and four, as does

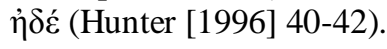


possibility of a third ideological opposition, between literary and un-literary language. The whole point of including such words and forms in the Idylls is that they are unusual and not shared by literary society - they are distinctly non-koine. The fact that most of the forms to be treated here are extremely uncommon in previous or contemporary literature is important to highlight, since the use of such strongly marked, unliterary forms allows us to draw a distinction not only between Theocritus and epic, but also previous Doric poetry or the Doric experimentation of his contemporaries. In addition to creating oppositions between Doric and non-Doric language as Willi rightly suggests, therefore, the language of the Idylls also creates ideological oppositions between local and pan-Hellenic, as well as non-literary and literary language.

By necessity, this chapter makes no claim to exhaustiveness, but discusses only a select number of metrically guaranteed forms, which nonetheless demonstrate the strongly marked, idiosyncratic nature of Theocritus' Doric with respect to his predecessors and peers: first and

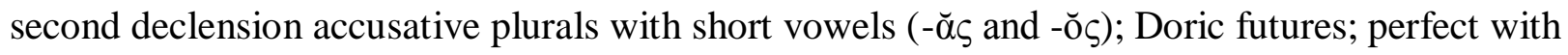
present endings; $\pi \rho \tilde{\alpha} v, \pi \rho \omega ́ \alpha \nu$ and $\pi \rho o ́ \alpha v ; \tau \varepsilon \tilde{u} \varsigma$. The analysis of these dialect features is followed by discussion of a small number of Doric lexemes.

\section{ANALYSIS}

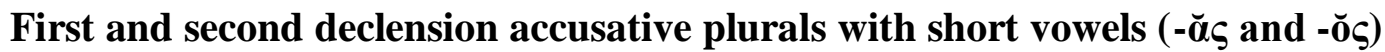

Theocritus treats first and second declension accusative plurals in two different ways. The loss of the inherited nasal may result in compensatory lengthening (e.g. $*_{\text {-ans }}$ and $*_{\text {-ons }}>$ $\bar{\alpha} \varsigma$ and -ov $\varsigma$ ). But Theocritus also uses first and second declension accusative plural endings with short vowels, much rarer forms, in which the nasal is simply lost $\left(*_{\text {-ans }}\right.$ and $*_{\text {-ons }}>-\breve{\alpha} \varsigma$ and ŏ $).{ }^{554}$ These short-ending accusatives are found in a number of Doric dialects, like Coan and

\footnotetext{
${ }^{554}$ On these forms in general, see Molinos Tejada (1990) 163-168 and Hunter (1999) 91-92.
} 
Cyrenean. ${ }^{555}$ Although first attested in Hesiod (Shield 302), these forms, when they do appear, have a strong association with Doric literary authors; in addition to Theocritus, they are found in the works of Alcman, Tyrtaeus, Stesichorus, Simonides, Epicharmus, Empedocles, an anonymous Rhodian chelidonismos (swallow-song, quoted at Athenaeus 360c), and Leonidas of Tarentum. ${ }^{556}$ Theocritus treats these short-ending accusative plurals as distinctly Doric forms: none of the 28 instances in the Idylls appear outside the bucolics or Doric mimes. ${ }^{557}$ In this sense, Theocritus seems to be using these short accusative plural forms (among others) to mark the Idylls in which they appear as linguistically and stylistically Doric. ${ }^{558}$ But while the ability to group the Idylls into broad linguistic categories is extremely valuable, ${ }^{559}$ the evidence at our disposal on accusative plurals in short -ă $\varsigma$ and -ŏ $\varsigma$ makes a more nuanced analysis both possible and necessary, if we are to understand the full implications of the poet's choice of these forms. This analysis will demonstrate that Theocritus uses these unliterary short-vowel accusative endings with much greater frequency than his predecessors; the distribution of nouns in -ŏ $\zeta$, the rarer form of the two, will show that Theocritus intends these endings to evoke rustic vernacular Doric.

While short - ̌̆ $\varsigma$ plural accusatives are fairly common in Doric literature before Theocritus, short -ŏৎ plural accusative endings are extremely rare. Counting forms from both declensions, there are roughly 50 instances of these short accusative forms in Greek literary texts, of which 28 appear in Theocritus. Out of all these examples only 9 are plural accusatives in -ŏ$\varsigma$, of which fully 7 occur in Theocritus, each of which is metrically guaranteed. In other words,

\footnotetext{
${ }^{555}$ Hunter (1999) 92. Cf. Molinos Tejada (1990) 168 and Buck (1955) 68: “Accusatives in -o, , $\alpha \varsigma$ are the regular forms in Thessalian, Arcadian (so probably Cyprian -o $\varsigma$ not -ō $\varsigma$ ), Theran, Cyrenaean, Coan, and are occasionally found in other Doric dialects and in literary Doric (e.g., frequent in Theocritus)." See also Morpurgo Davies (1964) 155 , n. 2.

${ }_{557}^{556}$ Molinos Tejada (1990) 164, with note 228. For a list of citations, see Troxler (1964) 74-76.

${ }^{557}$ Hunter (1996) 44 n. 173; Molinos Tejada (1990) 166.

${ }^{558}$ Hunter (1996) 38-45 has concluded as much, using these and other forms as evidence.

${ }^{559}$ Cf. Hunter (1996) 38 and above, 194.
} 
there are only two instances of plural -ŏ $\varsigma$ accusatives in Greek literature outside of the Idylls, compared to as many as 20 of the $-\breve{\alpha} \zeta$ ending .560

One of the non-Theocritean examples occurs in the Shield of Hesiod (302). As Morpurgo Davies has argued, however, the short $-\breve{\alpha} \varsigma$ and -ŏ $\varsigma$ accusatives in Hesiod are probably not the result of Doric influence on that poet's language. Rather, they ought to be considered metrical variants left over from an earlier stage of development in the epic language, when some formulae still distinguished between long and short accusative endings (as was likely to be the case, for example, in Attic-Ionic, Boeotian or Lesbian, as Morpurgo Davies argues). ${ }^{561}$ If the short plural accusative endings are simply a vestige of an earlier period in the epic tradition, there is no need to postulate Doric influence on the text of Hesiod. ${ }^{562}$ (On the other hand, Davies speculates that Theocritus' use of short plural accusatives likely arose through direct contact with "some Doric dialect”..) $)^{563}$

If the example from Hesiod is disqualified on these grounds, then the sole remaining instance of a short -ŏ $\varsigma$ accusative plural ending before Theocritus comes from a trochaic

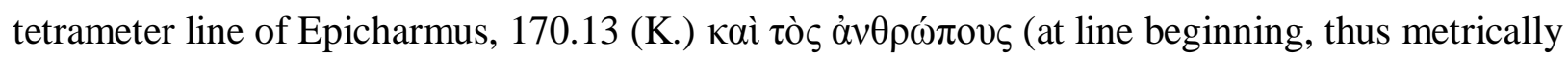
guaranteed). However, Kassel and Austin place this fragment among the Pseudepicharmeia, derived from Alcimus, the $4^{\text {th }}$ century B.C. Sicilian historian (276.7 K.-A.). Olson notes that Alcimus' Pseudepicharmic material "is more reminiscent of the real Epicharmus than is that of the other pseudonymous" fragments. ${ }^{564}$ It may be, therefore, that Alcimus of Sicily's quotation of

\footnotetext{
${ }^{560}$ Molinos Tejada (1990) 164-165.

${ }^{561}$ Morpurgo Davies (1964) 161. On short accusative plurals in Hesiod more generally, see 152-165. Against Morpurgo Davies' interpretation of the short -ă

562 Morpurgo Davies (1964) 159.

${ }_{563}$ Morpurgo Davies (1964) 164.

${ }^{564}$ Olson (2007) 10.
} 
the short -ŏ $\varsigma$ accusative reflects the actual practice of the Syracusan poet, as it was certainly intended to do.

But while there is virtually no literary evidence for -ŏ $\varsigma$ before Theocritus, it is wellattested in the vernacular of various Doric locales (though not in Sicily ${ }^{565}$ ). Short -ŏ $\varsigma$ accusative endings appear in the inscriptions of Cyrene, Thera and Cos, for example. ${ }^{566}$ The short -ŏ $\varsigma$ endings, then, are demonstrably part of the Doric vernacular, and markedly un-literary, even from the standpoint of Doric literary tradition. Theocritus' use of this form, therefore, constitutes a strong ideological link between the language of the Doric Idylls and the language of the vernacular. While the language of the bucolic Idylls is not an accurate representation of any one local Doric dialect, the inclusion of markedly vernacular forms like the short -ŏ $\varsigma$ plural accusative endings evokes a purposefully unspecified vernacular, non-literary Doric dialect.

The distribution of short -ŏ $\varsigma$ plural accusative endings in Theocritus supports this view. It has already been noted that the use of both short - $\breve{\alpha} \varsigma$ and -ŏ $\varsigma$ endings is limited to the bucolics and Doric mimes. The seven instances of short -ŏ $\varsigma$ accusative plural endings occur only in three Idylls, each bucolic, each connected to Sicily or South Italy: 1.90, 4.11, 5.84, 106, 109, 112, 114. It is worth noting that Idylls 4 and 5, in which 6 out of the 7 examples occur, are two of the most 'realistic' of the bucolics, in that they eschew the overt use of mythical figures, focusing instead upon mime-like depictions of rustic figures. ${ }^{567}$ Idyll 5, a poem full of proverbs and coarse language, is the most extreme in this regard. It is no accident, therefore, that it contains 5 of the 7 examples of this heretofore non-literary, vernacular form. What is more, the colloquial diction of

\footnotetext{
${ }_{565}$ Molinos Tejada (1990) 168.

${ }^{566}$ Buck (1955) 68; SEG 20716.25 (Cyrene); IG XII.3 330.13, 15 and passim (Thera); SEG 51 1050.15, 18 (Cos); Segre Iscr. di Cos ED 206.8.

${ }^{567}$ Cf. Crane (1988) 107-122, esp. 110.
} 
Idyll 5 coheres well with its amoebic form, essentially popular in nature. ${ }^{568}$ The use of Doric vernacular forms such as the short -ŏ $\varsigma$ accusative endings would thus be appropriate to a poem mimicking a popular song style. Nor does it matter that there is no epigraphic evidence for the use of such forms in Southern Italy: ${ }^{569}$ the point of including Doric vernacular forms is to create a creditable evocation of vernacular speech, rather than one that is factually accurate and precisely tailored to a particular Doric region.

The specific contexts in which the plural accusative -ŏ $\varsigma$ endings occur are instructive as well, as they are in each case appropriately popular and rustic. ${ }^{570}$ At Idyll 1.90, the Sicilian shepherd Thyrsis uses this ending at a point when he is impersonating Priapus in his song about

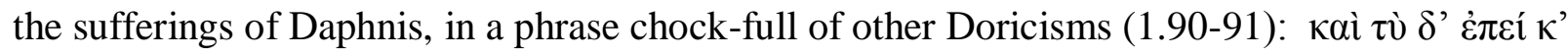

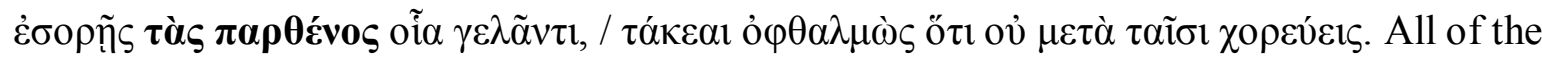
remaining 6 examples occur in words relating to animals or plants, further emphasizing the strong link between this vernacular form and popular or rustic subject matter. At Idyll 4.11, the short - $\breve{\varsigma} \varsigma$ accusative is used of wolves, and embedded in a phrase that seems proverbial, or at

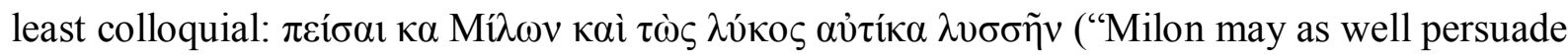
the wolves to go mad straight away"). In Idyll 5, the form occurs relating to goats that have born

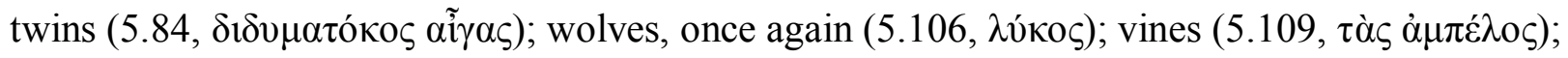

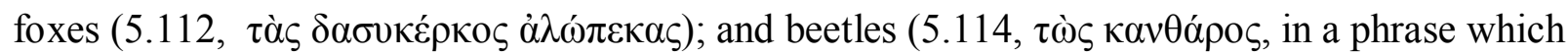
also utilizes the article associated with Doris severior). The dense distribution of short -ŏ $\varsigma$ endings in the fifth Idyll—five times in thirty-one lines, all in agricultural words-is clearly intended to highlight the vernacular quality of the speech of these two South Italians. The dense

\footnotetext{
${ }^{568}$ Hunter (1999) 6.

${ }^{569}$ Molinos Tejada (1990) 168.

${ }^{570}$ For a table of the uses of short - $\breve{\varsigma} \varsigma$ and -ŏ $\varsigma$ plural accusative endings in Theocritus, see Molinos Tejada (1990) 166.
} 
distribution of the short -ŏ $\varsigma$ accusatives in Idyll 5 emphasizes that Theocritus seems to be doing something truly radical here: in a non-comedic context, he initiates an actual vernacular form into the realm of high, literary, dactylic poetry. ${ }^{571}$

\section{Doric futures}

The Doric future, which is common to all Doric sub-dialects, "is a blend of the sigmatic

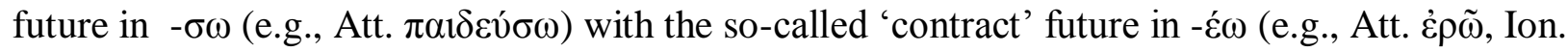

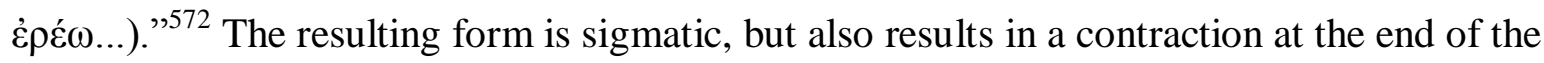
future stem. ${ }^{573}$ Due to this lengthening, Doric futures are frequently confirmed by the meter, as at

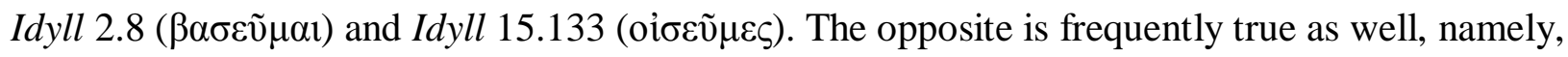

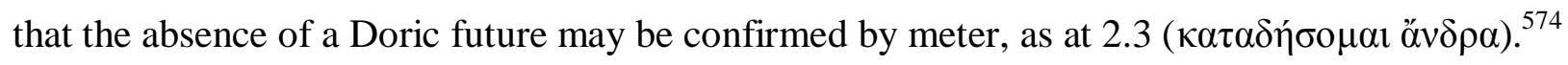
It is notable that Doric futures are attested right alongside normal sigmatic futures, as in the examples from Idyll 2 cited above (2.8 Doric, 2.10 non-Doric). It is equally as important to note, however, that both types of futures exist side by side in epigraphic evidence (e.g. IG XIV 645,

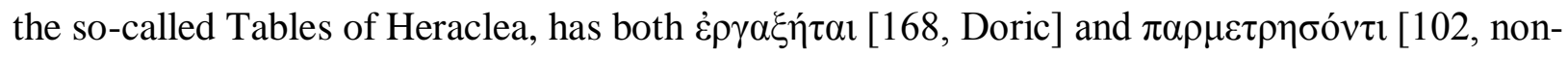
Doric]). ${ }^{575}$

Although the Doric future is common in Doric inscriptions, it is very rare in literature, save for in Sicily, especially Syracuse. ${ }^{576}$ A certain number of Attic authors use futures of this

\footnotetext{
${ }^{571}$ Cf. Fantuzzi and Hunter (2004) 133-141.

572 Méndez Dosuna (2007) 448-449, quote from 449.

${ }^{573}$ Méndez Dosuna (2007) 449: “A few Attic verbs have middle futures of this type: e.g., $\varphi \varepsilon v \xi o \tilde{\mu} \mu \alpha$, $\kappa \lambda \alpha v \sigma o \tilde{\mu} \alpha$ l, $\pi \varepsilon \sigma o \tilde{\mu} \mu \mathrm{l}^{.}$,

${ }_{574}^{574}$ Dover (1971) xliv, who cites these examples.

${ }^{575}$ In the case of the first person singular active and second person singular middle, accents are the only way to distinguish between Doric and non-Doric futures (Dover [1971] xlv; Molinos Tejada [1990] 294). Molinos Tejada has a very helpful table of all other examples of futures (Doric and non-Doric) in Theocritus (294-296). Note that the Doric future of the $3^{\text {rd }}$ person plural is not guaranteed by meter (cf. Molinos Tejada [1990] 296). Of these there are five instances out of the 23 Doric futures in Molinos Tejada's table, at 4.26, 7.57, 7.71, 15.88 and Ep. 7.4.

${ }^{576}$ Magnien (1912) 380-3; Willi (2008) 128-129.
} 
type, but only in the middle, ${ }^{577}$ and it also appears in Aristophanes' imitation of Megarian Doric, as well as in a fragment of Xenophanes, where the speaker is Syracusan. ${ }^{578}$ There are no metrically guaranteed examples in Pindar, Alcman, Bacchylides, Simonides, Stesichorus or Ibycus. ${ }^{579}$ Callimachus, on the other hand, has four metrically guaranteed instances, all in the Doric Hymns 5 and $6{ }^{580}$ This cannot compare, however, to Theocritus' wide-ranging use of the Doric future, ${ }^{581}$ of which there are no metrically guaranteed examples outside the Doric Idylls, but which are broadly distributed within that corpus (guaranteed 18 times, including the Epigrams). ${ }^{582}$ Considering its infrequent appearance in non-Sicilian literature as well as its use by Epicharmus, who was drawing on popular speech, ${ }^{583}$ it is probable that Theocritus' audience would have perceived the Doric future as an unliterary feature of popular Doric idiom, familiar from Syracusan authors who approximated such popular speech. ${ }^{584}$

Also significant is the fact that Theocritus does not merely allude to Doric futures he has seen in previous authors, but is most frequently the first or only author to use a word in this idiosyncratic form of the future. Molinos Tejada catalogues 23 instances of the Doric future in the genuine Doric Idylls and epigrams of Theocritus, ${ }^{585}$ from 19 different verbs, ${ }^{586}$ thus slightly

\footnotetext{
577 Magnien (1912) 378-380; Méndez Dosuna (2007) 449.

578 Olson (2002) lxxii; Magnien (1912) 383.

${ }^{579}$ Cassio (1997) 200-201; Magnien (1912) 380.

580 5.54, 116, 123; 6.127. See Cassio (1997) 201. For a list of all Doric futures in Callimachus, including nonmetrically guaranteed instances, see Magnien (1912) 382.

${ }^{581}$ Whereas Alcman utilized the Doric future only in the second person singular and plural, active and middle, as well as in the third person singular, active and middle, Theocritus shows no such limitations. Molinos Tejada (1990) 293. See also Page (1951) 123-125.

${ }^{582}$ Hunter (1996) 44 n. 173; Molinos Tejada (1990) 294-296. The Doric future is metrically guaranteed at Ids. 2.8; 3.38, 53; 4.39; 5.56, 103; 7.67, 95; 10.18; 14.55; 15.54, 99, 133, 135; 18.40 (x2), 46; Ep. 5.3. These are of instances Doric futures in the genuine Idylls found in Molinos Tejada's table (294-296), excluding the $3^{\text {rd }}$ person plural, which is not metrically guaranteed.

${ }^{583}$ Willi (2008), Chapter 5. Willi addresses the Doric future on pp. 128-129.

${ }^{584}$ See also Cassio (1997) 201; Magnien (1920) 116.

585 Molinos Tejada (1990) 294-296. This excludes singular active and second person singular middle, where only accent distinguishes Doric from non-Doric. A table on Molinos Tejada (1990) 10 includes singular active and second person singular middle forms. For a full list of Doric futures in Theocritus, see Magnien (1912) 382.

${ }^{586}$ Counting both $\dot{\pi} \pi \varepsilon \sigma \sigma \varepsilon \tilde{\imath} \tau \alpha \iota$ (5.56) and $\dot{\delta} \sigma \sigma \varepsilon \tilde{\tau} \tau \alpha \mathrm{l}$ (7.67) as a single verb.
} 
outnumbering the instances in previous Sicilian poets. ${ }^{587}$ According to a series of $T L G$ searches, Theocritus is the first or only author to use the Doric future for 13 out 19 of these verbs. ${ }^{588}$ The 6 exceptions are as follows.

i) The Doric future of $\beta \alpha$ ív occurs in a text roughly contemporary with Theocritus, though in a notably non-literary, Sicilian context: the compound $\kappa \alpha \tau \alpha \beta \alpha \sigma o v v \tau \tau \alpha$ is found at Archimedes 3.9.6 (Mugler). In a similarly non-literary context, we find $\sigma v \mu \beta \alpha \sigma \varepsilon i \tau \alpha \alpha$, at Ps. Archytas (29.8 Thesleff), a work of uncertain date, but possibly quite late, in imitation of the Tarentine philosopher Archytas. ${ }^{589}$ The form $\beta \alpha \sigma o v ̃ v \tau \alpha \iota$ is also attributed to the Letter of Cleobulus $\left(7^{\text {th }}-6^{\text {th }}\right.$ century BC) by Diogenes Laertius $1.93 .14\left(3^{\text {rd }}\right.$ century AD), but such letters are most often fictitious. ${ }^{590}$ In Theocritus, $\beta \alpha \sigma \varepsilon \tilde{v} \mu \alpha$ appears at 2.8.

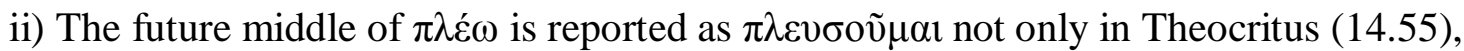
but also in Attic and Ionic (E.g. Hdt. 2.29, Thuc. 6.104; LSJ. Contracted future forms in $\pi \lambda \varepsilon v \sigma \varepsilon \tilde{-}$ are also Attic-Ionic [LSJ]). At Theocritus 14.55, however, Gow prints $\pi \lambda \varepsilon v \sigma \varepsilon \tilde{u} \mu \alpha \mathrm{l}$ based on manuscript evidence (WTr), which is a hapax.

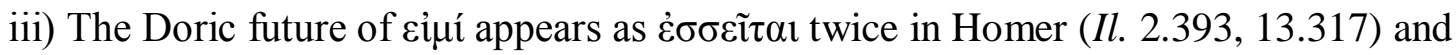
once by Hesiod (WD. 503). The verb then occurs in three Doric authors: Ps. Epicharmus (fr. 254.2 K. = 280 K.-A. [ex Alcimo]), the Pythagorean Philolaus, from Tarentum or Croton (3.2 D.-K.) and the Pythagorean Ps-Ecphantus (83.20, 21 Thesleff; the genuine Ecphantus was from

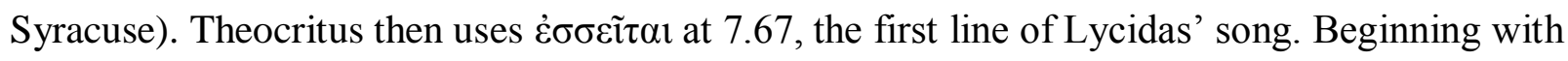
the Syracusan mathematician Archimedes, roughly contemporary with Theocritus, the form is

\footnotetext{
587 As compiled by Magnien (1912) 380-381.

${ }^{588}$ The Doric future of the $3^{\text {rd }}$ person plural is not guaranteed by meter (cf. Molinos Tejada [1990] 296). Of these there are five instances out of the 23 Doric futures in Molinos Tejada's table, at 4.26, 7.57, 7.71, 15.88 and Ep. 7.4. Accounting for these, 12 out of the 15 instances in which Theocritus is the first or only author to use a verb in the Doric future are metrically guaranteed.

${ }^{589}$ See Frede's article in Brill's New Pauly, s.v. "Archytas [2] Ps.-Archytas."

590 See Runia's article in Brill's New Pauly, s.v. "Diogenes [17]."
} 
used hundreds of times. The Doric future infinitive of eỉuí also appears in Sophron and Archimedes. ${ }^{591}$

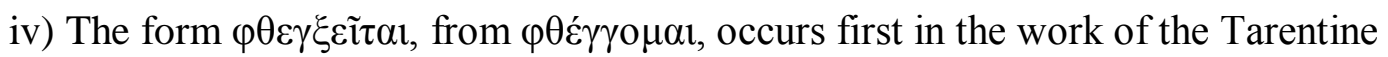
Pythagorean philosopher Archytas (1.63 D.-K.), and then in Theocritus (15.99. See also 14.22 for a the non-guaranteed $\varphi \theta \varepsilon \gamma \xi \tilde{\eta})$.

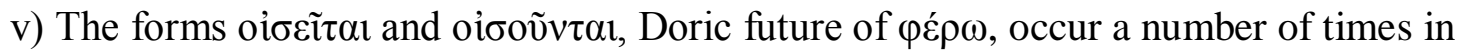
Archimedes, ${ }^{592}$ roughly contemporary with Theocritus, who uses oí $\sigma \tilde{v} \mu \varepsilon \varsigma$ at 15.133 (and see 1.3 for the non-guaranteed $\dot{\alpha} \pi 01 \sigma \tilde{\eta})$.

vi) The Doric future of $\chi \rho \alpha ́ \omega$, of which Theocritus uses a compound at 15.54,

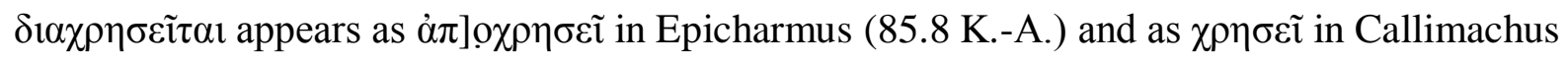
Hymn 5.126.

The rest of the Doric futures that occur in Idylls occur nowhere else prior to Theocritus, as far as can be determined using the search engines of the $T L G$ and Diogenes. ${ }^{593}$ Even the exceptions, however, have a strong Doric pedigree. To summarize, the Doric future is infrequent in previous literature; one place where it does occur with relative frequency is in Sicilian authors, including Epicharmus, who has been shown to write in popular Syracusan; Theocritus does not merely repeat Doric futures that he has found in previous authors, but is the first or only writer to use a verb in the Doric future in the majority of cases; all of this suggests that Theocritus' use of the Doric future is intended to evoke Doric vernacular speech.

The case grows stronger when we consider the epigraphic evidence. The Doric future is well attested epigraphically, in Sicily and elsewhere (see, e.g. IG XIV 645.109 and passim

\footnotetext{
${ }^{591}$ For the citations in this paragraph, see Magnien (1912) 381-382.

${ }^{592}$ E.g. De corporibus fluitantibus 3.16.2 and 3.17.9, respectively.

${ }^{593}$ Theoc. Ep. 7.4 contains the form $\tau \mu \alpha \sigma \varepsilon \varepsilon \tilde{v} \nu \imath$ (sometimes printed $\tau \mu \eta \sigma \varepsilon v \tilde{v \tau \imath}$ ), counted here among the verbs for which the Doric future occurs first or only in Theocritus. This epigram has sometimes been ascribed to Leonidas, but need not be (Gow [1952] vol. 2 527).
} 
(Heracleia); SEG 50 766.40, SEG 54745.24 [Cos]). And not only is it frequent in inscriptions, it also occurs in some of the same verbs found with Doric futures in the Idylls. Theocritus uses the Doric future of $\alpha \rho \chi \omega$ three times, more frequently than he does of any other verb: $\dot{\alpha} \rho \xi \varepsilon \tilde{v} \mu$ ' (7.95), $\alpha \rho \xi \varepsilon v ́ \mu \varepsilon \theta^{\prime}$ (15.135), $\alpha \rho \xi \varepsilon \tilde{u} \mu \alpha$ (Ep. 5.3), all of which are guaranteed by meter. The Doric future of $\ddot{\alpha} p \chi \omega$ is unattested elsewhere in Greek literature, but inscriptions have preserved a related form. Three inscriptions from Calymna, the Doric island directly to the north of Cos, roughly contemporary with Theocritus (300-200 B.C.), preserve the Doric future of vं $\pi \dot{\alpha} \rho \chi \omega$ :

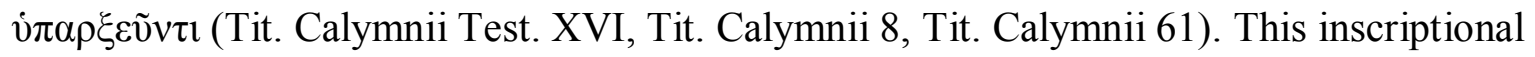
evidence and the fact that Theocritus utilizes so many examples of the Doric future that are unattested in prior Greek literature suggests that he is drawing on vernacular speech rather than previous literature or literary stereotype of Doric speech as a source to create his Kunstsprache.

\section{Perfect with present endings}

While Homer inflects a certain number of perfect verbs with present endings, ${ }^{594}$ vacillating between perfect and present endings for the perfect stems $\ddot{\alpha} v \omega \gamma \alpha$ and $\gamma \varepsilon \dot{\gamma} \gamma v v \alpha,{ }^{595}$ the ancient grammarians associate it especially with Sicily and Syracuse. ${ }^{596}$ Theocritus uses perfect stems with present endings only in the singular and the active infinitive; several of the poems in which the perfect stems take present endings also utilize normal perfect endings. ${ }^{597}$ This is no surprise, however, given that the Doric koine of the Entella tablets utilizes the form $\gamma \varepsilon \dot{\gamma} \gamma \varepsilon \varepsilon$ (3.11)

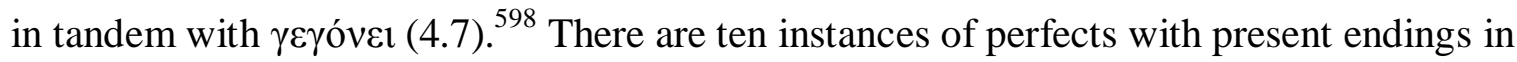

\footnotetext{
${ }^{594}$ Monro (1891) 30-31.

${ }^{595}$ For a fuller summary of perfect stems which utilize present endings, see Monro (1891) 30-31. See also Chantraine (1926) 193 and Molinos Tejada (1990) 302.

${ }^{596}$ Ahrens (1843) vol.2 328,n. 1 for the references to ancient grammarians. Although especially associated with Sicily and Syracuse, this phenomenon was not unknown in other Doric dialects. See Ahrens (1843) 328-330 for citations of examples from Doric literature. See also Molinos Tejada (1990) 302, with n. 399.

${ }_{597}$ Molinos Tejada (1990) 303.

${ }^{598}$ Molinos Tejada (1990) 303.
} 
Theocritus, all of which occur in the bucolics or Doric mimes. ${ }^{599}$ All but one of these examples come at line end, however, with the result that meter does not guarantee the necessity of reading a present ending in place of a perfect.

The single instance in which a perfect with a present ending does not occur at line end, however, is extremely instructive. Idyll 11 begins with Theocritus addressing his friend Nicias in propria persona:

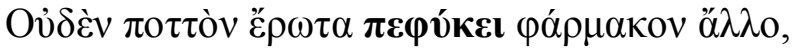

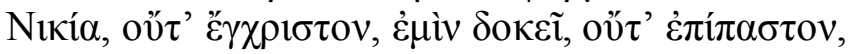

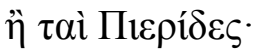

There is no other cure for love, Nicias, neither ointment nor plaster, it seems to me, besides the Muses.

Hunter has rightly noted that this first line of Idyll 11 is strongly marked and "stylistically

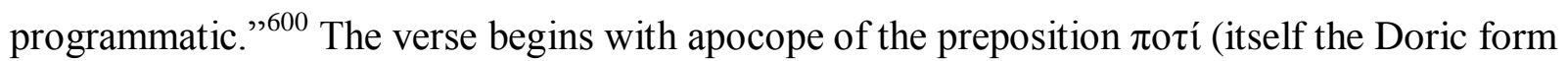
of $\left.\pi \rho \varsigma_{\varsigma}\right)$, a stylistic feature associated with low Doric speakers. ${ }^{601}$ The markedly Sicilian and Syracusan form of $\pi \varepsilon \varphi v ́ \kappa \varepsilon l$ then follows, at a point in the line that causes a violation of Naeke's Law (wordbreak after spondaic fourth foot). ${ }^{602}$ By violating a law characteristic of Callimachean practice ${ }^{603}$ in a prominent location and at the same time using markedly Doric and Sicilian forms, Theocritus separates himself from the norms of mainstream Hellenistic poetry and announces that Sicilian linguistic identity is part of his poetic program. It is all the more striking, therefore, that these programmatic statements are in propria persona. The epistolary opening of Idyll 11 explicitly mentions the joint heritage of the poet and Polyphemus—-both are from Sicily (11.7). As Hunter has noted, the use of similar language both by the poetic ego of Theocritus and the

\footnotetext{
${ }^{599}$ Molinos Tejada (1990) 304, with table.

${ }^{600}$ Hunter (1999) 225.

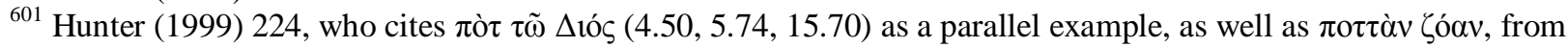
Epigram 18, a poem in honor of Epicharmus, which emphatically advertises the fact that it is written in Doric (1), and on behalf of the Syracusan people (5-6).

${ }^{602}$ Hunter (1999) 224 and 102.

${ }^{603}$ Hunter (1996) 29-30; (1999) 102. See also Hopkinson (1984) 51-55 for features of Callimachean hexameter.
} 
Cyclops in his subsequent monologue serves to create a "voice shared by both poet and Cyclops" ${ }^{604}$ (Idyll 11, for instance goes on to breech the law five more times, including in verses uttered by Polyphemus, e.g. 11.62) ${ }^{605}$ The basis for this shared voice is a common regional and

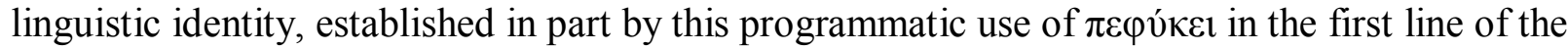
poem.

There are only two possible instances of $\pi \varepsilon \varphi v ́ \kappa \varepsilon l$ as a perfect with present endings prior to Theocritus, neither in Homer. ${ }^{606}$ The first of the two pre-Theocritus examples occurs in Lycophronides ( $P M G 843)$ :

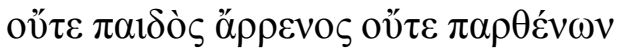

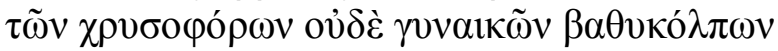

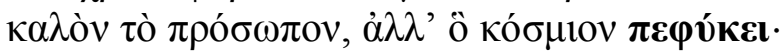

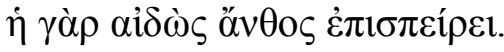

Neither of a boy, nor of a maid with golden ornaments, nor of a deep-robed woman is the countenance beautiful, unless it is moderate. For it is modesty that sows the blossom.

This instance, however, has been doubted by several editors, among them Page himself, who

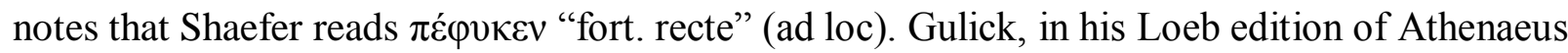

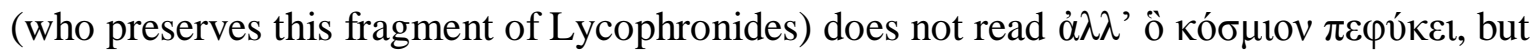

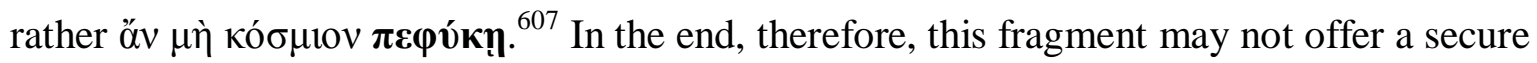
example of $\pi \varepsilon \varphi v ́ \kappa \varepsilon l$ as a perfect with a present ending. The other instance comes from Epicharmus, quoted by the Sicilian historian Alcimus (Müller FGH 7.86):

\footnotetext{
${ }^{604}$ Hunter (1999) 225.

${ }^{605}$ Gow (1952) vol. 2 28; Hunter (1999) 102.

${ }^{606}$ Although that form occurs several times in Homer and the Hymns (Il. 4.109, 4.483, 21.352; Od. 5.63, 5.238, $5.241,7.114 ; H H 2.100$.), it is always as an unaugmented pluperfect. The form $\pi \varepsilon \varphi v ́ \kappa \varepsilon 1$ also occurs at Hesiod (145.17 M.-W.), but also appears there to be an unaugmented pluperfect. Monro (1891) 30-31 does not include $\varphi v ́ \omega$ or $\pi \varepsilon \varphi v ́ \kappa \varepsilon 1$ on his list of "chief instances" of perfects with present endings. Od. 7.114 would be the best candidate for an example of a perfect with present ending, but Heubeck et al. (1988) 329 decides that $\pi \varepsilon \varphi v ́ \kappa \varepsilon 1$ there is an example of the unaugmented pluperfect (though admits the possibility that it is a present ending). See also Chantraine (1958) vol. 1428.

${ }^{607}$ Gulick (1950) vi. 46; Athenaeus 13.564b.
} 


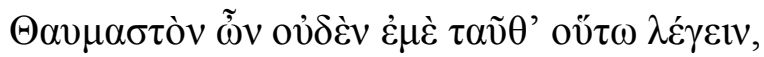

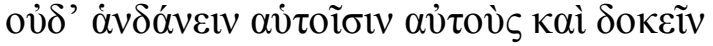

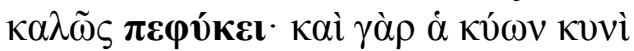

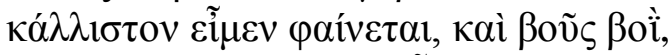

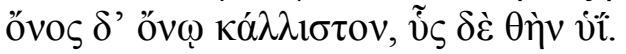

Therefore it is nothing wondrous for me to say such things, nor for them to please and seem beautiful to their own kind. For to a dog, it is a dog that seems most beautiful, and an ox to an ox, an ass to an ass, a pig to a pig are surely most beautiful.

The above reading is not followed by other editors: Kaibel (173.3 = K.-A. 279.3) reads $\pi \varepsilon \varphi v ́ \kappa \varepsilon ı v$, as does Jacoby (560.6.26), putting Müller's reading in doubt. This variant reading of the active infinitive in place of the finite form would still be significant, however, in that it too would be a present ending on a perfect stem. In any case, the only secure example from previous literature appears in the text of a Sicilian historian quoting the Syracusan poet Epicharmus. The

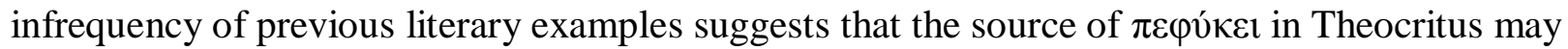
not be prior literary tradition. Rather, Theocritus (and Epicharmus) may be directly imitating Sicilian vernacular. It is notable, too, that perfects with present endings are entirely absent from the Doric poems of the bucolic poets who followed Theocritus, ${ }^{608}$ which may suggest that the Sicilian poet depended upon a tradition to which he had close ties, but the others did not. What is certain is that Theocritus uses the perfect with a present ending $\pi \varepsilon \varphi v ́ \kappa \varepsilon 1$ three times, when it only occurs once in all of previous literary tradition, if we exclude Lycophronides. ${ }^{609}$ To a contemporary audience, therefore, the word would have been a strongly marked as a non-literary, Sicilian vernacular form.

\footnotetext{
${ }^{608}$ Mollinos Tejada (1990) 303-304.

${ }^{609}$ The manuscript tradition of Theocritus is extremely consistent with regard to perfects with present endings (Mollinos Tejada [1990] 303). The mss. are, for the most part, in agreement about the three instances of $\pi \varepsilon \varphi v ́ \kappa \varepsilon 1:$ at 5.33 , the tradition is unanimous; at 5.93, a single $13^{\text {th }}$ century ms. $(\mathrm{K})$ proposes to read $\varphi v \lambda \alpha ́ \sigma \sigma \varepsilon 1$ in place of $\pi \varepsilon \varphi v ́ \kappa \varepsilon 1$; in the case of $11.1, \mathrm{~K}$ and $\mathrm{Va}\left(15^{\text {th }}\right.$ cent.) both read $-\eta$.
} 
Recent scholarship supports the notion that ancient audiences would have perceived the perfect with present endings as Sicilian vernacular form. This type of word-ending was not among the "banal Doric features" which made up the Doric koina ${ }^{610}$ Instead, it is one of a small number of features which "are not common to all Doric dialects," which gave Sicilian Doric a distinctive character and has been found in inscriptions at Entella, Centuripa and Akragas. ${ }^{611}$ Willi, who has recently concluded that Epicharmus composed in a popular Syracusan idiom, counts the perfect with present endings among the features of Sicilian morphology to be found in that poet, as, indeed did Herodian. ${ }^{612}$ If the perfect with present endings was ever used in literature outside of Sicily, it must have been extremely rare. A survey of relevant sources reveals no citations of the form in non-Sicilian sources, even in the Doric experiments of Theocritus' contemporaries, though its presence is more widespread in dialectal inscriptions. ${ }^{613}$ Since Theocritus uses a metrically guaranteed instance of this vernacular form to make a point about his own vernacular identity, and in light of the strong evidence that the perfect with a present ending was perceived in antiquity as a feature of Sicilian Greek, it is not reckless to extend this conclusion to the remaining, non-metrically guaranteed instances. These endings occur only in the genuine Doric Idylls of Theocritus and in none of the subsequent bucolic authors, whether Ps. Theocritus or otherwise. They have a wide distribution in the Doric Idylls of Theocritus. The ten instances are spread over seven Idylls; of the bucolics, they are absent only

\footnotetext{
${ }^{610}$ Mimbrera (2012) 231.

${ }^{611}$ Mimbrera (2012) 231. Although this form does appear in a limited number of other Doric vernaculars, it was perceived as Sicilian, and may indeed have originated at Akragas (Mimbrera [2012] 232-233).

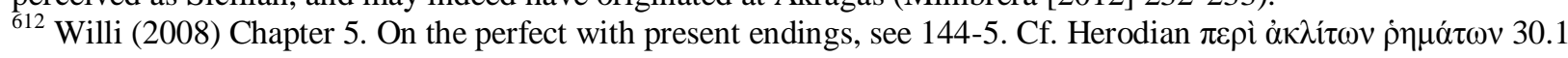
(Hilgard).

${ }^{613}$ Ahrens (1843) vol. 2 328-329; Magnien (1920) 117; Chantraine (1926) 191-194; Buck (1955) 118; Willi (2008) 144-145. Such forms are not mentioned in commentaries on Callimachus' Hymns 5 and 6, Bulloch (1985) and Hopkinson (1984) respectively, nor in Sens' account of Posidippus' Doric (2004) 67-73. Nor does the perfect with present endings occur in Isyllus, as edited by Kolde (2003). The related form í $\sigma \alpha \mu$ (a present verb conjugated on the root of i $\sigma \alpha \alpha^{2} \tau \imath, 3^{\text {rd }}$ person perfect plural of oĩ $\delta \alpha$ ), which Hesychius cites as a Syracusan usage, is found in Theocritus and Syracusan authors but slightly more broadly as well, including Pindar (Nem. 7.14; Pyth. 3.29), an epigram of Nossis (A.P. 7.718) and the letter of Periander (Diog. Laert. 1.99). On this form see Ahrens (1843) vol. 2345 with $\mathrm{n}$. 1; Magnien (1920) 119; Molinos Tejada (1990) 291-292.
} 
from Idylls 3 and $6 .^{614}$ The poem with the greatest number of perfects with present endings is Idyll 5, with three $(28,33,93)$. This concentration may be significant, since that Idyll takes place not in Sicily, but in Southern Italy. Given that it is Sicily that is more closely associated with this dialectical feature, its use in Idyll 5 may be akin to the use of short -ŏ $\varsigma$ plural accusative endings in that poem: the point may not be to exactly mimic a real epichoric dialect, but to create a fictional Kunstsprache that is plausibly popular and local in color.

\section{$\pi \rho \tilde{\alpha} v, \pi \rho \omega ́ \alpha v$ and $\pi \rho o ́ \alpha v$}

The temporal adverb $\pi \rho o ́ \alpha v$ appears four times in Theocritus (4.60, 5.4, 15.15 [twice]). Theocritus also has $\pi \rho \omega ́ \alpha v$ at 14.5 , and $\pi \rho \tilde{\alpha} v(2.115,3.28,32,5.81,132,6.35,7.51,10.16)$.

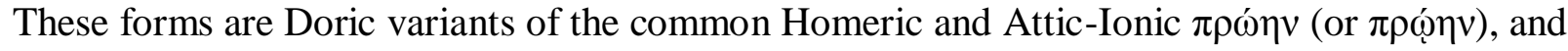
they occur exclusively in the bucolics and Doric mimes. The Ionic form $\pi \rho \tilde{\omega} \nu$ ( $\pi \rho \tilde{\varphi} v)$ is also attested in the literary tradition, at Callimachus fr. 219 (Pf.) and Herodas 5.62. Neither the codices nor the papyri of Theocritus ever read $\pi \rho \tilde{\omega} \nu(\pi \rho \tilde{\omega} \nu)$ in place of $\pi \rho \tilde{\alpha} v$, despite the fact that these forms are metrically equivalent. Nor does $\pi \rho \omega ́ \eta v$ (or $\pi \rho \varphi ̂ ́ \eta v)$ appear in Theocritus. Each of the three Doric variants, however, is supported by papyrological evidence. The Antinoae Papyrus $\left(\mathrm{P}_{3}\right)$ attests $\pi \rho \omega ́ \alpha v$ at $14.5, \pi \rho o ́ \alpha v \ldots \pi \rho o \alpha v$ in 15.15 (the second of which is also found in $\mathrm{P}_{4}$ ), and $\pi \rho \tilde{\alpha} \nu$ at $2.115 .^{615}$

As with the other features discussed so far, the distribution of the various forms of this Doric adverb demonstrates that Theocritus consciously divided the Idylls into various linguistic groups. ${ }^{616}$ The fact that the Doric forms of the adverb only appear in Doric poems conforms to

\footnotetext{
${ }^{614}$ See the table on Molinos Tejada (1990) 304.

615 On these variants, see Molinos Tejada (1990) 100-101.

${ }^{616}$ See Hunter (1996) 38-45 on other evidence for this claim.
} 
our expectations about the text of Theocritus. But can we draw any further significance from Theocritus' use of this form?

To begin with, it is noteworthy that none of these Doric variants, neither $\pi \rho$ ó $\alpha \nu, \pi \rho \tilde{\alpha} v$ nor $\pi \rho \omega ́ \alpha v$, appears in extant Greek literature before Theocritus. Even though the forms $\pi \rho \omega ́ \eta v$ and $\pi \rho \omega ́ \eta v ~ a p p e a r$ frequently in Homer and Attic authors, the absence of Doric variants before Theocritus suggests that an ancient audience would have interpreted $\pi \rho{ }^{\alpha} \alpha \nu, \pi \rho \tilde{\alpha} \nu$ and $\pi \rho \omega ́ \alpha v$ not only as Doric, but as markedly non-literary, although it may simply be the case that the relevant exempla have been lost. The presence of $\pi \rho \cos _{\alpha}, \pi \rho \tilde{\alpha} \nu$ and $\pi \rho \omega \dot{\alpha} \alpha$ in the Idylls raises another question: even if Theocritus' audience would likely have interpreted the Doric variants as markedly non-literary, did the poet invent the forms himself or was he drawing on vernacular speech?

The truth of the matter is that we have no evidence upon which to base a hypothesis, save what we can find in Theocritus himself. Theocritus certainly uses the forms with a regularity to suggest that they are not novel (13x in all), despite not occurring in previous literature. It is hard to believe that the poet would use a neologism with such regularity, which may suggest that he was utilizing a common element of everyday speech, rather than making it up from scratch, even if there is no way of confirming this line of reasoning. Perhaps more persuasive is the fact that Theocritus very clearly calls attention of his use of $\pi \rho$ ó $\alpha$. At 15.15, the poet uses the form twice in single line. Not only does this form occur nowhere besides Theocritus in all of Greek literature, but it is perhaps the most markedly Doric of the three variants that appear in the Idylls. The variant $\pi \rho \omega ́ \alpha v$ is easily explained as Doric retention of $-\bar{\alpha}$ for $-\eta$, and thus not all that striking; $\pi \rho \tilde{\alpha} v$ finds an analogous form in the Ionic $\pi \rho \tilde{\omega} v$, and is again not metrically distinct from it (though, as mentioned, the manuscript tradition never reports $\pi \rho \tilde{\omega} v$ 
in place of $\pi \rho \tilde{\alpha} v){ }^{617}$ The form $\pi \rho{ }^{\alpha} \alpha v$, however, not only retains the $-\alpha$, but is metrically distinct

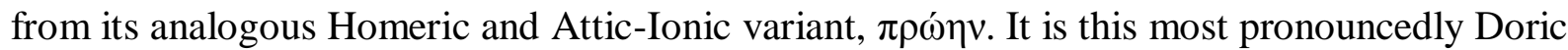
form that Theocritus makes Praxinoa repeat twice in the same line at 15.15, in a highly conversational context between two (distinctly non-literary) Syracusan women:

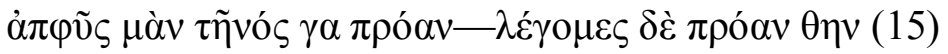

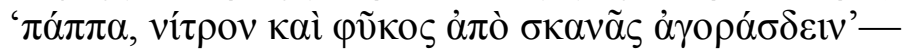

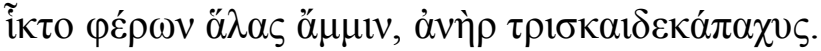

Still, that daddy the other day - it was only the other day I said to him, 'Pa, go and get some soda and ruddle at the stall', and he brought me back salt, and he a great giant of a man. (trans. Gow)

The two other instances of $\pi \rho{ }^{\alpha} \alpha \nu$ that occur in the Idylls are also in conversational circumstances (4.60 and 5.4). It may be that, at Idyll 15.15, Theocritus is attempting to draw his reader's attention to his use of a markedly vernacular Doric variant. The vernacular and colloquial quality of 15.15 is heightened by the presence of the word $\alpha \pi \varphi \tilde{v} \varsigma$ ("papa"), which does not occur anywhere else in Greek literary texts, save for twice in Idyll 15 itself (15.13 and 15.14). Thus, we have a triple repetition of an otherwise unknown and seemingly colloquial word, which comes shortly before the double repetition of the form $\pi \rho$ ó $\alpha v$, also unknown outside of Theocritus. The poet certainly seems to be using repetition to draw our attention to the his use of novel and vernacular vocabulary.

There is a tantalizing reading of lines $15.15-16$ that would go a long way towards supporting this theory. The text that modern editors print, including Gow, is that offered above. As Gow notes, however, "the traditional reading in the remainder of the sentence is $\lambda \dot{\varepsilon} \gamma o \mu \varepsilon \varsigma \delta \dot{\varepsilon}$

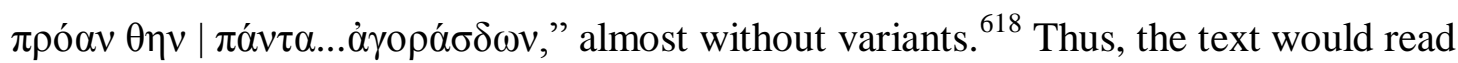

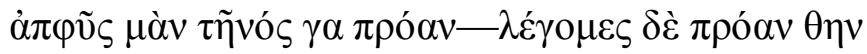

\footnotetext{
${ }^{617}$ Theocritus' use of $\pi \rho \tilde{\alpha} v$ in place of $\pi \rho \tilde{\omega} v$ is analogous to the variation between West Greek $\pi \rho \tilde{\alpha} \tau o \zeta$ as compared to Attic-Ionic $\pi \rho \tilde{\omega} \tau$.. . See Buck (1955) 114.1.

${ }^{618}$ Gow (1952) vol. 2270.
} 


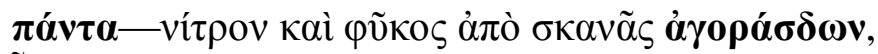

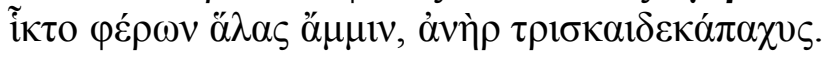

Still, that daddy the other day — we call everything 'the other day' — went to get some soda and ruddle at the stall, and he brought me back salt, and he a great giant of a man. (trans. Gow, with modifications, some of them Gow's [ad loc])

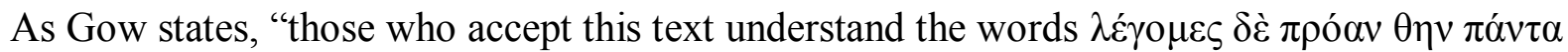
(which $\Sigma$ ignore) to be a parenthesis commenting on the excessive frequency of the adverb $\pi \rho \alpha_{\alpha \nu}$ in common speech." ${ }^{619}$ I suggest, following Cholmeley, ${ }^{620}$ that we should accept reading best supported by the manuscripts in this case, and understand it as yet another instance of selfconscious linguistic commentary on the part of Theocritus (cf. the comments above on $\pi \varepsilon \varphi v ́ \kappa \varepsilon \iota$ at 11.1). Such linguistic self-awareness would be particularly in keeping with Idyll 15, in which Praxinoa will subsequently have a heated exchange on the subject of Doric vernacular speech (15.87-95).

$\tau \varepsilon \tilde{v} \varsigma$

In most dialects (including Attic-Ionic, Arcadian, and Lesbian) the second person singular nominative pronoun begins with $\sigma-$, "after the analogy of other cases where it comes regularly from $* t w$-...for example acc. $\sigma \varepsilon \varepsilon(\sigma \varepsilon)<* t w e ́ . " 621$ In Boeotian and Doric, on the contrary, it was the dental stop $\tau-$, the expected outcome in the nominative $(* t u ́>\tau u ́)$, that spread to the other cases by analogy. ${ }^{622}$ Theocritus very much favors second person singular pronouns in $\tau$ - in the bucolics and Doric mimes. Editors tend to print only a single instance of the second person singular pronoun beginning with a sibilant in these poems, where the singer appears to be

\footnotetext{
${ }^{619}$ Gow (1952) vol. 2270.

${ }^{620}$ Cholmeley (1919) 294-295.

${ }^{621}$ Sihler (1995) 367.1.

${ }^{622}$ Molinos Tejada (1990) 244-245.
} 
aiming for a more serious tone $(\sigma \varepsilon \dot{\varepsilon} \theta \varepsilon v, 4.38) .{ }^{623}$ As Hunter notes, $\sigma \varepsilon \dot{\theta} \theta \varepsilon v$ is here "presumably...a mark of (mock) high-style in a song. ${ }^{624}$ We will be concerned only with the genitive case of the second person singular pronoun, which comes in three forms: $\tau \varepsilon \tilde{v}(5.19,7.25), \tau \varepsilon \tilde{v} \varsigma(2.126,5.39$, $10.36,11.52,55)$ and $\tau \varepsilon o \tilde{} \varsigma(11.25,18.41)$. Since $\tau \varepsilon \tilde{u} \varsigma$ is metrically guaranteed at 2.126 and 11.55 , that form is of most value here. ${ }^{625}$

According to a search of the $T L G$, the pronoun $\tau \varepsilon \tilde{v} \varsigma$ appears only twice in all Greek literature before Theocritus, once in the Boeotian of Corinna (fr. $24 P M G$, which Apollonius Dyscolus [75.7] cites as a Boeotian form) and once in Epicharmus (fr. 85 K.= 74 K.-A.). Since the form is nearly absent from earlier literature, the use of $\tau \varepsilon \tilde{v} \varsigma$ on five occasions by our poet is therefore likely to represent the conscious elevation of a vernacular, non-literary form into the literary sphere. ${ }^{626}$ Given that one of the two previous uses of $\tau \varepsilon \tilde{v} \varsigma$ occurs in Epicharmus (fr. 85 $\mathrm{K} .=74 \mathrm{~K} . \mathrm{-A}$, in a line strongly marked as Doric by the use of the pronoun $\pi$ o $\tau$ í [with apocope]

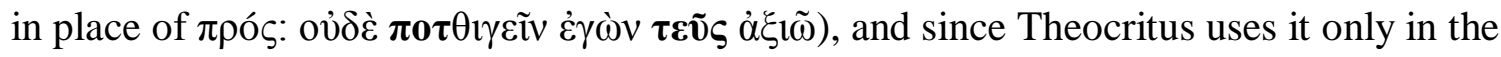
bucolics or in Doric mime, it is probably the case that this pronoun would have been strongly marked as Doric to the audience of the Idylls. Moreover, the fact that this rare form also appears in Epicharmus, who, as Willi argues, wrote in every-day Syracusan, ${ }^{627}$ suggests that Theocritus intends to echo popular speech with the use of this pronoun.

There may be epigraphic evidence for $\tau \varepsilon \tilde{u} \varsigma$, as well. SEG 341005 is an inscription from Metapontum, during the $2^{\text {nd }}$ half of the $4^{\text {th }}$ century B.C., in honor of a dead athlete. As published in 1984, the inscription reads:

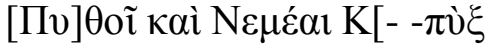

\footnotetext{
${ }^{623}$ Molinos Tejada (1999) 244-248, and see 246 on the topic of Id. 4.38.

${ }^{624}$ Hunter (1999) 139.

${ }^{625}$ Hunter (1999) 210; Molinos Tejada (1999) 246; Gow (1952) vol. 258.

${ }^{626}$ Compare this with $\tau \varepsilon \tilde{v}$, which is much more common.

${ }^{627}$ Willi (2008) Chapter 5. On $\tau \varepsilon \tilde{v} \varsigma$ see Willi (2008) 137-139.
} 
$\dot{\varepsilon} \sigma \tau \varepsilon] \varphi \alpha \nu \omega ́ \theta \eta \nu$

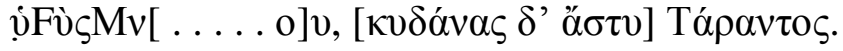

At Pytho and Nemea...

I was crowned

[ ], [having honored the city] of Tarentum.

However, Lo Porto ${ }^{628}$ has proposed to read $[\tau] \varepsilon \tilde{v} \varsigma \mu v[\tilde{\alpha} \mu \alpha$ in place of $\mathfrak{y} F \hat{\jmath} \varsigma M v$. If we were to follow Lo Porto, we would have additional evidence that Theocritus was drawing upon actual Doric vernacular speech in his use of $\tau \varepsilon \tilde{v} \varsigma$, rather than upon a previous literary stereotype of the same. $^{629}$

\section{Words with non-literary, Doric coloring}

Having completed our survey of metrically guaranteed, unliterary Doric features from the Idylls, we now move on to a selection of individual lexemes. While by no means exhaustive, they provide enough of a sample to conclude that the poet uses a number of strikingly unliterary words in an effort to evoke Doric vernacular speech.

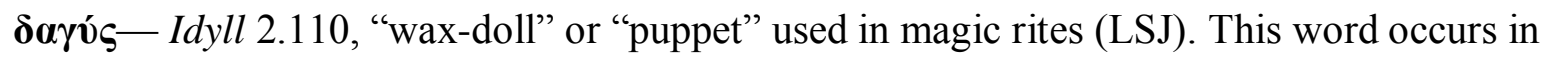
Greek literary texts only once before Theocritus, in the work of the Doric poet Erinna (401.21 $S H$ ), who was most likely from Telos in the middle of the $4^{\text {th }}$ century (Robbins s.v. "Erinna" in Brill's New Pauly). Although otherwise unused in literature, $\delta \alpha \gamma u ́ \varsigma$ does appear in a Sicilian inscription. SEG 261116 is a fragment of a leaden defixio from the first half of the $5^{\text {th }}$ century $\mathrm{BC}$, found at Selinous, which reads $\delta \alpha \gamma v$ or $\delta \alpha \gamma o$. It is probably no coincidence, then, that Theocritus employs this word in his second $I d y l l$, which depicts the spurned lover Simaetha as she casts a binding spell on her beloved.

${ }^{628}$ Lo Porto (1967) 95-96, with note 307.

${ }^{629}$ See, however, Moretti (1983) 495-497, whose text SEG 341005 follows. 


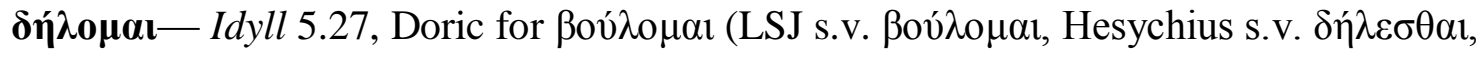
$\left.\dot{\varepsilon} \delta \eta \lambda o_{\mu} \mu \alpha v\right)$. The scholia cite $\delta \eta ́ \lambda o \mu \alpha \iota$ as a specifically Doric word (see $\Sigma$ and Gow ad 5.27). The sole instance of this word in Theocritus occurs in a highly colloquial and proverbial context and

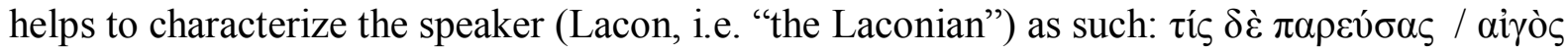

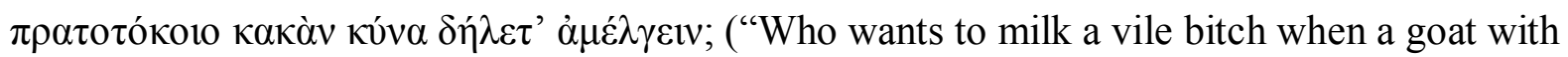

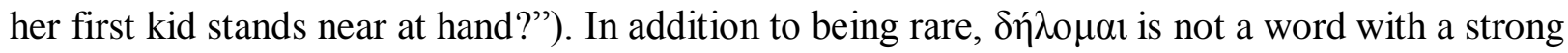
literary pedigree prior to Theocritus. It occurs, for instance, in the Doric fragments of the philosopher Crito (Thesleff 109.5), as well as in Ps. Hippodamus (Thesleff 102.1), and in the Pythagorean works of the Doric philosopher Ps. Timaeus (Thesleff 207.3). Plutarch also reports

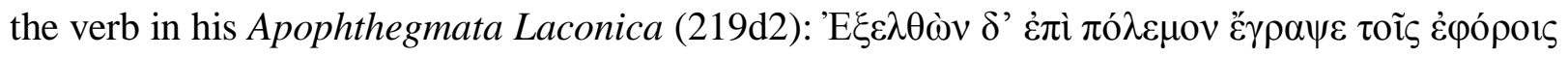

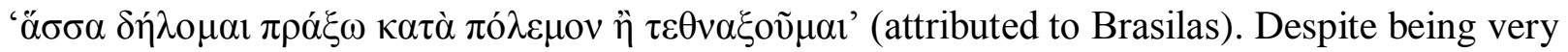

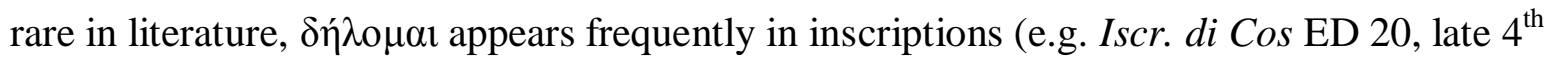
century BC from Cos; SEG 48 1094, SEG 51 1050, SEG 54 745, $3^{\text {rd }}$ century BC from Cos; cf. $\delta \varepsilon \dot{\lambda} \lambda \varepsilon \tau \alpha 1, I G$ IX $1^{2} 3: 718,5^{\text {th }}$ century Locris).

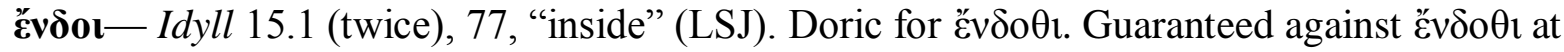
15.1. Gow prints an alternative form at 15.55 , ह̌v $\delta$ ov, which is supported by $\mathrm{P}_{3 .}{ }^{630}$ The adverb

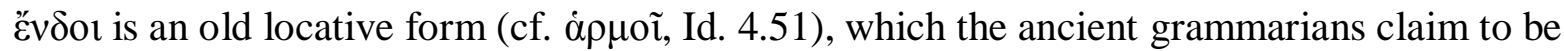
Sicilian or Syracusan (Et. M. 663.28, Eustath. 722.62), perhaps on the basis of its use in Theocritus. ${ }^{631}$ While certainly Doric, ह̌vסoı was in fact used outside of Sicily, as an inscription from the first half of the $4^{\text {th }}$ century BC at Epidaurus testifies $\left(I G \mathrm{IV}^{2}, 1102\right)$. The word also appears in a Cyrenaean inscription from 325-300 BC (SEG 50 1638.18). This word appears very

\footnotetext{
${ }^{630}$ Gow (1952) vol. 2266.

${ }^{631}$ Gow (1952) vol. 2 266, Molinos Tejada (1990) 339.
} 
infrequently in literature apart from Theocritus. The author of the Dissoi Logoi $\left(\mathrm{a} 4^{\text {th }}\right.$ century Doric philosophical text) uses it at fr. 2.6 (D.-K.). Callimachus uses it in his Doric Hymn to Demeter (76). ${ }^{632}$ The word also appears in an anonymous literary fragment preserved by Apollonius Dyscolus (Supplementum Hellenisticum 1005). Apart from these instances, the word appears elsewhere among Greek literary authors only in Theocritus. The triple use of $\varepsilon^{\prime} v \delta o t$ in Idyll 15-one more time than in the rest of Greek literature - is certainly marked against the backdrop of previous tradition. As has been the case in other examples, Theocritus takes care to highlight his use of an unusual Doric word. It occurs at both line beginning and end at 15.1, and

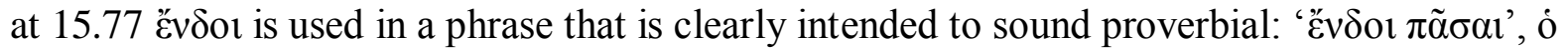

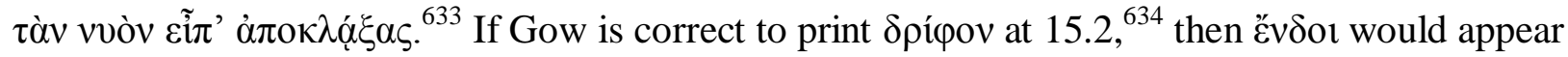
here in close proximity with another Doric near-hapax: $\delta$ pípo $\varsigma$ otherwise occurs only in Sophron (fr. 10 K. = 10 K.-A.).

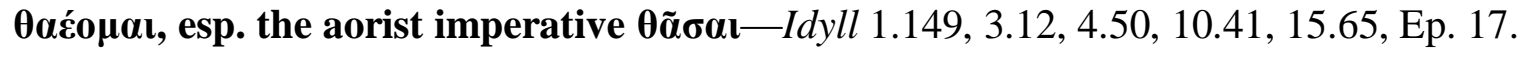

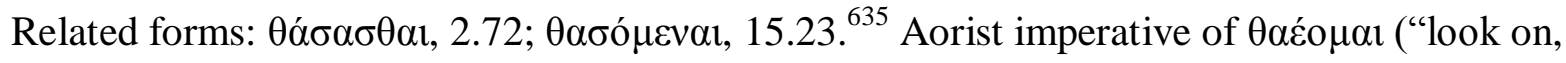
gaze at, behold" [LSJ]), in which $\tilde{\alpha}<-\alpha \varepsilon$ (LSJ s.v. * $\theta \alpha ́ o \mu \alpha l)$. In Idyll 22, Theocritus uses the

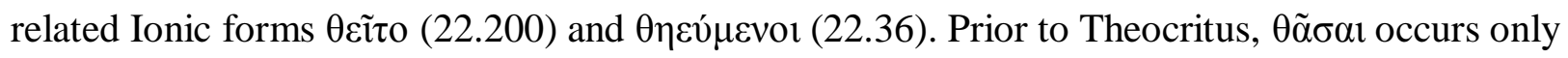
in Epicharmus (114 K. = 114 K.-A.) and Sophron (26, 32 K. = 25, 31 K.-A.). The distribution of $\theta \tilde{\alpha} \sigma \alpha \mathrm{l}$ in Theocritus aligns well with its Doric coloration, ${ }^{636}$ and represents a dramatic uptick in its frequency compared to past authors. Epigraphic evidence attests to the use of words related to

\footnotetext{
${ }^{632}$ Hopkinson (1984) 44, who attributes Callimachus' choice of Doric for this poem "to the Hellenistic fondness for dialectical experiments."

${ }^{63}$ See Gow ad loc.

${ }^{634}$ See Gow ad loc.

${ }^{635}$ Gow (1952) vol. 232.

${ }^{636}$ See Gow (1952) vol. 2 531, however, on the strange use of $\theta \tilde{\alpha} \sigma \alpha \iota$ in Ep. 17, a poem with Doric coloration dedicated to Anacreon of the Ionic island Teos.
} 


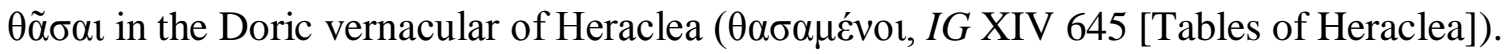
Aristophanes also uses the related imperative form $\theta \tilde{\alpha} \sigma \theta \varepsilon$ at Acharnians 770 , where it is used to parody the Megarian manner of speech. Phaenias (11.25 Wehrli) preserves the related Doric

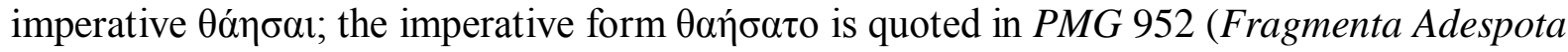
$34)$.

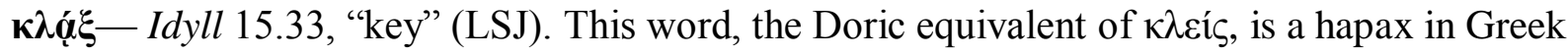
literature. While certainly not a literary word, $\kappa \lambda \hat{\alpha} \xi \xi$ is not uncommon in inscriptions (including $H G K 14,\left[3^{\text {rd }}\right.$ century BC Cos], SEG $5076\left[2^{\text {nd }}-1^{\text {st }}\right.$ cent. BC Cos], $I G$ IV $^{2} 102,110$, al. $\left[4^{\text {th }}\right.$ century BC Epidaurus]). On words of this form in Theocritus, see Molinos Tejada (1990) 300.

$\lambda \tilde{\boldsymbol{\omega}}$-Idyll 1.12 (twice), 4.14, 5.21, 5.64, 11.56, Ep. 5.1. Unlike the other vocabulary items discussed so far, $\lambda \tilde{\omega}$ has a strong literary presence even before the Idylls, and the pre-Theocritean examples of this well-known Doric synonym for $\theta \dot{z} \lambda \omega$ (LSJ) are too numerous to name. However, the literary uses of $\lambda \tilde{\omega}$ are of a very particular sort: “ $\lambda \tilde{\eta} v$...is completely absent from epic and high lyric, but is one of the most persistent features of literary Doric at 'lower' levels. ${ }^{" 637}$ The word is used not only by Doric authors like Epicharmus, but also by Aristophanes to characterize the parlance of Doric speakers (see LSJ for examples of both). The verb occurs not only in literature, but in numerous inscriptions as well (see LSJ for a sampling). Theocritus uses this word only in his bucolic Idylls and Ep. 5, as is suitable to its Doric coloration. It is clear that $\lambda \tilde{\omega}$ is a word that was part of realistic vernacular speech as well as literary stereotype of the

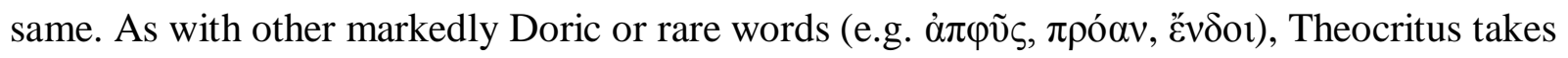
care to highlight the appearance of $\lambda \tilde{\omega}$ by means of emphatic repetition:

${ }^{637}$ Hunter (1999) 73. 


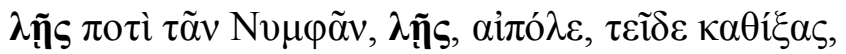

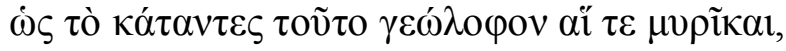

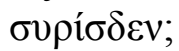

Would you, in the name of the Nymphs, would you play the syrinx, goatherd, having sat down here, where the steep hill and the tamarisks are? (1.12-14)

The verb in question appears at line beginning and directly following the caesura, directly preceding another pause, in a verse that also contains the Doric locative $\tau \varepsilon \tilde{i} \delta \varepsilon$ and bucolic dieresis. Note as well the hyperbaton separating $\lambda \tilde{n} \varsigma$ from its complement, $\sigma 0 \rho i ́ \sigma \delta \varepsilon v$, which is itself a programmatic word, of a markedly Doric form (- $-\varepsilon v$ infinitive ending). Just as the poet has used much rarer Doric forms to emphasize the connection of the bucolic Idylls and Doric mimes to vernacular language, he does so again with the much more recognizable word $\lambda \tilde{\omega}$.

\section{CONCLUSION}

Before discussing the implications of this survey, I offer a summary of our metrically guaranteed findings (table 1) and lexical data (table 2).

Table 1: Metrically Guaranteed Doric Word-forms

\begin{tabular}{|c|c|c|c|c|}
\hline $\begin{array}{l}\text { Doric } \\
\text { Feature }\end{array}$ & $\begin{array}{l}\text { Occurrences in } \\
\text { Idylls }\end{array}$ & $\begin{array}{l}\text { Occurrences in } \\
\text { other Doric } \\
\text { Authors }\end{array}$ & $\begin{array}{l}\text { Doric Inscriptional } \\
\text { Evidence }\end{array}$ & $\begin{array}{l}\text { Occurrences in } \\
\text { Non-Doric } \\
\text { Authors }\end{array}$ \\
\hline $\begin{array}{l}\text { Plural } \\
\text { acc. } \\
\text { endings } \\
\text { in }-\breve{s} \varsigma\end{array}$ & $\begin{array}{l}\text { Guaranteed at } \\
1.90,4.11,5.84, \\
106,109,112, \\
114 .\end{array}$ & $\begin{array}{l}\text { Epicharmus } 170.13 \\
\text { (K.) = Ps. } \\
\text { Epicharmus ( } 276.7 \\
\text { K.-A.). }\end{array}$ & $\begin{array}{l}\text { Inscriptions of Cyrene, } \\
\text { Thera and Cos, e.g. } \\
\text { SEG } 20716.25 \\
\text { (Cyrene); IG XII.3 } \\
\text { 330.13, } 15 \text { and passim } \\
\text { (Thera); SEG 51 } \\
\text { 1050.15, } 18 \text { (Cos); } \\
\text { Segre Iscr. di Cos ED } \\
\text { 206.8. Also found in } \\
\text { Arcadian and } \\
\text { Thessalian inscriptions } \\
\text { (Buck [1955] 68). }\end{array}$ & $\begin{array}{l}\text { Hesiod, Shield } \\
(302) .\end{array}$ \\
\hline $\begin{array}{l}\text { Doric } \\
\text { Futures }\end{array}$ & $\begin{array}{l}\text { Guaranteed at } I d s \text {. } \\
2.8 ; 3.38,53 \text {; }\end{array}$ & $\begin{array}{l}\text { Frequent in } \\
\text { Syracusan authors }\end{array}$ & $\begin{array}{l}\text { Very frequent in Doric } \\
\text { inscriptions (see table }\end{array}$ & $\begin{array}{l}\text { Limited number } \\
\text { in the middle }\end{array}$ \\
\hline
\end{tabular}




\begin{tabular}{|c|c|c|c|c|}
\hline & $\begin{array}{l}\text { 4.39; 5.56, 103; } \\
7.67,95 ; 10.18 ; \\
\text { 14.55; } 15.54,99, \\
133,135 ; 18.40 \\
(\times 2), 46 ; E p .5 .3 . \\
\text { Non-guaranteed } \\
\text { passim in Doric } \\
\text { Idylls. } \\
\text { Never guaranteed } \\
\text { outside Doric } \\
\text { Idylls and } \\
\text { Epigrams. }\end{array}$ & $\begin{array}{l}\text { (see table on } \\
\text { Magnien [1912] } \\
\text { 380-383). } \\
\text { Also guaranteed } 4 \\
\text { times in Doric } \\
\text { Hymns of } \\
\text { Callimachus: 5.54, } \\
\text { 116, 123; 6.127. } \\
\text { (For non- } \\
\text { guaranteed } \\
\text { instances in } \\
\text { Callimachus, see } \\
\text { Magnien [1912] } \\
\text { 382). } \\
\text { Absent from Doric } \\
\text { lyric authors } \\
\text { (Cassio [1997] } \\
\text { 200-201). }\end{array}$ & $\begin{array}{l}\text { Magnien [1912] 384- } \\
\text { 396). }\end{array}$ & $\begin{array}{l}\text { voice in Homer } \\
\text { and Attic authors } \\
\text { (see table on } \\
\text { Magnien [1912] } \\
\text { 378-380). }\end{array}$ \\
\hline $\begin{array}{l}\text { Perfect } \\
\text { with } \\
\text { present } \\
\text { endings }\end{array}$ & $\begin{array}{l}\text { Guaranteed at } \\
11.1, \text { where it is } \\
\text { used for } \\
\text { programmatic } \\
\text { purpose. } \\
\text { Non-guaranteed at } \\
1.102,4.7,40, \\
5.28,33,93,10.1 \text {, } \\
15.58 .\end{array}$ & $\begin{array}{l}\text { Associated } \\
\text { especially with } \\
\text { Sicily, and may } \\
\text { have originated } \\
\text { there (Mimbrera } \\
\text { [2012] 232-3). } \\
\text { Apparently absent } \\
\text { from Doric authors } \\
\text { outside of Sicily. } \\
\text { See above, pg. } 32 \\
\text { with n. } 127 .\end{array}$ & $\begin{array}{l}\text { Inscriptions in Entella, } \\
\text { Centuripa and } \\
\text { Akragas, Sicily } \\
\text { (Mimbrera [2012] 232- } \\
\text { 3), as well as Rhodes, } \\
\text { Cnidus, Carpathos, } \\
\text { Phocis, Delphi, } \\
\text { Epidaurus (Buck } \\
\text { [1955] 118). }\end{array}$ & $\begin{array}{l}\text { Limited number } \\
\text { in Homer } \\
\text { (Monro [1891] } \\
\text { 30-1). }\end{array}$ \\
\hline$\pi \rho o ́ \alpha \nu$ & $\begin{array}{l}\text { Guaranteed at } \\
4.60,5.4,15.15 \\
\text { (twice). }\end{array}$ & None. & None. & None. \\
\hline$\tau \varepsilon \tilde{v} \zeta$ & $\begin{array}{l}\text { Guaranteed at } \\
2.126,11.55 . \\
\text { Non-Guaranteed } \\
\text { at } 5.39,10.36 \text {, } \\
11.52 .\end{array}$ & $\begin{array}{l}\text { Epicharmus fr. } 85 \\
\text { K. = } 74 \text { K.-A. }\end{array}$ & $\begin{array}{l}\text { SEG } 34 \text { 1005? (See Lo } \\
\text { Porto [1967] 95-6, with } \\
\text { note 307). }\end{array}$ & $\begin{array}{l}\text { Corinna fr. } 24 \\
(P M G) .\end{array}$ \\
\hline
\end{tabular}

Table 2: Select Doric Lexemes 


\begin{tabular}{|c|c|c|c|c|}
\hline $\begin{array}{l}\text { Doric } \\
\text { Lexeme }\end{array}$ & $\begin{array}{l}\text { Occurrences } \\
\text { in Idylls }\end{array}$ & $\begin{array}{l}\text { Occurrences in } \\
\text { Other Doric Authors }\end{array}$ & $\begin{array}{l}\text { Doric Inscriptional } \\
\text { Evidence }\end{array}$ & $\begin{array}{l}\text { Occurrences in } \\
\text { Non-Doric } \\
\text { Authors }\end{array}$ \\
\hline $\begin{array}{l}\delta \alpha \gamma u ́ \varsigma \\
\text { ("wax-doll" } \\
\text { or "puppet") }\end{array}$ & 2.110 . & Erinna (401.21 SH). & $\begin{array}{l}\text { SEG } 261116, \\
\text { defixio from } \\
\text { Selinous, Sicily. }\end{array}$ & None. \\
\hline 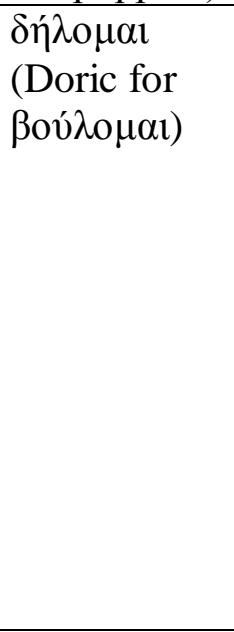 & 5.27. & $\begin{array}{l}\text { Rare in literary works; } \\
\text { occasionally found in } \\
\text { Philosophical texts: } \\
\text { Crito } 109.5 \\
\text { (Thesleff), Ps. } \\
\text { Hippodamus } 102.1 \\
\text { (Thesleff), and in the } \\
\text { Pythagorean works of } \\
\text { the Doric philosopher } \\
\text { Ps. Timaeus } 207.3 \\
\text { (Thesleff), Plutarch } \\
\text { Apoph. Laconica } \\
\text { 219d2. }\end{array}$ & $\begin{array}{l}\text { Frequent in } \\
\text { inscriptions, e.g. } \\
\text { Iscr. di Cos ED 20, } \\
\text { late } 4^{\text {th }} \text { century BC } \\
\text { from Cos; } S E G 48 \\
1094, S E G 511050, \\
S E G 54745,3^{\text {rd }} \\
\text { century BC from } \\
\text { Cos; cf. } \delta \varepsilon i ́ \lambda \varepsilon \tau \alpha, I G \\
\text { IX } 1^{2} 3: 718,5^{\text {th }} \\
\text { century Locris. }\end{array}$ & None. \\
\hline 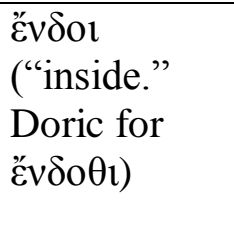 & 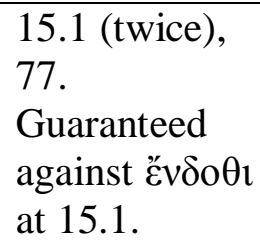 & $\begin{array}{l}\text { Dissoi Logoi fr. } 2.6 \\
\text { (D.-K.), Callimachus } \\
\text { Hymn 6.76. }\end{array}$ & $\begin{array}{l}I G \mathrm{IV}^{2}, 1102 \\
\text { (Epidaurus), SEG } 50 \\
1638.18 \text { (Cyrene). }\end{array}$ & None. \\
\hline 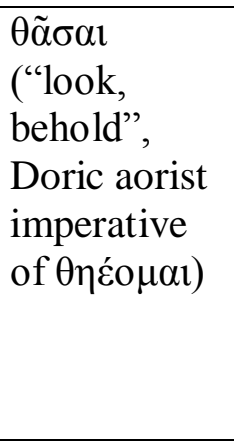 & $\begin{array}{l}1.149,3.12, \\
4.50,10.41, \\
15.65 \text { and } E p . \\
17 .\end{array}$ & $\begin{array}{l}\text { Epicharmus } 114 \text { (K.= } \\
114 \text { K.-A.), Sophron } \\
26,32 \text { (K. =25, } 31 \text { K.- } \\
\text { A.). }\end{array}$ & 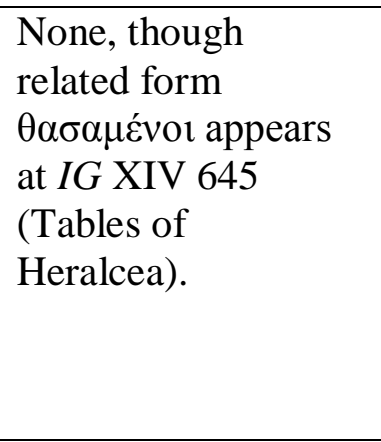 & $\begin{array}{l}\text { None, though } \\
\text { Aristophanes has } \\
\theta \tilde{\alpha} \sigma \theta \varepsilon \text { at } \\
\text { Acharnians } 770, \\
\text { where it is used } \\
\text { to parody the } \\
\text { Megarian } \\
\text { manner of } \\
\text { speech. }\end{array}$ \\
\hline 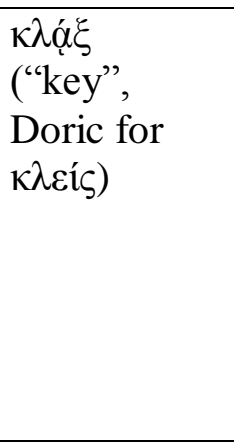 & 15.33 & None & $\begin{array}{l}\text { Occurs in } \\
\text { inscriptions, e.g. } \\
H G K 14,\left(3^{\text {rd }}\right. \\
\text { century BC Cos }) \text {, } \\
S E G 5076\left(2^{\text {nd }}-1^{\text {st }}\right. \\
\text { cent. BC Cos }), I G \\
\text { IV }^{2} 102,110, \text { al. }\left(4^{\text {th }}\right. \\
\text { century BC } \\
\text { Epidaurus }) .\end{array}$ & None \\
\hline $\begin{array}{l}\lambda \tilde{\omega} \text { (Doric } \\
\text { for } \theta \dot{\varepsilon} \lambda \omega)\end{array}$ & $\begin{array}{l}1.12 \text { (twice), } \\
4.14,5.21, \\
5.64,11.56 \\
\text { and } E p .5 .1\end{array}$ & $\begin{array}{l}\text { Frequent in Doric } \\
\text { authors and parodies } \\
\text { of Doric speech. Not } \\
\text { found in high epic or }\end{array}$ & $\begin{array}{l}\text { Frequent in Doric } \\
\text { inscriptions. See } \\
\text { LSJ. }\end{array}$ & $\begin{array}{l}\text { Frequent in } \\
\text { parodies of Doric } \\
\text { speech. }\end{array}$ \\
\hline
\end{tabular}


The language of the Doric Idylls is clearly a Kunstsprache, cobbled together from features not characteristic of a single historical dialect (e.g. perfect with present endings are associated especially with Sicily and Syracuse, while short -ŏ $\varsigma$ accusatives were not used there). Molinos Tejada and Abennes are surely right to argue that Theocritus creates an artificial literary language, while Ruijgh's conjecture that the language of Idyll 15 was an actual dialect, namely, the speech of immigrants to Alexandria from Cyrene, is hardly supported by the evidence. But this conclusion was hardly in doubt. More important is to consider the methodological, social and cultural implications of particular details from Theocritus' Kunstsprache, and their cumulative effect on the reader.

We will begin with a methodological conclusion. Based on the above analysis of strongly marked, metrically guaranteed word-forms and lexemes, we are on a firmer ground to interpret such features of Theocritean Doric when they are not metrically guaranteed. Idyll 5 serves as a good illustration, since it utilizes all of the word-forms analyzed in this chapter. ${ }^{638}$ First of all, on the basis of the metrically guaranteed examples, there are better grounds to accept even nonguaranteed readings of similar features, in Idyll 5 and elsewhere. Considering only the guaranteed instances of forms discussed here, Idyll 5 has a strongly marked, unliterary, vernacular Doric texture. ${ }^{639}$ But the effect increases drastically when we take non-guaranteed features into account. In the first line, for instance, there is the Doric pronoun $\tau \tilde{\eta} v o v$ in place of

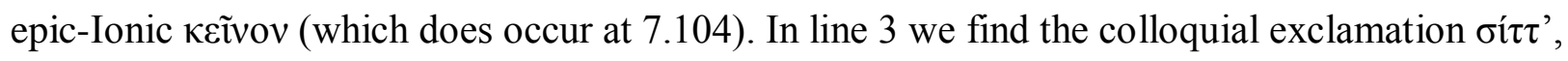

\footnotetext{
${ }^{638}$ Perfect with present ending (28, 33, 93; none guaranteed); $\tau \varepsilon \tilde{v} \varsigma$ (39; not metrically guaranteed); short -ŏ $\varsigma$ accusatives (84, 106, 109, 112, 114; all guaranteed); $\pi \rho o ́ \alpha v ~(4 ;$ guaranteed); Doric future (guaranteed at 5.56). ${ }^{639}$ E.g. Short -ŏ $\varsigma$ accusatives $(84,106,109,112,114$; all guaranteed); $\pi \rho o ́ \alpha v$ (4; guaranteed); Doric future (guaranteed at 5.56).
} 


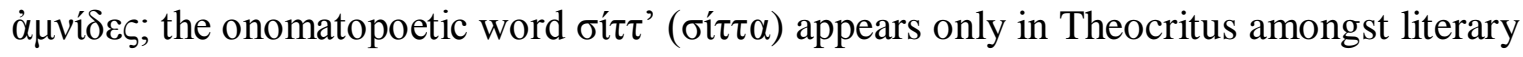

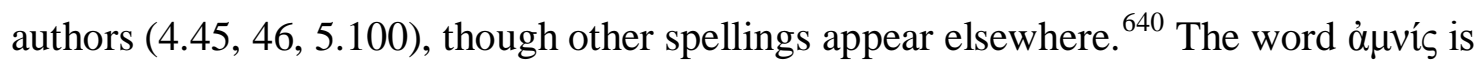
apparently unique to Idyll 5 (used again at 139 ). ${ }^{641}$ Directly following this expression comes $\dot{\varepsilon} \sigma 0 \rho \eta \tilde{\tau} \varepsilon$ at line end, exhibiting a Doric contraction $(\alpha+\varepsilon>\eta$ rather than Attic-Ionic $\bar{\alpha}) .{ }^{642}$ Line four offers severe Doric $\delta \tilde{\omega} \lambda \varepsilon$ for $\delta$ oṽ $\lambda \varepsilon .{ }^{643}$ Such a detailed reading of unliterary and strongly marked dialect features could continue throughout the entirety of Idyll 5. Given the number of metrically guaranteed popular and dialect forms in Idyll 5 it is safe to credit other similar, but non-guaranteed features, except in cases where there is evidence to the contrary. The cumulative effect of such features is to evoke a strongly marked, popular, unliterary regional speech. A similar analysis could be extended to the rest of the Doric Idylls, although some Idylls will be less marked than Idyll 5, which is one of the most 'realistic' of the corpus. ${ }^{644}$

Next, consider the ideological implications of Theocritean Doric. The word-forms and lexemes analyzed above are strongly marked Doricisms with connections, in most instances, to vernacular, epichoric speech. Such forms stand out, therefore, against the contemporary backdrop of the pan-Hellenic, epic-Ionic koine, the official language of the Ptolemies and the other successor courts. But this opposition between Theocritus' Doric and koine should not be understood only as a contrast between Doric vs. non-Doric speech; there is an additional contrast between more local vs. more universal or standardized language. Theocritus employs certain word-forms that are not generalized features of Doric, but isolated to particular regions or perceived as such (for example, plural acc. endings in -ŏ $\zeta$ and perfect with present endings). Even the Doric future, though a generalized feature of unliterary Doric, may well have been

\footnotetext{
${ }^{640}$ See $\psi i ́ \tau \tau \alpha$ and $\psi v ́ \tau \tau \alpha$, LSJ.

${ }^{641}$ See Gow (1952) vol. 2 116-117.

${ }^{642}$ Buck (1955) 37.

${ }^{643}$ See Abbenes (1996) 3.

${ }^{644}$ Crane (1988) 107-122, esp. 110.
} 
perceived by a literary audience as Syracusan, the only place it appeared with any frequency in literature.

Theocritus draws attention to the ideological implications of his strongly marked Doric on a number of occasions. In addition to the Praxinoa episode in Idyll 15, with which this chapter began, two programmatic passages utilize word-forms highlighted here. First, the metrically

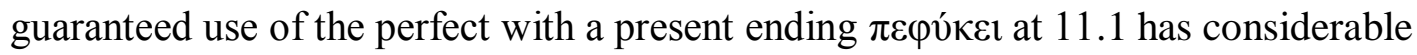
implications. The perfect with present ending was not a universal feature of Doric, but associated especially with Sicily and Syracuse. Theocritus employs this highly regionalized word-form, in a verse that breaks with contemporary metrical norms, writing in the first person to highlight the fact that he and the Cyclops Polyphemus both come from Sicily (11.7). Dialect is used here to make a point about regional identity. Something similar may be said about the double use of $\pi \rho o ́ \alpha v$ at 15.15 . There, if our conjectured reading is correct, the Syracusan Praxinoa selfconsciously refers to her repeated use of the strongly marked Doric adverb (in a passage that uses other markedly non-literary, Doric features). Such heightened linguistic self-consciousness is certainly appropriate in a woman who will go on in the same Idyll to argue with an Alexandrian stranger about her use of the Doric dialect.

Theocritus' Doric is also exceptional with regard to contemporary and previous Doric authors. The short -ŏ $\varsigma$ accusatives could hardly be called a feature of literary Doric prior to Theocritus, yet the Idylls contain 7 metrically guaranteed examples, all in circumstances relating to the rustic world, as if to emphasize the popular connotations of the word-form. Even the fragments of Epicharmus contain only a single instance of this ending. It is such small dialectal details like this that sharply distinguish Theocritus' Doric from that of his contemporaries: short -ŏ $\varsigma$ accusatives would not be at home in the language of Posidippus, and are absent from 
Alcman, Callimachus and Isyllus. The same goes for $\tau \varepsilon \tilde{v} \varsigma$, a form that is virtually absent from literature prior to Theocritus, save for one appearance in the Sicilian poet Epicharmus (fr. $85 \mathrm{~K}$. $=74$ K.-A.) and a second in Corinna (fr. $24 P M G$ ). Despite the absence of $\tau \varepsilon \tilde{c} \varsigma$ from even the relatively severe Doric of Alcman, as from contemporaries like Isyllus, Callimachus and Posidippus, Theocritus uses it five times, twice guaranteed. ${ }^{645}$ Theocritus' use of the perfect with present endings also distinguishes him from other Doric poets and from the dialect experiments of his contemporaries; it does not appear in Callimachus, Posidippus or Alcman, but only in Syracusan authors. The only word-form analyzed here that appears in the work of another contemporary poet is the Doric future, guaranteed four times in the Doric hymns of Callimachus. ${ }^{646}$ When the Doric future appears elsewhere in literature, however, it is mainly used by Sicilian authors, including Epicharmus, who used a Sicilian vernacular. It would likely have been marked as an unliterary Doric form by readers of the Idylls, where it is distributed broadly, 18 metrically guaranteed instances. ${ }^{647}$ This large number of guaranteed Doric futures is especially striking in light of its absence from lyric poetry, including previous Doric authors like Pindar, Alcman, Bacchylides, Simonides, Stesichorus or Ibycus.

If Willi is correct that Epicharmus used Syracusan vernacular as his literary language, then Theocritus' literary Doric certainly does not come as close to that of the earlier poet in approximating vernacular Doric. Epicharmus, after all, appears to depict the actual language of Syracuse and shows relatively little polymorphism — it is not a Kunstsprache $-{ }^{648}$ whereas Theocritus combines Doric forms that never occurred together in actual use, and these appear right alongside Homeric features. Theocritus is in some ways even more radical, however, and

\footnotetext{
${ }^{645} 2.126,5.39,10.36,11.52,55$. Guaranteed at 2.126 and 11.55 .

${ }^{646} 5.54,116,123 ; 6.127$.

${ }^{647}$ Ids. $2.8 ; 3.38,53 ; 4.39 ; 5.56,103 ; 7.67,95 ; 10.18 ; 14.55 ; 15.54,99,133,135 ; 18.40$ (x2), 46; Ep. 5.3.

${ }^{648}$ Willi (2008) 5.8.1.
} 
his Doric more startling, than his Syracusan forebear. The juxtaposition of disparate elements gives power to Theocritus' language. It has been pointed out that much of the poet's novelty comes from contrast of treating pastoral subject in epic meter. ${ }^{649}$ A similar point may be made about Theocritus' use of dialect: power comes from seeing Doric features where we are not accustomed to expect them. ${ }^{650}$ We are conditioned to expect vernacular speech in a comic setting. Yet Theocritus takes very regionalized, unliterary word-forms and adapts them to a high, literary setting. The same may be said, to an extent, about some of Theocritus' contemporaries and predecessors. Callimachus also adapts Doric to hexameter verse, as does Isyllus; and of course Doric was a familiar literary language of lyric poetry, and remained so for poets like Posidippus. Where Theocritus diverges from his contemporaries and predecessors, however, is in the strongly marked quality of his Doric. As has been demonstrated, several of the forms studied here are absent or virtually absent from even Doric literature. It is the fact that Theocritus incorporates such strongly marked, regionalized Doric forms into his literary hexameter poetry that makes his dialect stand out as radical, whether against a contemporary backdrop or in comparison with Epicharmus.

To further consider the dialect of Theocritus in its contemporary setting, the inclusion of highly regionalized and unliterary Doric features of the Idylls also creates an ideological contrast with the Doric associated with the Ptolemaic court. Doric may have been the prestige language of the Ptolemies, but none of the word-forms discussed here appears in the court poetry of Posidippus; they are certainly more appropriate to the shepherds and city-dwellers of the Idylls than to Macedonian royalty. Theocritus likely drew this distinction himself: the Encomium of Ptolemy (Id. 17), after all, does not belong to the same linguistic group as the bucolics and Doric

\footnotetext{
${ }^{649}$ Fantuzzi and Hunter (2004) 138-141.
}

${ }^{650}$ Willi (2012) 279-280. 
mimes. Although Idyll 17 does contain a light admixture of Doric, all of the word-forms analyzed here are absent, as are a number of other noticeably Doric forms. ${ }^{651}$

To summarize these conclusions, the analysis of strongly marked Doric features should give us more confidence in marked Doric readings where meter is no aid. Moreover, we may also be more confident in understanding the purpose of those forms, namely, to create a fictional, literary Kunstsprache that evokes highly regionalized Doric vernacular speech, without literally reproducing any one local dialect. This same motive should likely be extended to cover many of the uncommon or un-poetic words of the Doric Idylls, the many instances of proverbial language, as well as types of references to popular songs, tales and traditions- but that is too great a topic to cover here. ${ }^{652}$ The effect of Theocritus' Doric Kunstsprache is to create ideological oppositions between Doric and non-Doric, local and pan-Hellenic, vernacular and elite or literary.

The dialect of the bucolics and urban mimes, then, is very much appropriate to themes and characters of those poems, many of whom are representations of just the sort of cultural tensions that Theocritean Doric highlights. We have already seen that the Syracusan women of Idyll 15 emblemize the complex cultural niche that the Doric Idylls occupy. On the one hand, they are cultural outsiders, Syracusans abroad in a foreign city, Doric speakers in an increasingly koine world. At the same time, like the Idylls themselves, Praxinoa takes pride her own cultural status. Her broad speech is nothing odd to her ears, but natural to a Syracusan, a regional affiliation with a dignified pedigree stretching back to Corinth and the Peloponnese, as she argues. Anyway, the Ptolemies themselves boast to be Doric speakers from the Peloponnese! Even if Praxinoa never mentions it, the Doric origin of the Ptolemaic royal house is a subtext of

\footnotetext{
${ }^{651}$ Hunter (2003) 55-56.

${ }^{652}$ See, for example, Cipolla (1979); Horowski (1973); Petropoulos (1959); Merkelbach (1956); Caberghs (1944); Di Mino (1931).
} 
Idyll 15, whose setting is a Ptolemaic festival. The tensions embodied by Theocritean Doric are likewise fitting for the ballad of Daphnis. Just as the dialect of the bucolics is a medley of popular and highly regionalized elements, Daphnis a figure drawn from popular cult, of deep local significance to Sicily, much more idiosyncratic than Adonis, his pan-Hellenic counterpart. A similar case may be made for Polyphemus, who is the hero not only of the Homeric epics, but of folktale, too. The Cyclops of Idylls 11 and 6 is on the one hand a monstrous caricature of the most rustic and popular element of human society; as a denizen of Doric Sicily, he is very far, both culturally and geographically, from the cosmopolis of Alexandria. As is appropriate to that cultural station, he sings in an unpolished meter and in the idiosyncratic dialect of the Idylls. On the other hand, Theocritus claims Polyphemus as his own countryman, no longer at the outskirts, but at the very center of the poet's cultural milieu. Likewise, Theocritus' appropriation, preservation and celebration of bucolic's popular, non-literary language in hexameter poetry lends this idiosyncratic dialect, perhaps monstrous from an outside perspective, seriousness and dignity. 


\section{Conclusion}

The three topics addressed here-Daphnis, Polyphemus and Theocritus' Doric Kunstsprache - are the core of the bucolic world. Daphnis and Polyphemus constitute the two most important mythological figures of the bucolic Idylls, the tragic and comic poles of the mode. Daphnis in particular is the embodiment of this type of poetry, its first singer and subject. I have argued in detail that Theocritus utilizes traditions about Daphnis and Polyphemus drawn from popular Sicilian lore, and that he does so in a way that makes each of these figures an emblem of local Sicilian identity and symbolic of the whole of Theocritean bucolic. Likewise, I have shown that Theocritus' Doric utilizes a combination of epichoric and sub-literary forms that characterizes all of the bucolic Idylls.

Daphnis, Polyphemus and Theocritean Doric are thus integral to the meaning of the bucolic Idylls; their connection to popular culture is not a mere literary pose, but draws on contemporary vernacular traditions. In each of these three subjects, moreover, popular culture is related to local identity. In Chapter 1, I demonstrate that Daphnis and Theocritean bucolic most likely emerged from Sicilian popular religious festivals to Artemis, which were brought to Sicily by colonists from the Peloponnese. Although previous authors have suggested that the legendary founder and first singer of bucolic poetry is related to Near Eastern paredroi, Daphnis' most important cultural associations in the context of bucolic are to the staunchly Doric Sicilian milieu in which Theocritus most likely encountered him. Chapter 2 investigates the implications of this theory of origins for the meaning of Idyll 1 and explores the 'poetics of locale,' which that poem inaugurates. The first Idyll's connection to festival performance and Sicilian popular cult is argued in greater detail; Daphnis' specifically local connotations are shown to be essential to the

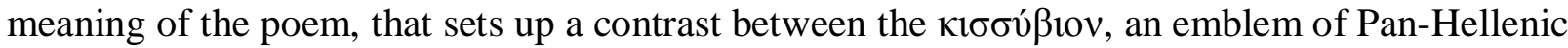


epic, and the ballad of a Sicilian hero. In Chapter 3, I examine Polyphemus (Idylls 11 and 6) and show how Theocritus re-appropriates this Pan-Hellenic figure for Sicily by reforming his character and positioning him at the narrative and geographic center of his poetry. Moreover, departing from previous literary depictions in favor of a version with local Sicilian roots Theocritus leaves open the possibility that Polyphemus successfully wins Galatea. Finally, Chapter 4 demonstrates that the dialect of the bucolic Idylls, like Daphnis and the Cyclops, serves as a means of reflecting on local and popular Doric identity. Although the dialect of the bucolics is an artificial literary language, it employs historical, unliterary and regional wordforms, often drawn from epichoric Doric dialects. In contrast to epic language and the increasingly standard Attic-Ionic koine, even though it does not accurately portray the dialect of any particular Doric region, the language of the bucolic Idylls evokes vernacular Doric speech.

To be sure, the connection between Theocritus' bucolic Idylls and popular culture is not surprising. The subject matter of the Idylls is drawn from an idealized version of everyday life, and owes a debt in this respect to the genre of mime, which was defined by its attention to nonliterary characters and subjects. According to the scholia (¿.Arg.), Idylls 2 and 15 borrowed heavily from the literary mimes of Theocritus' fellow Syracusan, Sophron, and a number of the bucolic poems also bear the hallmarks of that genre. In addition to the literary mimes of poets like Sophron, Theocritus and Herondas, there existed a body of popular mimes that come down to us in fragmentary form. ${ }^{653}$ The bucolics also profess their allegiance, real or imagined, to a number of popular forms besides mime. The songs of Theocritus' idealized herders pose as real herding songs. Milon's song in Idyll 10 seems to root itself in a popular threnodic ritual and Simichidas' song in Idyll 7 incorporates realistic magic rites. ${ }^{654}$ There is precedent, too, for

${ }^{653}$ On Theocritus and mime see Fantuzzi and Hunter (2004) 133-141;Hunter (1999) 4-5; Hunter (1996) 110-123.

${ }^{654}$ On Idyll 10, see above, 97-98. On magic in Idyll 7, see Hunter (1999)184-185. 
Theocritus' use of contemporary epichoric Doric forms in the bucolics and urban mimes in Epicharmus, a fellow Sicilian who used the Syracusan dialect in his comedies. ${ }^{655}$ Nor is Theocritus alone in his interest in mixing elite forms with popular themes. Hellenistic poets were fascinated by the tension between high and low, a gulf made more dramatic by the transformation of poetry from something performed into literature that had to be read. ${ }^{656}$

Through my detailed study, I hope to have confirmed the impression of Theocritus as a poet with roots in contemporary vernacular tradition and to have demonstrated that the consideration of popular culture in the Idylls discussed here cannot be separated from the issue of local identity. Theocritus' fellow Sicilian Polyphemus, himself a pastoral poet, becomes a means of negotiating competing literary interests, the literary canon on the one hand, and local folklore on the other. Since Daphnis arises within the ambit of popular cult specific to Doric Sicily, Theocritus' placement of this figure at the center of the bucolic stage, in competition with the

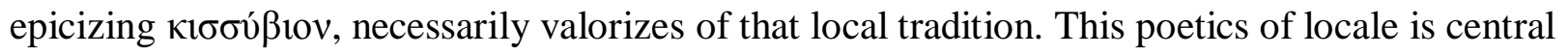
to Theocritus' pastoral project.

But what does this link between bucolic and local identity mean for the poetic mode as a whole? As I suggested in my introductory reading of Idyll 7, bucolic poetry takes place at a thematic and geographical remove from the cosmopolis. Bucolic is fundamentally a poetry of the margins. The sense of being at a distance from traditional conceptions of a cultural center permeates every one of the bucolic Idylls: the characters are lower-class, marginal figures and the locus amoenus is an oasis in a deserted countryside. In addition to Simichidas' journey into rustic isolation (Id. 7), several other striking images of cultural distance come to mind. In Idyll 11, Polyphemus' isolation is palpable as he wishes (not, ironically, in vain) for some stranger to

\footnotetext{
${ }^{655}$ Willi (2008) 5.1-5.8.

${ }^{656}$ See, e.g. Hunter (1996) 110-111.
} 
come and visit his island, to teach him how to swim. It is almost as if Polyphemus is beckoning from afar to the mainstream literary canon. In Idyll 4, a poem not treated here, the herders Battus and Corydon talk while the latter pastures the cows of his master, who has gone to compete at the Olympic Games. This vision of two herders left behind with the cattle in South Italy while their social better attends a major Pan-Hellenic festival is a fitting image for bucolic poetry.

Although Idyll 7 features a cosmopolitan city-dweller venturing into the bucolic realm, the reverse scenario - a herder venturing into the city — never arises in the surviving poems of Theocritus. This is of a piece with bucolic's fundamental self-position at the margins. Idyll 15, however, does present us with two bourgeois Syracusan women abroad in Alexandria. Gorgo and Praxinoa may not fare as badly in the city as would a goatherd, but they nonetheless experience some rough treatment at the hands of the locals when they are abused by a stranger for speaking in their native Syracusan dialect. Andreas Willi has seen these women as emblematic of the poet and his Doric Idylls, trying to "blend in" but failing to hide their outsider status. Yet Willi also claims that we must not import into the interpretation of Idyll 15 our modern view of Syracuse as a cultural backwater in comparison to Alexandria. He suggests that, when the poem was written, Syracuse would still have been contending for cultural superiority with Alexandria. Both Syracuse and Alexandria, after all, were peripheral relative to mainland Greece, so Gorgo and Praxinoa would have had as much reason for cultural pride as the Alexandrian stranger. ${ }^{657}$ Although Willi is certainly right to emphasize that the Syracusan women would have had plenty of reason to take pride in Sicilian cultural achievements, we ought rather to focus on the women's position at the margins. It is striking that Theocritus did not choose to depict a pair of Alexandrian women insecurely asserting their cultural self-worth to a

${ }^{657}$ Willi (2012) 280-284. 
stranger on the streets of Syracuse. The point is that the Syracusan women do not conform to the new shared culture, the koinon, of which Alexandria was the chief representative.

Despite Theocritus' acknowledgement of the bucolic world's marginality vis-à-vis the political and cultural center of Alexandria, his new poetic mode nonetheless refuses to conform. The poet refigures Polyphemus as his countryman and relocates him from the barbaric periphery to the narrative center of Idylls 11 and 6. But this shift of perspectives is only effective if we knowingly acknowledge that there is another version of this story, a more canonical version, relative to which bucolic stands at the periphery. This double awareness permeates the dialect of bucolic as well as its most emblematic figures, Daphnis and Polyphemus, and is part of what makes the bucolic Idylls themselves so novel and cosmopolitan. By striking a pose of inferiority with regard to the cultural dominance of the cosmopolis and its koinon, Theocritus achieves an independent perspective from which to valorize the local and popular culture of Sicily. The result, paradoxically, of this ostensibly inferior posture, which favors the local hero Daphnis as its champion and claims the monster Polyphemus as a compatriot, is a poetic mode that makes an in-group of the Doric Sicilian out-group and an out-group of the Alexandrian in-group.

Elsewhere, the implication seems to be, the cosmopolis may dominate-but not here, not here in Theocritus' constructed locus amoenus. 


\section{Works Cited}

Aarne, A. and Thompson, S. 1961. The Types of the Folktale: A Classification and Bibliography. Helsinki.

Abbenes, Jelle G.J. 1996. "The Doric of Theocritus. A literary language.” In A. Harder, R. F. Regtuit and G. C. Wakker, edds. Theocritus. Hellenistica Groningana 2, 1-19. Groningen.

Adam, J. 1963. The Republic of Plato. Cambridge.

Ahrens, H. L. 1843. De Graecae linguae dialectis: De dialecto Dorica. (Vol. 2). Göttingen.

Alexandridou, A. 2011. The Early Black-figured Pottery of Attika in Context (c. 630-570 BCE). Monumenta Graeca et Romana, 17. Leiden.

Alexiou, M., Yatromanolakis, D. and Roilos, P. 2002. The Ritual Lament in Greek Tradition. $2^{\text {nd }}$ edn. Lanham, MD.

Alster, B. 1996. "Inanna Repenting: The Conlusion of Inanna's Descent." Acta Sumerologica 18: 1-18. Hiroshima.

Anagnostou-Laoutides, E. 2005. Eros and Ritual in Ancient Literature: Singing of Atalanta, Daphnis, and Orpheus. Piscataway, NJ.

Anagnostou-Laoutides, E. and Konstan, D. 2008. "Daphnis and Aphrodite : A Love Affair in Theocritus Idyll 1.” AJP 129: 497-527.

Anderson, G. 2006. Greek and Roman Folklore: A Handbook. Westport.

—. 2000. Fairytale in the Ancient World. London.

—. 1993. "The origins of Daphnis. Virgil's Eclogues and the ancient Near East." PVS 21: 65-79.

Antonaccio, C. 2003. "Hybridity and the Cultures within Greek Culture." In C. Dougherty and L. Kurke, eds. The Cultures within Greek Culture: Contact, Conflict, Collaboration, 5774. Cambridge.

—. 2001. "Ethnicity and Colonization." In I. Malkin, ed. Ancient Perceptions of Greek Ethnicity, 113-157. Cambridge, MA.

Appadurai, A. 1990. "Disjuncture and difference in the global cultural economy." Theory, Culture \& Society 7: 295-310.

Arnott, W. G. 1996. Alexis: The Fragments: A Commentary. Oxford. 
Austin, J. N. 1983. “Odysseus and the Cyclops: Who is Who?” In C. A. Rubino and C. W. Shelmerdine, eds. Approaches to Homer, 3-37. Austin.

Austin, C. and Bastianini, G. 2002. Posidippi Pellaei quae supersunt omnia. Milan.

Avlamis, P. 2010. “Aesopic Lives: Greek Imperial Literature and Urban Popular Culture.” PhD Dissertation, Princeton University.

Baron, C. 2012. Timaeus of Tauromenium and Hellenistic Historiography. Cambridge.

Baudy, G. "Agdistis." Brill's New Pauly. Antiquity volumes edited by: H. Cancik and H. Schneider. Brill Online, 2014. Reference. University of Virginia Library. 28 April 2014 <http://referenceworks.brillonline.com/entries/brill-s-new-pauly/agdistis-e107470>. First appeared online: 2006.

Baudy, G. 1993. "Hirtenmythos und Hirtenlied. Zu den rituellen Aspekten der bukolischen Dichtung." Poetica 25: 282-318.

Baumhauer, O. A. 2014. "Corax [3]." Brill's New Pauly. Antiquity volumes edited by: H. Cancik and H. Schneider. Brill Online, 2014. Reference. University of Virginia Library. 28 April 2014 <http://referenceworks.brillonline.com/entries/brill-s-new-pauly/corax-e620160>. First appeared online: 2006.

Bell III, M. 2011. "Agrarian Policy, Bucolic Poetry, and Figurative Art in Early Hellenistic Sicily." Krise und Wandel: Süditalien im 4. und 3. Jahrhundert v. Chr. Internationaler Kongress anlässlich des 65. Geburtstages von Dieter Mertens, Rom 26. bis 28. Juni 2006, 193-211.Wiesbaden.

Berg, W. 1974. Early Virgil. London.

Black, J.A., Cunningham, G., Ebeling, J., Flückiger-Hawker, E., Robson, E., Taylor, J., and Zólyomi, G. 1998-2006. The Electronic Text Corpus of Sumerian Literature (http://etcsl.orinst.ox.ac.uk/), Oxford.

Boardman, J. 1998. Early Greek Vase Painting. London.

- 1964. The Greeks Overseas: Their Early Colonies and Trade. $4^{\text {th }}$ edn. London.

—. 1963. "Artemis Orthia and Chronology." ABSA 58: 1-7.

Braccesi, L. 1994. Grecità di frontiera. Padua.

Bremmer, J. N. "Lityerses." Brill's New Pauly. Antiquity volumes edited by: H. Cancik and H. Schneider. Brill Online, 2014. Reference. University of Virginia Library. 28 April 2014 <http://referenceworks.brillonline.com/entries/brill-s-new-pauly/lityerses-e707930>. First appeared online: 2006. 
Bremmer, J. N. 2008. Greek Religion and Culture, the Bible, and the Ancient Near East. Leiden.

Brixhe, C. 2010. "Linguistic Diversity in Asia Minor during the Empire: Koine and Non-Greek Languages.” In E. Bakker, ed. A Companion to the Ancient Greek Language, 228-252. Chichester.

Buck, C. D. 1955. The Greek Dialects. Chicago. (Reprinted 1973).

Bulloch, A. W. 1985. Callimachus: The Fifth Hymn. Cambridge.

Burke, P. 1978. Popular Culture in Early Modern Europe. New York.

Burkert, W. 1985. Greek Religion. Trans. J. Raffan. Cambridge.

—. 1979. Structure and History in Greek Mythology and Ritual. Berkeley.

Burris, S. P. 2004. "Refrains in Ancient Greek Poetry,” PhD Dissertation, Cornell University.

Caberghs, I. 1944. "Commentaire des éléments folkloriques chez Théocrite," PhD Dissertation, Université de Louvain.

Calame, C. 1997. Choruses of Young Women in Ancient Greece: their Morphology, Religious Role, and Social Function. D. Collins, and J. Orion, trans. Lanham, MD.

Carter, J. B. 1987. "The Masks of Ortheia." AJA 91: 355-383.

—. 1986. "Masks and Poetry in Early Sparta." In R. Hagg, N. Marinatos, and G. Norquist, eds., Early Greek Cult Practice, Proceedings of the Fifth International Symposium of the Swedish Institute in Athens, 26-29 June, 1986, 89-98. Stockholm.

Cartledge, P. 1982. "Sparta and Samos: a Special Relationship?" CQ 32: 243-265.

-. 1979. Sparta and Lakonia: A Regional History 1300-362 BC. London.

Cassio, A. C. 1997. "Futuri dorici, dialetto di Siracusa e testo antico dei lirici greci." In Katà Diálekton: Atti del III Colloquio Internazionale di Dialettologia Greca. AION 19: 187214.

Caven, B. 1990. Dionysius: War Lord of Sicily. New Haven.

Chantraine, P. 1958. Grammaire homérique. Tome 1: Phonétique et morphologie. Paris.

—. 1926. Histoire du parfait Grec. Paris.

Cholmeley, R. J. 1919. Theocritus. London.

Christoforidou, M. 2005. "Mythological Figures in the Bucolic Idylls of Theocritus." MD 55: 3160. 
Cipolla, G. 1979. "Folk Elements in the Pastoral of Theocritus and Vergil." Journal of the University of Druban-Westville, 3, no. 2: 113-21.

Clarke, K. 2008. Making Time for the Past: Local History and the Polis. Oxford.

Clay, J. S. 1997. "The Homeric Hymns.” In I. Morris and B. Powell, eds. A New Companion to Homer, 463-488. Leiden.

Clarysse, W. 1998. "Ethnic Diversity and Dialect among the Greeks of Hellenistic Egypt." In A. M. F. W. Verhoogt and S. P. Vleeming, eds. The Two Faces of Graeco-Roman Egypt, 113. Leiden.

Cohen, M. E. 1988. The Canonical Lamentations of Ancient Mesopotamia. Potomac, MD.

Cole, T. 1991. The Origins of Rhetoric in Ancient Greece. Baltimore.

Colvin, S. 2007. A Historical Greek Reader: Mycenaean to the Koiné. Oxford.

Consigny, S. C. 2001. Gorgias: Sophist and Artist. Columbia, S. C.

Cook, B. F. 1984. "Aristaios I." LIMC II.1: 603-607. Zurich.

Crane, G. 1988. "Realism in the Fifth Idyll of Theocritus." TAPA 118: 107-122.

Cunningham, I. C. 1971. Herodas: Mimiambi. Oxford.

Cusset, C. 2011. Cyclopodie: édition critique et commentée de l'Idylle VI de Théocrite. Lyon.

Dalby, A. 1996. Siren Feasts: A History of Food and Gastronomy in Greece. New York.

Dalley, S. 2008. Myths from Mesopotamia: Creation, the Flood, Gilgamesh, and Others. Oxford.

Dawkins, R. M. 1929. “The History of the Sanctuary.” In R. M. Dawkins, ed. The Sanctuary of Artemis Orthia at Sparta: The Society for the Promotion of Hellenic Studies, Supplementary Paper n. 5, 1-51. London.

Des Bouvrie, S. 2009. “Artemis Ortheia: A Goddess of Nature or a Goddess of Culture.” In T. Fischer-Hansen and B. Poulsen, eds. From Artemis to Diana: The Goddess of Man and Beast. Acta Hyperborea 12, 153-190. Copenhagen.

Diels, H., and Kranz, W. 1951. Die Fragmente der Vorsokratiker, I-III. $6^{\text {th }}$ edn. Berlin.

Di Mino, C. 1931. "Il folklore siciliano di Teocrito.” Folklore italiano 6: 217-259.

Dover, K. J. 1971. Theocritus: Select Poems. London. 
Dubois, L. 1989. Inscriptions grecques dialectales de Sicile: contribution à l'étude du vocabulaire grec colonial. (Vol. II). Rome.

Duncan, A. 2012. "A Theseus outside Athens: Dionysius I of Syracuse and tragic selfpresentation." In K. Bosher, ed. Theater Outside Athens: Drama in Greek Sicily and Magna Graecia, 137-155. Cambridge.

Edmunds, L. 1997. "Myth in Homer." In I. Morris and B. Powell, eds. A New Companion to Homer, 415-441. Leiden.

Falb, D. Z. K. 2009. "Das Artemis Orthia-Heiligtum in Sparta im 7. und 6. Jh.v.Chr." In T. Fischer-Hansen and B. Poulsen, eds. From Artemis to Diana: The Goddess of Man and Beast. Acta Hyperborea 12, 127-152. Copenhagen.

Fantuzzi, M. "Bucolics [I]." Brill's New Pauly. Antiquity volumes edited by: H. Cancik and H. Schneider. Brill Online, 2014. Reference. University of Virginia Library. 28 April 2014 $<$ http://referenceworks.brillonline.com/entries/brill-s-new-pauly/bucolics-e221280>. First appeared online: 2006.

Fantuzzi, M. and Hunter, R.. 2004. Tradition and Innovation in Hellenistic Poetry. Cambridge.

Faulkner, A., ed. 2008. The Homeric Hymn to Aphrodite: Introduction, Text, and Commentary. Oxford.

Fitzhardinge, L. F. 1980. The Spartans. London.

Frazer, J. G. 1989. Apollodorus: The Library. (2 vols.). Cambridge, MA.

Frede, M. "Archytas [2] Ps.-Archytas." Brill's New Pauly. Antiquity volumes edited by: H. Cancik and H. Schneider. Brill Online, 2014. Reference. University of Virginia Library. 28 April $2014<\mathrm{http}: / /$ referenceworks.brillonline.com/entries/brill-s-new-pauly/archytase133040>. First appeared online: 2006.

Frontisi-Ducroux, F. 1995. Du masque au visage: aspects de l'identité en Grèce ancienne. Paris.

Glenn, J. 1978. “The Polyphemus Myth: Its Origin and Interpretation.” Greece \& Rome 25: 141155.

Goldhill, Simon. 2010. "What is local identity? The politics of cultural mapping." In T. Whitmarsh, ed. . Local Knowledge and Microidentities in the Imperial Greek World, 4668. Cambridge.

Gottschalk, Hans. "Phaenias." Brill's New Pauly. Antiquity volumes edited by: H. Cancik and H. Schneider. Brill Online, 2014.Reference. University of Virginia Library. 28 April 2014 
<http://referenceworks.brillonline.com/entries/brill-s-new-pauly/phaenias-e917630>. First appeared online: 2006.

Gow, A. S. F., ed. 1952. Theocritus. (2 vols.). Cambridge.

Gow, A. S. F. and Page, D. L. eds. 1965. The Greek Anthology: Hellenistic Epigrams. Cambridge.

Graf, F. "Anchises." Brill's New Pauly. Antiquity volumes edited by: H. Cancik and H. Schneider. Brill Online, 2014. Reference. University of Virginia Library. 28 April 2014 <http://referenceworks.brillonline.com/entries/brill-s-new-pauly/anchises-e120840>. First appeared online: 2006.

Graziosi, Barbara. 2002. Inventing Homer: The Early Reception of Epic. Cambridge.

Griffin, Jasper. 1992. "Theocritus, the Iliad, and the East." AJP 113: 189-211.

Green, P., ed. 1993. Hellenistic History and Culture. Berkeley.

—. 1990. Alexander to Actium: the Historical Evolution of the Hellenistic Age. Berkeley.

Gruen, E. 1984. The Hellenistic World and the Coming of Rome (2 vols.). Berkeley.

Gulick, C. B. 1950. Athenaeus: The Deipnosophists. Vol 6: Book XIII-Book XIV. Cambridge.

Gutzwiller, K. J. 1991. Theocritus'Pastoral Analogies: The Formation of a Genre. Madison.

Guzzetta, G. "Acrae." Brill's New Pauly. Antiquity volumes edited by: H. Cancik and H.

Schneider. Brill Online, 2014. Reference. University of Virginia Library. 28 April 2014 <http://referenceworks.brillonline.com/entries/brill-s-new-pauly/acrae-e112070>. First appeared online: 2006.

Hackman, O. 1904. Die Polyphemsage in der Volksüberlieferung. Helsinki.

Hadley, J. M. 2000. The Cult of Asherah in Ancient Israel and Judah. Cambridge.

Hainsworth, J. B. 1988. "The Epic Dialect.” In A. Heubeck, S. West and J. B. Hainsworth, A Commentary on Homer's Odyssey: Vol. I: Introduction and Books I-VIII, 24-32. Oxford.

Hall, J. M. 2007. A History of the Archaic Greek World. Malden, MA.

—. 1997. Ethnic Identity in Greek Antiquity. Cambridge.

Hallo, W. W. and Younger, K. L. eds. 2003. The Context of Scripture. Leiden.

Halperin, D. M. 1983(a). "The Forebears of Daphnis." TAPA 113: 183-200. 
—. 1983(b). Before Pastoral: Theocritus and the Ancient Tradition of Bucolic Poetry. New Haven.

Hannerz, U. 1990. "Cosmopolitans and locals in world culture." Theory, Culture \& Society 7: 237-251.

Hansen, W. F. 2002. Ariadne's Thread: A Guide to International Tales found in Classical Literature. Ithaca.

Harder, A. 2011. Callimachus, Aetia. Vol. 1: Introduction, Text and Translation. Vol. 2: Commentary. Oxford.

Heubeck, A. and Hoekstra, A. 1989. A Commentary on Homer's Odyssey. Vol. 2, Books IX-XVI. Oxford.

Heubeck, A., West, S. and Hainsworth, J. B. 1988. A Commentary on Homer's Odyssey. Vol. I: Introduction and Books I-VIII. Oxford.

Hilgard, A. 1887. Excerpta ex libris Herodiani technici. Leipzig.

Hodos, T. 2006. Local Responses to Colonization in the Iron Age Mediterranean. London.

Höghammar, K., ed. 2004. The Hellenistic Polis of Kos: State, Economy and Culture : Proceedings of an International Seminar Organized by the Department of Archaeology and Ancient History, Uppsala University, 11-13 May, 2000. Uppsala.

Holland, G. R. 1884. De Polyphemo et Galatea. Leipzig.

Hopkinson, N. 1984. Callimachus: Hymn to Demeter. Cambridge.

Hordern, J. H. 2004. “Cyclopea. Philoxenus, Theocritus, Callimachus, Bion.” CQ 54: 285-92.

—. 1999. "The Cyclops of Philoxenus." CQ 49: 445-55.

Horowski, J. 1973. “Le folklore dans les idylls de Théocrite.” Eos 61: 187-212.

Horrocks, G. 2010. Greek: A History of the Language and its Speakers. Chichester.

—. 1997. "Homer's Dialect." In I. Morris and B. Powell, eds. A New Companion to Homer, 193217. Leiden.

Hunter, R. "Theocritus [2]." Brill's New Pauly. Antiquity volumes edited by: H. Cancik and H. Schneider. Brill Online, 2014. Reference. University of Virginia Library. 28 April 2014 <http://referenceworks.brillonline.com/entries/brill-s-new-pauly/theocritus-e1209080〉. First appeared online: 2006. 
Hunter, R. 2005(a). "Literature and its Contexts." In Andrew Erskine, ed. A Companion to the Hellenistic World, 477-493. Malden, MA.

—. 2005(b). "Speaking in glossai. Dialect choice and cultural poetics in Hellenistic Poetry." In W.M. Bloomer ed. The Contest of Language. Before and Beyond Nationalism, 187-242. Notre Dame.

—. 2004. "Homer and Greek Literature." In R. L. Fowler, ed. The Cambridge Companion to Homer, 235-253. Cambridge.

—., ed. 2003. Theocritus: Encomium of Ptolemy Philadelphus. Berkeley.

—., ed. 1999. Theocritus: A Selection. Cambridge.

—. 1996. Theocritus and the Archaeology of Greek Poetry. Cambridge.

—., ed. 1983. Eubulus: The Fragments. Cambridge.

Jacobsen, T. 1987. The Harps that once--: Sumerian Poetry in Translation. New Haven.

—. 1976. Treasures of Darkness: A History of Mesopotamian Religion. New Haven.

- 1970. Toward the Image of Tammuz and Other Essays on Mesopotamian History and Culture. Harvard Semitic Studies 21. Cambridge.

Jacoby, F. 1923-1958. Die Fragmente der griechischen Historiker, I-III. Leiden.

Janko, R. 1992. The Iliad: A Commentary: Volume IV: Books 13-16. Cambridge.

Jones, H. L., trans. 1969. The Geography of Strabo. Cambridge.

—, trans. 1966. Pausanias: Description of Greece. Cambridge.

Kaibel, G. 1899. Comicorum Graecorum fragmenta. Berlin.

Kassel, R. and Austin, C. 1984-. Poetae comici Graeci. Berlin.

Kennedy, G. A. 1994. A New History of Classical Rhetoric. Princeton.

Kennel, N. M. 1995. The Gymnasium of Virtue: Education and Culture in Ancient Sparta. Chapel Hill.

Kolde, A. 2003. Politique et Religion chez Isyllos d'Epidaure. Basel.

Kostopoulou, V. 2007. "Polyphemus and Galatea: Variations on a Theme." PhD Dissertation, University of Wisconsin, Madison.

Kovacs, D. 1994. Euripides: Volume 1. Cambridge, Mass. 
Kowalzig, B. "Orthia." Brill's New Pauly. Antiquity volumes edited by: H. Cancik and H. Schneider. Brill Online, 2014.Reference. University of Virginia Library. 28 April 2014 <http://referenceworks.brillonline.com/entries/brill-s-new-pauly/orthia-e901650>. First appeared online: 2006.

Krevans, N. and Sens, A. 2006. "Language and literature." In Glenn R. Bugh ed. The Cambridge Companion to the Hellenistic World. Cambridge.

Kunz, H. 2014. "Sicily: VII. Religion." Brill's New Pauly. Antiquity volumes edited by: H. Cancik and H. Schneider. Brill Online, 2014. Reference. University of Virginia Library. 28 April 2014 <http://referenceworks.brillonline.com/entries/brill-s-new-pauly/sicilye1111770>. First appeared online: 2006.

Kurke, L. 2011. Aesopic Conversations: Popular Tradition, Cultural Dialogue, and the Invention of Greek Prose. Princeton.

Lambin, G. 1992. La chanson grecque dans l'Antiquité. Paris.

Larson, J. 2007. Ancient Greek Cults: A Guide. New York.

—. 2001. Greek Nymphs: Myth, Cult, Lore. Oxford.

Lawall, G. 1967. Theocritus' Coan Pastorals; a Poetry Book. Washington.

Lee, I. 1999. "The Flower of Adonis at Eryx." Numismatic Chronicle 159: 1-31.

Leick, G. 1994. Sex and eroticism in Mesopotamian literature. London.

Lipiński, E. 1995. Dieux et déesses de l'univers phénicien et punique. Leuven.

Lipinski, E., Baurain, C., Bonnet, et al., eds. 1993. Dictionnaire de la civilisation phénicienne et punique. Turnhout.

Livingstone, A. 1989. Court Poetry and Literary Miscellanea. Helsinki.

Lloyd-Jones, H. and Parsons, P. 1983. Supplementum Hellenisticum. Berlin.

Lo Porto, F. G. 1967. “Tombe di atleti tarentini." ASMG 8: 31-98.

Lowenstam, A. 2008. As Witnessed by Images: The Trojan War in Greek and Etruscan Art. Baltimore.

Luraghi, N. 2008. The Ancient Messenians: Constructions of Ethnicity and Memory. Cambridge. MacInnes, D. and Trübner Nutt, A. 1890. Folk and Hero Tales. London. 
Magnien, V. 1920. "Le syracusain littéraire et l'Idylle XV de Théocrite." Mém. Soc. Ling. 21: 112-138.

—. 1912. Le Futur Grec. Vol. 1. Paris.

Malkin, I. 2011. A Small Greek World: Networks in the Ancient Mediterranean. Oxford.

—. 1998. The Returns of Odysseus: Colonization and Ethnicity. Berkeley.

-. 1994. Myth and Territory in the Spartan Mediterranean. Cambridge.

—. 1987. Religion and Colonization in Ancient Greece. Leiden.

Marangou, L. 1972. "Aristaios." AM 87: 77-83.

Markoe, G. 2000. Phoenicians. Berkeley.

—. 1985. Phoenician Bronze and Silver Bowls from Cyprus and the Mediterranean. Berkeley.

Marsman, H. J. 2003. Women in Ugarit and Israel: their Social and Religious Position in the Context of the Ancient Near East. Leiden.

Massimilla, G. ed. 1996. Aitia: Libri Primo e Secondo. Pisa.

Meister, K. 2014. "Timaeus [2]." Brill's New Pauly. Antiquity volumes edited by: H. Cancik and H. Schneider. Brill Online, 2014. Reference. University of Virginia Library. 28 April $2014<$ http://referenceworks.brillonline.com/entries/brill-s-new-pauly/timaeuse1214360>. First appeared online: 2006.

Mejer, J. 2009. "Artemis in Athens." In T. Fischer-Hansen and B. Poulsen, eds. From Artemis to Diana: The Goddess of Man and Beast. Acta Hyperborea 12, 127-152. Copenhagen.

Méndez Dosuna, J. 2007. “The Doric Dialects.” In A.-F. Christidis, ed. A History of Ancient Greek: From the Beginnings to Late Antiquity, 444-459. Cambridge.

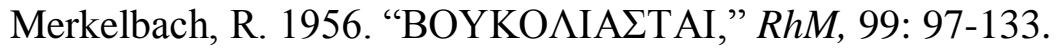

Mettinger, T. N. D. 2001. The Riddle of Resurrection: Dying and Rising Gods in the Ancient Near East. Coniectanea Biblica, Old Testament Series 50. Stockholm.

Mimbrera, S. 2012. "The Sicilian Doric koina." In O. Tribulato, ed. Sikelia: Multilingualism and Cultural Interaction in Ancient Sicily, 223-250. Cambridge.

Molinos Tejada, M-T. 1990. Los Dorismos del Corpus Bucolicorum. Amsterdam. 
Monoson, S. S. 2012. "Dionysius I and Sicilian theatrical traditions in Plato's Republic: representing continuities between democracy and tyranny." In K. Bosher, ed. Theater Outside Athens: Drama in Greek Sicily and Magna Graecia, 156-174. Cambridge.

Monro, D. B. 1891. Homeric Grammar. Oxford. (Reprinted London, 1998).

Moretti, L. 1984. 'Epigramma per un atleta di Taranto, III.” In G. Barone, E. Epifanio Vanni, N. Bonacasa, A. Di Vita, eds. Alessandria e il mondo ellenistico-romano. Studi in onore di A. Adriani, vol. III, 495-497. Rome.

Morpurgo Davies, A. 1964. “"Doric' Features in the Language of Hesiod.” Glotta 43: 138-165.

Mugler, C. 1971. Archimède: Vol. 3. Paris.

Müller, H.-P. "Tinnit." Brill's New Pauly. Antiquity volumes edited by: H. Cancik and H. Schneider. Brill Online, 2014. Reference. University of Virginia Library. 28 April 2014 <http://referenceworks.brillonline.com/entries/brill-s-new-pauly/tinnit-e1215430>. First appeared online: 2006.

Müller, K. 1841-1891. Fragmenta historicorum Graecorum (FHG) 4. Paris.

Nagy, G. 2010. Homer the Preclassic. Berkeley.

-. 1979. The Best of the Achaeans: Concepts of the Hero in Archaic Greek Poetry. Baltimore.

Nauck, A. ed. 1889. Tragicorum Graecorum Fragmenta. Leipzig.

Niehr, H. "Baal." Brill's New Pauly. Antiquity volumes edited by: H. Cancik and H. Schneider. Brill Online, 2014. Reference. University of Virginia Library. 28 April 2014 <http://referenceworks.brillonline.com/entries/brill-s-new-pauly/baal-e210930>. First appeared online: 2006.

Nippel, W. 2002. "The Construction of the 'Other."' In T. Harrison, ed. Greeks and Barbarians, 278-310. New York.

Nisetich, F. J. 2005. 'The poems of Posidippus. Translation.' In: K. J. Gutzwiller, ed. The New Posidipppus: A Hellenistic Poetry Book, 17-64. Oxford.

Olshausen, E. "Tyndaris." Brill's New Pauly. Antiquity volumes edited by: H. Cancik and H. Schneider. Brill Online, 2014. Reference. University of Virginia Library. 28 April 2014 <http://referenceworks.brillonline.com/entries/brill-s-new-pauly/tyndaris-e1223630>. First appeared online: 2006.

Olson, S. D. 2007. Broken Laughter: Select Fragments of Greek Comedy. Oxford.

—. 2002. Aristophanes: Acharnians. Oxford. 
Olson, S. D. and Sens, A. 2000. Archestratus of Gela: Greek Culture and Cuisine in the $4^{\text {th }}$ Century BCE: Text, Translation, and Commentary. Oxford.

O’Neill Jr., E. trans. 1938. Aristophanes. Birds. The Complete Greek Drama, vol. 2. New York.

Page, D. L. ed. 1962. Poetae melici Graeci. Oxford.

—. 1951. Alcman: The Parthenion. Oxford.

Payne, M. 2010. "The Bucolic Fiction of Theocritus.” In J. J. Clauss and M. Cuypers, eds. A Companion to Hellenistic Literature, 224-237. Chichester.

Penglase, C. 1994. Greek myths and Mesopotamia: Parallels and Influence in the Homeric Hymns and Hesiod. London.

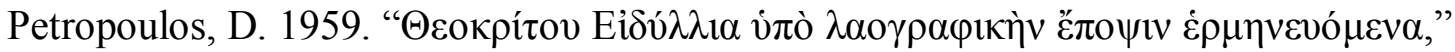

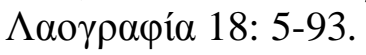

Pettersson, M. 1992. Cults of Apollo at Sparta: the Hyakinthia, the Gymnopaidiai and the Karneia. Skrifter utgivna av Svenska institutet i Athen = Acta Instituti Atheniensis Regni Sueciae Stockholm 8: 12. Stockholm.

Pettey, R. J. 1990. Asherah: Goddess of Israel. American University Studies, Series VII (Theology and Religion), Vol. 74. New York.

Pfeiffer, R. 1949. Callimachus. (2 vols.). Oxford.

Pipili, M.. 1987. Laconian Iconography of the Sixth Century B.C. Oxford.

Pitrè, G., Zipes J. D, and Russo, J. 2009. The Collected Sicilian Folk and Fairy Tales of Giuseppe Pitrè. New York.

Positano, L. M. and Koster, W. J. W. 1960. Scholia in Aristophanem. Pars 4, Jo. Tzetzae commentarii in Aristophanem / Fasc.1, Prolegomena et Commentarium in Plutum. Groningen.

Redfield, R. 1956. Peasant Society and Culture: an Anthropological Approach to Civilization. Chicago.

Reece, S. 1993. The Stranger's Welcome: Oral Theory and the Aesthetics of the Homeric Hospitality Scene. Ann Arbor.

Robbins, E. "Erinna." Brill's New Pauly. Antiquity volumes edited by: H. Cancik and H. Schneider. Brill Online, 2014. Reference. University of Virginia Library. 28 April 2014 
<http://referenceworks.brillonline.com/entries/brill-s-new-pauly/erinna-e401510>. First appeared online: 2006.

Roller, L. E. 1999. In Search of God the Mother: the Cult of Anatolian Cybele. Berkeley.

Rose, H. J. 1929. “The Cult of Artemis Orthia.” In R. M. Dawkins, ed. The Sanctuary of Artemis Orthia at Sparta: The Society for the Promotion of Hellenic Studies, Supplementary Paper n. 5, 399-407. London.

Rosen, R. M. 2007. Making Mockery: The Poetics of Ancient Satire. Oxford.

—. 1997. "Homer and Hesiod." In I. Morris and B. Powell, eds. A New Companion to Homer, 463-488. Leiden.

Rosenmeyer, T. G. 1969. The Green Cabinet; Theocritus and the European Pastoral Lyric. Berkeley.

Ruina, D. T. 2014. “Diogenes [17].” Brill's New Pauly. Antiquity volumes edited by: H. Cancik and H. Schneider. Brill Online, 2014. Reference. University of Virginia Library. 28 April $2014<$ http://referenceworks.brillonline.com/entries/brill-s-new-pauly/diogenese318510>. First appeared online: 2006.

Ruijgh, C. J. 1991. “Le dorien de Théocrite: dialecte cyrénien d'Alexandrie et d'Égypte.” In J. M. Bremer, A. Rijksbaron and F. M. J. Waanders, eds. Scripta minora ad linguam Graecam pertinentia, 405-437. Amsterdam. [=Ruijgh, C. J. 1984. "Le dorien de Théocrite. Dialecte cyrénien d'Alexandrie et d'Égypte.” Mnemosyne 37: 56-88].

Salsano, D. "Nacone." Brill's New Pauly. Antiquity volumes edited by: H. Cancik and H. Schneider. Brill Online, 2014. Reference. University of Virginia Library. 28 April 2014 <http://referenceworks.brillonline.com/entries/brill-s-new-pauly/nacone-e816520>. First appeared online: 2006.

Sanders, L. J. 1987. Dionysius I of Syracuse and Greek Tyranny. New York.

Sefati, Y. 1990. "An Oath of Chastity in a Sumerian Love Song (SRT 31)?" In J. Klein and A. Skaist, eds. Bar-Ilan Studies in Assyriology, 45-63. Ramat Gan.

- 1998. Love Songs in Sumerian Literature: Critical Edition of the Dumuzi-Inana Songs. Ramat Gan.

Segal, C. 1981. Poetry and Myth in Ancient Pastoral: Essays on Theocritus and Virgil. Princeton.

—. 1969. "Adonis and Aphrodite: Theocritus, Idyll III, 48." AC 38: 82-88. 
Segre, M. 1993. Iscrizioni di Cos. Monografie della Scuola Archeologica di Atene e delle Missioni Italiane in Oriente, 6. Rome.

Selden, D. L. 1998. "Alibis." ClAnt 17: 289-412.

Sens, A. 2004. "Doricisms in the New and Old Posidippus." In B. Acosta-Hughes, M. Baumbach and E. Kosmetatou, eds. Labored in Papyrus Leaves : Perspectives on an Epigram Collection Attributed to Posidippus (P.Mil.Vogl. VIII 309), 65-83. Washington, D.C.

-. 2003. Review of Spanoudakis (2002). BMCR 2003.02.38. http://bmcr.brynmawr.edu/2003/2003-02-38.html. (accessed April 23, 2014).

Sfameni Gasparro, G. 1973. I culti orientali in Sicilia. Leiden.

Sherwin-White, S. M. 1978. Ancient Cos: An Historical Study from the Dorian Settlement to the Imperial Period. Hypomnemata 51. Göttingen.

Sihler, A. L. 1995. New Comparative Grammar of Greek and Latin. Oxford.

Simon, E. 1995. "Early Images of Daidalos in Flight." In J. B. Carter and S. P. Morris, eds. The Ages of Homer: A Tribute to Emily Townsend Vermeule, 407-414. Austin.

Smith, J. Z. 1987. "Dying and Rising Gods," Encyclopedia of Religion 4: 521-27. New York.

Smith, M. S. 2001. The Origins of Biblical Monotheism: Israel's Polytheistic Background and the Ugaritic Texts. Oxford.

Smith, M. S., and Pitard, W. T. 1994-2009. The Ugaritic Baal Cycle. (2 vols.). Leiden.

Smith, T. J. 2010. Komast Dancers in Archaic Greek Art. Oxford.

Snell, B., Kannicht, R. and Radt, S. eds. 1971-. Tragicorum Graecorum fragmenta. Göttingen.

Snodgrass, A. 1998. Homer and the Artists: Text and Picture in Early Greek Art. Cambridge.

Sourvinou-Inwood, C. 2005. Hylas, the Nymphs, Dionysos and Others: Myth, Ritual, Ethnicity. Stockholm.

—. 2000. "What is Polis Religion?" In R. Buxton, ed. Oxford Readings in Greek Religion, 13-37. Oxford.

Spanoudakis, K. 2002. Philitas of Cos. Leiden.

Storey, J. 2003. Inventing Popular Culture: from Folklore to Globalization. Malden, MA.

Stuckey, J. H. 2003. "The Great Goddesses of the Levant." JSSEA 30: 127-157. 
Teixidor, J. 1980. "L'assemblée législative en Phénicie d'après les inscriptions." Syria 57: 453464.

Thesleff, H. 1965. The Pythagorean texts of the Hellenistic period. Abo.

Thomas, R. S. 1971. "Polyphemus in Art and Literature." PhD Dissertation, Tufts University.

Thompson, S. 1955. Motif-Index of Folk-Literature: A Classification of Narrative Elements in Folktales, Ballads, Myths, Fables, Mediaeval Romances, Exempla, Fabliaux, Jest-Books, and Local Legends. Bloomington.

Touchefeu-Meynier, O. 1997. "Polyphemos I." LIMC VIII.1: 1011-1019. Zurich.

Tovar, S. T. 2010. “Greeks in Egypt.” In E. Bakker, ed. A Companion to the Ancient Greek Lanugage, 253-266. Chichester.

Troxler, H. 1964. "Sprache und Wortschatz Hesiods.” PhD Dissertation, Zürich.

Wace, A. J. B. 1929. "The Lead Figurines." In R. M. Dawkins, ed. The Sanctuary of Artemis Orthia at Sparta: The Society for the Promotion of Hellenic Studies, Supplementary Paper n. 5, 249-284. London.

Walde, C. "Rhetoric [I-V].” Brill's New Pauly. Antiquity volumes edited by: Hubert Cancik and , Helmuth Schneider. Brill Online, 2014. Reference. University of Virginia Library. 28 April 2014 <http://referenceworks.brillonline.com/entries/brill-s-new-pauly/rhetorice1022090>. First appeared online: 2006.

Webster, T. B. L. 1970. Studies in Later Greek Comedy. Manchester.

Wehrli, F. 1969. Die Schule des Aristoteles, Vol 9: Texte und Kommentar: Phainias von Eresos. Chamaileon. Praxiphanes. Basel.

Wendel, C., ed. 1914. Scholia in Theocritum Vetera. Leipzig.

West, M. L. 1997. The East Face of Helicon. West Asiatic Elements in Greek Poetry. Oxford.

Whitmarsh, T. 2010. “Thinking Local.” In T. Whitmarsh, ed. Local Knowledge and Microidentities in the Imperial Greek World, 1-16. Cambridge.

Wiles, D. 2007. Mask and Performance in Greek Tragedy: From Ancient Festival to Modern Experimentation. Cambridge.

Wilkins, J. 2000. The Boastful Chef: The Discourse of Food in Greek Antiquity. Oxford. 
Willi, A. 2012. “'We speak Peloponnesian': Tradition and linguistic identity in postclassical Sicilian literature.” In O. Tribulato, ed. Sikelia: Multilingualism and Cultural Interaction in Ancient Sicily, 265-288. Cambridge.

—. 2008. Sikelismos : Sprache, Literatur und Gesellschaft im griechischen Sizilien (8.-5. Jh.v. Chr.). Basel.

Woodward, A. M. 1929. "Inscriptions.” In R. M. Dawkins, ed. The Sanctuary of Artemis Orthia at Sparta: The Society for the Promotion of Hellenic Studies, Supplementary Paper n. 5, 285-377. London.

Wyatt, N. 2002. Religious Texts from Ugarit. London.

Wyatt, W. F. 1966. "Short Accusative Plurals in Greek.” TAPA 97: 617-643.

Yonge, C. D. trans. 1853-1854. Deipnosophists of Athenaeus. London. 